Re-conceptualising Territorial Cohesion Through the Prism of Spatial Justice : Critical Perspectives on Academic and Policy Discourses

\title{
Jones, Rhys
}

Palgrave Macmillan

2019-01-24

Jones , R , Moisio , S M , Weckroth , M T K, Luukkonen , J M , Mayer , F \& Miggelbrink , J 2019 , Re-conceptualising Territorial Cohesion Through the Prism of Spatial Justice : Critical Perspectives on Academic and Policy Discourses . in T Lang \& F Görmar (eds), Regional and local development in times of polarisation: Re-thinking spatial policies in Europe ., 5 , Palgrave Macmillan , Singapore , pp. 97-120 . https://doi.org/10.1007/978-981-13-1190-1

http://hdl.handle.net/10138/298718

https://doi.org/10.1007/978-981-13-1190-1

cc_by

publishedVersion

Downloaded from Helda, University of Helsinki institutional repository.

This is an electronic reprint of the original article.

This reprint may differ from the original in pagination and typographic detail.

Please cite the original version. 

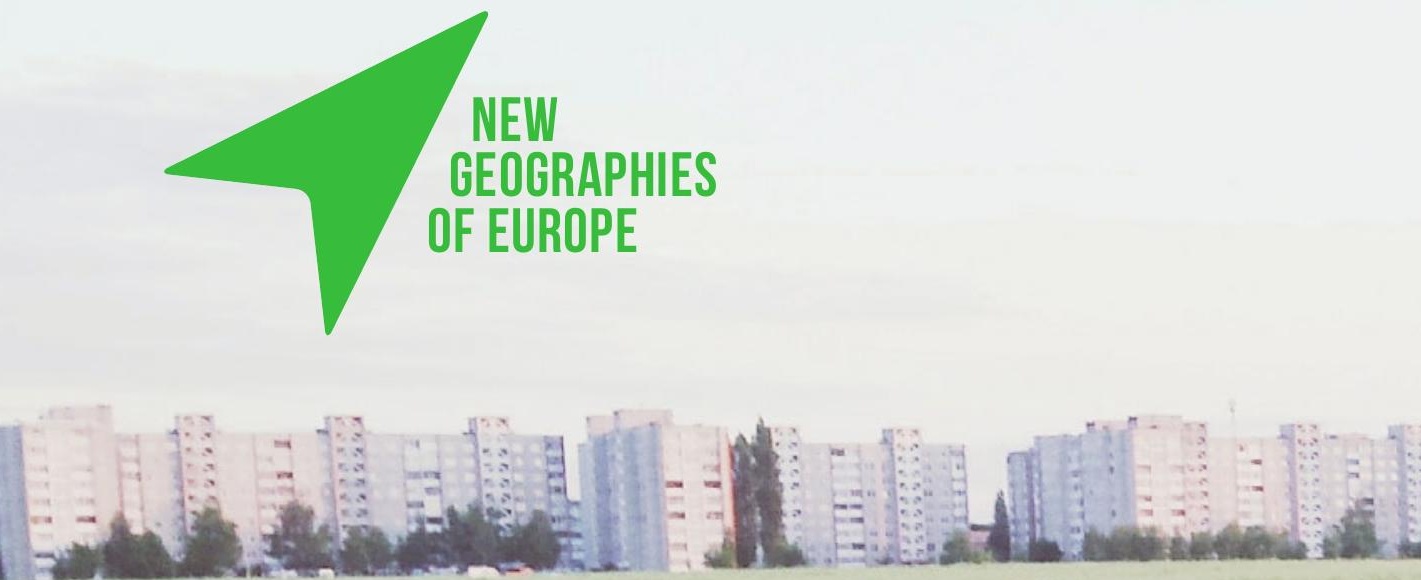

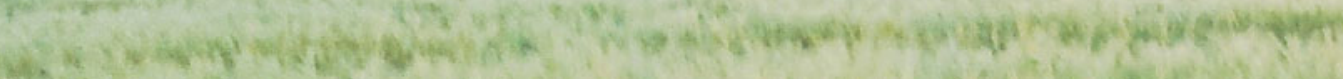
27.

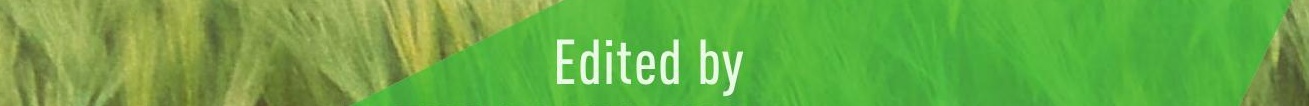
, 8 THLLO LANG AND
FRANZISKA GÖRMAR

REGIONAL AND LOCAL DEVELOPMENT IN TIMES OF POLARISATION

Re-Thinking Spatial Policies in Europe

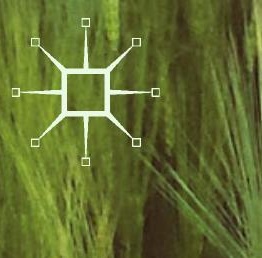




\title{
New Geographies of Europe
}

\author{
Series Editors \\ Sebastian Henn \\ Friedrich-Schiller-Universität Jena \\ Jena, Germany \\ Ray Hudson \\ Durham University \\ Durham, UK \\ Thilo Lang \\ Leibniz Institute for Regional Geography \\ University of Leipzig \\ Leipzig, Germany \\ Judit Timár \\ Hungarian Academy of Sciences \\ Budapest, Hungary
}


This series explores the production and reshaping of space from a comparative and interdisciplinary perspective. By drawing on contemporary research from across the social sciences, it offers novel insights into ongoing spatial developments within and between the various regions of Europe. It also seeks to introduce new geographies at the edges of the European Union and the interplay with bordering areas at the Mediterranean, African and eastern Asian interfaces of the EU. As a result, this series acts as an important forum for themes of pan-European interest and beyond. The New Geographies of Europe series welcomes proposals for monographs and edited volumes taking a comparative and interdisciplinary approach to spatial phenomena in Europe. Contributions are especially welcome where the focus is upon novel spatial phenomena, path-dependent processes of socio-economic change or policy responses at various levels throughout Europe. Suggestions for topics also include the relationship between the state and citizens, the idea of fragile democracies, the economics of regional separation, the deconstruction of the idea of Europe, the comparative assessment of European planning models, new migration streams, and the European labour market.

More information about this series at http://www.palgrave.com/gp/series/14740 
Thilo Lang · Franziska Görmar Editors

Regional and Local Development in

Times of Polarisation

Re-thinking Spatial Policies in Europe

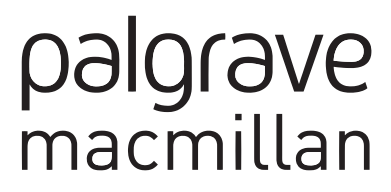


Editors

Thilo Lang

Global and European Studies Institute

University of Leipzig

Leipzig, Germany

and

Leibniz Institute for Regional Geography

University of Leipzig

Leipzig, Germany
Franziska Görmar

Leibniz Institute for Regional Geography

University of Leipzig

Leipzig, Germany

\section{(c) (1)}

New Geographies of Europe

ISBN 978-981-13-1189-5

https://doi.org/10.1007/978-981-13-1190-1

ISBN 978-981-13-1190-1 (eBook)

Library of Congress Control Number: 2018946622

(C) The Editor(s) (if applicable) and The Author(s) 2019. This book is an open access publication.

Open Access This book is licensed under the terms of the Creative Commons Attribution 4.0 International License (http://creativecommons.org/licenses/by/4.0/), which permits use, sharing, adaptation, distribution and reproduction in any medium or format, as long as you give appropriate credit to the original author(s) and the source, provide a link to the Creative Commons license and indicate if changes were made.

The images or other third party material in this book are included in the book's Creative Commons license, unless indicated otherwise in a credit line to the material. If material is not included in the book's Creative Commons license and your intended use is not permitted by statutory regulation or exceeds the permitted use, you will need to obtain permission directly from the copyright holder.

The use of general descriptive names, registered names, trademarks, service marks, etc. in this publication does not imply, even in the absence of a specific statement, that such names are exempt from the relevant protective laws and regulations and therefore free for general use.

The publisher, the authors, and the editors are safe to assume that the advice and information in this book are believed to be true and accurate at the date of publication. Neither the publisher nor the authors or the editors give a warranty, express or implied, with respect to the material contained herein or for any errors or omissions that may have been made. The publisher remains neutral with regard to jurisdictional claims in published maps and institutional affiliations.

Cover credit: Alexander Kovalevich/EyeEm

This Palgrave Macmillan imprint is published by the registered company Springer Nature Singapore Pte Ltd.

The registered company address is: 152 Beach Road, \#21-01/04 Gateway East, Singapore 189721, Singapore 


\section{Acknowledgements}

This book is fuelled by long-standing research collaborations focusing on socio-spatial polarisation in Europe. It combines conceptual thoughts and empirical observations gained through joint project work in the Marie Curie Initial Training Network 'Socio-economic and Political Responses to Regional Polarisation in Central and Eastern Europe' $\left(\mathrm{RegPol}^{2}\right)$. This project was funded by the European Union through the 7th Framework Programme under grant agreement no. 607022 and coordinated by the Leibniz Institute for Regional Geography (IfL) in Leipzig, Germany. We are deeply indebted to all junior and senior researchers who took part in the project for their valuable work and the fantastic time we had together. We also thank all visiting researchers and practitioners who shared their knowledge and experiences with us during this time and provided valuable inputs in a number of workshops and conferences between 2014 and 2017.

We most warmly thank all authors and reviewers who have contributed to this book with their great expertise. We extend our thanks to the administration staff of IfL (especially Franziska Weyrich for her support in financial issues) and Stefan Haunstein, research assistant at the 
institute, who have shown great commitment in realising this endeavour. We also thank the editing team at Palgrave Macmillan and the publishing house in general, which was willing to accept our book in the series on New Geographies of Europe. 


\section{Contents}

1 Re-thinking Regional and Local Policies in Times of Polarisation: An Introduction

Franziska Görmar, Thilo Lang, Erika Nagy

and Garri Raagmaa

Part I Socio-Spatial Polarisation in the EU and Questions of Power

2 Geographical Uneven Development and Regional Futures: A Conversation

Ray Hudson and John Pickles

3 "New" Questions of Peripherality in Europe or How Neoliberal Austerity Contradicts Socio-Spatial Cohesion Costis Hadjimichalis

4 State Power, Spatial Inequality, and Geographical Expertise: Notes on Method Merje Kuus 
Part II Regional and Cohesion Policies (Re-)producing Socio-Spatial Disparities

5 Re-conceptualising Territorial Cohesion Through the Prism of Spatial Justice: Critical Perspectives on Academic and Policy Discourses

Rhys Jones, Sami Moisio, Mikko Weckroth,

Michael Woods, Juho Luukkonen, Frank Meyer

and Judith Miggelbrink

6 Questioning the Convergence of Cohesion and Innovation Policies in Central and Eastern Europe Bradley Loewen and Sebastian Schulz

7 Divergent Paths to Cohesion: The (Unintended) Consequences of a Place-Based Cohesion Policy

Stefan Telle, Martin Špaček and Daniela Crăciun

8 Urban Growth Pole Policy and Regional Development: Old Wine in New Bottles?

József Benedek, Ştefana Varvari and Cristian Marius Litan

9 Reproducing Socio-Spatial Unevenness Through the Institutional Logic of Dual Housing Policies in Hungary Zsuzsanna Pósfai and Csaba Jelinek

Part III Responses to Regional Polarisation and Alternative Perspectives

10 Out-Migration from Peripheries: How Cumulated Individual Strategies Affect Local Development

Capacities

Aura Moldovan 
11 Towards a Progressive Local Development Approach: Insights from Local Community Initiatives in Hungary and Romania

Sorin Cebotari and Melinda Mihály

12 Bypassing Structural Shortcomings: Innovative Firms in Peripheral Regions

Martin Graffenberger

13 Leading Through Image Making? On the Limits of Emphasising Agency in Structurally Disadvantaged Rural Places

Bianka Plüschke-Altof and Martiene Grootens

Part IV Conclusions: About the Relevance of Scientific Research for Political Practice and Policy Making

14 Understanding and Going Beyond the Regional Policy Paradox: Conceptual Contributions to Studying

Socio-Spatial Polarisation in Europe

Garri Raagmaa, Erika Nagy, Franziska Görmar and Thilo Lang

15 Translating Scientific Results: Encouraging Reflective Policies as a Chance for Change

Sorin Cebotari, Tomas Hanell and Thilo Lang 


\section{Notes on Contributors}

József Benedek is Professor of Geography at the Babeș-Bolyai University, Cluj-Napoca, Romania, and Professor of Spatial Economics at the Miskolc University. He is Director of the Research Center for Sustainable Development, Cluj, Romania and Country Ambassador for the Regional Studies Association. His research interest is on regional and urban development in Romania, Hungary and the broader CEE.

Sorin Cebotari is an early career researcher holding a $\mathrm{PhD}$ in Geography from Babeș-Bolyai University. His main areas of interest are socio-technological interplay and its potential to reverse peripheralisation dynamics. In his $\mathrm{PhD}$ work, Sorin looks closely into renewable energy projects and their interplay with local communities in the North-West region of Romania. Throughout his $\mathrm{PhD}$ and his published works, Sorin supports the idea of decentralised energy governance and community-owned renewable energy projects as a resource for sustainable development at the local level.

Daniela Crăciun is a Yehuda Elkana Fellow at the Central European University (Hungary) where she is pursuing a $\mathrm{PhD}$ in the Doctoral School of Political Science, Public Policy and International Relations. 
Recently, she has been a visiting scholar at the University of Yangon (Myanmar), the Center for International Higher Education at Boston College (USA) and the Federal University of Sao Carlos (Brazil). Her research interests lie in the areas of methodology and education policy, specifically higher education internationalisation and international student mobility.

Franziska Görmar is project manager and research fellow at the Leibniz Institute for Regional Geography, Leipzig. She holds a diploma in translation and cultural studies from Leipzig University, Germany. Her research and project activities address urban and regional development, urban regeneration and social innovations.

Martin Graffenberger is a trained economic geographer, early stage researcher at the Leibniz Institute for Regional Geography (IfL) in Leipzig and PhD student at Leipzig University. His research explores innovation activities of firms from peripheral regions, focusing in particular on the relational and spatial contexts and dynamics that drive and shape innovation processes.

Martiene Grootens is a PhD Candidate at the University of Tartu in Estonia. She holds an MSc in International Development Studies from Wageningen University in the Netherlands. Her current research focuses on place leadership and peripheralisation processes and more broadly she is interested in rural sociology and relational thinking.

Costis Hadjimichalis is Professor Emeritus of Economic Geography and Regional Development at the Department of Geography, Harokopio University Athens. He is a radical geographer who is dealing with issues of uneven development, socio-spatial justice and local and regional development. His latest book is Crisis Spaces. Structures, Resistance and Solidarity in Southern Europe, Routledge 2017.

Tomas Hanell is researcher at the University of Helsinki, Department of Geosciences and Geography, the Spatial Policy, Politics and Planning Research Group. He has worked with urban and regional development in the EU, the Baltic Sea Region and the Nordic countries for more than two decades. He has conducted applied quantitative research 
for supranational development organisations (e.g. the European Commission, DG Regio, DG Internal Policies, the OECD, the Nordic Council of Ministers), numerous national ministries throughout Europe, several cross-border cooperation bodies, and a vast number of regional and local level development organisations. Recently he has constructed an instrument for measuring quality of life in EU regions and his current research interests concern the urban-rural dichotomy of well-being and quality of life in Europe.

Ray Hudson is Professor of Geography at the University of Durham, UK. His research addresses economic geographies, processes of combined and uneven development, relations between the economies of the legal and the illegal, and issues of territorial development.

Csaba Jelinek is a junior research fellow at the Centre for Economic and Regional Studies of the Hungarian Academy of Sciences. He holds a $\mathrm{PhD}$ in sociology and social anthropology from the Central European University, Budapest. His research interests include critical urban studies, critical political economy, urban policy making and the anthropology of state.

Rhys Jones is Professor of Human Geography at Aberystwyth University. He has research interests in political geography, cultural geography and historical geography, with a particular focus on the various geographies of the state and its related group identities.

Merje Kuus is Professor of Geography at the University of British Columbia in Vancouver, Canada. She is a political geographer whose work concentrates on geopolitics and policy processes in transnational institutions. Dr. Kuus is the author of Geopolitics and Expertise: Knowledge and Authority in European Diplomacy (Wiley Blackwell, 2014), and Geopolitics Reframed: Security and Identity in Europe's Eastern Enlargement (Palgrave Macmillan, 2007).

Thilo Lang is Head of Department at the Leibniz Institute for Regional Geography, Leipzig, and lecturer at the Global and European Studies Institute of the University of Leipzig. He completed his doctorate in Human Geography at University of Potsdam, Germany and at 
Durham University, UK. His research interests include polarisation processes at multiple levels, innovation outside agglomerations, regional change, transnational comparative urban and regional studies, and shrinking cities and urban regeneration.

Cristian Marius Litan is Associate Professor at Babeș-Bolyai University, Faculty of Economics and Business Administration, Department of Statistics, Forecasting, Mathematics. His research interests are in the field of mathematical and quantitative methods applied in economics and social sciences. He conducted studies involving game theory and applications, applied econometrics and statistics.

Bradley Loewen is a doctoral student at the University of Economics, Prague and visiting student at the University of Tartu. Within the Marie Curie ITN RegPol${ }^{2}$, he was an early stage researcher hosted by MEPCO_-International Advisory Centre for Municipalities in Prague. Trained in urban and regional planning, his research interests include regional policy formulation and strategies for tackling processes of regional growth and decline at multiple scales.

Juho Luukkonen is a post-doctoral researcher in the Department of Geosciences and Geography and at the Institute of Urban and Regional Studies at the University of Helsinki. His current research interests include spatial planning and development policies, Europeanisation, policy transfer, social practices, state spatial transformation and territorial politics.

Frank Meyer is a doctoral researcher at the Leibniz Institute for Regional Geography in Leipzig and the Technical University of Dresden. His current research interests include aspects of Europeanisation and spatialisation with regard to regulating transplantation and organ donation in European countries. Furthermore, he works on discourse theory, social practices, as well as questions of maintaining public services in rural regions suffering from population decline.

Judith Miggelbrink is Professor of Human Geography at the Technische Universität Dresden, Germany. So far, she has worked on 
theories of spatiality, on the European border regime, and on visual geographies. Currently, she is engaged in research projects on health geographies and on discourses about border-related crime.

Melinda Mihály is a junior research fellow of the Hungarian Academy of Sciences, Centre for Economic and Regional Studies. As an early stage researcher of the ITN RegPol${ }^{2}$ and $\mathrm{PhD}$ candidate at the Institute for Geography of the University of Leipzig, Melinda focused on rural social and solidarity economy initiatives and their role in counteracting processes of peripheralisation. Through ethnographic methods, Melinda studied rural social enterprises in eastern Germany and Hungary from the perspective of economic, social and environmental sustainability.

Sami Moisio is Professor of Spatial Planning and Policy in the Department of Geosciences and Geography and at the Institute of Urban and Regional Studies at the University of Helsinki. His research interests include political geographies of Europeanisation, state spatial transformation and urban political geographies.

Aura Moldovan is a $\mathrm{PhD}$ candidate in Human Geography at the Babeș-Bolyai University Cluj-Napoca, and has worked as an early stage researcher within the Marie Curie ITN RegPol${ }^{2}$. She has previously studied urban sociology at the same university in Cluj-Napoca and at the Technical University Darmstadt. Her research interest lies in unequal regional development and territorial mobility, with a regional focus on Romania and Central and Eastern Europe.

Erika Nagy is a senior research fellow at the Centre for Economic and Regional Studies of the Hungarian Academy of Sciences and a senior lecturer at József Attila University, Szeged. Her work focuses on economic geography, comparative studies on transformation of urban hierarchy, urban social geography, global agents and local conflicts in EU cities.

John Pickles is Earl N. Phillips Distinguished Professor of International Studies in the Department of Geography at the University of North Carolina. His research interests lie in the cultural and political economies of Europe, post-socialist transformations in Central Europe, and Euro-Mediterranean border and migration policies. 
Bianka Plüschke-Altof is a lecturer at the University of Tartu, Estonia. She holds a PhD in Social Sciences (Economics) from the University of Tartu in Estonia and an M.A. in Social Sciences (Sociology and Political Science) from Humboldt-Universität zu Berlin in Germany. Her current research focuses on discursive and material peripheralisation processes and more broadly she is interested in rural sociology and discourse analysis.

Zsuzsanna Pósfai was a Marie Curie early stage researcher at the Centre for Economic and Regional Studies of the Hungarian Academy of Sciences in the framework of the Marie Curie ITN RegPol ${ }^{2}$. She received her $\mathrm{PhD}$ from the University of Szeged in the field of economic geography. Her research interests include the financialisation of housing and the uneven development of housing markets, using the approaches of critical geography and critical political economy.

Garri Raagmaa is Associated Professor of Regional Planning at the Department of Geography of the University of Tartu (Estonia). He has published four books and over 70 research papers on regional planning and development focusing on regional innovation and on entrepreneurship, identity and leadership issues. He has taught Regional Planning, Economic Geography and Regional Innovation Systems at several Nordic and Baltic Universities. He has also practised since 1992 as a regional/local development consultant.

Sebastian Schulz is a doctoral student at the University of Tartu/ Estonia. A geographer by training, Sebastian was an early stage researcher in the Marie Curie ITN RegPol ${ }^{2}$ and currently works as a scientific officer in the area of EU cohesion policy and R\&I policy at the DLR Project Management Agency in Bonn. His research explores the rationales of regional and innovation policies in core and peripheral regions, especially in the Central and Eastern European context.

Martin Špaček was an early stage researcher in the Marie Curie ITN $\mathrm{RegPol}^{2}$ on 'Socio-Economic and Political Responses to Regional Polarisation in Central and Eastern Europe' at SPECTRA CE, Slovak University of Technology in Bratislava. He is a $\mathrm{PhD}$ candidate at Comenius University in Bratislava. His work concerns mainly 
international research activities with the focus on regional polarisation in Central and Eastern Europe, social innovations and evaluations of public expenditure programmes.

Stefan Telle was an early stage researcher in the Marie Curie ITN $\mathrm{RegPol}^{2}$ on 'Socio-Economic and Political Responses to Regional Polarisation in Central and Eastern Europe.' He holds a PhD in Spatial Planning and a M.A. in Global Studies. His research focuses on the impact of European integration on state territoriality and politics. Recently, he was a research affiliate at the Central European University (Center for Policy Studies) and a visiting lecturer at the University of Yangon (Department of International Relations).

Ştefana Varvari is lecturer at the Faculty of Economics and Business Administration, Babeș-Bolyai University of Cluj. Her research interests are in regional economics, regional and urban development policies, EU programmes and funds, and sustainable development with a focus on EU and especially on Romania and CEE countries. She holds a PhD in Economics/International Economic Relations.

Mikko Weckroth is a post-doctoral researcher in the Department of Geosciences and Geography and at the Institute of Urban and Regional Studies at the University of Helsinki. His research interests touch upon questions of geographies of well-being and development, urban-rural transformation and the geography of human values.

Michael Woods is a Professor of Human Geography at Aberystwyth University. His research focuses on political geography and rural geography, with particular interests in globalisation, regional development and governance. 


\section{List of Figures}

\section{Chapter 5}

Fig. 1 The cumulative number of hits for the term 'territorial cohesion' on the basis of a Google Scholar search 100

Fig. 2 The cumulative number of hits for the term 'spatial justice' on the basis of a Google Scholar search

\section{Chapter 7}

Fig. 1 Trend analysis of policy concepts in the Lisbon Agenda and the Europe 2020 strategy

Fig. 2 Collocation analysis of the Lisbon Agenda and the Europe 2020 strategy

Fig. 3 Trend analysis of German and Czech cross-border OPs (2007-2013 vs. 2014-2020)

Fig. 4 Trend analysis of [OMS/OMS] OPs across the 2007-2013 and the 2014-2020 period

Fig. 5 Trend analysis of [OMS/NMS] OPs across the 2007-2013 and the 2014-2020 period

Fig. 6 Trend analysis of [NMS/NMS] OPs across the 2007-2013 and the 2014-2020 period

Fig. 7 Correspondence analysis for all German cross-border OPs (2014-2020) 


\section{Chapter 8}

Fig. 1 Evolution in time of average Gini coefficients for all three groups of counties

Fig. 2 (Analysis 1): a Evolution in time of average Gini coefficients for $G R 1$ (treated) and GR2 $\cup G R 3$ (non-treated), respectively. $\mathbf{b}$ Evolution in time of the difference between the average Gini coefficients of the treated versus non-treated groups of counties

Fig. 3 Evolution in time of average Gini coefficients for all three groups of counties

Fig. 4 (Analysis 1): a Evolution in time of average Gini coefficients for $G R 1$ (treated) and GR2 $\cup G R 3$ (non-treated), respectively. $\mathbf{b}$ Evolution in time of the difference between the average Gini coefficients of the treated versus non-treated groups of counties

Fig. 5 (Analysis 2): a Evolution in time of average Gini

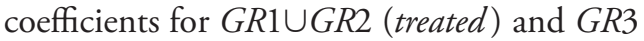
(non-treated), respectively. b Evolution in time of the difference between the average Gini coefficients of the treated versus non-treated groups of counties

Fig. 6 (Analysis 2): a Evolution in time of average Gini

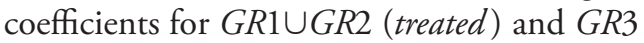
(non-treated), respectively. b Evolution in time of the difference between the average Gini coefficients of the treated versus non-treated groups of counties

Chapter 10

Map 1 Geographic location of the North-West Region and of Sălaj County in Romania

Map 2 Case study area: ten peripheral villages in Sălaj County

\section{Chapter 11}

Map 1 Settlement deprivation map of Hungary, 2011. Kispatak ( $\mathrm{H} 1$, indicated by Mihály) is located in an area where settlements with a high deprivation index are concentrated

\section{Chapter 12}

Fig. 1 Conceptualising firm innovation 
Map 1 Case study area and location of cases in the Erzgebirgskreis 294

Map 2 Case study areas and location of cases in South Estonia 295

Picture 1 MÜHLE premises in Hundshübel 299

Picture 2 Illustration of MÜHLE's product range 299

Picture 3 OSKAR premises in Saarepeedi

Chapter 13

Map 1 Case study areas 


\section{List of Tables}

\section{Chapter 6}

Table 1 Key reports influencing cohesion policy in CEE countries

Table 2 Key trends in competitiveness and convergence in national policy

Table 3 National strategic documents of regional policy in selected CEE countries

Table 4 Interview participants

\section{Chapter 7}

Table 1 Analysed Czech and German cross-border cooperation OPs

\section{Chapter 8}

Table 1 The names and definitions of the analysed time series

\section{Chapter 10}

Table 1 The number of interviews conducted in the case study area 


\section{Chapter 12}

Table 1 Socio-economic characteristics of study regions

Table 2 Characteristics of case firms

\section{Chapter 13}

Table 1 List of interview partners 


\title{
1
}

\section{Re-thinking Regional and Local Policies in Times of Polarisation: An Introduction}

\author{
Franziska Görmar, Thilo Lang, Erika Nagy \\ and Garri Raagmaa
}

This book takes its starting point by considering a threefold polarisation within the EU: an increasing demographic concentration in and around the bigger cities with population decline in many other regions, economic development favouring a smaller number of capital and metropolitan regions with seemingly less economic prosperity in most other regions as well as a spatially and socially uneven distribution of wealth with a growing number of people feeling neglected and favouring rightwing conservative or even extremist political positions in a number of

F. Görmar $(\bowtie) \cdot$ T. Lang

Leibniz Institute for Regional Geography, Leipzig, Germany

T. Lang

Global and European Studies Institute, University of Leipzig, Leipzig, Germany 
recent national elections. At the same time, the future of cohesion policy is again being discussed at the EU level-as happens every couple of years. And there is again the question whether cohesion policy will turn back to its original objectives of supporting the worse off regions in the European Union or whether it will follow the neoliberal course of recent years to foster competitiveness and growth.

Based on these observations, the book asks a couple of questions: What actually is meant when we are speaking about regional and cohesion policies in these times? In which ways is socio-spatial polarisation (re-)produced and how should policy respond to these processes? To what extent should we rethink current spatial policies when aiming for more just ways of development? What are the alternatives to the neoliberal mainstream?

\section{Setting the Scene: Territorial Cohesion as a Core Issue of the European Union}

Since the adoption of the Single European Act in 1985 and at least since the introduction of the Territorial Agenda of the European Union in 2007, socio-spatial cohesion has been identified as one of the core issues of the European Union. However, the goal is far from being achieved. Whereas on a national level, economic development between the different European countries converged (albeit to different degrees), it is apparent that regional inequalities within national states further increased considerably during recent years (Neufeld 2017, 27; Iammarino et al. 2017; for growing income inequalities within states see also OECD 2016). Across Europe, we are witnessing demographic growth and the

E. Nagy

Centre for Economic and Regional Studies, Hungarian Academy of

Sciences (CERS-HAS), Békéscsaba, Hungary

G. Raagmaa

University of Tartu, Tartu, Estonia 
increasing economic prosperity of a small number of big agglomerations, mainly capital cities and their surroundings. This seems to be at the expense of a growing number of rural and old industrial regions. These regions are characterised by economic and demographic stagnation or even decline (see Eurostat 2017) and the outmigration of mainly young people to the better off, mainly metropolitan areas which also attract the largest share of transnational migrants (Lang and Haunstein 2017; Dax and Fischer 2017). In a growing number of declining regions, those people who stay have an increasing feeling of being left behind (Neu 2006). Thus, the big metropolitan areas and urban agglomerations can be seen as the winners of regional polarisation, whereas rural and old industrial regions face increasing development problems. However, this is only one part of the finely grained picture which is characterised by multiple divides across Europe. Diverging economic and social developments can be witnessed on various scales "between states and regions; within regions, between core areas and peripheral areas; and between prosperous metropolitan regions and less prosperous ones" (Iammarino et al. 2017, 4) and, we would add following Kuus and Hadjimichalis in this volume, also between states or groups of states.

Since the 2004/2007 enlargement of the European Union, it has never been as apparent as it is now that cohesion policy continuously fails to achieve its ultimate goal, a balanced development of all regions in Europe which, at the end, would lead to more spatial justice. The growing focus on competitiveness and growth-deeply rooted in prevailing neoliberal logics of development-along with constraining policies of austerity even contradicts the efforts undertaken to balance uneven development in Europe (Faragó and Varró 2016; Agnello et al. 2016). Given their high importance for the economic, social and political future of the European Union (Iammarino et al. 2017), cohesion policies, the underlying power structures and their impacts have to be questioned, and new responses to regional polarisation have to be developed. Whereas there are numerous studies at different spatial levels evaluating and analysing the impact of EU regional and cohesion policies and stressing their limited success (e.g. Hadjimichalis and Hudson 2014; Piattoni and Polverari 2016; Begg 2010), this book suggests a perspective that goes beyond the analysis of current forms of policy 
and governance. It works out the political geographies of spatial injustice and seeks alternative approaches to regional and local development offering new avenues towards socio-spatial cohesion instead of furthering polarisation through focusing on global competitiveness.

Based on recent research about socio-spatial polarisation and peripheralisation processes in Europe, the book combines conceptual contributions and empirical research, both aiming to better understand these processes and linking it to current debates on territorial cohesion. We argue in favour of a political geography approach which adds to these debates the notion of "spatial justice" (e.g. Soja 2009; Harvey 1973). The growing focus on neoliberal concepts in EU and national policies such as competitiveness, innovation and growth shows us that it is very timely to discuss our understandings of "territorial cohesion" in its multiple dimensions. The normative concept of (spatial) justice allows us to question these prevailing foci, analyse the impacts of such policies and discuss arising alternatives. In this context, the book shall also contribute to the debate what kind of regional and local development approaches are fruitful to reduce current disparities and achieve progress towards a more balanced territorial development (see Pike et al. 2017b).

In the following section of this introduction, we expand, on the one hand, more on our understandings on socio-spatial polarisation and, on the other hand, spatial justice as a useful concept to overcome a narrow economic understanding of development. The third, fourth and fifth sections will introduce the three main parts of the book and their respective contributions. The third section is dedicated to the contributions of this book dealing with questions of power, since unequal power relations, especially on the European level, do play a considerable role when we are speaking about socio-spatial polarisation. In the fourth section, we shed light on the reasons why cohesion policy fails in creating a more balanced territorial development and instead reproduces socio-spatial disparities. In contrast, the fifth section of the introduction will show that, in spite of increasing regional disparities, there is some room for alternative perspectives and responses to polarisation that show potential to influence decision and policy making in the long run. Finally, we conclude with a call to rethink regional policies and find more just answers to current problems of regional development. 


\section{Spatial Justice as a Means to Overcome Polarisation}

In recent years, an understanding of polarisation as a relational, multidimensional and multi-scalar concept has emerged (see also PoSCoPP 2015; Nagy et al. 2015; Lang 2015; Kühn 2015, 2016) which includes at the same time processes of peripheralisation as well as centralisation. These processes comprise not only economic, but also infrastructural, political as well as social and discursive aspects (Kühn and Lang 2017; Kühn and Weck 2013). Leading to very different problems in fast growing, mainly metropolitan regions and shrinking and/or economically declining regions, centralisation as well as peripheralisation cause specific patterns of polarisation and affect the ultimate goal to achieve territorial cohesion or, in other words, spatial justice.

This development is closely linked to a shift in European cohesion policies during recent decades. During the 1980s and the early 1990 s, the goal was to ensure balanced growth between the regions by compensating those areas which did not profit from the integrated European economy. From the late 1990s onwards, and particularly after the 2005 relaunch of the Lisbon Agenda and the Europe 2020 strategy, the focus of the Structural Funds and Cohesion Policy changed to the promotion of faster growth and more employment, enhancing the overall competitiveness of the whole European Union (Faragó and Varró 2016, 7; see also Avdikos and Chardas 2016). This holds even truer after the 2007/2008 crisis. In its aftermath, territorial solidarity between European regions decreased further and even more attention was directed to cities and city-regions as economically and politically strong centres at the expense of the so-called "peripheries" (Faragó and Varró 2016, 8).

Although the EU as a whole seems to be back on a growth path (judged from a mainstream perspective), the newly generated wealth does not reach the people in a sufficient and territorially balanced way. In recent decades, economic growth has de-coupled from the growth of well-being and life satisfaction. This is in particular visible in Central and Eastern Europe where the focus on a competitive and innovative economy has led to further centralisation and peripheralisation and, as a result, 
to "consequential geographies of (in)justice" (Soja 2010, 1) or, in short, spatial (in)justice. The people living in places affected by this spatial injustice seem to have the increasing feeling that their places of living "don't matter" to decision-makers and urban elites (Rodríguez-Pose 2018).

In contrast to this evidence, Edward Soja (2010) defines "spatial justice" as the equitable distribution of resources, services, and access. In this sense, it can be seen as a basic human right and thus a powerful concept to overcome polarisation. It is not restricted to the economic realm but links social justice with space and can bring notions of well-being, quality of life, as well as ecological aspects in the debate on territorial cohesion (see Jones et al. in this volume).

In this sense, "spatial (in)justice" is not only the outcome of social, political, economic, ecological and cultural processes (e.g. outmigration, diminishing public services, etc.), but also a "dynamic driving force affecting these processes in significant ways" (Soja 2010, 2; for the dialectic relation between the different dimensions, see also Pike et al. $2007,1258)$. This means that the socio-communicative peripheralisation of certain regions in turn affects these processes. It could lead to a vicious cycle of decline and stigmatisation and hinder regeneration of the affected regions. Nevertheless, recent studies show that polarisation and peripheralisation have to be understood as dynamic processes that can be influenced and reversed (Lang 2015; Kühn and Lang 2017). Residents of peripheralised regions, for example, can even use negative images to get access to specific funds and support structures and open up new paths of development (Plüschke-Altof 2017). More spatial justice would be achieved if the people affected by peripheralisation processes gained greater control over the development of their region(s) and were capable of building "multiscalar institutional and informal networks of solidarity” (Hadjimichalis 2011).

Thus, the question of what kind of regional and local development is needed (Pike, Rodríguez-Pose and Tomaney 2007) is of utmost importance to finally achieve "spatial justice" or, in EU terms, territorial cohesion. Today, it seems widely acknowledged that development not only comprises an economic dimension but includes also social, ecological, political and cultural concerns leading to more complexity in decision-making. This complexity asks for a continuous debate about 
fundamental values like democracy, equity, justice, fairness, liberty and solidarity (see Hadjimichalis 2011; Soja 2010; Pike et al. 2007). It is a highly political question what regional and local development should look like as it concerns "competing visions of the 'good society" (Pike et al. 2007, 1262) which are constantly changing over time. Which of these visions prevails in the debates on regional development depends upon the institutional structures and power relations and the underlying interests of the involved actors as we will show in the chapters of the first part of the book.

\section{Socio-Spatial Polarisation in the European Union and Questions of Power}

The recent crisis and the following economic recession raised new polarities and reproduced historical fault lines within Europe, making the failure of policies that targeted stronger cohesion apparent and placing the relevance of institutional structures, practices and underlying principles at the centre of public discourses. Nevertheless, as is discussed in academic and also in policy papers, recent shifts in economic power and political conflicts are rooted in two developments which had already evolved prior to the crisis: (1) in the long-term geopolitical and geo-economic changes that questioned the dominance of the global North in controlling global flows and placed the European economy on a slow-growth track (UNCTAD 2010, 2017; Hudson 2016) and (2) in the pre-crisis inequalities within Europe that manifested in uneven patterns of capital flows, innovation and knowledge production, labour productivity and migration (Hadjimichalis 2011; Ehrlich et al. 2012). The changing position of the European economy in global flows, persisting inequalities and the recent emergence of new dimensions of unevenness (indebtedness, the spread of deep poverty, and the decay of public services resulting from austerity schemes, etc.). Moreover, the regulative deficits revealed by the crisis raised criticism towards existing institutional structures and reheated debates on institutions as agents of change also in academic circles (Pike et al. 2017a; Hadjimichalis and Hudson 2014). 
The unfolding discourse on institutions as mediators of power driving uneven development is linked to debates on retheorising power itself. The latter results in a shift from understanding power as a force and authority exercised by individuals or institutions to advance their (or particular groups') interests towards a process- and practice-focused approach and considering power as a relational effect that is at work in all social interactions. Accordingly, the multi-dimensionality of power and the variety of fields of power in which individuals are acting simultaneously gained more attention, and various modalities of power were identified from coercion, domination, authority to manipulation and seduction (Hudson 2007; Allen 2003). Relying on this broad understanding of power, scholars of various academic fields researched institutions as arenas of social struggles embedded in a multiplicity of actual social relations, being changed from inside and outside, yet preserving and reproducing historical values, norms and practices. Studies with such foci highlighted how institutional structures and practices (regulatory regimes, power geometries, policies) are shaped by and reproduce power relations and how they operate and shape everyday social practices and consequently regional and local development in a multiple and uneven way (Brenner 2009; Hudson 2007; Massey 1993).

Research on institutional practices, their socio-cultural contexts and underlying power relations advanced and deepened our knowledge on the mechanisms of polarisation processes, the emergence of new dimensions of inequalities and the differentiation at a European scale and also within European 'cores' and 'peripheries' at national and sub-national scales (Peck et al. 2012; Fischer-Tahir and Naumann 2013; Ehrlich et al. 2012; Kuus in this volume). Even though multiple institutional rearrangements (of markets, firms, NGOs, state and semi-state organisations, etc.) were identified as drivers of growing socio-spatial inequalities that all had their spatial implications, it was the reorganisation of state power that was placed at the very heart of debates, due to the centrality of state agency (as a context and as a cause) in the unfolding globalisation and the neoliberalisation processes underpinning it (Brenner 1999; Jessop 1993). The latter embraced the privatisation of public assets along with shrinking state roles in operating the systems of collective consumption, liberalisation of flows, re-regulating 
the labour-capital nexus by weakening the former's position, and the involvement of non-state organisations in governing social relations (Harvey 2007; Bockmann 2012). By driving such changes, the state emerged as an agent of uneven distribution of power and wealth through the changing regulative framework and the related institutional practices (backing financialisation, introducing austerity schemes, subordinating social policies to economic growth, shifting responsibilities to regional and local actors, etc.) and the production of narratives and new normalities for the social reality of the unfolding regime such as competitiveness, flexibility, and self-interest/reliance (Jessop and Osterlynck 2008; Hudson 2007).

The changing role of state institutions has been widely discussed in relation to their spatial reorganisation. Rescaling processes of national state power were a central issue even though scalar reorganisation was going along with other spatial transformations such as the rise of horizontal networks, new modalities of place making and changing territorialities (Brenner 1999). The debates were revolving around the state as the key agent of producing a new spatial (scalar) fix in the neoliberal regime of capitalism (Jessop 2010), the significance of architectures of institutional models driving state reorganisation (Bohle and Greskovits 2007), and the technologies of power in particular socio-spatial contexts. Yet, the growing body of scholarly work on the European context (i.e. on the emerging networked governance, changing border regimes, the growing importance of horizontal organisations in institutional learning and policy translations, rescaling processes as highly complex power games within European institutional settings—see also Kuus in this volume) and, moreover, the lessons of the recent crisis led to more complex understandings of the agency of various state institutions in uneven development (Jessop 2010; Kuus 2011; Hadjimichalis and Hudson 2014). The rise and the post-crisis revival of neoliberalism have been widely discussed as series of re-regulative processes reinforcing market rule over social relations, placing not only historical national institutions as agents in focus, but their international embedding resulting in conflicts, learning, policy experimentation and structural changes across scales. Relying on this (relational) approach, the institutional landscape driving socio-spatial polarisation has been researched and 
discussed as a highly variegated, rapidly changing set of structures and practices that embody shifting power relations from elected bodies to experts, from national institutions to international bodies and financial organisations that mediate particular national/group interests (Brenner 2009; Peck et al. 2012).

Understanding the power relations and strategies driving institutional restructuring, as well as the socio-cultural diversity and interrelatedness of institutional practices, we can reveal (and also challenge) their bias towards reproducing inequalities, and gain deeper insight into the mechanisms behind reproducing unevenness and the failures of cohesion policies in making a more just European society. By doing that, we can also enhance existing knowledge on the recent crisis and the resurgence of neoliberalism through the lens of complex, interrelated and contested European institutional settings, such as the limits of national state agency (austerity schemes imposed on national governments, public policies geared towards supporting capital accumulation instead of socio-spatial solidarity, the re-regulation of labour-capital relations, etc.) and emerging conflicts in the arenas of international organisations (Jessop 2010; Hadjimichalis and Hudson 2014).

Along these lines, the first part of this book engages with current power structures in Europe and the resulting polarisation processes. Ray Hudson and John Pickles engage in a conversation based on their seminal works on critical economic geography and regional development. They emphasise that (economic) uneven development is inherent to capitalist economies and goes hand in hand with political asymmetries and democratic deficits which manifest themselves in urban and regional policy networks favouring "the main centres of growth and affluence" and marginalising the region(s). Ray Hudson frames the European Union as "a project of and for the political and capitalist economic elites in Europe" (Hudson 2017, 139) where uneven and combined development is reproduced, "especially between the national economies and states of 'north' and 'south' and 'east'. Given this uneven nature of capitalism, they do see the risk to "rais[e] hopes that cannot be delivered", although there are some forms of capitalism that seem to be more progressive and should be encouraged and supported. Hence, they see a clear need for a political economic geography. 
In a similar vein, Costis Hadjimichalis argues that the so-called "cohesion policies" are contradictory to the priorities established in the Lisbon strategy which are "regional competitiveness", "knowledge economy" and "growth and jobs". These strategies are defined more or less solely by the economically "successful" states such as France, UK, the Benelux states, Scandinavia and particularly by Germany that aims at imposing its "ordoliberalism" on the whole European Union. The path dependency of the regions and questions of redistribution seem to be widely ignored. Instead, only a few successful star-regions are promoted as "best practices" favouring at the end only large cities at the expense of smaller ones and agricultural regions. The recent crisis has shown that these strategies do not lead to territorial cohesion but to increased spatial injustice. Furthermore, three other factors, "financialisation", "the rise of a new rentier economy", and "private and public debt", have been introduced. These factors strengthen the existing power imbalances and further the importance of metropolitan regions and the continuous marginalisation of rural peripheries.

The contribution of Hadjimichalis already indicates what Merje Kuus reveals in her chapter on state power, spatial inequality and their interrelationship with the flows and networks of (geographical) expertise. Spatial planning in Europe is becoming an increasingly transnational process that combines national, sub-national and international elements in new and ever-changing combinations. Thus, the centres and margins of policy expertise are fluid and depend not only on formal training and negotiation skills, but also on personal networks and a certain feeling for Brussels' parquet. Diplomats from the richer member states do seem to have a better stand as they tend to dispose of these networks as a result their pre-Brussels training and can build on long-standing traditions of policy expertise. Nevertheless, European and national interests cannot be isolated from each other, but are intertwined and often diffuse. Therefore, Kuus points to the difficulties in grasping these specific and at the same time diffuse patterns in scientific analysis and argues for overcoming the "methodological nationalism of our analytical toolbox" and applying a transnational lens while doing research on "the ever-shifting patterns of economic, political and symbolic peripherality". 


\section{$4 \quad$ Regional and Cohesion Policies (Re-)Producing Socio-Spatial Disparities}

The chapters in the second part of the book discuss European and regional policies and their impact on territorial cohesion within and between EU member states. Looking at the Europe 2020 strategy and its three priorities of "smart, sustainable and inclusive growth" (EC 2010), there is apparently a contradiction between the goals to enhance social and territorial cohesion on the one hand and to achieve competitiveness of each single region and Europe as a whole on the other hand. While regional policies claim to contribute to a decrease in regional disparities and to foster convergence between the regions, their application often actually intensifies regional polarisation, especially in Southern, Central and Eastern Europe (Hadjimichalis in this volume).

This spatial polarisation is not a linear process but a consequence of a combination of various factors. Governance is one of them. For instance, Central and Eastern European countries (CEEC) carried out numerous administrative and public policy reforms during the last 25 years (Swianiewicz 2010). There are several factors that made CEE governance evolve considerably differently from governance in the older member states of the European Union. Decision-making was concentrated into larger, arguably globally more competitive units. Consequently, the centralisation of power from lower administrative tiers to the national central agencies led to a (political) peripheralisation of remote regions. At the same time as Western Europe continued on a devolution track, CEEC made a sharp turn and did gradually centralise their public administration (Loewen and Raagmaa 2018; Loewen 2018). Although many academics and policy makers saw multilevel governance and several other EU policy catchwords as promising approaches to development, they do not seem to work everywhere in a similar manner (Špaček 2018). Europeanisation has never been a uniform and parallel process in all countries and European policy concepts have obtained different meanings in different countries due to distinct administrative structures, normative development models and politically 
accepted regional policy paradigms (Loewen and Raagmaa 2018). History and an administrative culture rooted in the past do matter: path-dependency is one of the factors shaping the real application of policy.

Many authors have underlined that there are no one-size-fits-all solutions (Rodríguez-Pose 2018; Iammarino et al. 2017). However, EU directives often ignore the specifics of European peripheral regions and countries. Furthermore, there are many more hidden contestations. In order to secure the usage of EU structural funds, for instance, double standards have been created: official project reports normally show good results and are in turn summarised in regional and country reports as a great success (Raagmaa and Stead 2014). For the purpose of fighting against fraud, the European Commission has strengthened accountability (at the same time preaching about simplification) resulting in even more centralisation. The related complex bureaucratic rules nurture a city-based project class and specialised firms and exclude peripheral localities that are unable to co-finance and manage such projects. That way, the gap between real needs and what policies can achieve for concrete places, thus spatial injustice, is rising.

The authors in the second part of this book criticise the strong growth-oriented focus of European cohesion and regional policies. Rhys Jones et al. argue that more attention should be paid to the academic literatures on spatial justice, human capabilities and agency that might help to spatialise the European Union's social model in more effective ways. The authors claim that applying more plural and long-term conceptions of 'development', 'well-being' and 'justice' could help to formulate regional policies that contribute more directly to the well-being and welfare of people in various parts of Europe.

The focus on economic development in cohesion policies is also apparent for Bradley Loewen and Sebastian Schulz. They have observed that despite the theoretical incompatibility between cohesion and innovation policies, the two areas often converge in a common economic strategy and further rather than diminish regional disparities. "Nevertheless, the traditional aims of Cohesion Policy to support backward regions are still seen to be important for stabilising 
socio-economic processes related to regional growth and decline, as national policy experts have been shown to recognise incompatibilities between cohesion aims and growth-through-innovation strategies". Given this fact, the authors argue that economic growth and innovation objectives should be disconnected from Cohesion Policy and refocus on its traditional domains, such as infrastructure or social investment in underdeveloped regions.

The same shift from employment and social objectives to growth and innovation is revealed by the analysis of Stefan Telle, Martin Špaček and Daniela Craciun. However, looking closer at cross-border cooperation programmes between Germany, Austria, the Czech Republic and Slovakia in the funding periods 2007-2013 and 2014-2020, they have found a significant difference in the strategic focus in old (Germany and Austria) and new (Czech Republic and Slovakia) member states with a stronger emphasis on growth and innovation in old and on employment and cohesion in new member states.

Along with the focus on growth and innovation, spatial development policies often centre on urban growth poles assuming that their successful development will create spillover effects that drive the development and economic growth of more remote regions. József Benedek, Ștefana Varvari and Cristian Marius Litan contradict this assumption in their chapter by highlighting that regional disparities in Romania (and in other countries) still increased in the current funding period despite the new growth pole strategies. These growth pole strategies are good examples for a Europeanisation process that is uncritically pushed further without taking into account national and regional characteristics.

The reproduction of socio-spatial unevenness through a very specific policy area (housing) is observed by Zsuzsanna Pósfai and Csaba Jelinek. They reveal the strongly dualistic pattern of Hungarian housing policies and trace how capital investment in housing is channelled and mediated by public policies. The authors claim that state intervention in Hungary has deepened inequalities in the housing market on various scales_-from the European to the neighbourhood scale-by promoting a middle-class oriented, depth-based property model while having very little support for social housing models. 


\section{Responses to Regional Polarisation and Alternative Perspectives}

The third part of the book will focus on strategies to cope with regional polarisation on a micro level to address the responses of individuals, firms and communities while acknowledging their limitations. The chapters in this part are based on the conviction that a dignified life, creativity and satisfaction (Iammarino et al. 2017, 3) are as important as social innovations, new economic approaches and diversification of the economic basis of the region. Scholars have increasingly argued in recent years for place-sensitive and distributed policies (Iammarino et al. 2017; Jones et al. in this volume; Küpper et al. 2017) that address all dimensions of regional development alike and do not focus solely on the economic realm. We think that every region or locality has its own specific needs and concerns, which have to be addressed (Dax and Fischer 2017; Jones et al. in this volume).

The first chapters in this book show that regional and innovation policies often further regional polarisation instead of achieving cohesion. Neoliberalism is about to hollow out the foundations of a social market economy. Within most operational programmes, the overemphasised competitiveness objective overruns distributive elements and often hinders innovative bottom-up movements. Nevertheless, such local initiatives do exist across Europe: for example, there are many quite successful social economy initiatives working in small niches towards a more just form of economic development that focuses on the well-being of individual people (Küpper et al. 2017). There are teams of local decision-makers managing to re-invent formerly stagnant places and regions by introducing new forms of local and regional governance and turning around negative images of places (Plüschke-Altof 2017; Plüschke-Altof and Grootens in this volume). There are also business cases of innovative companies operating far from the so-called hotspots of the global economy, yet still managing to be successful in global markets (Graffenberger in this volume). Thus, regional development strategies have to take into account the specific social and economic needs of regions and of regional and local actors. In many 
cases, traditional approaches to regeneration (e.g. attempting to restore growth by attracting enterprises, investment, and a skilled population) are not the best option for such regions. There are alternatives that maintain good quality of life for the populations of "peripheral" regions and a good economic environment for existing enterprises (Küpper et al. 2017, 230). One key element here could be to build communication platforms and support networking activities (see Graffenberger in this volume).

However, regional development is not only a question of empowering regional and local actors. Governments have to set the necessary frameworks to support structurally weak regions and locations (e.g. regulations for public service provision, municipal income, etc.). The responsibility for that must not be shifted to local and regional actors but is in the very competence of the state (Plüschke-Altof and Grootens in this volume; Plüschke-Altof 2017; see also the debate about regional engagement of businesses and civil society organisations in Knieling et al. 2012). It is a question of how exogenous (state-influenced) and endogenous (bottom-up) approaches can be coordinated among the different levels to bring about harmonious collaboration in all dimensions and to reduce inequalities (Jones et al. in this volume; Hudson and Pickles in this volume).

The contributions in the third part of the book seek to better understand the currently dominant social, political, economic and discursive tendencies towards polarisation and ask what we can learn from such cases and initiatives and how we can help to achieve more equal societies and more balanced spatial development.

Aura Moldovan outlines out-migration as an individual life strategy, which ultimately affects local development capacities. Using the example of North-West Romania, she shows that commuting or migration flows are, on the one hand, contributing to uneven development while being at the same time an outcome of regional inequalities. In focusing on individual life stories of people coping with the increasing disparities of the region they live in, she uncovers the issues that they are facing like missing higher education and high-income employment opportunities. Furthermore, she reveals the dependency of the researched regions on external funding to implement modern infrastructures and develop local potential.

Dependence on external funds is also visible in the case of the Hungarian and Romanian community-based initiatives that Sorin 
Cebotari and Melinda Mihály are investigating. Renewable energy projects and social and solidarity economy initiatives that use these external funds do have important strategic potential for communitycentred sustainable local development. However, the room for manoeuvre of community-based initiatives is constrained by a centralised logic of organisation, limited space for public participation and existing policy practices and administrative norms. Consequently, community-based initiatives in Hungary and Romania still fail to fully exploit the existing potential for community-centred, more sustainable local development.

Nevertheless, the example shows that social innovations do emerge in peripheral places. The same is true for business innovations. However, firms in peripheral regions are often confronted with complex situations, which limit their efforts in organising innovation activities. Martin Graffenberger presents examples from South Estonia and the Erzgebirgskreis in Germany that show how firms can overcome the limitations of their regional environments by adopting a dual strategy of strategically mobilising ties to external actors and maintaining/expanding internal capacities.

In the last chapter of the third part of the book, Bianka PlüschkeAltof and Martiene Grootens point to the limits of a purely actor-centred approach to regional development. Using the concepts of leadership and place-making as analytical lenses, they acknowledge the potential of both approaches in dealing with regional polarisation. However, they see the need to critically reflect on newly emerging problems in structurally disadvantaged rural areas, such as the idealisation and responsibilisation of local leadership. Local response strategies do have certain limits and practitioners and researchers have to reflect upon the complexity of regional and local development and regional polarisation.

\section{Time to Re-think Spatial Policies}

Currently, regional policies are widely discussed at the EU level with regard to a most likely more restricted budget due to the exit of the United Kingdom. The 7th Cohesion Report (EC 2017) shows that 
cohesion policies do have a considerable impact on so-called "lagging" regions in Eastern and Southern Europe where GDP growth is the highest in Europe. However, this impact is foremost an economic one. At the same time, the EU Social Progress and the European Quality of Government Indices have the lowest scores in these regions (EC 2017). Thus, economic growth does not seem to go hand in hand with political and social satisfaction, public participation or individual wellbeing. This fact underlines our plea to re-think spatial policies considering alternative approaches going beyond purely economic growth.

This book describes the current power structures and prevailing policy paradigms and argues for a critical re-consideration of the effects of the last two programming periods of European funding. It seems to us that global, European and national policies are slowly, but increasingly aware of the challenges we are facing. For instance, the United Nations address with their Sustainable Development Goals (UN 2015), besides inclusive and sustainable economic growth and many others, explicitly the reduction of inequalities and poverty as well as the promotion of well-being (in a similar vein, see OECD 2016). In Europe, policy makers do acknowledge existing inequalities although mostly in the economic realm and with different propositions for their solution. For instance, the migration of well-qualified people from Eastern to Western European countries and from rural to urban areas and its negative consequences on regional and local development (such as the loss of social capacities) is widely recognised (EC 2017).

Up to now, politics and regional development policies tend to focus on so-called best practice examples neglecting the wider context in which these are embedded (see Hadjimichalis in this volume). It is often assumed that these examples can be transferred to any other region in a top-down manner without taking into account the specific institutional arrangements, decision-making structures and local actors in the regions. Actors in the economic and political centres define the (European) priorities for development and choose the corresponding best practices from their perspective. In contrast, we are calling on people in every region and locality and on society as a whole to think about which priorities based on which values should be set (Pike et al. 2007, 1255). 
Spatially just policies should give, on the one hand, greater control to those people who are affected by polarisation processes, giving them the voice, the power and the capabilities to define their own priorities and develop place-based approaches to overcome peripheralisation (see Jones et al. in this volume). On the other hand, there are structural challenges in many peripheralised and marginalised places that cannot be neglected by the centres. Governmental decision-makers have to be aware of multiple peripheralisation, take over the responsibility and adjust existing policy frameworks towards a cooperative and participatory democracy (Piattoni and Polverari 2016) based on the values of solidarity and cohesion (see Plüschke-Altof and Grootens in this volume). Policies have to focus on people enhancing their opportunities where they live (Rodríguez-Pose 2018) and providing them with a solid and stable policy framework and appropriate social and physical infrastructures. This book aims to be a resource for all scholars in academia and practice working towards these issues.

\section{References}

Agnello, Luca, Giorgio Fazio, and Ricardo M. Sousa. 2016. "National Fiscal Consolidations and Regional Inequality in Europe." Cambridge Journal of Regions, Economy and Society 9: 59-80. https://doi.org/10.1093/cjres/ rsv033.

Allen, John. 2003. Lost Geographies of Power. Oxford: Blackwell.

Avdikos, Vasilis, and Anastassios Chardas. 2016. "European Union Cohesion Policy Post 2014: More (Place-Based and Conditional) Growth-Less Redistribution and Cohesion." Territory, Politics, Governance 4 (1): 97-117. https://doi.org/10.1080/21622671.2014.992460.

Begg, Iain. 2010. "Cohesion or Confusion: A Policy Searching for Objectives." Journal of European Integration 32 (1): 77-96. https://doi. org/10.1080/07036330903375115.

Bockmann, Johanna. 2012. "The Political Projects of Neoliberalism." Social Anthropology 20 (3): 310-17. https://doi.org/10.1111/j.1469-8676.2012. 00208.x. 
Bohle, Dorothee, and Béla Greskovits. 2007. "The State, Internationalization, and Capitalist Diversity in Eastern Europe." Competition and Change 11 (2): 89-115. https://doi.org/10.1179/102452907X181929.

Brenner, Neil. 1999. "Globalisation as Reterritorialisation: The Re-scaling of Urban Governance in the European Union." Urban Studies 36 (3): 431-51. https://doi.org/10.1080/0042098993466.

Brenner, Neil. 2009. "Open Questions on State Rescaling." Cambridge Journal of Regions, Economy and Society 2 (1): 123-39. https://doi.org/10.1093/ cjres/rsp002

Dax, Thomas, and Michael Fischer. 2017. "An Alternative Policy Approach to Rural Development in Regions Facing Population Decline." European Planning Studies 26 (2): 297-315. https://doi.org/10.1080/09654313.201 7.1361596.

EC-European Commission. 2010. "Europe 2020. A European Strategy for Smart, Sustainable and Inclusive Growth.” Brussels. http://ec.europa.eu/ eu2020/pdf/COMPLET\%20EN\%20BARROSO\%20\%20\%20007\%20 -\%20Europe\%202020\%20-\%20EN\%20version.pdf.

EC-European Commission. 2017. "My Region, My Europe, Our Future." Seventh Report on Economic, Social and Territorial Cohesion. Luxembourg: Publications Office of the European Union. http://ec.europa. eu/regional_policy/sources/docoffic/official/reports/cohesion7/7cr.pdf.

Ehrlich, Kornelia, Agnes Kriszan, and Thilo Lang. 2012. "Urban Development in Central and Eastern Europe-Between Peripheralization and Centralization?" DisP_The Planning Review 48 (2): 77-92. https://doi.org/ 10.1080/02513625.2012.721611.

Eurostat. 2017. "Eurostat Regional Yearbook." Subchapter on Population Statistics at Regional Level. http://ec.europa.eu/eurostat/statistics-explained/ index.php/Population_statistics_at_regional_level\#Population_change. Accessed 21 February 2018.

Faragó, László, and Krisztina Varró. 2016. "Shifts in EU Cohesion Policy and Processes of Peripheralization: A View from Central Eastern Europe." European Spatial Research and Policy 23 (1): 5-19. https://doi.org/10.1515/ esrp-2016-0001.

Fischer-Tahir, Andrea, and Matthias Naumann, eds. 2013. Peripheralization: The Making of Spatial Dependencies and Social Injustice. Wiesbaden: Springer.

Hadjimichalis, Costis. 2011. "Uneven Geographical Development and SocioSpatial Justice and Solidarity: European Regions After the 2009 Financial 
Crisis." European Urban and Regional Studies 18 (3): 254-74. https://doi. org/10.1177/0969776411404873.

Hadjimichalis, Costis, and Ray Hudson. 2014. "Contemporary Crisis Across Europe and the Crisis of Regional Development Theories." Regional Studies 48 (1): 208-18. https://doi.org/10.1080/00343404.2013.834044.

Harvey, David. 1973. Social Justice and the City. Oxford: Blackwell.

Harvey, David. 2007. "Neoliberalism as Creative Destruction." The Annals of the American Academy of Political and Social Science 610 (1): 22-44. https:// doi.org/10.1177/0002716206296780.

Hudson, Ray. 2007. "Regions and Regional Uneven Development Forever? Some Reflective Comments Upon Theory and Practice." Regional Studies 41 (9): 1149-60. https://doi.org/10.1080/00343400701291617.

Hudson, Ray. 2016. "Rising Powers and the Drivers of Uneven Global Development." Area Development and Policy 1 (3): 279-94. https://doi.org /10.1080/23792949.2016.1227271.

Hudson, Ray. 2017. "Facing Forwards, Looking Backwards: Coming to Terms with Continuing Uneven Development in Europe." European Urban and Regional Studies 24 (2): 138-41. https://doi.org/10.1177/ 0969776416689230.

Iammarino, Simona, Andrés Rodríguez-Pose, and Michael Storper. 2017. "Why Regional Development Matters for Europe's Economic Future." Working Paper 07/2017, Publications Office of the European Union, Luxembourg. http://ec.europe.eu/regional_policy/sources/docgener/work/ 201707_regional_development_matters.pdf.

Jessop, Bob. 1993. "Towards a Schumpeterian Workfare State? Preliminary Remarks on Post-Fordist Political Economy." Studies in Political Economy 40 (1): 7-39. https://doi.org/10.1080/19187033.1993.11675409.

Jessop, Bob. 2010. "The 'Return' of the National State in the Current Crisis of the World Market.” Capital \& Class 34 (1): 38-43. https://doi. org/10.1177/0309816809353480.

Jessop, Bob, and Stijn Oosterlynck. 2008. "Cultural Political Economy: On Making the Cultural Turn Without Falling Into Soft Economic Sociology." Geoforum 39 (3): 1155-69. https://doi.org/10.1016/j.geoforum.2006.12.008. Knieling, Jörg, Frank Othengrafen, and Tobias Preising. 2012. "Privatisierung von Stadt- und Regionalentwicklung: Gesellschaftlicher Nutzen oder Verwirklichung von Unternehmenszielen? Corporate Spatial Responsibility 'Oder, Corporate Spatial Strategy'?' Raumforschung und Raumordnung 70 (5): 451-64. https://doi.org/10.1007/s13147-012-0188-5. 
Kühn, Manfred. 2015. "Peripheralization: Theoretical Concepts Explaining Socio-Spatial Inequalities." European Planning Studies 23 (2): 367-78. https://doi.org/10.1080/09654313.2013.862518.

Kühn, Manfred. 2016. Peripherisierung und Stadt: Städtische Planungspolitiken gegen den Abstieg. Urban Studies. Bielefeld: Transcript.

Kühn, Manfred, and Sabine Weck. 2013. "Peripherisierung-Ein Erklärungsansatz zur Entstehung von Peripherien.” In Peripherisierung, Stigmatisierung, Abhängigkeit? Deutsche Mittelstädte und ihr Umgang mit Peripherisierungsprozessen, edited by Matthias Bernt and Heike Liebmann, 24-46. Wiesbaden: Springer VS.

Kühn, Manfred, and Thilo Lang. 2017. "Metropolisierung und Peripherisierung in Europa-Eine Einführung." Europa Regional 4/2015 (2017): 2-14. http://nbn-resolving.de/urn:nbn:de:0168-ssoar-53587-3.

Küpper, Patrick, Stefan Kundolf, Tobias Mettenberger, and Gesine Tuitjer. 2017. "Rural Regeneration Strategies for Declining Regions: Trade-Off Between Novelty and Practicability." European Planning Studies 26 (2): 229-55. https://doi.org/10.1080/09654313.2017.1361583.

Kuus, Merje. 2011. "Whose Regional Expertise? Political Geographies of Knowledge in the European Union." European Urban and Regional Studies 18 (3): 275-88. https://doi.org/10.1177/0969776411406034.

Lang, Thilo. 2015. "Socio-Economic and Political Responses to Regional Polarisation and Socio-Spatial Peripheralisation in Central and Eastern Europe: A Research Agenda." Hungarian Geographical Bulletin 64 (3): 17185. https://doi.org/10.15201/hungeobull.64.3.2.

Lang, Thilo, and Stefan Haunstein. 2017. "Wachsende Regionale Polarisierung in Europa." Nationalatlas Aktuell 11 (8). http://aktuell.nationalatlas.de/ wp-content/uploads/17_08_Polarisierung_in_Europa.pdf.

Loewen, Bradley. 2018. "From Decentralization to Re-centralization: Tendencies of Regional Policy and Inequalities in Central and Eastern Europe." Administrative Culture 18 (2): 103-26. http://halduskultuur.eu/ journal/index.php/HKAC/article/view/162/157.

Loewen, Bradley, and Garri Raagmaa. 2018. "Introduction to the Special Issue: Territoriality and Governance in the Globalizing European Eastern Peripheries." Administrative Culture 18 (2), 89-101. http://halduskultuur. eu/journal/index.php/HKAC/article/view/175/156.

Massey, Doreen. 1993. "Questions of locality." Geography 78 (2): 142-49. Nagy, Erika, Judit Timár, Gábor Nagy, and Gábor Velkey. 2015. "The Everyday Practices of the Reproduction of Peripherality and Marginality in Hungary." 


\section{In Understanding Geographies of Polarization and Peripheralization:} Perspectives from Central and Eastern Europe and Beyond, edited by Thilo Lang, Sebastian Henn, Wladimir Sgibnev, and Kornelia Ehrlich, 135-55. New Geographies of Europe. Basingstoke: Palgrave Macmillan.

Neu, Claudia. 2006. "Territoriale Ungleichheit-Eine Erkundung." Aus Politik und Zeitgeschichte 37: 8-15. http://www.bpb.de/apuz/29546/ territoriale-ungleichheit-eine-erkundung? $\mathrm{p}=$ all.

Neufeld, Markus. 2017. "Eine Frage des Maßstabs? Zum Verhältnis von Kohäsion und Polarisierung in Europa.” Europa Regional 23.2015 (2017), 4: 15-29. http://nbn-resolving.de/urn:nbn:de:0168-ssoar-53592-0.

OECD. 2016. OECD Regions at a Glance 2016. Paris: OECD Publishing. http://dx.doi.org/10.1787/reg_glance-2016-en. Accessed 18 April 2018.

Peck, Jamie, Nik Theodore, and Neil Brenner. 2012. "Neoliberalism Resurgent? Market Rule After the Great Recession." South Atlantic Quarterly 111 (2): 265-88. https://doi.org/10.1215/00382876-1548212.

Piattoni, Simona, and Laura Polverari (eds.). 2016. Handbook on Cohesion Policy in the EU. Cheltenham: Edward Elgar.

Pike, Andy, Andrés Rodríguez-Pose, and John Tomaney. 2007. "What Kind of Local and Regional Development and for Whom?” Regional Studies 41 (9): 1253-69. https://doi.org/10.1080/00343400701543355.

Pike, Andy, Andrés Rodríguez-Pose, and John Tomaney. 2017a. Local and Regional Development. 2nd ed. London: Routledge.

Pike, Andy, Andrés Rodríguez-Pose, and John Tomaney. 2017b. "Shifting Horizons in Local and Regional Development." Regional Studies 51 (1): 46-57. https://doi.org/10.1080/00343404.2016.1158802.

Plüschke-Altof, Bianka. 2017. Images of the Periphery Impeding Rural Development? Discursive Peripheralization of Rural Areas in Post-socialist Estonia. Dissertation. Tartu University Press, Tartu.

PoSCoPP-Research Group Production of Space in the Context of Polarization and Peripheralization. 2015. "Understanding New Geographies of Central and Eastern Europe." In Understanding Geographies of Polarization and Peripheralization: Perspectives from Central and Eastern Europe and Beyond, edited by Thilo Lang, Sebastian Henn, Wladimir Sgibnev, and Kornelia Ehrlich, 1-21. New Geographies of Europe. Basingstoke: Palgrave Macmillan.

Raagmaa, Garri, and Dominic Stead. 2014. "Spatial Planning in the Baltic States: Impacts of European Policies." European Planning Studies 22 (4): 671-79. http://dx.doi.org/10.1080/09654313.2013.772730. 
Rodríguez-Pose, Andres. 2018. "The Revenge of the Places That Don't Matter (And What to Do About It)." Cambridge Journal of Regions, Economy and Society 11 (1): 189-209. https://doi.org/10.1093/cjres/rsx024.

Soja, Edward. 2009. "The City and Spatial Justice." Justice Spatiale/Spatial Justice 1 (September): 1-5. http://www.jssj.org/article/la-ville-et-la-justicespatiale/. Accessed 13 March 2018.

Soja, Edward. 2010. Seeking Spatial Justice. Minneapolis: University of Minnesota Press.

Špaček, Martin. 2018. "Multilevel Cross-Border Governance in the CzechSaxon Borderland: Working Together or in Parallel?” Administrative Culture 18 (2): 175-202. http://halduskultuur.eu/journal/index.php/HKAC/ article/view/161/160.

Swianiewicz, Paweł. 2010. "If Territorial Fragmentation Is a Problem, Is Amalgamation a Solution? An East European Perspective." Local Government Studies 36 (2): 183-203. https://doi.org/10.1080/ 03003930903560547.

UN_United Nations. 2015. "Sustainable Development Goals." https://www. un.org/sustainabledevelopment/sustainable-development-goals/.

UNCTAD_United Nations Conference on Trade and Development. 2010. "World Investment Report 2010. Investing in a Low-Carbon Economy." New York: United Nations. http://unctad.org/en/Docs/wir2010_en.pdf.

UNCTAD_United Nations Conference on Trade and Development. 2017. "World Investment Report 2017. Investment and the Digital Economy." New York: United Nations. 
Open Access This chapter is licensed under the terms of the Creative Commons Attribution 4.0 International License (http://creativecommons. org/licenses/by/4.0/), which permits use, sharing, adaptation, distribution and reproduction in any medium or format, as long as you give appropriate credit to the original author(s) and the source, provide a link to the Creative Commons license and indicate if changes were made.

The images or other third party material in this chapter are included in the chapter's Creative Commons license, unless indicated otherwise in a credit line to the material. If material is not included in the chapter's Creative Commons license and your intended use is not permitted by statutory regulation or exceeds the permitted use, you will need to obtain permission directly from the copyright holder.

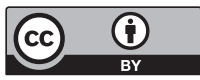




\section{Part I}

Socio-Spatial Polarisation in the EU and Questions of Power 


\title{
2
}

\section{Geographical Uneven Development and Regional Futures: A Conversation}

\author{
Ray Hudson and John Pickles
}

As part of the RegPol ${ }^{2}$ Project "Socio-economic and Political Responses to Regional Polarization in Central and Eastern Europe" Ray and John were invited to hold a wide-ranging conversation about critical economic geography and regional development. The context for the conversation was an on-going research programme involving scholars based in Leipzig and their colleagues interested in the intense processes of regional change in Central and Eastern Europe. The wider project- "Coping with uneven development: socio-economic and political responses to regional polarisation"-focused on two key issues: First, post-1989 political and economic transformation and the emergence of spatially complex forms of representative democracy and economic forms of private instead of state-led markets. Second, the more recent emergence of new forms of social and regional polarisation and

\author{
R. Hudson ( $\square)$ \\ Durham University, Durham, UK \\ J. Pickles \\ University of North Carolina, Chapel Hill, NC, USA \\ (C) The Author(s) 2019 \\ T. Lang and F. Görmar (eds.), Regional and Local Development


the corresponding political renewal of authoritarian state power in several Visegrad countries. We hope this conversation on the theme of contemporary critical economic geography contributes to the broader discussions about post-socialist regional futures.

John: Democratisation, liberalisation and privatisation after 1989 resulted in massive changes in post-socialist Europe. For some, opportunities increased as individuals entered real estate, commercial, and service sector occupations, particularly as state institutions and enterprises were hollowed-out and new management installed. For others, job loss and industrial decline led to regional involution and rapid deepening of social and regional inequalities. Across Central and Eastern Europe the record of the past two decades has thus been highly uneven across national economies and within and between regions. In the past few years, the political consequences of these regional economic transformations, the globalisation and integration of post-socialist economies, and the deepening of fiscal and legitimation crises in the EU and Eurozone have become ever sharper. Regional inequalities, unemployment and precarious futures have deepened experiences of economic marginalisation and social alienation, as shifting patterns of population have deepened xenophobia and petty nationalisms and support for authoritarian populist parties.

In these circumstances, it is no surprise that economic geographers in Central and Eastern Europe have increasingly turned their attention to questions of regional development, economic change, innovation and involution, socio-spatial inequality, and spatial justice. Some have developed and promoted new journals in regional science and regional economics to address questions of efficient resource allocation (see the Hungarian Regional Statistics). Some have focused on institutional and ecological economic geographies (see the Polish European Spatial Research and Policy). Others have focused on the complexities of regional innovation and uneven development (see the Slovak Region Direct). The RegPol ${ }^{2}$ group has taken uneven development, peripheralisation and regional inequality as its primary focus of training, research and publication. It is to this their latest book in this project that we have been invited to contribute a conversation (see also Lang et al. 2015 
and the special issue of the Hungarian Geographical Bulletin Vol. 64 (3) 2015 on "Discussing inequalities from the periphery").

I think it is interesting to note that we each came of age intellectually and politically in parallel contexts to those in the 1960s and 1970s, you in the Northeast of England and me in the Northwest. Each of our home regions was a key centre of nineteenth and early twentieth century industrialisation (the Northeast in coal, steel and shipbuilding, the Northwest in coal and textiles). Each benefitted from post-war regional economic rebuilding underwritten by Keynesian policies and state investments, the expansion of state-owned transport systems, and rapidly improved living standards and expanded forms of social consumption (particularly in health and education). The resulting consolidation of working-class power was - in the 1960s - inflected with new workers recruited from the Caribbean and South Asia and the resulting mobilisation of racialised notions of identity, rights, and entitlements, with different effects on the Northeast and Northwest. With Enoch Powell's articulation of the race card and what it meant to be "British" or "English" there began a long-term organic crisis of the working class, which was rapidly further fractured with Thatcherism and its mobilisation of head-on attacks on trade unions (especially the power of the National Union of Mineworkers) and working-class unity. These conditions and the shifting balance of social forces, in turn, led to a war of manoeuvre on the part of conservatism and business alliances. Mobilising the logics of crisis, Thatcherism launched a head-on attack, first on the National Union of Mineworkers and later on organised labour movements generally. Stuart Hall has called this period "the long march of the Neo-liberal Revolution" (Hall 2011, 1-2) where "open, competitive and unregulated markets, liberated from state intervention and the actions of social collectivities... is the response of a revived capitalism to the crisis of Keynesian welfarism" in the 1970s (Theodore et al. 2011, 15) fused with the evasion of state intervention by "going global”.

Thatcher's rejection of the 'social' as a meaningful category for public policy was underpinned by the idea that the social welfare state's commitment to social and regional redistribution weakened the fabric of individuals and families (welfare cheats, lazy workers, parasitic 
unemployed...) and was the cause of an economic crisis whose solution was a turn to radical individualism and markets. The result was an assault on forms of socialised common-good and the creation of various rounds of sectoral and regional crisis. You felt this directly with the deepening regional crisis of coalmining, steel making and shipbuilding and the rise of unemployment as Thatcherism bit ever more deeply, a crisis that drew university researchers into the domain of public action and economic geographers into the orbit of Marxian analyses of capitalism. For me the parallel experience was of regional crises of coal and textiles in Lancashire, periodic rounds of firm collapse and labour force shedding, and later the deepening regional impacts of racial capitalism in apartheid South Africa and regional economic involution following the collapse of central planning and the imposition of largely unregulated privatisation programmes in Central and Eastern Europe. In each of these cases, we have both been concerned to investigate in various ways the geographies of capitalist transformations and the ways in which they were politically determined, often at institutional levels well beyond the capacity of local communities to control.

This issue has been an abiding concern of your own work and in your 1991 Area paper "The North in the 1980s: new times in the 'Great North' or just more of the same" you addressed it directly by questioning the political role of discourses about regional revival and new times, arguing that state management of the regional economy was not ended by Thatcherism and neoliberalism, but its form of state intervention was changed. The new economy with its emphasis on affluence and housing market growth was, instead, "characterised by a continuing marginalisation of the region relative to the main centres of growth and affluence, both within the European Community and globally" (Hudson 1991, 55). At the time, you saw this form of dependency and marginalisation as "a structural feature of a state-managed region rather than a cultural attribute of its people" (Beynon 2017, 123), and this seems a particularly important and salient corrective to bear in mind when thinking of the contemporary conjuncture in post-socialist Europe, and perhaps Europe more generally.

Perhaps we might usefully begin with these experiences, not to suggest that the processes and patterns of today in CEE were prefigured 
in the UK decades earlier, but to think how the theories and practices of economic geography were developed out of specific contexts and conjunctures in post-war Britain. In them, post-war opportunity and optimism for a new social democratic future quickly deflated as new policies, forms of state action and configurations of political power emerged. Perhaps in these experiences, and in the ways economic geography responded to them, there may be lessons for the ways in which post-socialist economic geographies are experiencing and responding to the intensely uneven experiences of optimism, involution, and illiberalism of the present conjuncture.

Perhaps we can begin with a brief overview of how you came to economic geography, what your initial influences were in choosing that path, and how you see it has changed over the decades of your involvement.

Ray: Surprising as it may seem now, when I first went to Bristol as a geography undergraduate in 1966, I was more interested in physical geography; from what I'd experienced at school, it seemed to offer a more rigorous approach. So much of the rest seemed to be essentially regional description, with very little emphasis on explanation. However, once exposed to the new emerging human geography and locational analysis, with its focus upon the explanation of spatial patterns my interests quickly shifted. Peter Haggett was a wonderful teacher and then of course there was David Harvey, who taught economic geography and a third-year course on philosophy and methodology, which essentially became Explanation in Geography. But even as a third-year undergraduate I was becoming critical of the ways in which economic and social processes were conceptualised within the locational analysis approach, grounded in highly unrealistic assumptions about what people knew and why they made the choices in the economy that they did, and conscious of the need to delve more deeply into the why people behaved as they did. This was the time when behavioural geography was briefly flourishing and my $\mathrm{PhD}$ at Bristol was firmly in this mould. But by the time I was finishing, I was already becoming critical of the way in which the focus on individual decisions in its turn also provided a very under-socialised account of the economy and its geographies. 
So when I moved to a lectureship in Durham in 1972-and became conscious of the dramatic changes that had affected the economy of Northeast England, and the reasons for this-I began to be interested in more political-economic approaches, initially via underdevelopment theories but increasingly via Marxian political economy and the structural and institutional constraints and inequalities in class power that meant that while people made economic geographies, they did so in circumstances that were not of their own choosing. This set me on a path that I followed, with the odd diversion into some interesting culde-sacs, for the last 45 or so years.

John: In 1989, you began Divided Britain with the comment that Prince Charles had pointed to the danger of Britain becoming a divided realm. In the book you and Allan Williams argued that Thatcherism was creating ever deeper divisions among regions and social classes, an almost apartheid-like spatial ordering of the neoliberal space economy with rapidly emerging complex arrangements of new economic spaces and class forces competing with pockets of un- and under-employment across the region. This seems like an ideal opening for our discussion and its relation to this book's focus on regional uneven development and peripheralisation. How did you see this issue of division in Divided Britain?

Ray: From my point of view, Divided Britain was and remains a book very much shaped by the times in which it was written. It was published four years after the miners' strike came to an end, a strike for which the Tories had prepared meticulously when in opposition in the 1970s, had backed off conflict with the miners earlier in the 1980s, holding back until the situation was favourable and then deploying the power of the state to ensure that the miners were defeated. This was savagely demonstrated in the way in which police ran riot through the village of Easington Colliery in the summer of 1984 and most dramatically in the "battle of Orgreave". For once the miners had been defeated and the National Union of Mineworkers marginalised, then the attack on the post-war settlement, on the achievements of what, following Timothy Mitchell (2011), we might denote as a form of "carbon 
democracy", could be pursued with greater vigour as the boundaries of the state were selectively rolled back. One effect of this, coupled with the priority given to financial services and the City of London, was to inscribe regionally uneven development even more deeply into the landscape of capitalism in the United Kingdom as Thatcherism sought to sharpen and re-define socio-spatial divisions within the Divided Realm. It seemed to me important to document this and emphasise the way in which (re)producing socio-spatial division and uneven and combined development was not some unintended by-product but was a deliberate part of a political strategy.

John: Indeed, in the 1980s this notion of geographical uneven and combined development became a crucial concept for critical economic geography more generally. Adapted through various traditions of World Systems Theory, the development of underdevelopment, and dependency theory, Lenin's concept of combined and uneven development seemed to speak to many of us at the time. In particular, it provided a useful framework for breaking free of more traditional concepts of the region as bounded and unique by offering a richer, more political understanding of the relational nature of space and regional change. That the regional problem of, for example, industrial regions had so often been treated as a problem of the region itself, seemed theoretically banal and politically disingenuous. That the regional problem was always a problem of a wider series of spatial policies, processes, and practices was gradually becoming much clearer. Interestingly, in 1985 you published with Jim Lewis Uneven Development in Southern Europe. How did this focus on the economic geographies of southern Europe and the conference on which it was based ('National and Regional Development in the Mediterranean Basin') emerge?

Ray: As you rightly say John, by the 1980s the notion of uneven and combined development had come to occupy a central place in economic geography and some geographers were increasingly seeing regions as a product of both endogenous and exogenous processes; Doreen Massey had a significant influence here. I was also interested in seeing the changes that had occurred in the economy of the Northeast in a 
broader comparative context. Reflecting this, I began to spend time and carry out research in a range of other European regions-for example, regions that seemed to have a similar economic structure to the Northeast of England, such as the Ruhr in Germany, and Lorraine in France-and others that had had very different structures and developmental trajectories - for example, Jutland in Denmark and those regions of Northeast Italy which became known as the "Third Italy". In this context, southern Europe raised some interesting questions, not least because of the political transition from dictatorship to democracy in Greece, Portugal and Spain, and their subsequent entry into the European Community in 1981 and 1986. And other Mediterranean economies had also entered into a variety of trade and labour migration arrangements with Germany and France in particular. As a result, this raised questions for me about how these macro-scale changes in political economies related to changing patterns of uneven and combined development at national and sub-national scales. It was issues such as these that we hoped to explore through the conference and bring together in the book; the more limited focus on southern Europe was very much a reflection of the ways in which the three recent entrants to the European Community and Italy could be seen to share common characteristics but also important differences that reflected the uneven and combined character of development within the larger shared space of the European Community.

John: It is very interesting to me how these two works (one on combined and uneven development in Britain and the second a comparative analysis of uneven development in southern Europe) map out very useful methodologies for addressing the so-called 'regional problem' relationally and conjuncturally. In 1989, in the same year as Divided Britain you published another fascinating book: Wrecking a Region: State Policies, Party Politics, and Regional Change in North East England, in which you turned to the more detailed conditions of regional economic involution that were so deeply affecting the lives and livelihoods of people and places in the Northeast. How did Wrecking a Region with its rich local and contextual analysis come about and why did you 
choose in that book to focus on the role of state policies in shaping regional futures?

Ray: Good question! There is a real sense in which the book is autobiographical. I was born and brought up in Alnwick, a small market town in rural mid-Northumberland, just off the northern tip of the Great Northern Coalfield. My father worked as an electrician at Shilbottle Colliery, just south of the town. So, when I was growing up Alnwick was then located on a sort of cultural divide-mining areas to the south, agricultural ones to the north. Then in 1966 I went off to Bristol University, returning periodically in the university holidays to Alnwick. Over the six years that I was in Bristol, on these return visits I became increasingly conscious of coal mines closing, new factories opening; railway lines and stations closing while new roads opened; town centres ripped apart and then re-built in a very different style, often with new office blocks springing up alongside new shopping centres. There was all too visible evidence that the economy and built environments of the region were changing. All this raised questions about what was going on, and why; and talking to friends over the occasional pint seemed to confirm this sense that things were on the move, though not necessarily for the better. Then in 1972 as a result of a quirk of the academic labour market—and a paucity of available jobs-I was lucky to be offered a job at Durham, back in the region (albeit on the wrong side of that critical cultural divide, the river Tyne, the "big river" that Jimmy Nail was later to celebrate in song). And living back in the region, I became more and more aware of the way in which the region was changing and curious as to why it was changing in these ways. This seemed something that was worth investigating further, a promising new line of research that could have some practical and political relevance in the region.

As I began to research these issues-I was fortunate as a very junior academic to obtain a couple of quite big research grants from the Social Science Research Council and the Centre for Environmental Studies - what quickly became clear was the significance of state policies for the region; in a phrase, it had become a state-managed region. Its industrial economy was dominated by the nationalised coal, steel and shipbuilding industries, while the expansion of the welfare state had 
resulted in education, health care and public administration being the main sources of service sector employment and central to a significant change in the gender composition of the labour force. Put another way, the region, its industries and people had very much become a product of the broader post-war settlement, of the "One Nation" strategy that had been shared by Conservative and Labour governments alike over the post-war period. And it was this of course that Thatcherism sought-and from its point of view, successfully - to destroy. As such, taking apart the nationalised industries and public services that were central to economy and society in the Northeast was in turn central to the Thatcherite project and the region was to be on the front line, disproportionately affected by the transition from a "One Nation" to "Two Nation" strategy (which, as we discussed above, I'd written about more generally with Allan Williams). Focusing on the effects of the changing forms of state policies, of the ways in which nationalisation led to rationalisation, capacity cuts and job losses on a massive scale, and then the privatisation of what was left of those industries that had been at the heart of the regional economy therefore seemed to be important, both intellectually and politically.

John: Interestingly, Wrecking a Region appeared in the Pion Series 'Studies in Society and Spaces' edited by Allen Scott and Michael Storper. The first volume in the series was Mick Dunford's Capital, the State, and Regional Development, Wrecking a Region was the second volume, and Allen Scott's New Industrial Spaces was the third. In various and different ways, each of you were drawing on Marx's critique of political economy to expand the horizons of economic geography. How did you come to enter this scholarly space of economic geography and Marxian analysis? And, perhaps also, what was the specific conjuncture to which your work was responding at that time? What were the particular influences that shaped your thinking?

Ray: As I've sketched out earlier, from the early 1970s I began to get interested in Marxian political economy as a framework in which to begin to understand the uneven geographies of capitalist economies. There were a couple of loose organisational groupings that were important for me in developing my understanding of these issues. The first 
was the Regionalism Group of the Conference of Socialist Economists in the United Kingdom. Participation in this group, which included colleagues from a range of disciplinary backgrounds, became an important source of inspiration and support. Members of the group included James Anderson, Doreen Massey, Mick Dunford, Di Perrons, Gareth Rees, Mike Cuthbert, Andrew Sayer, Nick Rogers, and Martin Boddy. It met fairly regularly and provided a forum in which left-leaning academics could discuss their work and more generally the ways in which the "regional problem" was both changing and being understood in new ways. In addition to, and in parallel with, this, I found engagement with a number of people in Europe-Alain Lipietz, Pieter van Hoogstraten, Viggo Plum, Henrik Toft Jensen and Costis Hadjimichalis, for example-very helpful, as was the influence at a distance of David Harvey. This European context opened up literatures of which I'd previously had little knowledge-for example, German state theory, and Italian social scientists studying uneven development in Italy-and perspectives that were both cross-national and cross-disciplinary. In the 1980s the establishment of the "Seminars of the Aegean" provided an important ongoing forum in which these issues could be discussed further. The seminar met every two or three years on various Greek Aegean islands and provided a very positive, constructively critical cross-disciplinary and cross-national cultural setting that brought together a range of leftist academics, predominantly drawn from Europe and with occasional visitors from across the Atlantic such as Ed Soja and Dick Walker. Regular participants included Costis Hadjimichalis, Dina Vaiou (who, with other Greek colleagues both committed a great deal of their time to the organisation of the seminars), Lila Leontidou, Lois Labrianidis, Maria Dolors Garcia Ramon, Vicente Granados, Giacchino Garofoli, Enzo Mingione, Enrico Pugliese, Alain Lipietz, Henrik Toft Jensen, Viggo Plum, Mike Edwards, Mick Dunford, Jim Lewis, Di Perrons and Andrew Sayer. Some of us also became involved in European Community ERASMUS networks.

John: Given the importance currently placed in European universities and funding agencies on research networks, these earlier collaborations and exchanges are important to know about. The period certainly was an exciting one as the European Left struggled with the growing 
consolidation of neoliberalism and its attacks on organised labour and the wider gains of socialism and social democracy. You take this on directly in your writing, which is clearly grounded in a deep commitment to what might now be called variously 'activist' or 'engaged' scholarship and grounded research methodologies, particularly around the miners' strikes and the struggle with Thatcherism.

Ray: Yes, the miners' strike of 1984/1985 had a very important longerterm consequence for my work. Because a growing shared interest in the future of deep coal mining in County Durham, and the threat posed to this by the Thatcher government, led me to begin to work with Huw Beynon, a collaboration that has now continued over almost four decades and given rise to a number of joint publications (for example, see Beynon et al. 1991). In the years leading up to the strike, Huw had been both researching and working with the Durham Miners Association and he became actively involved in the strike itself. In parallel I was working with Easington District Council to demonstrate the implications of closing collieries and the loss of jobs from mining on the labour market in Easington. This covered the costs of job loss in terms of increased public expenditure on welfare, but also the less tangible costs to individuals and to communities in terms of family break-up, social dislocation, growing problems of mental health and so on. We produced a major report, Undermining Easington, which became the focus of a televised party-political broadcast by the Labour Party. Along with other research, this led to my involvement as a Special Advisor to the House of Commons Select Committee on Coalfield Regeneration and as Special Advisor to a National Audit Office evaluation of the regeneration programmes. There's one more thing worth adding at this point. In the early 1980s Huw and I had both come to the conclusion that there was a clear link between the expansion of private sector opencast mining in Durham and the closure of the nationalised deep mines and this led to a further major research project on the expansion of opencast and its effects (see Beynon et al. 2000). And we continued to document the longer-term effects of the closure of the mines and this will be the focus for our next book (Beynon and Hudson 2019). In all of this we have worked closely with a succession of research students 
and researchers, involving the residents of the former coal districts and the miners' unions, and involving both local residents and former miners as researchers.

John: As we have seen, in your research and writing from the 1980s and 1990s you were closely involved in analysing the complex relationships between local and national struggles over public policy and regional development. By the early 2000s your work seems to have changed its tone and focus a little. Here 'place' seems to have become more central, at least in framing the titles of your writing. For example, in 2000 you published Production, Places, and Environment: Changing Perspectives in Economic Geography and in 2001 your Producing Places was released. Did this use of 'place' as a central concept reflect important shifts in your thinking and engagement with economic geography at the time? I wonder how you see the relationship of place as a political object, as well as an object of theory and analysis, to your earlier concerns with the future of regions?

Ray: There is a sort of connection between those two books, as the first was essentially a collection of previously published work while the second was an attempt to provide a new and more thorough statement of the way I was seeking to understand economic geographies. And as I made clear in the Preface to Producing Places, it can also be seen as developing ideas that were rather briefly stated in the Preface to Wrecking a Region. There was a deliberate sense of ambiguity in the title of Producing Places, focused on the meaning of "place". On the one hand, it referred to those places in which the activities that constitute the economy are performed (factories, offices, shops, homes and so on) and the ways in which these places fit into technical, social and spatial divisions of labour, within and across both private sector companies and public sector organisations. Secondly, however, it refers to the production of "places" as located at the intersection of realms of use values and exchange values. In these places capital—supported directly and indirectly in a variety of ways by the state - seeks to produce profits via the exploitation of labour but these are also places defined by the fact that people live there beyond their existence merely as the providers of the 
commodity labour power. They are socialised human beings, with a variety of attachments and ties to their place, to other people and other places. As a result, places are porous, constituted via the interplay of endogenous and exogenous processes, and are always reproduced in precarious conditions, as the requirements of capital and states on the one hand and people in their place on the other can become dislocated and come into conflict. This became very clear in the strikes in the French steel industry in the early 1980s and in 1984/1985 in the miners' strike in the United Kingdom, for example. Put another way, the institutions and mechanisms through which places are reproduced as such are a matter of some political importance. However, as Raymond Williams made clear, moving from place-specific "militant particularisms" to more broadly-based political movements can be problematic and one consequence of this is that "places" can be drawn into conflict and competition for investment and jobs, often as a result of local or regional alliances between the institutions of capital and labour, dividing the working class on the basis of place.

There's one more thing I'd mention about Producing Places, however, which is an explicit recognition that economic activities always involve material transformations, relations between the social and natural as well as the social and spatial. Given the empirical focus of a lot of my research-on the coal, chemical and steel industries for example, industries in which the chemical and physical properties of material and products was critical in the production of use values, and hence exchange values - this was something I felt had been rather neglected to that point in my own work and by most economic geographers more generally. To put it simply, coal is far from being a homogeneous substance, with a variety of chemical and physical properties that constrain its uses, while the steel produced for car bodies is very different to that produced for the working parts of engines. And these differences matter. Although what I had to say about these issues there was limited, it did point to one direction in which my work would extend more deeply in future-and also suggested that economic geographers interested in these issues would need to engage seriously with work in the natural sciences to understand processes of material transformation. 
John: Following along this line of thinking about the changing concepts and forms of inquiry in economic geography, I was intrigued and excited by your 2005 Economic Geographies: Circuits, Flows and Spaces. My own work in socio-spatial theory, political economy of development, cultural studies, and post-socialism has been heavily influenced by Althusserian Marxism, Foucauldian genealogy, the diverse and alternative economics projects of JK Gibson-Graham, David Ruccio, and others, and the development of Gramscian conjunctural analysis in the cultural studies of Stuart Hall, Doreen Massey, Larry Grossberg, and John Clarke among others. From these perspectives, the analysis and diagnosis of the regional problem of inequality and peripheralisation requires a complex articulation of forms of over-determination, relationality and context that is both economic, cultural, and political. This was the project of my book with Adrian Smith and colleagues (Articulations of Capital and earlier with Theorizing Transition and Environmental Transitions). Your Economic Geographies is fascinating in this sense because of its open view of the field. It is organised around a series of shifts in emphasis occurring at the time from economic geographies of production to the ways in which geographers were focusing on patterns of consumption, nature, and culture in economic life. Here explanation grounded in socio-spatial relations of production are reworked into a fascinating and pedagogically useful framing of the thoroughly complex, contingent, and over-determined nature of economic life. These currents opened up some sharp engagements among various readings of economy, class, and identity among political economists. Yet you seem to have always risen above those fractures and often sharp engagements. At the time, how did you navigate these wider currents changing the kinds of questions about the region, place, and politics that had so infused your earlier work?

Ray: Well to some extent Economic Geographies can be read as seeking to fill in some of the gaps in Producing Places, and in so doing to engage with new and emergent strands of economic geography. Even before the publication of Producing Places, I had become increasingly aware of three related areas of development in economic geography and, in some respects, in the social sciences more generally. First, there was an 
increasing interest in consumption (or perhaps more accurately in many cases, the moment of sale and the realisation of surplus value embodied in commodities), complementing the emphasis in much earlier work on production and the labour process at the point of production. Secondly, something I'd recognised and begun to register, albeit inadequately, in Producing Places, a growing interest in the grounding of the economy in nature and the centrality of relations between ecology and economy (or perhaps better, economies). And thirdly, a growing interest in cultural approaches to understanding economic geographies, which were seen as offering alternative "bottom up" approaches to the variety of "top down" political economy perspectives that for the previous two or three decades had been dominant (and on which I had drawn heavily in Producing Places). These developments raised some intriguing questions for me.

In part, this was because in various ways they took me back to much earlier work. My PhD thesis, for example, produced in the dim and distant past environment of behavioural geography, was very much concerned with how consumers made choices about which shops and shopping centres to patronise, and how they learned about the retailing environment. Much of my subsequent research had in one way or another focused on the geographies of the coal, chemicals and steel industries, each of which in its own way raised important questions about the materiality of production and the relationships between economy and environment, as I indicated above. But more fundamentally, these developments revived important theoretical questions about understanding the totality of the production process in capitalism, the links between processes of production, exchange and consumption and their relationship in socio-spatial divisions of labour and their significance for the process of capital accumulation.

What I was seeking to do in Economic Geographies was to develop a more nuanced approach, drawing upon a range of theoretical perspectives, that allowed economic geographies to be explored in a number of registers and draw upon political economy and cultural perspectives as complementary, while holding on to the established strengths of political economy perspectives. In many ways it can be seen as an attempt to return to the traditions of political economy prior to the neo-classical 
marginalist revolution, which reduced economics to an arid technical exercise in mathematical modelling of the patently unrealistic, and to reconnect analyses of production, exchange and consumption, sensitive both to the cultural construction of economies - the constitutive activities of which are always meaningful and intentional, although with effects that are not always those intended-and the material grounding of the economy in the natural world.

John: I find the centrality of this concept of the cultural construction of economies to be a productive one, in part because it means that we can no longer 'simply' read off the politics of a group from its economic or class position. This was the great challenge facing political economy grounded as it was in earlier assumptions of productivism and very particular conceptions of class. Engaging with the multiple ways in which people construct their relationship to economic and political issues is one of the abiding strengths of critical geography, although its success remains a question for many. I think the concepts of cultural construction, intended and unintended consequences, and materiality help a great deal in opening up what contemporary economic geography might mean.

A crucial form of such grounded materiality is, of course, embodiment. The struggle of the miners was often, and perhaps always about the integral relations of the body of coal and the body of the miner; one torn out of the earth to create use value, the other wracked to create surplus value. These two forms in turn contributed to a wider embodiment and gendering of the family. In my own home region, the mould of mining family structures was, to some extent, reworked as women found employment in textile factories. Linda McDowell and Doreen Massey have written wonderfully about the consequences of this gendering of work and space and for the differential politics of Thatcherism among working-class men and women and feminist geographers, in particular, have opened up questions of how agency and power are understood in economic geography (McDowell and Massey 1984; McDowell 2004).

Another fundamental shift that was taking place in the Northeast and Northwest was, of course, expanded immigration. From the 
$1960 \mathrm{~s} / 1970 \mathrm{~s}$ on increased numbers of immigrants arrived in the Northeast from the Caribbean and in the Northwest from South Asia. My initial teenage experiences of the resulting regional and cultural politics were focused mostly on the pleasures of popular culture, the music of Motown and Northern Soul, struggles of the American Civil Rights Movement, national media and political closure around the claims of anti-colonial liberation movements and the population of radicalism following the worldwide events of 1968. The lasting effects of these and subsequent cycles of immigration have, however, been very different from those we hoped for as white working-class attitudes have hardened and social and urban lives have become deeply segregated. I left Britain in the 1970s but I have returned regularly and often. Over this time, and while some parts of British life have become more diversified and cosmopolitan, in the Northwest the racialisation of space and divisions between communities have deepened. White working-class attitudes towards internationalism and solidarity, once strong in a region where the Suffragette Movement and Independent Labour Party took root early, seem to have given way to Little Englandism, xenophobia, and deep social rifts.

Ray: Coming from a mining background, I'd always been conscious of the relationship between the embodied work of male miners underground-work that was dangerous and that all too often led to fatal accidents — and the domestic labour of their wives and daughters in the home that was crucial to the reproduction of the mining labour force. In families in which both fathers and sons worked on different shifts in the collieries women could be involved in a constant round of providing hot meals and hot water around the clock because of the nature of shift working underground. The unpaid domestic labour of women was crucial in sustaining this. Family life and the social fabric of the mining communities became structured around the sound of the hooter signalling the start and end of shifts. But at the same time the critical social institutions - the trade union, the Labour Party and the working men's clubs - were dominated by men. Quite a few clubs wouldn't let women through the door, and in those that did they were confined to a particular room. So there were tensions, and it is important to recognise 
this. But as became clear in 1984/1985, a year in which many women became heavily involved in supporting the strike, they were prepared to fight in defence of their place. One of the consequences of the events of that momentous year is that a number of women became politically active in the former mining communities, as well as many more becoming the main wage earner in families in which redundant miners became part of the long-term unemployed. In these ways, gender relations both in the home and community became changed in important ways across the former coalfield communities.

I think the issue of ethnicity and race worked out rather differently in the Northeast as compared to the Northwest. There were certainly immigrant communities in parts of Tyneside and Teesside, long-established and linked to the maritime history of the riverside conurbations, but more generally the region was relatively unaffected by the waves of immigration from the Commonwealth. There were certainly some wellknown West Indian cricketers who were recruited by local league teamsRohan Kanhai for example at Ashington (incidentally, once the world's largest coal mining settlement, and the place where my father's family came from)_but by and large the region remained one dominated by the white English. This, coupled with an industrial past that was often linked to producing the means of destruction that were central to the politics of the Empire - guns and warships and so on-did have an effect on the nature of politics, on the character of the Labour Party and its domination by a socially conservative Labourism, and in places on the development of a regressive nationalism-one expression of which was the vote to leave the European Union in the referendum in 2016, in places with little experience of immigration but in which people nonetheless expressed fears of waves of non-existent immigrants taking their jobs ....

But one of the implications that I drew from all this in terms of how we should think about economic geography is that it needed to take on board these ethnic and gender differences and effects in the way that it understood the formation of identities and their relation to more structural understandings of class position as well as the economic and social restructuring of regions like the Northeast and divisions within the working class more generally. I began to explore some of this in Producing Places in a preliminary way. 
John: You revisited these themes in your 2005 Antipode Lecture to the RGS/IBG where you frame the notion of a "pluri-theoretical" geography while arguing for the continued importance of Marxian approaches. Critical economic geography in Central and Eastern Europe has several challenges in taking on-board such a critical pluri-theoretical approach. First, it has had a very different experience of Marxism through Marxism-Leninism of a very particularly state socialist or state capitalist form. Here, neoliberalism was initially, and perhaps today still is, embraced for the political power of liberalism in confronting authoritarian politics, whether of a state socialist form or an unregulated, mafia-oligarchic capitalist form. Second, in the early years following 1989 regional science and locational analysis emerged as particularly important forms of economic geography because of their perceived 'clear' value for state planning agencies in transitioning centrally planned and collective infrastructures to emerging market-based private property regimes. In your various engagements with post-socialist scholars, how have you come to deal with the ways critical thought is situated and inflected differently? Or perhaps more concretely, how do you see Marxian approaches contributing to the analysis of uneven development and peripheralisation with the space economies of post-socialist Europe? What is Right about keeping Left in this context?

Ray: This is a tricky one, especially in conversations with those who were subjected to, as you nicely put it, "Marxism-Leninism of a particularly state socialist or state capitalist form". So, at the risk of repeating myself, I would continue to argue that Marxian political economy is fundamental to understanding uneven and combined development in capitalism. As with other regions in (so-called) "emerging economies", this is the case for those parts of Central and Eastern Europe that are being incorporated into the dominant circuits of capital, a process which is transforming their economic landscapes, inscribing new forms of uneven and combined development, and in some ways reinforcing existing ones. Marxian political economy is the only perspective that seeks to develop a holistic conception of the way in which capitalist economies are constituted and change, structured around the capital-labour class relation, and that allows a rigorous specification of 
the structural parameters of capitalist social relations. That said, let me make a couple of qualifications. First, capitalism now is very different to the capitalism that Marx was dealing with in the middle of the nineteenth century, and indeed from the capitalist world that Lenin and Luxemburg analysed in the early decades of the twentieth century. And as we've discussed above, in the latter decades of the last century, there was a significant shift in the advanced capitalist world from social democratic to neoliberal forms of regulation and capitalist (dis)organisation. As a corollary of such transformations in the character of capitalism, it is necessary to develop modes of analysis that are sensitive to and can deal with such variation, with what have become referred to as "variegated capitalisms", while recognising that these continue to be forms of economy grounded in the fundamental class relations of capital. So, reflecting this, I do not see Marxian political economy as a fixed dogma but rather as an evolving, analytically powerful, conceptual framework that allows the changing character of capital accumulation and capitalist economic geographies to be grasped and understood. Put another way, it is to see Marxian political economy as something that needs to be worked upon and worked with-as David Harvey has brilliantly demonstrated. That said, I would also argue that other perspectives, such as those of feminism, and other political economy perspectivesevolutionary and institutional economics, for example - can complement Marxian approaches, since they focus on aspects of how capitalist economies develop and function, but it is only Marxian political economy that has the question of why they develop as they do at its heart. I've explored some of this further in a more recent book, Approaches to Economic Geography: Towards a Geographical Political Economy (2016).

John: The value of linking Marxian analysis to pluri-theoretical traditions and diverse concepts of space and economy is also the theme of your engagement with networks, regional development and democratic control with Costis Hadjimichalis (Hadjimichalis and Hudson 2006). I think our readers might first be interested in learning a little more about your collaboration with Costis and the kinds of linkages there are between your work and his on regional development and political economy. Second, I want to ask about how this concept of regionally 
embedded networks and urban and regional policy networks might operate as a useful analytical tool for thinking about the contemporary conjuncture in post-socialist societies. We have already talked a little about relational concepts of space. Here relationality is mobilised through a slightly different term or metaphor and perhaps to a distinctly political intervention in policy development, particularly as such networks "deny their constitutive inequalities, asymmetries and democratic deficits" (Hadjimichalis and Hudson 2006, 858).

Ray: Well I've known Costis for well over thirty years and we've worked together at various times over those years. There are a couple of things that I think are particularly significant about his work. First of all, he has always had a political view of Marxian political economy. Secondly, a concern with differing forms of uneven development has always been central to his work. And thirdly, he has a deep grasp of the specificities of uneven development in the context of southern Europe. Thus, in many ways, although the empirical foci of our research have been quite different, conceptually we share common ground, which opened up opportunities to collaborate and bring together work on the connections between uneven development in the 'north' and 'south' of Europe. As the quotation above makes clear, we share a healthy scepticism about the claims being made for networked approaches to regional development in the peripheries of Europe, in particular the way in which-along with much of the rest of the 'new economic geography'-they erase a concern with inequalities in power which we would see as central to capitalist economies. So in response to your specific question about how such concepts of urban and regional policy networks might be used for thinking about the contemporary conjuncture in post-socialist societies, my response would be: "if you use them at all, do so very carefully and cautiously. But in fact, you'd be better off not using them at all, because of the risks of amplifying rather than narrowing socio-spatial inequalities in pursuit of allegedly but in practice unattainable win-win outcomes".

John: Thinking of Costis and networks reminds me that you and he were involved in one of the first Erasmus networks in 1983, initially 
with Durham, Roskilde and Thessaloniki (Hadjimichalis 2017, 126). We have both long held strong views on the importance of collaboration with colleagues across the region and have made many commitments to building collaborative networks and publishing with them. In the face of increasing pressure on younger scholars to publish in Tier 1, often English-language journals, and to focus more and more on single authorship, this commitment to collaboration and co-authorship is ever more difficult in post-socialist academies. I wonder in what ways you might see the Erasmus experience and the subsequent collaborations with colleagues across Europe to have methodological lessons for the practice of contemporary critical economic geography?

Ray: I've already alluded to the importance of the links I developed with colleagues in Europe in the 1970s and 1980s, and the ERASMUS networks in which quite a few of us became involved-I think by the mid-1990s there were around 25 of us involved in the biggest of these-were very important in extending our collaborative work beyond research into education and teaching. As well as allowing students to study in different European countries, to experience often radically different styles of learning and teaching, it also allowed staff-especially those at or near the start of their careers - to get experience of life in universities in other countries and to form collaborative links with colleagues there-which of course often developed to include joint research. I think this was quite important in creating the sort of network that is valuable to those of us interested in developing understanding of the varied geographies of capitalisms. I think it is also fair to add that while these were schemes funded by the European Community, and many of us shared a commitment to Europe (ask me my nationality and the answers, in order, are Northumbrian, European, English ...), this was not the neoliberal post-Maastricht European Union but rather a transformed European Union, one committed to, at a minimum, a social democratic project. It is a matter of some regret that this looks off the agenda for the foreseeable future.

John: The ERASMUS program sought to create new forms of scholarly internationalism as part of the project of building a transnational 
Europe and it began shortly after you published Regions in Crisis. New Perspectives in European Regional Theory. The European project today looks a great deal different than it did in 1980 and 1983, although the analytical focus on crisis may still be a useful one. Recently, you have questioned the project of the EU because it has remained an elitist and top-down project where widening and deepening processes failed to build popular consent. As a result, not only is the EU now seen by some as coercive, competing with national interests, but it has been "a project of and for the political and capitalist economic elites of Europe, creating a new space for capital accumulation and a new political territory that would allow those who rule to have an equal voice with the USA and USSR on the world stage. Put another way, the emergent EU was an expression of a certain class conception of Europe and Europe's place in the world" (Hudson 2017, 139). Here your criticism of the class project of this particular form of 'Europe' perhaps refracts in interesting ways with other possibilities of thinking 'Europe', such as the internationalism of the early ERASMUS networks. Given the apparent deadlock of political forces around the Brexit referendum and the deepening of national antagonisms towards the EU project in other member states, do you see any alternative paths for the reconstitutions of an "other Heading" (as Derrida (1992) suggested) or an 'After Europe' (as the Bulgarian Ivan Krastev [2017] has argued).

Ray: Well, the short answer is that I'm afraid I see no scope for optimism here. There was a time when it did seem that there was scope for some optimism but the way in which the European Union has developed post-Maastricht has put an end to that. The creation of the euro and Euroland, with the fraudulent construction of statistics to enable economies such as Greece disastrously to join, dominated by a monetary policy that is de facto that of the Bundesbank, deeply engrained in an ordoliberal view of the policy world, is guaranteed to reproduce heightened forms of uneven and combined development in the shared European space, especially between the national economies and states of 'north' and 'south' and 'east'. The European Union is trapped between the aspirations of political and economic elites for further political integration driven from the top down and growing resistance, much of it 
framed within regressive right-wing nationalisms and regionalisms that seek to assert older political rights. As such, it staggers from crisis to crisis, with the Brexit episode providing a focus around which the remaining member states can for the moment agree. But once the UK leaves-assuming it does-then the tensions among member states around other issues will re-surface with a vengeance. In the absence of a democratic mandate from the citizens of Europe, further attempts at political integration seem doomed to failure-and so does any realistic prospect of a more socially and economically progressive vision of Europe.

John: In the light of the Brexit referendum, Scottish independence possibilities, and the deepening of the North-South divide with the continued growth and dominance of London and the Southeast, I wonder how you might conceptualise Divided Britain, Wrecking a Region, or Producing Places were you to write them today?

Ray: Interesting question! Huw Beynon and I are just finishing a book that argues that the Brexit vote in the coalfields of Durham and South Wales represented the end-point of a long historical process. To put it very briefly, while nationalisation in 1947 seemed to be a great victory for the coal miners and the coalfield communities, the subsequent reality proved very different. By the 1960s hundreds of collieries were closing and miners were losing their jobs in large numbers. But there did seem to be a political commitment from the Labour government to attract alternative jobs to the coalfields. After a brief period in the 1970s when it seemed coal again had a bright future, the election of the Thatcher government in 1979 made it very clear that this was not the case. While the redundant miners and those living on the former coalfields had little expectation of help from the Tories, they did so from Labour, not least because of the historical links between the Labour Party and the mining unions. Consequently, when it then became clear that Blair's New Labour had simply adopted the economic policies of the Thatcherite Tories, a deep disillusionment both with New Labour and with party politics irrespective of party developed on the former coalfields. The experiences of austerity under various governments after 
the global crisis of 2007/2008 simply reinforced this view. People felt powerless, their needs ignored, disillusioned with the politics of representative democracy as falling participation in elections revealed. As a result, when the opportunity to stick two fingers up to the political system came for the first - and only-time with the Brexit referendum, the view of many was "well, if the politicians think it's a good thing, then let's vote against it". The argument from the Chancellor of the Exchequer, George Osborne, that leaving the European Union would put what you had at risk cut absolutely no ice with people who saw themselves as having lost all they had many years ago. Given all this, any analysis of uneven and combined development in the United Kingdom today would have to start from a recognition of deeply engrained socio-spatial divisions at multiple spatial scales, of decades of economic and spatial policies that have reinforced this, of a context in which there is deep distrust of politicians of all parties, and with the United Kingdom's position in the global as well as European economy in doubt. While the decline of financial services in the City of London might reduce some socio-spatial inequalities, it would be in the context of a weakened national economy as for all the talk of re-balancing the economy, sectorally and spatially, there has been scant evidence of any revival of manufacturing or of the narrowing of socio-spatial divisions. Indeed, Brexit would be likely to see further deindustrialisation as capital re-locates in response. However, in terms of seeking to understand how and why this has come about, a starting point in Marxian political economy would be at least as important as when I first wrote those books.

John: This last series of exchanges leads me to think about engaged scholarship and the relationships between research, policy, and politics. Perhaps more than most economic geographers, you have taken your scholarly work into regional and national organisations, as well as into university administration. I think of Doreen Massey who exemplifies the former and perhaps Nigel Thrift the latter. You have done both and I wonder what this means for how you have come to understand the value, and perhaps limitations, of contemporary economic geography in dealing with regional inequalities and possible new futures. 
Ray: I think it'll be clear by now that in the present conjuncture I'm not optimistic about the possibilities for narrowing regional inequalities in the UK. There has been quite a lot of talk at various times about spinning out intellectual property from university scientific research as the basis for innovative new high-tech firms that would form the basis of revived regional economies in regions such as Northeast England and South Wales. But while there have been occasional 'success stories'which have been richly rewarding for those academics whose research results have become commodified in this way-overall such developments have had, at best, a marginal effect, a thin veneer drawn over and barely scratching the surface of otherwise depressed economies. Of course, whether it was ever sensible to suggest anything other than such an outcome is another question, but many universities seized on the possibility as a way of seeking to justify their existence while regional development organisations were only too happy to cling to this particular straw. That is not to say that university research could not have a positive role in ameliorating the consequences of uneven development and informing alternative development strategies, but this was more likely to be research in the social rather than the natural and engineering sciences and to focus on coping with and adapting to new economic circumstances. Certainly, there could be a role for some sort of economic geography in this, but not those that claim to see the world as one in which a few changes in individuals' attitudes and institutional change at the local and regional level would suffice to guarantee economic regeneration. In some ways the lessons from Marxian analyses of uneven and combined development are painful ones for they make clear that for many places and the people living in them there are no quick and easy solutions - or even slow and painful ones. The reality of capitalist economic development is that it is genetically uneven and combined but what we can learn from the economic geographies of "variegated capitalisms" is that some forms of capitalism are more progressive than others, that some forms of capitalism are preferable to others, and that we should seek to encourage and support these. And my final comment would be this: there is great danger in raising hopes that cannot be delivered, not least as this runs the risk of undermining the democratic process and without the active engagement of people 
in political projects that seek to find new ways of organising economic activities, then economic development will continue to be marked by deep socio-spatial inequalities. Economic geographers-among others-need to engage in the intellectual project of understanding existing forms of uneven development and imagining forms of development that would provide an alternative to these. Economic geography needs to be explicitly a political economic geography.

John: I am sure that this understanding of thinking politically and geographically about the structures of variegated capitalisms resonates clearly not only with British scholars struggling with the United Kingdom's internal and external regional relations, but also with our colleagues throughout Central and Eastern Europe whose own economic geographies have had to adjust to rapidly changing political economies in recent years. They have experienced rounds of intense optimism and pessimism about the efficacy and effects of wildly different forms of regional policy and the consequences each has had for economic development. Ray, it has been a pleasure to discuss these matters and I hope our time here contributes usefully to those ongoing conversations.

\section{References}

Beynon, Huw. 2017. "People, Place and Politics: The Anatomy of Dispossession in the Geography of Ray Hudson." European Urban and Regional Studies 24 (2): 122-25. https://doi.org/10.1177/0969776416689225.

Beynon, Huw, and Ray Hudson. 2019. The Road to BREXIT ...

Deindustrialisation and the Destruction of the Coalfields (Forthcoming).

Beynon, Huw, Andrew Cox, and Ray Hudson. 2000. Digging Up Trouble:

The Environment, Protest and Opencast Coal Mining. London: Rivers Oram Press.

Beynon, Huw, Ray Hudson, and David Sadler. 1991. A Tale of Two Industries:

The Contraction of Coal and Steel in North East England. Milton Keynes: Open University Press.

Carney, John, Ray Hudson, and Jim Lewis, eds. 1980. Regions in Crisis. New Perspectives in European Regional Theory. London: Croom Helm. 
Derrida, Jacques. 1992. The Other Heading: Reflections on Today's Europe. Bloomington: Indiana University Press.

Dunford, Michael. 1988. Capital, the State and Regional Development. London: Pion.

European Spatial Research and Policy. An International Journal Concerned with the Problems of Social and Economic Space Organisation at Local, Regional and Supranational Level. University of Łódź and De Gruyter Open. https://www.degruyter.com/view/j/esrp.

Hadjimichalis, Costis. 2017. "Encounters with Ray Hudson: A Very Personal Note." European Urban and Regional Studies 24 (2): 126-28. https://doi. org/10.1177/0969776416689219.

Hadjimichalis, Costis, and Ray Hudson. 2006. "Networks, Regional Development and Democratic Control." International Journal of Urban and Regional Research 30 (4): 858-72. https://doi.org/10.1111/j.1468-2427.2006.00687.x.

Hall, Stuart. 2011. "The Neo-Liberal Revolution." Cultural Studies 25 (6): 705-28. https://doi.org/10.1080/09502386.2011.619886.

Harvey, David. 1969. Explanation in Geography. London: Edward Arnold. Hudson, Ray. 1989. Wrecking a Region: State Policies, Party Politics and Regional Change in North East England. London: Pion.

Hudson, Ray. 1991. The North in the 1980s: New Times in the 'Great North' or Just More of the Same? Area 23 (1): 47-56.

Hudson, Ray. 2000. Production, Places and Environment: Changing Perspectives in Economic Geography. Harlow: Prentice Hall.

Hudson, Ray. 2001. Producing Places. London: The Guilford Press.

Hudson, Ray. 2005. Economic Geographies: Circuits, Flows and Spaces. London: Sage.

Hudson, Ray. 2006. "On What's Right and Keeping Left: Or Why Geography Still Needs Marxian Political Economy.” Antipode 38 (2): 374-95. https:// doi.org/10.1111/j.1467-8330.2006.00584.x.

Hudson, Ray. 2016. Approaches to Economic Geography: Towards a Geographical Political Economy. London: Routledge.

Hudson, Ray. 2017. "Facing Forwards, Looking Backwards: Coming to Terms with Continuing Uneven Development in Europe." European Urban and Regional Studies 24 (2): 138-41. https://doi.org/10.1177/0969776416689230. Hudson, Ray, and Jim Lewis, eds. 1985. Uneven Development in Southern Europe: Studies of Accumulation, Class, Migration and the State. London: Methuen.

Hudson, Ray, and Allan M. Williams. 1989. Divided Britain. London: Belhaven Press. 
Krastev, Ivan. 2017. After Europe. Philadelphia: University of Pennsylvania Press.

Lang, Thilo, Sebastian Henn, Wladimir Sgibnev, and Kornelia Ehrlich, eds. 2015. Understanding Geographies of Polarization and Peripheralization. Perspectives from Central and Eastern Europe and Beyond. New Geographies of Europe. Basingstoke: Palgrave Macmillan.

McDowell, Linda. 2004. "Masculinity, Identity and Labour Market Change: Some Reflections on the Implications of Thinking Relationally About Difference and the Politics of Inclusion." Geografiska Annaler B 86 (1): 45-56. https://doi.org/10.1111/j.0435-3684.2004.00153.x.

McDowell, Linda, and Doreen Massey. 1984. "A Woman's Place?" In Geography Matters! A Reader, edited by Doreen Massey and John Allen, 124-47. Cambridge: Cambridge University Press in Association with the Open University.

Mitchell, Timothy. 2011. Carbon Democracy: Political Power in the Age of Oil. London: Verso Books.

Pavlínek, Petr, and John Pickles. 2000. Environmental Transitions: Transformation and Ecological Defense in Central and Eastern Europe. London: Routledge.

Pickles, John, and Adrian Smith, eds. 1998. Theorising Transition: The Political Economy of Post-Communist Transformations. London: Routledge.

Pickles, John, and Adrian Smith (with Robert Begg, Milan Bucek, Poli Roukova, and Rudolf Pástor). 2015. Articulations of Capital: Global Production Networks and Regional Transformations. London: Wiley-Blackwell. Region Direct. An International Journal Produced in Cooperation with the University of Economics Bratislava and the Faculty of National Economy, the Faculty of Economics Matej Bel University Banská Bystrica, Regional Science and Politics Association, and Regionálne európske informačné centrum Banská Bystrica. Regionálne európske informačné centrum Banská Bystrica. https://www.degruyter.com/view/j/regd.

Regional Statistics. Journal of the Hungarian Central Statistical Office, Budapest. https://www.ksh.hu/terstat_eng.

Scott, Allen J. 1988. New Industrial Spaces: Flexible Production Organization and Regional Development in North America and Western Europe. London: Pion.

Theodore, Nik, Jamie Peck, and Neil Brenner. 2011. "Neoliberal Urbanism: Cities and the Rule of Markets." In The New Blackwell Companion to the City, edited by Sophie Watson and Gary Bridge, 15-25. Chichester: Wiley-Blackwell. 
Open Access This chapter is licensed under the terms of the Creative Commons Attribution 4.0 International License (http://creativecommons. org/licenses/by/4.0/), which permits use, sharing, adaptation, distribution and reproduction in any medium or format, as long as you give appropriate credit to the original author(s) and the source, provide a link to the Creative Commons license and indicate if changes were made.

The images or other third party material in this chapter are included in the chapter's Creative Commons license, unless indicated otherwise in a credit line to the material. If material is not included in the chapter's Creative Commons license and your intended use is not permitted by statutory regulation or exceeds the permitted use, you will need to obtain permission directly from the copyright holder.

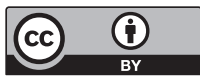




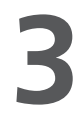

\section{"New" Questions of Peripherality in Europe or How Neoliberal Austerity Contradicts Socio-Spatial Cohesion}

\section{Costis Hadjimichalis}

\section{Introduction}

The European Union during the last 20 years has been suffering from a deep multi-dimensional crisis threatening its existence, a crisis which is a combination of economic, social, political and cultural elements. The years of austerity and the economic crisis since 2009, the undemocratic mode of governance and the revival of nationalistic and xenophobic divisions seem to challenge the promises of unity and cohesion. New inequalities are produced while older ones are intensified, highlighting the never-ending importance of uneven geographical development. In this context, the notion of socio-spatial peripherality acquires a renewed importance, free from older binary and static interpretations.

The context of this chapter is largely based on my book: Crisis Spaces: Structures, Struggles and Solidarity in Southern Europe, London: Routledge, 2017.

C. Hadjimichalis $(\bowtie)$

Department of Geography, Harokopio University, Athens, Greece

(C) The Author(s) 2019

T. Lang and F. Görmar (eds.), Regional and Local Development 
It is widely accepted that the socio-spatial production of peripherality is the outcome of the longue durée of uneven and combined development, deeply rooted in the operation of capitalist market forces. As Gunnar Myrdal noted in the 1950s: “...the play of forces in the market normally tends to increase, rather than decrease, the inequalities between regions" (Myrdal 1957, 26). Different processes of peripherality relate also to how particular places are integrated into the international division of labour and are excluded from each time dominant economic activity. Particular institutional regulations may periodically reduce or reinforce unevenness, but without uneven development, capital would surely have stagnated, as David Harvey (1982) long ago noted. However, unevenness across space and consequently the reproduction of socio-spatial peripherality is not restricted to the needs of capital only. It is combined with the uneven ideological imaginations and with the cultural power that constructs the Other as inferior, with the uneven political power of elites and institutions that impose regulations, and with the uneven conditions of social reproduction in unemployment, education, housing and health, among others.

Uneven geographical development as a framework enables us to approach the social production of peripherality in a dialectical way to avoid a static and binary distinction between cores and peripheries and to see peripherality as a contested concept. For example, remoteness and rurality, two major indicators used by the dominant explanations, do not always lead to peripherality. Rural gentrification and the existence of peripheral/marginal groups and places within wealthy areas of cities and regions, challenge these two major indicators. Many other contradictory and multi-scalar processes produce and reproduce socio-spatial peripherality in the context of international and European division of labour. Among those, I note capital's contradiction between fixity and motion, the relative immobility of labour, the production, circulation and realisation of value, path dependency, place-specific devaluations, cultural prejudices and imaginations and finally, institutions regulating all the above (Hudson 2005). Although these processes are key parameters in the reproduction of peripherality, in this chapter I would like to discuss two other parameters, which in my view are equally important, particularly to the recent European crisis-driven conjuncture. Firstly, how 
imaginations of peripherality shape development theories and policies and secondly, how imaginations and development policies may contribute to deepening unevenness and peripherality. I will conclude by raising some questions concerning the current socio-spatial situation in the EU.

\section{$2 \quad$ Imagining and Conceptualising Socio-Spatial Peripherality}

A key starting point is this: "Who frames capitalist development problems and how?". After the 1950s, international development theories, inspired in part by the problems of the Global South, labelled as "Peripheral" all those countries and regions not belonging to the "northern" birthplaces of European and North American capitalism, labelled as the "Core". Theories such as development and underdevelopment, core-periphery, import substitution, strong state intervention in public infrastructure investments and the like, came from this period. Economists, geographers and sociologists started to use a series of indices such as accessibility and transport infrastructure, income and consumption per capita, capital supply, degree of industrialisation, export performance, illiteracy, etc., to measure the distance between "peripheral" regions and countries, with "core" regions as the norm. Measuring development distance between nations and regions through such indices became the new dogma and "peripheral" in general became the new international prototype of backwardness. International development theories were transplanted to the regional scale in the 1960s and the 1970s and replicated similar assumptions and indices to measure regional backwardness. Since then, "peripheral" in economics, economic geography and regional development theories has become synonymous with underdevelopment. This has resulted in three major theoretical problems, with devastating effects that persist today.

The first concerns the indices themselves. Although they appear as neutral, universal and technocratic, they are deeply biased, based on historically and geographically specific social and cultural experiences and choices. Those who use and apply the measures are mainly from the "core developed" countries and regions, from whence the historical roots of European 
and North American imperialism and industrial capitalism originate. They put forward as a prototype the particular development trajectory of those areas, which is, of course, different from those places in the periphery. "Different" here does not necessarily mean lagging, less important or inferior which are definitions deriving from the vantage point of the dominant formulations imposed by the indices. Measuring development through indices ignores the variety of actual uneven capitalist development, which takes different forms in different socio-spatial formations; what Bob Jessop (2011) called "variegated capitalism".

The second theoretical problem concerns the linear, economistic and universal development trajectory assumed by these indices and by those who use them. At one end stand the "core/developed" countries or regions having the highest or best indices, while at the other end are those "peripheral/underdeveloped" places. The dominant assumption is that "lagging" peripheral regions need to "catch-up" with developed ones and to do this, they need modernisation, outside assistance and a lot of effort. Several decades ago, the economist Charles Kindleberger called this model the "gap approach": you subtract the indices of peripheral regions from the core ones and the rest is your development programme. In this model, there is no option for a different development path, no alternatives, and imagination of the "peripherality" as metaphor has entered a self-reinforcing cycle in which it is stereotyped (Massey 2006).

The third theoretical problem concerns explanations of backwardness and peripherality. Developmental problems in peripheral areas are explained, on the one hand, as solely the outcome of internallendogenous factors, such as remoteness, capital scarcity and inadequate technology and infrastructure. Social and cultural factors were added, with local people accused of being "traditional, lazy, irresponsible and less energetic", fuelling negative prejudices. These explanations ignore inter-regional relations with the rest of the country and the world and interventions by particular states and capital interests. On the other hand, peripherality is explained as the sole outcome of imposed exogenous exploitative relations, such as multinational capital and/or particular institutional interventions by core capitalist countries. The role of local social actors is totally ignored, assuming their passivity. However, uneven capitalist 
development in general and the reproduction of peripherality in particular, depends always on the contradictory articulation between internal/endogenous and external/exogenous factors (Hadjimichalis and Hudson 2007, 2014). Cities, regions and countries are not closed, bounded entities, but are open and porous; their firms, people and institutions interact, building relations at multiple scales, from local to global and vice versa. There is a shifting importance between these conditions, which are always uneven and combined in particular places and times, introducing dynamic characteristics dependent on changes in the spatial division of labour, from global to local.

Following these imaginations and conceptualisations, several policies in the 1960s and 1970s were introduced in the global North, and particularly in Europe, to develop regional peripheries. Among them, I recall the building of traffic infrastructure to challenge remoteness; the construction and operation of social and cultural infrastructures such as schools, universities, hospitals, housing and museums to improve conditions of social reproduction; large capital investments to provide employment in planned industrial growth poles or in industrial branch plant economies and many more. In summary, these policies had in common a strong external/exogenous intervention, either from the state or by private capital. For some time, these policies worked in parallel with the wider compound capitalist growth and did manage to ameliorate conditions of peripherality, a period known as "welfare regionalism" largely based on Keynesianism and social democratic political principles. However, major changes in the European and global division of labour, the collapse of the Soviet Union and the Eastern block, the rise of neoliberalism, financialisation and massive de-industrialisation, all acted as catalysts to show, once again, the impasse inherent in these assumptions.

In the 1980s and 1990s, a major paradigm shift occurred in economic geography and regional development. Parallel to slow compound growth and as a reaction to the inadequacies of exogenous national and regional development frameworks, the focus shifted from lagging peripheral regions to cases of regional success and a new scale was introduced, the local. Regions and localities such as Third Italy in northeast-central Italy, Silicon Valley and Orange County in 
California, the 'M4 corridor' in southern Britain and southern Bavaria in Germany became paradigmatic cases, while subsequent research came to include many more examples in other parts of the world. The new analytical framework, known as the "Third Way" of thinking, was now "endogenous" development, in which small firms in these regions/ localities successfully combined market opportunities, supposedly without external assistance (Hadjimichalis 2006, 2017). They succeeded by mobilising locally existing resources (particularly knowledge and learning) and new forms of production organisation such as flexibility and networking. These new industrial spaces highlighted the role of competition and cooperation at the local/regional level, with the assistance of strong endogenous cultural traditions and local institutions and associations. Researchers and policy makers agree that a distinctive feature of these places and localities is the embeddedness of certain non-economic factors such as social capital, trust and reciprocity, based on familiarity, face-to-face exchange, cooperation, embedded routines, habits and norms.

As is by now well known-and so just briefly mentioned herethis 'Third Way of thinking' is identified with two major schools of thought: first the so-called New Economic Geography (NEG) or "geographical economics" and second, New Regionalism (NR). Without forming a coherent body of theory, NR promotes several proposals for "learning, networked and flexible" regions, "innovative and intelligent" regions, "clusters", "creative" cities, "communicative planning" and the like (Storper 1997; Cooke and Morgan 1998; Healey 1997; Amin and Thrift 2005). They appeared within the panoply of local/regional development theories in the 1980s and 1990s. According to both theorists and policy makers, while in the past local/regional development took place endogenously in a spontaneous manner, now it can be designed to implement a policy "from below". International organisations, such as the OECD, World Bank, European Union (EU) and several national governments initiated programmes to promote such policies, using the aforementioned success stories as "best practice".

Perhaps the most important omission from this research framework and much of the "New Regionalism" literature, which really remains unspoken, is the uneven relations among regions/localities, successful 
and unsuccessful alike; in other words the burning question of uneven geographical development under capitalism. This was evident in how little attention was paid to the capitalist crisis that was already visible from the mid-1990s in some of the emblematic localities and regions. Just at the very moment that policy prescriptions based upon the assumed bases of success in these localities were becoming generalised within regional and urban policies across the globe, the conditions on which success was based in these exemplar regions were being eroded (Hadjimichalis and Hudson 2014).

\section{Imagining Backwardness and Dealing with Peripherality in the EU}

Much of the previous discussion finds application in the different phases of EU regional development policies. From the mid-1960swhen the EC's "regional problem" was for the first time identifieduntil the mid-1980s, peripherality was imagined mainly as inadequate infrastructure, degree of industrialisation, unemployment and lack of adequate income. It guided a modest attempt towards redistributive policies that, together with the highly generous CAP, resulted in differentiated regional improvements, particularly in Southern Europe, France and the UK. During this period, European regional development indices were introduced followed by a European universal development trajectory while there was a relative balance explanation of peripherality between endogenous/exogenous factors (Thoidou and Foutakis 2006). This period coincided with the first signs of de-industrialisation and the rise of neoliberalism, first with Thatcherism in the UK and later with ordoliberalism in the then West Germany. ${ }^{1}$

From mid-1985 to the early 2000s, several enlargements added new members and in all EU documents and declarations there was an explosion of interest in conversion and cohesion. The exact meaning and content of the two new terms were ambiguous and contradictory, because the allocation of more funds to peripheral regions aimed to compensate for the prospective loss of their competitiveness. It was a major change in the imagination and conceptualisation of peripherality, 
introducing directly the neoliberal rationale of "regional competitiveness" deriving from the Maastricht Treaty of 1992. Competition among regions introduced indirectly the endogenous analytical framework. Many concepts of "Third Way" thinking, particularly those of learning, innovative and intelligent regions, made their appearance in policy recommendations.

From the early 2000s to 2014, we lived in the era of the Lisbon Treaty, the enlargement to 28 members and the euro crisis. The Lisbon Treaty contributed directly to weaken the promotion of the, already illfunded, cohesion objective, while the euro crisis and, after 2015, the refugee crisis, changed dramatically what we once knew as United Europe. From a spatial point of view, since the 2000s, regional unevenness in the EU has increased and this increase highly correlates with particular EU policies. During the early euro years, 2000-2013, all development policies of the EU, including regional policies, were subsumed under the Lisbon strategy. It was assumed that Regional Competitiveness, as the main development axis, would provide "growth and jobs". All EU regions became eligible for funding and although extra funding was available for the less developed regions, this policy shift benefited peripheral regions in the East and the South the least, although supposedly, drafted for them. The euro crisis in the regions of Southern Europe and persisting structural deficiencies in many ex-socialist regions of the East fuelled regional divergence during the period 2000-2015 (European Commission 2017). The sequel to this story is Europe 2020, a strategy promoting "smart, sustainable, inclusive growth" (European Commission 2010). By then, everything in Europe was supposed to be "smart" to "improve the business environment". In addition, all policies should follow neoliberal "fiscal discipline" and finally: "Fiscal consolidation and long-term financial sustainability will need to go hand in hand with important structural reforms, in particular of pension, health care, social protection and education systems" (European Commission 2010, 24). In short, austerity.

The major problem with cohesion funds is the contradiction between seeking neoliberal macro-economic policies that impose austerity while pursuing solidarity and economic and social cohesion. The cornerstone of any regional development programme consists of socio-spatial redistribution 
aiming at reducing unevenness and socio-spatial injustices, something that is inconsistent, theoretically and practically, with austerity.

The latter is documented in the 7 th Report on economic, social and territorial cohesion (European Commission 2017) with evidence of economic and social gaps between Southern/Eastern Europe and regions in more developed nations in Northern and Western Europe. Using known indicators such as, among others, GDP per head, general and youth unemployment, education and training, poverty and exclusion, the report highlights the increase in regional inequality in all the above indices during the period 2000-2015, i.e. when neoliberal austerity was generalised across the EU. The Report also identifies four "income clubs": very high, high, medium and low income "clubs" (p. 23). The geography of these "clubs" corresponds to the familiar uneven development pattern, known since the 1990s. Very high- and high-income regions are located in a band from London through Paris, the Benelux and Germany, down to some northern Italian regions and up to Scandinavian regions. Medium- and low-income regions instead are located in Southern and Eastern Europe. General and youth unemployment, poverty and social exclusion show a similar geographical pattern. Furthermore, the EU itself promotes neoliberal policies and, following the new Economic Governance established in 2012, could use cohesion funds as a threat tool, since Brussels is allowed to suspend funding for countries that fail to meet their deficit targets. Thus, it is hardly surprising that after 30 years, regional and cohesion programmes have failed to achieve their main goal: creating a more economically homogeneous Europe. The main reason behind this failure is austerity cutting across all these indicators, depending, of course, on the particular variety of neoliberalism applied in each country.

The 2014 reform of EU Cohesion Policy (EUCP) to strengthen the efficiency of the policy and to increase the performance of the recipient regions, made the whole process more complicated. The three pillars of the new EUCP consist of "smart, sustainable and inclusive growth". The first two pillars of the 2020 agenda are reduced to the goal of regional economic competitiveness, whilst the third requires solidarity among member states and regions in contradiction of the former two pillars. In the post-2014 period, two types of conditionality are in operation. 
First, the macro-economic conditionality operates as part of the Fiscal Pact, imposing economic surveillance of budgetary limitations, i.e. imposing permanent austerity. Second, there will be conditionalities operating inside the context of the EUCP. All countries have to spend allocated funds in two years; otherwise, they must return the money. The reorientation of post-2014 EUCP promotes an endogenous approach that views "region" in functional terms: a bounded entity that determines economic action and every region should "compete" and achieve convergence through growth. A familiar approach that re-introduces endogenous processes also emphasising "Third Way" concepts such as non-economic factors such as knowledge (especially tacit), capacities to generate consensus and trust and social capital, innovative capacities of firms and organisations and high labour skills (Hadjimichalis 2006).

The objectives and discourses of "growth through competitiveness, innovation and flexibility" have superseded the pursuit of cohesion and convergence through redistribution. The Lisbon Treaty and Europe 2020 contributed directly to the weakening of the promotion of the cohesion objective as part of EU policies. Despite the rhetoric in documents and the Brussels jargon, the reproduction of socio-spatial peripherality via austerity and uneven geographical development is alive and well.

\section{In What Sense Peripherality in the Twenty-First Century?}

I borrow the above question from Doreen Massey's late 1970s' seminal paper, where she introduces the concept of spatial division of labour. Among many other points, Massey $(1979,236)$ argued that:

...'The economy' of any given local area will (...) be a complex result of the combination of its succession of roles within the series of wider, national and international, spatial divisions of labour.

The current situation in the various peripheries of Europe, which has stayed more or less stable since the 1990s, strongly depends on the "succession of roles" within the spatial division of labour, from local to 
global, incorporating endogenous and exogenous factors. In this respect, uneven conditions of peripherality in the twenty-first century are hardly "new" and build upon major restructuring processes that have taken place in recent decades. Among these, I can briefly mention the uneven enlargement of the EU towards Eastern Europe; the combination of de-industrialisation and de-localisation of productive activities resulting in unemployment and regional decline in "traditional" agglomerations and the rise of new ones; a massive class, gender, age and ethnic recomposition of the EU labour markets including incoming migrants; several institutional restructurings such as the Maastricht Treaty, trade regulations such as the Outward Processing Trade; and finally, the major financial break with the introduction of the euro. This restructuring in the spatial division of labour resulted in deepening uneven development between and within countries that further marginalised the position of EU peripheries (see also Smith 2013).

As shown in the previous section, regional/local development policies have been inadequate in dealing with peripherality questions. The major crisis of 2009-2010 in Europe and beyond introduced three other important factors visible since the 1990s but acquired critical importance after the global turmoil in 2009. These are: (a) financialisation, (b) the rise of a new rentier economy, and (c) private and public debt that rarely entered the discussion of local/regional development theories and policies. From the late 1980s onwards, financialisation took the lead with the help of active intervention by the state (Hudson 2010; Sayer 2015). The productive sector in EU regions exhibited slow growth, but did so variably between regions, with German regions and their satellites the obvious example. Instead, rent-seeking activities such as investments in bonds and securities, in privatised public utility companies, in insurance and in real estate and land grabbing started dominating EU economies. Deregulation of old welfare apparatuses and re-regulation for the benefits of capital plus technological innovation helped the financial sector to create new "products" and to attract the majority of surplus capital. Moreover, welfare cuts, lower wages and credit card expansion made middle-, working-class households become increasingly dependent on formal finance, and they incurred debt in order to secure access to vital goods. Finally, due to diminishing public 
revenues, states, regions and municipalities began to depend more and more on bank loans or investments in securities to finance their daily operations and to build speculative real estate. Their debt accumulated while financialisation proceeded and in this way, private, public and municipal debt became a mechanism for capturing social wealth and political control. As the French Regulation School and Maurizio Lazzarato argued, it was a major shift in the "regime of accumulation", away from the Fordist and post-Fordist productive regime towards the "regime of accumulation with financial and debt dominance" (Aglietta 2000; Boyer 2000; Lazzarato 2012).

The above shift is highly uneven geographically but reproduces the familiar polarisation in the EU discussed in the previous section. Some regions in central-north Europe retained their productive capacity, exported performance, and accumulated surpluses, while the peripheries of Southern and Eastern Europe accumulated debt. The rise of the so-called FIRE economy (finance, insurance and real estate) increased the importance of metropolitan regions and further marginalised rural peripheries. None of these developments attracted attention and so the crisis of 2009-2010 exploded out of a deep sleep.

In addition, the authoritarian and unaccountable mode of EU Governance facilitated the rise of technocracy that de-politicised all development problems. Since the 2000s, neoliberal and "Third Way" regional development theories and policies operated on the same track so that both promoted policies for a competitive and entrepreneurial city and region. Thus, the way they formulated Doreen Massey's original question "In what sense a regional/peripheral problem" has been de-politicised when a frontal attack against neoliberal policies was needed. The trouble in these times is that most policy makers have no idea who Keynes was and what he really stood for and do not know Myrdal's "cumulative causation" and "backwash effects"; uneven development sounds "too political" while the understanding of Marx is negligible.

So what is the response of the dominant EU institutions to the above developments and critical comments? I am afraid very inadequate indeed. Unable or unwilling to face the results of their own practices, European leaders met in March 2017 in Rome to celebrate the 
EU's 60th "birthday". Among the celebratory speeches and in the Rome 2017 Declaration, three important concepts, the lack of democracy, austerity and the euro crisis, were absent. It is hardly surprising that political leaders had little self-critical to say about the issue. Instead, in classical Brussels' jargon, the Declaration promised that the Union "will act together, at different paces and intensity where necessary". This is how the European establishment covered the proposal for a "multispeed" Europe, launched by German, French, Italian and Spanish elites. The proposal, known also as "variable geometries", "differentiated integration" and "concentric circles" had been around for several years in Brussels and in meetings of experts, but it was opposed by British and some other countries' elites. It has been indirectly included in the Maastricht Treaty, the Schengen agreement and finally in the Eurozone. These agreements gave the power to individual states to join policies and treaties selectively on a voluntary basis and, in combination with neoliberalism and financialisation, made clear that real integration and convergence was not an EU target. Uneven development, covered as always with nice words about social and territorial cohesion, was finally de facto accepted by the EU and silently framed as the deserved price for those not willing to join proposed policies.

We don't yet know the exact ingredients of the new proposal, except that it openly challenges one of the foundational principles of the then European Common Market, agreed in Rome in 1957, namely that all countries are equal. At that time, European integration was a hegemonic project in the sense that the dominant powers promoted their class interests, while looking after the popular masses via social cohesion, redistribution and social welfare. Of course, socio-spatial equality existed only in principle and in the course of time capital accumulation and political intervention (e.g. the Maastricht Treaty and the introduction of the euro) made some countries, regions and social groups within them "more equal" than others. Neoliberalism and its German version, ordoliberalism now dominant in the EU, violently changed the remnants of the old hegemonic project and guided the EU and particularly the Eurozone into crises, ceasarism and austerity. At the beginning of the twenty-first century, dominant class interests still lead the project but without hegemony. The widespread de-legitimisation of EU policies 
that came unfortunately mainly from ultra-right xenophobic political forces and less so from left anti-systemic movements and parties is indicative of the present condition.

In the 2017 celebrations in Rome, inequality and uneven development were cynically packed in fancy wrapping and offered as the solution to the EU malaise, as a positive new paradigm supposedly facing forwards while refusing to look backwards that is, without "coming to terms with continuing uneven development in Europe", as Ray Hudson (2017) argues. Some of the Heads of State supporting the idea argued that "multiple speeds already exist in Europe", and Angela Merkel added, "we cannot stop countries wishing to increase their speed of integration". Their cynicism is blind to the fact that the enterprise of European integration, instead of moving at multiple speeds, is at a standstill, or worse, in reverse. Furthermore, it is not accidental that EU leaders and the class interests they represent avoided coming to terms with the existing undemocratic EU structure. In the Rome Declaration, they promised to "promote democratic, effective and transparent decision-making" in clear contradiction to the acceptance of Treaties and the practices of EU institutions responsible for applying undemocratic and opaque procedures.

I am aware that the current elitist ruling order in Europe and the stock of regional development policies they use are incapable of dealing effectively with these issues and of restoring confidence and solidarity among sharply divided populations. Therefore, a major political change away from neoliberalism and austerity is needed as the necessary precondition, but perhaps is not enough to handle the "new" questions of peripherality. Thus, besides much-needed macro-political changes, I propose to look also inward, into our field. Much contemporary regional development theory and policy were crafted in the 1990s, a period of relative stability, integration and growth that ended in economic crisis and high uncertainty. Existing mainstream theories and policies are weak and proved incapable of explaining these conditions and this demands fresh thinking. So, a paradigm shift is required, one that goes back to earlier political economy theories and policies, avoiding mistakes of the past; and one that looks forward integrating lessons from the euro and the refugee crisis and the effects from austerity policies. ${ }^{2}$ 
The previous critical comments could be seen as an invitation to start thinking towards the required shift, in which we should fight to repoliticise regional development issues by asking who is gaining/losing and why, because neither success nor failure is entirely endogenous or exogenous. In other words, if a region fails it is not only of "its" own endogenous problems but it is also part of the price of others "succeeding" to become centres, materially or imagined. We should also pursue policies and actions that challenge socio-spatial injustice and the lack of democracy and accountability, both at home and in EU institutions. These steps by themselves cannot challenge the neoliberal dogma, but at least could open new paths of knowledge and emancipation, so important nowadays for younger researchers and policy makers. Not an easy task but one worth the effort. After all, experience tells us that lost fights are only those that were not fought.

\section{Notes}

1. Ordoliberalism became the dominant mantra of law and order in Germany after the 1980s and was characterised by the following features: strong central state intervention to secure competition; an independent central bank committed to monetary stability and low inflation; a balancing of tax revenue against government expenditure; privatisation of public services and public assets; deregulation of the labour market and putting in place a minimum wage. The State is necessary to achieve the market ideal, but a particular kind of State. Ordoliberals have limited faith in democracy and instead they strongly believe in independent, networked institutions that are unaccountable and operate parallel to the State. The trouble with ordoliberalism, as Aziz (2015) notes, is that when situations/basic parameters change, the rules of independent institutions stay the same, and if that means the problem is not solved, then so be it. This is how the EU and Eurozone operate nowadays.

2. For reason of space, I cannot explain here further the requirements of this shift, but the interested reader should consult Hadjimichalis and Hudson (2014) and Hadjimichalis (2017). 


\section{References}

Aglietta, Michel. 2000. "Shareholder Value and Corporate Governance: Some Tricky Questions." Economy and Society 29 (1): 146-59. https://doi. org/10.1080/030851400360596.

Amin, Ash, and Nigel Thrift. 2005. "What's Left? Just the Future." Antipode 37 (2): 220-38. https://doi.org/10.1111/j.0066-4812.2005.00488.x.

Aziz, John. 2015. “The Trouble with Ordoliberalism.” Pieria, July 29. http:// www.pieria.co.uk/articles/the_trouble_with_ordoliberalism.

Boyer, Robert. 2000. "Is a Finance-Led Growth Regime a Viable Alternative to Fordism? A Preliminary Analysis." Economy and Society 29 (1): 111-45. https://doi.org/10.1080/030851400360587.

Cooke, Philip, and Kevin Morgan. 1998. The Associational Economy: Firms, Regions, and Innovation. Oxford: Oxford University Press.

European Commission. 2010. "Europe 2020: A Strategy for Smart, Sustainable and Inclusive Growth." COM (2010) 2020 Final. Brussels: European Commission. http://ec.europa.eu/eu2020/pdf/COMPLET\%20 EN\%20BARROSO\%20\%20\%20007\%20-\%20Europe\%202020\%20 $-\% 20 \mathrm{EN} \% 20$ version.pdf.

European Commission. 2017. "My Region, My Europe, Our Future. Seventh Report on Economic, Social and Territorial Cohesion.” Luxembourg: Publications Office of the European Union. http://ec.europa.eu/regional_ policy/sources/docoffic/official/reports/cohesion7/7cr.pdf.

Hadjimichalis, Costis. 2006. "Non-economic Factors in Economic Geography and in 'New Regionalism': A Sympathetic Critique." International Journal of Urban and Regional Research 30 (3): 690-704. https://doi.org/10.1111/j. 1468-2427.2006.00683.x.

Hadjimichalis, Costis. 2017. Crisis Spaces: Structures, Struggles and Solidarity in Southern Europe. London: Routledge.

Hadjimichalis, Costis, and Ray Hudson. 2007. "Rethinking Local and Regional Development. Implications for Radical Political Practice in Europe." European Urban and Regional Studies 14 (2): 99-113. https://doi. org/10.1177/0969776407076290.

Hadjimichalis, Costis, and Ray Hudson. 2014. "Contemporary Crisis Across Europe and the Crisis of Regional Development Theories." Regional Studies 48 (1): 208-18. https://doi.org/10.1080/00343404.2013.834044.

Harvey, David. 1982. The Limits to Capital. Oxford: Blackwell. 
Healey, Patsy. 1997. Collaborative Planning: Shaping Place in Fragmented Societies. Basingstoke: Macmillan.

Hudson, Ray. 2005. Economic Geographies. Circuits, Flows and Spaces. London: Sage. http://dx.doi.org/10.4135/9781446216743.

Hudson, Michael. 2010. "The Transition from Industrial Capitalism to a Financialized Bubble Economy.” Working Paper 627, Levy Economics Institute. http://ssrn.com/abstract=1695039.

Hudson, Ray. 2017. "Facing Forwards, Looking Backwards: Coming to Terms with Continuing Uneven Development in Europe." European Urban and Regional Studies 24 (2): 138-41. https://doi.org/10.1177/0969776416689230. Jessop, Bob. 2011. "Rethinking the Diversity and Variability of Capitalism: On Variegated Capitalism in the World Market." In Capitalist Diversity and Diversity Within Capitalism, edited by Christel Lane and Geoffrey T. Wood, 211-37. London: Routledge.

Lazzarato, Maurizio. 2012. The Making of the Indebted Man: An Essay on the Neoliberal Condition. Los Angeles: Semiotext(e).

Massey, Doreen. 1979. "In What Sense a Regional Problem?" Regional Studies 13 (2): 233-43. https://doi.org/10.1080/09595237900185191.

Massey, Doreen. 2006. "Space, Time and Political Responsibility in the Midst of Global Inequality.” Erdkunde-Archive for Scientific Geography 60 (2): 89-95. https://doi.org/10.3112/erdkunde.2006.02.01.

Myrdal, Gunnar. 1957. Economic Theory and Under-Developed Regions. London: Duckworth.

Sayer, Andrew. 2015. Why We Can't Afford the Rich. Bristol: Policy Press.

Smith, Adrian. 2013. "Europe and an Inter-Dependent World: Uneven GeoEconomic and Geo-Political Developments." European Urban and Regional Studies 20 (1): 3-13. https://doi.org/10.1177/0969776412463309.

Storper, Michael. 1997. The Regional World: Territorial Development in a Global Economy. New York: Guilford Press.

Thoidou, Elisavet, and Dimitris Foutakis. 2006. "Metropolitan Thessaloniki and Urban Competitiveness: Programming, Transformation and Implementation of a 'Vision' for the City." Geographies 12: 25-46 (in Greek). 
Open Access This chapter is licensed under the terms of the Creative Commons Attribution 4.0 International License (http://creativecommons. org/licenses/by/4.0/), which permits use, sharing, adaptation, distribution and reproduction in any medium or format, as long as you give appropriate credit to the original author(s) and the source, provide a link to the Creative Commons license and indicate if changes were made.

The images or other third party material in this chapter are included in the chapter's Creative Commons license, unless indicated otherwise in a credit line to the material. If material is not included in the chapter's Creative Commons license and your intended use is not permitted by statutory regulation or exceeds the permitted use, you will need to obtain permission directly from the copyright holder. 


\title{
4
}

\section{State Power, Spatial Inequality, and Geographical Expertise: Notes on Method}

\author{
Merje Kuus
}

\section{Introduction: Policy Expertise in Transnational Processes}

This chapter is about policy, state power, and research method. My practical questions are about the everyday creation of policy expertise. I ask: how is expert authority made in transnational policy settings? More specifically, how is the everyday creation of policy expertise changing today, as ever more state and non-state actors participate in policy-making at both national and international levels? Where are the centres and margins of expertise in a political space like the European Union and how do the fortunes of specific places rise and fall in these processes? What is the role of states and national institutions in this process and how are these institutions transformed in the process of transnational policy-making?

M. Kuus ( $\square)$

University of British Columbia, Vancouver, BC, Canada 
Intersecting with these practical questions about state power are methodological puzzles and dilemmas about how we ought to study transnational policy expertise and the role of states in it. What can we take as evidence of transnational dynamics in the context in which most information is produced by nationally affiliated experts and commentators? The chapter is indeed as much about research method as it is about policy, expertise, or state power in Europe.

The chapter will proceed in three steps. I will first make an argument about the transnationalisation of policy knowledge in Europe: the ways in which policy expertise, including state-governing expertise, is produced in ambiguous and ephemeral transnational networks. I will then highlight some of the ways in which that process of transnationalisation is fundamentally uneven and may indeed accentuate rather than reduce existing inequalities in the field of policy expertise in Europe. I will finally foreground some of the methodological challenges encountered in the study of transnational policy processes. My empirical examples come from the fields of diplomacy and diplomatic training, but my effort is to illuminate the dynamics of knowledge production in policymaking institutions more broadly. ${ }^{1}$

Diplomacy and other such knowledge-intensive fields are important to examine because experts in these fields craft the knowledge claims on which basis policies are made in the first place. Experts do not simply tell us how things work or ought to work. Experts also tell us what exists, what is significant, and what is possible. Policy-making is in part an administrative practice. It is also an intellectual and imaginative social practice.

My empirical analysis is based on ten years of work. It draws in part from about 160 one-to-one loosely structured interviews with foreign policy professionals, mostly diplomats. The interviews were conducted with over ninety such professionals between 2007 and 2017, in small sets of 10-15 interviews per year. They were carried out mostly but not exclusively in Brussels (cf. Kuus 2014, 2017a). My goal was not to find out what diplomats think about particular policy issues. Rather, I tried to elucidate the rules for the production of rules in diplomatic institutions. My enquiry is ultimately about knowledge and state power. 
Most of the direct quotes that I bring from that material come from a smaller and more recent sub-set of the material: about fifty interviews that focus specifically on the transnationalisation of regulatory power and the diplomatic profession today. These fifty interviews were conducted in Brussels and eight other nodes of diplomatic knowledge in the last three years. Most of them probe the transnationalisation of state-governing expertise: the transnational networks of ideas and influence through which state power is produced and transformed today.

\section{Transnationalisation of States}

In the facet that is easily visible in daily practice and academic research, diplomacy is about the inter-national negotiation of national interests. So is EU policy-making. The most important decisions in the EU are taken intergovernmentally and inter-nationally. Even in the supposedly supranational settings of the European Commission, national perspectives are clearly discernible and carefully guarded. "The most important skill in Brussels is nationality", a long-time observer remarks caustically about EU policy-making. Many if not most issues and debates in Brussels are habitually plotted onto a national matrix in which power is viewed in terms of the competition and collaboration among pre-given entities called nation-states (Kuus 2015).

Yet, the daily grind of diplomatic work is becoming increasingly trans-national rather than inter-national: it involves substantial transnational circulation and mutation of ideas and practices. When one looks at how diplomats actually do their work, and when one really tries to notice what one usually does not notice, the picture is not so inter-national. When one tries to see not only what diplomats do today but also what they are willy-nilly being trained and socialised to do in twenty years, a more transnational scene emerges.

As an example of the ambiguous feel of the shifts at hand, consider this culinary metaphor from a national diplomat in Europe. The greatest difficulty in European Union decision-making, he observes, is coordinating the underlying approaches to issues: the ways of looking at 
problems, the methods of addressing them administratively. You can develop procedures for communication, but the often unconscious lenses, deeply rooted in national cultures, are hard to alter. The difficulty is often underestimated, the interviewee observes. "There is a nice European sauce that someone has poured over the differences [he makes a gesture of pouring something over a dish carelessly and in copious quantities]", but this often only coats and masks rather than harmonises the differences.

At first glance, this diplomat stresses the inter-national character of diplomacy. The sauce is cast as a useless obstruction on an inter-state scene. But it is noted. There is something in addition to the inter-national shaping that dish. If we overemphasise the sauce, we lose something. But if we ignore the sauce, we also miss something. There is a tendency to focus on the so-called real stuff_-states_-underneath the sauce. The tendency is there in part because the causal powers of the sauce cannot be neatly identified. It is easy to identify a state as an actor. In diplomacy and in EU policy-making, these are literally states who speak in negotiations settings: France says this or Germany says that. Identifying an agent in a diffuse transnational web of activity is far more difficult.

In diplomacy, foreign ministries still do most of the professional training. At first glance, the various initiatives, which I will not review here (see Kuus 2017a), seem to illustrate mostly the inter-national connections of state institutions. In addition to the business as usual, diplomatic training also extends beyond state structures and operates through transnational competition for resources both material and symbolic. Most visibly, many courses operate at the margins or outside of formal ministerial structures, via universities, research institutes, foundations, or consulting companies.

State power also operates through long-term structural tendencies rather than specific formal policies. For example, a number of EU member states, more so the richer than the poorer ones, offer scholarships to their nationals to study at the College of Europe, a specialist post-graduate institution that has long served as a training ground of EU civil servants. The states do this in the hope that these graduates subsequently succeed in EU institutions and put their national perspectives in play in EU structures. These initiatives do not amount to 
diplomatic training in formal terms, but they illustrate the recognition among nation-states that effective long-term influence requires actions much beyond the national capital (Kuus 2018).

When one tries to understand what places matter in the European field of diplomatic expertise, one needs to consider not only states or institutions as such. One also has to consider the various institutions' and training initiatives' alumni networks in Brussels and around the world. In such networks, state power is modulated through intangible symbolic resources, such as reputation. For example, how do we assess the importance of an alumni network around the London School of Economics and Political Science, the Johns Hopkins University Centre in Bologna, the European University Institute in Florence, or Tufts University in Cambridge, Massachusetts? If we look at diplomatic training as a broader social field of connections and struggles, we begin to discern patterns that are not neatly intergovernmental or inter-national, but operate along transnational axes of differentiation.

Many of the diplomats I interview in Europe note the distinctiveness of EU-level diplomacy: both the negotiations among the member states and the external diplomacy of the EU as a whole. "The Brussels skill... [a diplomat says, while appearing to be sifting sand through his fingers] ... you cannot apply what you learned in your ministry". Influence in the EU, The Economist (2013) magazine remarks along similar lines, is like the Brussels drizzle: ubiquitous but hard to pinpoint. It is observable not in its application at any one point in time but in its cumulative effects over time. It may be fashionable in some capitals to glorify the 'big boys' bilateral diplomacy over what The Economist calls the "delicate dance" (The Economist 2014) in Brussels, but the diplomats sent to do the dance are often the most skilled these same capitals can muster. When Britain's Permanent Representative resigned unexpectedly in early 2017, many noted that losing someone so well-versed in the "silken culture" of Brussels ought to worry London (D’Ancona 2017).

Even in large foreign services, skilled diplomats recognise that Brussels ups the game for them. In a national diplomacy, a diplomat observes, you advance the national interest, which, for practical purposes, is expressed by the government in office. In EU diplomacy, you further the European interest. But what is that? It has to be distilled, 
felt: it is constantly challenged and revised. Several interviewees, in different diplomatic services, instinctively reach for tactile gestures to characterise the process. It might be a gesture of feeling a fabric between their fingers to test its quality. Or the gesture of sifting sand through their fingers to feel its grain. Or feeling something amorphous and hard to grasp. As my work on diplomatic training has progressed, remarks about what I call the cloth gesture increasingly appear in my notes as I learn to notice such gestures.

The gestures convey something intangible and qualitative: something that can be discerned, but not measured. Once I dare to consider the references to silk and drizzle as evidence of slow and diffuse shifts in atmosphere and relations, different long-term futures come into relief. Once I ask what kinds of spaces diplomats are being prepared for, not in the next year but in the next twenty years, I realise that inter-national spaces these are not-at least not in the minds of the more light-footed among the dancers.

As an example, consider the following vignette. When Brussels began to ponder the impending retirement of Pierre Sellal, France's Permanent Representative, and the acknowledged Sun King of the Brussels diplomatic scene, even the admirers of his "light-footed charm" noted that Sellal may be the last of his kind. His "parlour games" of big player alliances, Salmon Mousseline, and bottles of Grand Cru worked well so far, but the new representative may need to work with a broader range of actors. In the "somewhat regretful" characterisation of the parlour game from a diplomat from an Eastern European who said: "Pierre never had to approach me for support. He had always his majority arranged and ... elegantly presented at the meeting" (De la Baume and Vinocur 2016). Some of those in the parlours take note of that regretful tinge and wonder whether France can afford to be so confident about its influence. "He's sometimes too French", a French diplomat says of Sellal: "He is the Frenchman who knows the Brussels machine best. The question now is, the diplomat continues, whether this version of Brussels corresponds to the reality of today" (ibid.). If the French, whose diplomacy is highly regarded in Brussels, may need to reconsider their approach, is the big power game really an option for any member state? 
Traditional categorisations of interest and identity have modest utility in these circumstances. The neat terminology of levels and stages of decision-making - national, European, Brussels, and so on-is of limited value as the actual daily horse-trading does not follow the binaries of national vs. European or intergovernmental vs. supranational. The question is not who has the upper hand in the relations between Brussels and the member states. The question is how to analyse regulatory power in Europe without that binary of Brussels and the member states and without the national matrix that imagines power in state-based terms and thereby unimagines transnational connections (Kuus 2017b).

\section{Uneven Europe}

Yet, this is not some kind of mythical harmonised space of European expertise. It is a space of knowledge articulated through existing power relations. I will thus briefly delve into some of the uneven and unequal patterns in that space. One of such intangible resources concerns societal wealth-both government spending and the broader societal wealth discernible through the sophistication of the media, education, and social scene more broadly.

Diplomatic protocol codifies the nominal parity of states and encourages the polite pretence of it. Specialist literature customarily presents the profession in terms of national perspectives. It implies that one can jump from power centres to power margins with examples; that the training programmes, university research, or journalistic reporting generated in different countries are usually on par. The little secret is that diplomatic expertise is expensive. Its production requires long-term strategic spending much beyond the foreign ministry. Put bluntly, symbolic capital costs money.

This comes to the fore in Brussels. In that node of global power, work is more "sociological" than traditional bilateral diplomatic practice, an interviewee explains. It requires a certain intangible feel for the game. That feel does not come cheaply. The richer countries can start with a better prepared pool of applicants because they have better universities and a more sophisticated media landscape. These more affluent systems 
can weigh and debate the importance of thematic, regional, or other forms of expertise. They can appoint advisors to do some of this work. They can rotate diplomats widely and benefit from the diverse networks forged in the process. The less well-to-do systems focus on the skills that they can train quickly and cheaply in-house.

For some of the poorer EU member states, seconding junior diplomats to the EU diplomatic service as desk officers at geographical units is their best chance to give these professionals some exposure to distant places. Without continuous exposure to regional expertise in the home capital as well, the long-term effect is uncertain. The impact of such long-term exposure is difficult to measure. Qualitatively, it plays. One can see, a council official speaks of the negotiations there, that big rich countries' diplomats' knowledge of, say, Africa, is qualitatively better from what those from small Central European countries can muster. The small countries are understandably sensitive to their immediate neighbourhood. In EU settings though, the game is often bigger and Eurocentric knowledge is insufficient.

In theory, the smaller and poorer countries can use digital technologies to access information and networks without training diplomats to be present physically. In practice, there is, to quote two different interviewees, a "huge", even "growing" gap between possibility and reality. In addition to the visible power, visible from things like diplomats being around the table, there is, what yet another interviewee calls the invisible power of personal networks. That invisible power cannot be acquired via an e-mail list: it requires long-term inter-personal relationships of professional trust. In Brussels, what plays is not only the instructions and negotiation skills in Brussels, but, more broadly, the pre-Brussels training and socialisation (Kuus 2018).

The differences in wealth should not be overplayed and the unevenness cannot be captured by GDP figures. Generalisations must be done tentatively. "It seems to me", I solicit feedback from a senior diplomat, "that if someone comes from a relatively rich diplomatic service, where there is some space for a certain-relaxed-exploration of complex social issues, that person is better prepared for Brussels than someone who comes from a shoestring ministry, equipped with unrealistic instructions and little else". "The important word there is 'relaxed', 
not 'rich", the person responds. Stable ministries with long traditions, including the traditions of mentoring, fare better, but it is the tradition rather than the budget that plays. There are examples, the interviewee continues, of relatively poor countries with strong diplomatic services owing to that benefit of tradition. Nobody cites a rich country without a strong tradition. Wealth brings you the tradition in any event (see also Kuus 2018).

The picture that is beginning to emerge is a networked transnational market for diplomatic expertise. Nation-states, aided by nationally based foundations and universities, buy and sell their expertise in Europe and beyond: the poorer ones tend to buy and the richer ones tend to sell. The boundaries between state and non-state actors are growing more ambiguous and permeable. Formal institutional structures matter alongside intangible symbolic resources like connections and reputation. Transnationalisation does not undo national power or the pecking orders of states. It complicates these orders and it problematises the whole idea of a nationally based pecking order.

\section{Method: Studying Everyday Practice}

The preceding material raises methodological questions about what we take as evidence, and what conclusions we draw on the basis of that evidence-or, more broadly, how we know what we know. The rest of the chapter focuses on that question. It thereby probes some of the key methodological difficulties with analysing opaque transnational policy processes.

Power in Brussels is fundamentally about contextualisation: about the capacity to advance long-term national interests in the context of that specific place. Much of that knowledge is contextual, place-based, and atmospheric. It is in the air like a drizzle, like water vapour, like fragrance. And it is embodied, tightly linked to the personal knowledge, skill, reputation, and networks of individual diplomats. Looking for clear or hard evidence cannot uncover it. Methodologically, bringing out the subtle transnationalisation of European diplomacy (and policy 
expertise) requires that we work with the "regretful tinge" and the barely discernible criticism of parlour games from the French themselves. But how to articulate such atmospheric issues in a rigorous scholarly manner? To what degree are references to silk and dance and mousseline, or the cloth gestures, serious evidence rather than anecdotes, interpretations, or otherwise insubstantial speculation?

Analysing a transnational field requires attention to patterns that are at once diffuse and specific. This is difficult given that data sources are national and the interviewees tell stories that are national both at the level of overt talking points and at the level of subterranean angles and habits. Telling a different story requires a sustained effort to start somewhere else than an intergovernmental network of national foreign ministries. In order to trace the transformation of state power in diplomatic practice, we need to move beyond common-sense labels like nation-states or Europe and closely trace the blurring of these categories in empirical terms. This requires that we move beyond institutional dynamics and take the mundane and informal building blocks of daily life as our object of analysis.

Methodologically, this requires that we take the ephemeral, metaphorical, and opaque remarks about the transformations of diplomatic work seriously. References to "the Brussels skill", "the delicate dance", "the drizzle" of influence, or the "silken" character of the EU scene indicate not a different hierarchy of states but a certain deliquescent and diaphanous transformation of the diplomatic field. The effect of "the Brussels drizzle" can be discerned not in any one moment but in the social field over time. Methodologically, the task is to give an account of the contingency of diplomatic practice without squashing it into a pre-made typology, model, or storyline. The task is equally to notice practices that exceed and evade formal institutional structures and governmental positions. In the study of transnational spatial practice, empirical data are necessarily more fragmented and amorphous than official papers would lead one to believe. Such a study requires not only a matter of different data, such as interviews and direct in situ observations. It also requires that we notice different things in the data and not purify the messiness of daily life in advance of the analysis (Barry 2013, 27). 
We must keep in mind that 'careful' and 'comprehensive' are not the same thing: in the study of diffuse phenomena, the two goals may indeed contradict each other (Kelty 2008, 20). Focusing on place as a central component of the context helps one to discern the silken delicacy of situated and place-specific relationships in ways that the content analysis of policy documents disallows. We cannot overcome the constrictions of structuralist models (Adler-Nissen 2016,2) by the methods that produced these models.

It is one thing to note such details as anecdotes; it is another to craft a rigorous scholarly study from them. Transnational connections are emergent and evaporative: nationally produced documents do not tout them and national civil servants do not highlight them. Discerning these patterns requires concerted analytical effort.

To study practice is to explore:

the ways of frequenting or dwelling in place $[\ldots]$ and on the many ways of establishing a kind of reliability within the situation imposed on an individual [...] Like the skill of a driver in Rome or Naples, there is a skill that has its connoisseurs and its aesthetics exercised in any labyrinth of powers, a skill ceaselessly recreating opacities and ambiguities-spaces of darkness and trickery-in the universe of technocratic transparency. (De Certeau 1984, 18, xxii)

Efforts to codify all procedures, by giving maximum location and identification data on the interviews, for example, can obscure rather than reveal these opacities and ambiguities. Michel de Certeau (1984, 21), a French cultural theorist, writes:

Of the practices themselves, science will retain only moveable elements (tools and products to be put in display cases) or descriptive schemas (quantifiable behaviours, stereotypes of the staging of social intercourse, ritual structures), leaving aside the aspects of society that cannot be so uprooted and transferred to another space: ways of using things or words according to circumstances. [...] Indeed, like Schreber's God, who 'communicates only with cadavers' our knowledge seems to consider and tolerate in a social body only inert objects. 
The kind of study de Certeau advocates requires us to see different patterns in the ephemeral intersubjective situation of iteration. The task is, in part, to wilfully focus on what does not seem to exist. This is tricky. Wilful interpretation can easily become wishful thinking. Labelling something transnational rather than intergovernmental in origin does not make it that.

The references to dance and silk and mousseline are all direct quotes from journalistic reporting. I just make more of these fleeting references than I usually dare to do. I take them seriously as evidence of a series of transformations in state power and state-governing expertise in Europe. I accentuate the individual, the contextual, the embodied, the experiential, and the fleeting in both primary and secondary research. I make much of the small comments and halfthoughts that destabilise the business as usual but tend to be brushed aside in traditional state-centred accounts. A big part of such data is publicly available, in gossip, newspaper commentary, and daily life. I do not necessarily need to do a traditional ethnography in Brussels. There are plenty of observant people in Brussels and they write plenty. What I need, and often find difficult, is a different kind of awareness and risk-taking ahead of the collection of data. We must be keenly aware of the distinction between categories of practice and categories of analysis. Ask a practitioner of diplomacy about her profession and she will tell you a story of national interests. But this does not mean that your analysis of diplomatic practice has to be statebased as well.

Analysing a transnational field requires attention to patterns that are at once diffuse and specific. This is difficult: data sources are national and the interviewees tell stories that are national both at the level of overt talking points and at the level of subterranean angles and habits. Telling a different story requires a sustained effort to start somewhere else than an intergovernmental network of national foreign ministries. In order to trace the transformation of state power in diplomatic practice, we need to move beyond common-sense labels like nation-states or Europe and closely trace the blurring of these categories in empirical terms. This requires that we move beyond institutional dynamics 
and take the mundane and informal building blocks of daily life as our object of analysis.

This underscores the importance of methodological and conceptual pluralism in the study of international practice and social power. Diplomacy is a fine empirical lens through which to practise such pluralism. To effectively represent the interest of their states, diplomats must be open to encounters with difference. This, in turn, requires that they wear their pre-existing assumptions about places lightly. The single most frequent qualifier in my interview material concerns the contingency of interests, alliances, priorities, policies, outcomes. The more experienced the diplomat, the more likely they are to cite contingency and context-specificity. True, such performative production of contingency is partly a habit of negotiation: to cite contingency is to guard your cards. The category is not entirely devoid of substance, though; alert openness to context and contingency is central to diplomatic skill. "The first and best advice I can give a young man entering this career", the Earl of Malmesbury wrote in 1813, "is to listen, not to talk —at least, not more than is necessary to induce others to talk" (Roberts 2009, 619, emphasis in original).

\section{Conclusion: For Open-Ended Questions}

The chapter made three points. The first concerned the transnationalisation of policy expertise, the second concerned the uneven character of the process, and the third concerned the methodological difficulties of trying to create an analytically rigorous and empirically nuanced account of these processes. My overall effort is to nudge us toward a more openended analytical and methodological framework, less beholden to the usual formulations around the levels and scales of analysis.

A central difficulty with comprehending spatial planning in today's Europe stems from the methodological nationalism of our analytical toolbox. The power of European institutions and the patterns generated by EU-level funding, knowledge, and influence tend to be fitted into an international framework. As a result, EU power is treated as a 
veneer on an otherwise national picture. This obscures the parallel process: the ways in which national labels serve as a veneer on EU regulations. The analytical task is not to figure out where the nation-state ends and the EU begins, but to acknowledge that Europe and its member states are not distinct politically or analytically. European Union regulations present themselves to the observer in national form, but they are transnational rather than national in content and origin (Kuus 2017b). To highlight this is not to imply some mythical happy family of united Europe. The continent has been a deeply unequal space economically and politically since the inception of the modern idea of Europe in the eighteenth century. An explicitly transnational rather than national starting point gives us a more flexible framework in which to investigate the ever-shifting patterns of economic, political, and symbolic peripherality. The methodological argument reminds us about the inherent ambiguity and indeterminacy of these processes. The methodological dilemmas about what exists, how we know this, and how we come to know this, cannot be resolved: they can only be pondered.

Faced with such interminable ambiguity, I end with a quote from one of my interlocutors in Brussels. Whatever else diplomats might do, that experienced practitioner observes, they "must be open, to see new patterns". An intellectual and experiential openness is good advice for those interested in unpacking the emergent transnational patterns of expert knowledge and state power.

Acknowledgements Research for this chapter was supported by the Social Sciences and Humanities Research Council of Canada. I thank Thilo Lang and the audience in Leipzig for engaging with my argument.

\section{Note}

1. I do not review the voluminous literature on state power, transnational fields, EU policy-making, diplomacy, or ethnographic methods. The citations are available in the studies referenced herein. 


\section{References}

Adler-Nissen, Rebecca. 2016. "Towards a Practice Turn in EU Studies: The Everyday of European Integration.” JCMS: Journal of Common Market Studies 54 (1): 87-103. https://doi.org/10.1111/jcms.12329.

Barry, Andrew. 2013. Material Politics: Disputes Along the Pipeline. Chichester: Wiley-Blackwell.

D’Ancona, Matthew. 2017. "Sir Ivan Rogers' Sudden Departure Is a Hit to Theresa May's Brexit Plans." The Guardian, January 3. https://www.theguardian.com/commentisfree/2017/jan/03/brexit-ivan-rogers.

De Certeau, Michel. 1984. The Practice of Everyday Life. Berkeley: University of California Press.

De la Baume, Maia, and Nicholas Vinocur. 2016. "The Last Sun King of French Diplomacy." Politico Europe, November 25. https://www.politico.eu/ article/the-last-sun-king-french-diplomacy-pierre-sellal/.

Kelty, Christopher. 2008. Two Bits: The Cultural Significance of Free Software. Durham: Duke University Press.

Kuus, Merje. 2014. Geopolitics and Expertise: Knowledge and Authority in European Diplomacy. Chichester: Wiley-Blackwell.

Kuus, Merje. 2015. "Transnational Diplomacy in Europe: What Is Transcended and How?" In Diplomatic Cultures and International Politics: Translations, Spaces and Alternatives, edited by Jason Dittmer and Fiona McConnell, 41-58. London: Routledge.

Kuus, Merje. 2017a. "Transnational Institutional Fields: Positionality and Generalization in the Study of Diplomacy." Political Geography (early view). https://doi.org/10.1016/j.polgeo.2017.02.008.

Kuus, Merje. 2017b. "Locating Europe's Power, or the Difference Between Passports and Passporting." Discussion Forum (with Fiona McConnell, Alex Jeffrey, Adrian Smith, Nick Vaughan-Williams, and Heaven Crawley) "Interventions on Europe's Political Futures." Political Geography 60: 261-71. https://doi.org/10.1016/j.polgeo.2017.02.003.

Kuus, Merje. 2018. "Political Economies of Transnational Fields: Harmonization and Differentiation in European Diplomacy." Territory, Politics, Governance 6 (2): 222-39. https://doi.org/10.1080/21622671.201 6.1266960.

Roberts, Ivor. 2009. Satow's Diplomatic Practice. 6th ed. New York: Oxford University Press. 
The Economist. 2013. "Anatomy of a Failure." The Economist, March 9. https:// www.economist.com/news/europe/21573138-britains-defeat-over-bankers-bonuses-sign-declining-influence-anatomy-failure.

The Economist. 2014. "Dance of the Powers." The Economist, September 6. https://www.economist.com/news/europe/21615618-debate-over-eus-topjobs-has-little-do-europes-many-challenges-dance-powers.

Open Access This chapter is licensed under the terms of the Creative Commons Attribution 4.0 International License (http://creativecommons. org/licenses/by/4.0/), which permits use, sharing, adaptation, distribution and reproduction in any medium or format, as long as you give appropriate credit to the original author(s) and the source, provide a link to the Creative Commons license and indicate if changes were made.

The images or other third party material in this chapter are included in the chapter's Creative Commons license, unless indicated otherwise in a credit line to the material. If material is not included in the chapter's Creative Commons license and your intended use is not permitted by statutory regulation or exceeds the permitted use, you will need to obtain permission directly from the copyright holder.

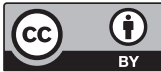




\section{Part II}

\section{Regional and Cohesion Policies \\ (Re-)producing Socio-Spatial Disparities}




\title{
5
}

\section{Re-conceptualising Territorial Cohesion Through the Prism of Spatial Justice: Critical Perspectives on Academic and Policy Discourses}

\author{
Rhys Jones, Sami Moisio, Mikko Weckroth, \\ Michael Woods, Juho Luukkonen, Frank Meyer \\ and Judith Miggelbrink
}

\section{Introduction}

One the key principles of the European Union has been its emphasis on the need to promote a Social Model, one which seeks "to give to the people of Europe the unique blend of economic well-being, social cohesiveness and high overall quality of life" (European Commission 1994, 1). But, of course, one of the most significant aspects of this Social Model is the fact that it has also been spatialised in fundamental ways. From the

R. Jones $(\square) \cdot$ M. Woods

Aberystwyth University, Aberystwyth, UK

S. Moisio · M. Weckroth · J. Luukkonen

University of Helsinki, Helsinki, Finland

F. Meyer

Leibniz Institute for Regional Geography, Leipzig, Germany

J. Miggelbrink

Technische Universität Dresden, Dresden, Germany

(C) The Author(s) 2019

T. Lang and F. Görmar (eds.), Regional and Local Development

in Times of Polarisation, New Geographies of Europe,

https://doi.org/10.1007/978-981-13-1190-1_5 
1980s, there has been a growing academic and policy focus on the specific ways that "Europe was divided into a geographical and development core and periphery" (e.g. Sarmiento-Mirwaldt 2015, 433). It was also acknowledged that a concerted set of interventions was needed in order to reduce these territorial inequalities. The European Commission (European Commission 2004, 27), by the beginning of the new century, stated that it wanted "to help achieve a more balanced development by reducing existing disparities, preventing territorial imbalances and making both sectoral policies which have a spatial impact and regional policy more coherent". Convergence policies of different kinds have used this explicitly spatialised way of thinking as a way of targeting under-performing regions, while at the same time seeking to improve the overall competitiveness of all European regions. And yet, despite high levels of investment and institutional support, such convergence policies have experienced limited success. For example, some EU countries such as Hungary and Poland have long been receiving a large share of Cohesion and European Regional Development Fund funding and yet they have introduced certain illiberal social and political reforms that are in stark contrast with oftenmentioned "fundamental values" of the European Union. At the same time, EU-orchestrated austerity policies imposed on these countries have only served to underline the entrenched and worsening character of regional and socio-economic inequalities. For instance, empirical data demonstrate that 16 out of 26 countries in the European Union (with available data) have registered increases in regional GDP disparities for NUTS3 regions between 2007 and 2011 (including France, Greece, Ireland, Italy, the Netherlands, Poland, Spain and the UK). It is against this backdrop that many academics and policy-makers are beginning to question some of the fundamental principles that underpin the European Social and Spatial Model. It is against this conceptual and empirical backdrop, too, that we write this chapter.

We have two main aims in this chapter. Our first aim is to review academic and policy engagements with the ideas of territorial and regional inequalities within Europe, drawing particular attention to the emphasis that has been placed on understanding such inequalities in relation to ideas of territorial cohesion (TAEU 2007). We discuss some of the conceptual limitations of the idea of territorial cohesion. Our 
second aim is to deliberate the conceptual and more policy-related benefits that potentially arise from the notion of spatial justice.

Spatial justice is a concept that has gained some conceptual traction since the early 1970s (e.g. Harvey 1973; Lefebvre 1970) and there is some evidence to show that it is now being viewed by European policy-makers as a viable alternative or even substance to territorial cohesion policies. We outline some of the potential benefits that might accrue from framing European interventions that seek to reduce territorial and regional inequalities through reference to ideas of spatial justice.

While the idea of spatial justice does not represent a policy panacea, we maintain that it has the potential to: (1) allow academics, policy-makers and the public alike to coalesce around a positive and aspirational end goal, centred on the idea of justice; (2) enable a more progressive discourse on regional development to emerge, which focuses on the capabilities of regions and territories to develop and succeed (rather than being a discourse that views regions and territories as ones that exist merely to receive financial and institutional support from the outside); and (3) allow plural understandings of development, justice, well-being and the 'good life' to emerge-ones that are attuned to the regions and territories from which they emanate.

\section{The Rise and Fall of the European Union's Territorial Cohesion: From Competitive to Inclusive Europe?}

The European social model and conceptions of economic competitiveness within Europe have increasingly been viewed in spatial terms since the late 1990s. From this period onwards, the European Commission began to use the concept of territorial cohesion as a policy tool to tackle regional differentiation and spatial disparities (European Commission 2001). Implementing territorial cohesion as part of the European Social Model has aimed at extending the principle of social protection into more spatial realms (Davoudi 2007, 81). Territorial cohesion, thus, seeks to tackle place- and region-specific problems that have the potential to undermine attempts to establish the European Union as 
a strong political and economic territory. The emergence of European spatial planning agendas and practices, for instance, has been explicitly concerned with reducing socio-economic inequalities between different European states and regions (Abrams 2014; Faludi 2010). Structural funds represent another important tool that the European Union has used as a way of addressing spatial inequalities, with varying levels of success (Allen 2005). These kinds of policies have involved an explicit articulation of the European Union's territorial cohesion agenda. The idea of territorial cohesion was re-emphasised in 2005 after the enlargement of the European Union. Since then, addressing territorial inequalities within the framework of the European Union has grown in importance due to the 2008 economic crisis and the notable wave of immigration from outside the Union, which peaked in 2016.

The idea of territorial cohesion has, therefore, grown in significance since the turn of the century, in both policy and more academic contexts. Figure 1 illustrates the cumulative number of hits for the term 'territorial cohesion' on the basis of a Google Scholar search. The figure reveals that the number of academic works using the term territorial cohesion has grown at the same time as territorial cohesion has emerged

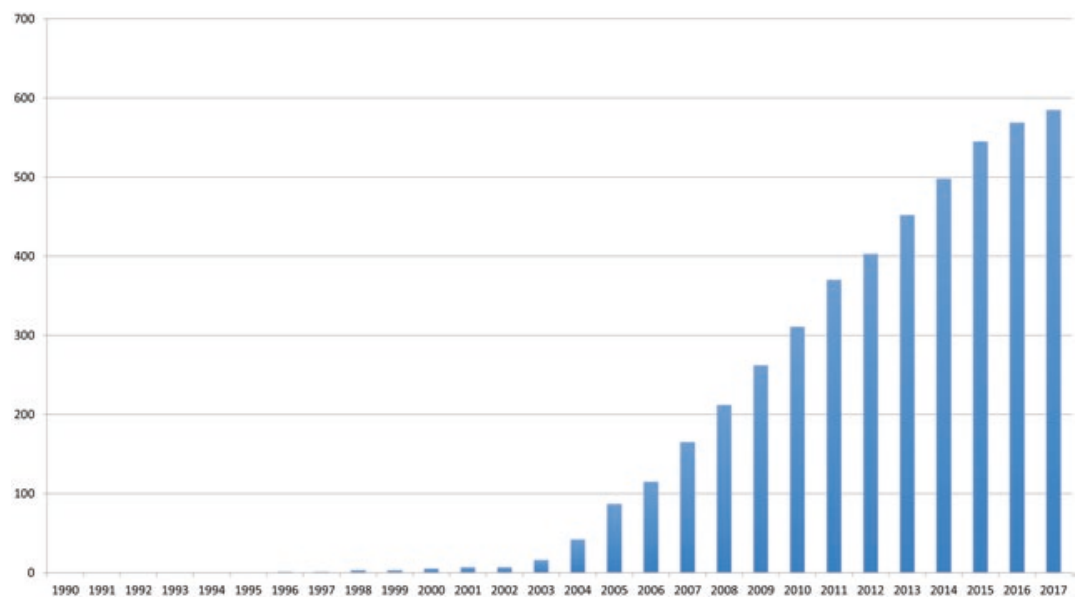

Fig. 1 The cumulative number of hits for the term 'territorial cohesion' on the basis of a Google Scholar search 
as a policy priority within the European Union. Until the publication of the Amsterdam Treaty, 'territorial cohesion' gives around 150 search engine hits, while the search for the period from 1997 to 2002-the year following the publication of the Second Report on Economic and Social Cohesion (European Commission 2001), which devoted a separate section to territorial cohesion-gives around 250 hits. The search for the next five-year period (2003-2008) indicates a booming era for research on territorial cohesion within academia (over 2100 hits). This is not a big surprise, given that this period witnessed key milestones in the European Union's spatial policies, most notably the publication of the Third Report on Economic and Social Cohesion (European Commission 2004), the publication of the preliminary results of the politically influential ESPON programme (ESPON 2004), the publication of the proposal for the EU constitution, and the launching of the Territorial Agenda of the EU, whose final version was published in 2007 (TAEU 2007). In all these documents, territorial cohesion is brought to the fore as a significant political agenda both for the EU and for the individual member states (cf. Davoudi 2005). Not surprisingly, such developments also acted as the source for considerable academic debate. Since 2009, the number of academic publications referring to territorial cohesion has grown even more remarkably. The almost 12,000 hits with Google Scholar indicate that the concept has not only been consolidated in the policy vocabulary of the European Union (in the Directorate General on Regional Policy in particular), but also that it is no longer addressed solely within a small cadre of European planners and planning scholars, or EU bureaucrats. Instead, it has been grasped across disciplinary boundaries by a wide range of scholars interested in issues of spatial policies and development within and beyond the EU.

And yet, a purely statistical account of the growth of the significance of territorial cohesion as an approach to governance and as an academic concept does not say much about the meaning that is ascribed to the term. In broad terms, we maintain that territorial cohesion policies have enabled the territory of the European Union to be treated as a singular geopolitical object that can be measured, mapped, analysed and acted upon (Luukkonen and Moisio 2016). Territorial cohesion, viewed 
in these broad terms, is a political technology of territory that seeks to engender territorial solidarity and identification at the scale of the European Union, and in so doing challenges nation-state centred forms of identification. And yet, when one digs deeper, it becomes apparent that the idea and practice of territorial cohesion in the European Union have been characterised by multiple goals and even slightly contradictory objectives. It is not surprising, therefore, that territorial cohesion has been named as a highly ambiguous and contested term with many different layers of meaning (see, for instance, Mirwaldt et al. 2008; Servillo 2010; Atkinson and Zimmermann 2016; Schön 2005; Evers 2008). Significantly, from a more geographical perspective, it has been suggested that territorial cohesion might mean different things to different member states and actors, with the concept being appropriated to fulfil various policy demands in different places (Faludi 2015). In this sense, territorial cohesion has remained an elusive and complex concept, open to many different and varied interpretations. In essence, it is a flexible and normative European policy goal that can be manipulated in order to promote specific priorities in different national/regional contexts.

Adopting a genealogical or historical approach shows a strong connection between territorial cohesion and two pre-existing and contrasting conceptual frameworks. At one level, the discourse and practice of territorial cohesion have their roots in the decades-old French regional political idea of aménagement $d u$ territoire, a sort of spatial planning or regional policy that is directed towards maintaining territorial (national) unity by decentralising powers and mobilising regional and local actors around national territorial policies (e.g. Davoudi 2005; Faludi 2004). At the same time, there are links between territorial cohesion and the German tradition of regional policies called a comprehensive integrated approach. Compared to the French tradition, which is sometimes seen as a regional economic approach to spatial planning, the German tradition conceptualises space and spatial policies somewhat differently. Faludi (2004) has noted that from the French perspective, territorial cohesion is seen as ensuring balanced economic development and the establishment of solidarity between regions, whereas the German tradition directs towards the broader perspective of sustainable development. 
Focusing on these genealogies demonstrates that the idea of territorial cohesion-almost from the very outset—has been characterised by different emphases and, potentially, inconsistencies and contradictions. These tensions become even more apparent when one seeks to chart the different ways in which territorial cohesion has been discussed and applied within different policies since the beginning of the new century. We identify three different approaches to territorial cohesion in these more recent academic and policy engagements with the term.

The first approach examines territorial cohesion from the perspective of shifts in governance. In these studies, territorial cohesion is understood as something that provides new opportunities or frameworks for governing the European Union as well as national spaces, with structural funds being particularly significant. The governance perspective on territorial cohesion and development highlights the existence of a "fourth tier" of governance within the European Union (Holder and Layard 2011,2) which potentially "unbundles" state territoriality. In this perspective, the idea and the concept of multilevel governance are seen as a way of providing new possibilities for cross-sectoral and cross-border cooperation between different forms and levels of governance.

The second approach involves those studies that conceive of territorial cohesion as an explicit policy objective. Studies in this category examine the tensions between the policy objectives of, on the one hand, promoting spatially balanced economic development and, on the other, ensuring the competitiveness of regions and territories within Europe. In some of these contributions, territorial cohesion is seen as a way of combining these two objectives. Schön (2005), for instance, argues that pursuing territorial cohesion contributes to the redistribution of resources and the promotion of economic competitiveness by putting into practice integrated and holistic spatial development approaches. According to this politically popular reasoning, territorial cohesion policy has the potential to both reduce disparities and strengthen competitiveness by enabling regions to exploit their endogenous potentials (see Faludi and Waterhout 2005; Evers 2008).

The third approach to territorial cohesion in the scientific literature focuses more explicitly on those spatial frameworks or configurations 
that have the potential to reduce inequalities. In some studies, territorial cohesion is considered to give new stimulus to the European Spatial Development Planning agenda of promoting a polycentric spatial pattern for Europe, which would ultimately lead to balanced and sustainable development (Faludi 2005). Besides polycentricity, territorial cohesion is also connected-at least in implicit ways- to the idea of place-based development. Deriving from the Barca Report (2009), place-based development refers to the idea that public policies ought to be context-sensitive in a way that better takes into account the specific needs, characteristics, and potentials of places and regions. This is a theme that we will return to in the following section.

There is obvious overlap between these different approaches to territorial cohesion. Moreover, these approaches highlight the elusive nature of territorial cohesion within the academic and policy literatures. In both EU policy documents and academic debates, it is not always clear whether the concept refers to a policy objective that is pursued through a particular policy means or whether territorial cohesion is the policy tool or technology itself that is used to achieve certain policy goals. What is common in each of these approaches, however, is the emphasis that is placed on economic measures of territorial inequality and/or cohesion. Territorial cohesion, in this way, is primarily understood as a difference in economic production (in terms of GDP) between regions within Europe. Despite some limited references that are made to social forms of solidarity, the justifications that are used in order to promote territorial cohesion are almost invariably made on the basis of economic forms of accounting. Variance in regional GDP is viewed as being problematic, in this regard, because the European Union cannot afford the economic burden of 'lagging regions' (e.g. Hübner 2005). This emphasis on the economic dimensions of territorial inequality over and above social ones also highlights the agenda to label the allocation of structural funds as an act of investing rather than being a redistribution of public money. The concept of territorial cohesion and related spatially focused funding instruments of the European Union have been struggling with their public image and there has been a persistent political strategy within EU rhetoric to label these "spatial" funding instruments as investments rather than a redistribution of resources. 
Perhaps as a result of the elusive nature of the term, some have begun to question the usefulness of territorial cohesion as a policy concept and policy goal. As claimed by Hadjimichalis (in this volume) "territorial cohesion was high in the agenda but after 2008 and particularly after the crisis in 2010, it has been totally lost from any EU document”. While Hadjimichalis may be overstating the situation somewhat, it is evident that more recent understandings of territorial cohesion within EU documentation have become more limited, 'hollow' and multifaceted than ever. For example, the recent Cohesion Report from 2017 (European Commission 2017) is structured in chapters on economic, social and territorial cohesion. Territorial cohesion is now treated as an issue that is somehow separate and distinct from economic and social ones, with territorial cohesion being viewed in relation to different environmental challenges (e.g. climate change and pollution) affecting EU regions and with regard to various territorial cooperation schemes (e.g. cross-border connections). While these themes are obviously important for the future of the European Union at large, the nature of their connection to an economically and socially equal and just Europe is far from being clear.

We maintain that the above comments illustrate an increasing uncertainty in relation to the meaning of territorial cohesion and, arguably, a growing doubt-among policy-makers and academics alike-about its descriptive, analytical and normative value. From our perspective, beyond the general level of uncertainty that exists about its actual meaning, some of the more problematic aspects of the term territorial cohesion are as follows. First, there is potential for a discourse of territorial cohesion-especially when it is allied with talk of territorial inequalities-to reinforce a perception that certain 'under-performing' regions and states are somehow problematic or lacking, whether in relation to economic, social or environmental measures (and, of course, these are measures that are defined by those regions and states that are successful). In focusing on such issues, there is a danger that a status of inadequacy or even victimhood is ascribed to these regions. Second, and following on from the previous point, the traditional focus on territorial cohesion tends to promote an academic and policy discourse in which these 'problematic' or 'lagging' regions must receive external aid 
in order to succeed. Again, such a discourse tends to emasculate certain regions and states. Third, the discourse of territorial cohesion-in focusing on particular economic, social and environmental measures of success or failure-tends to define understandings of development, justice, well-being and the 'good life' in narrow ways, with little scope for alternative measures of success or progress to emerge. Lagging regions, in this way, are forever doomed to try to 'catch up' with their more successful counterparts, playing a game whose rules have been defined by the 'winners'.

There is a dire need, we argue, to ask whether spatial protection (Davoudi 2007) that is associated with the European Social Model can be imagined in alternative ways. It is in this context that we believe that a consideration of questions of spatial justice can offer some useful insights. Spatial justice, as we proceed to demonstrate below, allows: (1) various stakeholders to develop a common discourse that is focused on a positive and aspirational end goal, centred on the idea of justice; (2) a more progressive discourse to emerge, which focuses on the capabilities of regions and territories to develop and succeed; and (3) plural understandings of development, justice, well-being and the 'good life' to be imagined and brought to life.

\section{Spatial Justice-Review of Academic and Policy Discussions of the Concept}

Our aim in this section is to use and extend existing literatures on spatial justice as a way of articulating an alternative approach to engaging with territorial inequalities, in both academic and, especially, policy contexts. We maintain that the concept and idea of spatial justice throughout its history has been primarily focused on an urban scale ${ }^{1}$ but has the potential to make a useful contribution to understanding the unequal distribution of economic resources, public services and well-being at other geographical scales, not least the regional scale, particularly in relation to the spatial policies of the European Union. We conclude by arguing that a revised account of spatial justice, incorporating academic discussions on human capabilities and agency could 
be formulated into a guiding principle for a new spatialisation of the European Social Model.

Reviewing the literature on spatial justice demonstrates that there have been two main periods of academic and policy engagement with the idea of spatial justice (see Fig. 2). The first period began in the late 1960s and the early 1970s, while the second happened in the new millennium. The first period is marked by the publication of certain seminal books applying the ideas of social justice to geographical thought and the latter period, from 2010 onwards, is characterised by almost an exponential increase in the volume of publications addressing spatial justice. One of the first popular entries for the concept of justice that uses a spatial referent was made by Davies (1968) who focused on assessing the distribution of local services with respect to the needs of designated service areas. A few years later, Lefebvre (1970) conceptualised in La Révolution Urbaine the fundamental political and social changes needed in order to secure a spatially just society. Lefebvre's definition of justice fundamentally relied on his notion of social transformation that manifests itself mainly in cities and the urban context. Harvey $(1973,306)$ emphasised the urban context even further by noting that the urban would not only serve as the culmination of the

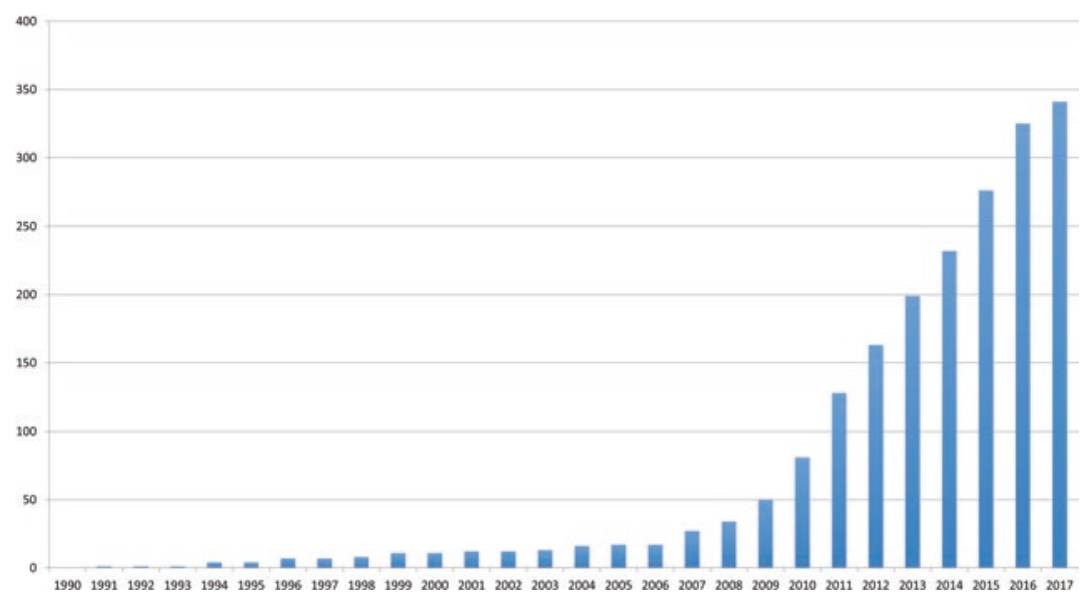

Fig. 2 The cumulative number of hits for the term 'spatial justice' on the basis of a Google Scholar search 
spatial injustice that follows the capitalist mode of production but may be the starting point of its abolishment.

After this booming period at the turn of the 1970s, the literature on spatial justice was reinvigorated at the beginning of the 2010s as a result of the publication of books on The Just City by Fainstein (2010) and on Seeking Spatial Justice by Soja (2010; Barnett 2018). Fainstein approaches the idea of spatial justice from the perspective of urban planning and argues, inspired by Rawls (1971), for the consideration of at least three components of a just city, focusing on: first, the distributive aspect when stressing the need for material equality across space; second, the need for urban social life to be characterised by diversity; and third, the central role to be played by democracy in navigating potential social and spatial conflicts. In many respects, Soja (2010) echoes many of the points made by Fainstein and others. In his seminal book, Soja uses the struggle between the Bus Riders Union and the Metropolitan Transport Authority in Los Angeles as a case study in order to build a general argument about spatial rights and the processes that help to create spatial injustice in urban space.

A number of common themes arise in relation to these studies. First of all-and as can be seen from the above studies-there has been a sustained engagement with spatial justice through the lens of the city and the urban scale. Cities have been viewed as manifestations of the economic inequalities that characterise modern society, as well as acting as key sites within which alternative and just socio-spatial forms can be imagined. And yet, there is no necessary link between spatial justice and the urban scale. Merrifield and Swyngedouw (1997, 3), in this respect, criticise a prevailing static nature of the concept of spatial justice that does not take into account spatial, temporal and scalar differences. Soja $(2010,20)$, too, claims that "justice and injustice are infused into the multiscalar geographies in which we live, from the intimacies of the household to the uneven development of the global economy" (see also Israel and Frenkel 2017,4). In short, we should not view spatial justice as something that is merely articulated through reference to the urban scale. At the same time, this does not mean that spatial justice plays out in exactly the same way at different scales. As such, we should also attend to the difference that scale might make to the forms and processes associated with spatial justice. 
Second, authors writing on spatial justice draw attention to the way in which social and spatial forms of injustice can be linked to structural inequalities of different kinds. Dikeç $(2001,1793)$ conceptualises the relation between space and justice as fundamentally bound to stable structures. In his works on French urban policy, he contends that "institutional structures and practices that privilege competition, efficiency, and economic success" play a role in establishing the conditions under which neoliberalism may thrive (Dikeç 2006, 64). For him, spatial (in)justice cannot be attributed to specific acts but is the product of systematic exclusion and dominance (Dikeç 2001). Although writing from a different perspective, Young $(2011,52)$ too, has elaborated on notions of "structural injustice", which she claims to exist "when social processes put large groups of persons under systematic threat of domination or deprivation of the means to develop and exercise their capacities, at the same time that these processes enable others to dominate or to have a wide range of opportunities for developing and exercising capacities available to them". There is considerable merit to these kinds of approaches but there is a danger that they can also create a vision of injustice as something that lies beyond any kind of agency. If injustice is so structurally embedded, then how can individuals or agencies meaningfully seek to redress it through the promotion of policies or strategies based on ideas of spatial justice?

Third, various authors have used the idea of spatial justice, not surprisingly, as a means of charting the associations between social inequalities and geographical understandings of space. While Pirie (1983) has questioned the necessity of introducing a spatial point of reference to understandings of justice, others contend that space and justice are intertwined. Space, at one level, can be thought of as something that is reflective of inequalities and injustices. Landscapes represent one kind of material and symbolic representation of such injustices (Mitchell 2003, 788). At the same time, landscape does not just mirror social processes. Nor is landscape an enigmatic "palimpsest" (Sahr 2003, 21), a "spoor" (Mitchell 2003, 790) or even the "detritus" (ibid.) of social life. Landscapes, along with other kinds of spaces, are constitutive of inequalities and injustices. It is in this context that Dabinett (2011, 2391) has argued that we should avoid seeing space as merely being a 
container for justice or, in other words, of spatial justice being "shorthand for social justice in space". Rather, we need to consider how space can influence forms of (in)justice in various far-reaching ways.

Fourth, research on spatial justice illustrates the need to consider the extent to which individuals and places of different kinds possess the rights, the capabilities or the capacity to be able to shape more just social and economic forms. Lefebvre and other "right to the city" scholars during the late 1960s and early 1970s, for instance, conceived of spatial justice as being "a right to/or access to" something. Lefebvre, in this respect, claimed that justice could not be reduced to access to resources but rather involved the right to take part in urban transformation processes. Justice, in this regard, implies "active participation in the political life, management and the administration of the city" (Dikeç 2001, 1790). In a more recent contribution, Israel and Frenkel (2017) have drawn on the capabilities approach of Sen $(1993,2009)$ in order to develop a notion of justice that derives from a "person's capabilities and his liberties" (Israel and Frenkel 2017, 2). And of course, it is possible to extend this notion of justice by viewing spatial justice as something that reflects a particular place's, locality's, region's or state's capabilities or liberties. It is in this context that ideas of political representation and capacity assume great significance.

Finally, work on spatial justice highlights the need to examine the pluralities of understandings of justice. While some universal goalssuch as freedom, liberty and well-being-may be constant, authors such as Sen (2009) have argued that we should guard against presupposing a uniform notion of a perfectly just situation against which reality is to be measured. For example, Israel and Frenkel (2017) note that as no single definitive measure exists for justice, it should be assessed on the basis of individual opportunities in a given context. A more choice-centred understanding of what is fair and what may create well-being, therefore, needs to come into play (Sen 1993). And of course, this is not solely agent-centred but also place-centred. So, according to Storper $(2011,19)$, while "freedom and liberty; the ability to live our lives and be happy; and development of our capabilities" may well be common goals, "different individuals, groups and territories might fill in the detail on these goals in rather different ways". 
Thinking about spatial justice in such plural ways also raises significant questions in relation to how we might go about measuring variations in justice and well-being; in ways that go beyond simple measures of GDP (Stiglitz et al. 2009).

Despite this rich and recently reinvigorated body of academic literature on spatial justice, its implications for EU policies relating to spatial inequalities, including territorial cohesion, have been underexplored to date. Part of the reason for this lack of engagement may well derive from the fact that academic discussions about spatial justice have mainly addressed the urban scale and, as such, have not found their way on to EU policy agendas operating mainly on a regional (or territorial) scale. But, as we have shown above, there are no a priori reasons why understandings of spatial justice should not be usefully applied at other scales, including those that are relevant to EU policies targeting spatial (in) equality.

In sum, we argue that the spatialisation of spatial justice in the name of territorial cohesion policy has remained partial. Influenced by the coupling of the European Social Model and the EU's global economic competitiveness in the early 2000s, EU's territorial cohesion policies have been far too strongly dominated by particular economic geographical discourses of growth and regional differentiation for well over a decade. As a result, there has been tendency for cohesion policies to focus almost invariably on regional disparities and regional competitiveness-related issues. But given that the emphasis on "regions" is one of the peculiarities of the EU as a polity, the small impact of scholarly work on urban spatial justice and injustice on cohesion policies may not come as a terrible revelation.

It is for the above-mentioned reasons that we proceed in the final section of this chapter to outline some potential benefits accruing from adopting a language of spatial justice as a way of thinking creatively and differently about the European Union's policies relating to spatial inequalities. We also provide a brief outline of a research project, with which we as authors are associated, that is examining the potential of using spatial justice as a way of developing new policy solutions to the entrenched socio-spatial inequalities that characterise contemporary Europe. 


\section{From Territorial Cohesion to Spatial Justice: A New Agenda for the Empowered Regions of the European Union?}

While we do not believe that the notion of spatial justice will necessarily provide a panacea for addressing socio-spatial inequalities within Europe, we believe that it has the potential to explore other avenues and approaches that might prove to be more successful than those currently being used. First, we maintain that paying more attention to the concept of spatial justice can allow academics, policy-makers and the public alike to be enrolled more readily into regional coalitions of interest, capable of addressing inequalities. The discourse of justice is one that is meaningful and accessible to different stakeholders, and also allows connections to be made between demands for spatial justice and pre-existing struggles for other kinds of justice, whether in relation to the environment, gender and so on. It is a language and discourse, therefore, that have the potential to be flexible and inclusive, encompassing many different aspects of life and work. Using a discourse of spatial justice can also allow stakeholders within regions and beyond to coalesce around the delivery of a positive set of end goals instead of merely fighting against negative conditions. The discursive limitations of other alternative discourses are apparent when one thinks in such ways; it may be easier, for instance, to fight for justice than it is to fight for 'de-peripheralisation' or more even forms of development.

Second, using the concept of spatial justice can enable a more progressive discourse to emerge, which focuses on the capabilities of regions and territories to develop and succeed, rather than being a discourse that views regions and territories as ones that exist merely to receive financial and institutional support from others. Approaching spatial justice as something that is based on "right to" rather than "regional distribution of" would necessitate an alternative approach to reducing socio-spatial inequalities within Europe, one that would be less concerned with an interregional redistribution of economic resources than it would be with providing regions with the necessary capacity to shape their own socio-spatial futures. Viewing spatial justice in terms of 
capabilities does not necessarily provide a simple solution to the challenges facing 'under-performing' regions. After all, creating additional capabilities among such regions-whether in terms of granting greater political power, increased capacity to tax and spend, or an increased ability to create new institutional fixes - is not always easy, especially if it involves a transfer of power from other polities. Nor will the various ways of increasing a region's capabilities, outlined above, necessarily lead to a situation in which such regions will be able to pursue their socio-economic goals more effectively. As we noted in the previous section, there are many structural factors that can impede the ability of a region to succeed, no matter how much capacity is devolved to that region. And yet, we believe that there is a value in focusing on the capabilities aspect of spatial justice and on its implications for the European Union's spatial policies, namely the way in which it refocuses the terms of the debate away from viewing regions as being almost helpless receivers of aid to being active shapers of their own socio-economic destinies.

Third, the use of the concept of spatial justice allows us to envisage how plural understandings of development, justice, well-being and the 'good life' might be developed, ones that are attuned to the regions and territories from which they emanate. The idea of capabilities and agency by Sen starts with an acknowledgement that justice and well-being manifest themselves differently in various spatial contexts. Engaging with spatial justice, therefore, does not force regions onto a single trajectory based on assumptions of a direct and linear relationship between economy and well-being. Rather, thinking in such ways opens up the possibility for different regions to develop alternative conceptions of what might constitute well-being for those individuals and groups living and working within those regions. Using spatial justice in such a way may also be less problematic as a normative policy aim than other alternatives such as assisting lagging regions so that they might "catch up" with the best-performing regions or the EU average.

While the above statements are tentative in nature, there is some limited evidence of how certain territories and regions in Europe are beginning to think in different ways about issues relating to development, justice and well-being. Recent attempts to develop inclusive and alternative visions of long-term sustainable futures in different parts of 
Europe-for example, in relation to attempts to define the Wales we want (Jones and Ross 2016)_show how certain national and regional governments are seeking to develop dialogues with relevant stakeholders in order to create plural and long-term conceptions of 'development', 'well-being' and 'justice'. Although these conversations are in their early stages, they begin to illustrate the potential associated with engaging with notions of territorial inequality in different ways. These conversations have: (1) been focused around ideas of justice, well-being and sustainable development, precisely because these concepts have provided a language around which different stakeholders have been able to coalesce; (2) asserted that there is a need for states and regions to use their own capacity to define their vision of long-term futures that are characterised by well-being and justice; and (3) articulated visions of long-term futures that reflect the specific priorities that exist within their own territories and populations. There is some scope, we suggest, for the European Union to harness these emerging attempts to define long-term future visions of social and spatial justice as part of its potential attempts to address spatial inequalities.

Of course, the above suggestions are, at present, rather speculative in nature. There is a need to conduct research on the potential for these ideas to deliver a more progressive and successful future for various regions in Europe. As we noted earlier, the authors of this chapter are all involved in a multi-partner and inter-disciplinary research project, funded as part of the Horizon 2020 programme, which is examining the role that ideas of spatial justice might play in understanding and challenging socio-spatial inequalities in Europe (http://imajine-project. $\mathrm{eu}$. The project is: (1) examining conceptual approaches to understanding inequalities in contemporary Europe; (2) developing more detailed ways of mapping different kinds of inequality; (3) charting the challenges facing different regions in relation to service delivery; (4) interrogating the link between socio-spatial inequalities and migration at different scales; (5) examining the connection between inequalities and political representation and mobilisation; and (6) working with various stakeholders to enable them to imagine alternative futures for their regions. While the project is in its early stages, our hope is that it will contribute in far-reaching ways to academic understandings of spatial 
justice, as well as allowing us to contribute to emerging debates within various European institutions about the potential policy benefits associated with an engagement with spatial justice.

Evidently, there is a real need to engage effectively with such issues. Even if what one may term the golden years of European-level discourses of territorial cohesion may well be on the wane, there is an urgent need for a new round of cohesion policies to address the politics of austerity, the rise of right-wing populism in Europe, and a deepening of the legitimacy crisis of the European Union. And yet, our argument in this chapter is that there may be useful alternatives to the previous rounds of territorial cohesion policies, which might help to spatialise the European Union's Social Model in more effective ways, thus contributing more directly to the well-being and welfare of people in various parts of Europe. We contend that the academic literatures on spatial justice, human capabilities and agency point to one potentially fruitful way of achieving these goals.

\section{Note}

1. However, it should be mentioned that spatial justice arguments have also been applied in diverse ways to racial or environmental justice literatures at widely differing geographical scales. Nonetheless, the geographical literature on spatial justice has tended to focus either implicitly or explicitly on the urban scale.

\section{References}

Abrams, Gareth. 2014. "What 'Is' Territorial Cohesion? What Does It 'Do'?: Essentialist Versus Pragmatic Approaches to Using Concepts." European Planning Studies 22 (10): 2134-55. https://doi.org/10.1080/09654313.20 13.819838 .

Allen, David. 2005. "Cohesion and the Structural Funds: Competing Pressures for Reform?" In Policy-Making in the European Union, edited by Helen Wallace, William Wallace, and Mark Pollack, 5th ed., 213-41. Oxford: Oxford University Press. 
Atkinson, Rob, and Karsten Zimmermann. 2016. "Cohesion Policy and Cities: An Ambivalent Relationship?" In Handbook on Cohesion Policy in the $E U$, edited by Simona Piattoni and Laura Polverari, 413-26. Cheltenham: Edward Elgar.

Barca, Fabrizio. 2009. "An Agenda for a Reformed Cohesion Policy: A PlaceBased Approach to Meeting European Union Challenges and Expectations." Independent Report Prepared at the Request of the European Commissioner for Regional Policy, Danuta Hübner, European Commission, Brussels. http://www.europarl.europa.eu/meetdocs/2009_2014/documents/regi/dv/ barca_report_/barca_report_en.pdf.

Barnett, Clive. 2018. "Geography and the Priority of Injustice." Annals of the Association of Geographers 108 (2): 317-26. https://doi.org/10.1080/246944 52.2017.1365581.

Dabinett, Gordon. 2011. "Promoting Territorial Cohesion and Understandings of Spatial Justice.” Paper for the DG Regio, Regional Studies and Slovenia Government Office for Local Self-Government and Regional Policy Conference: What Future for Cohesion Policy? An Academic and Policy Debate. 16-18 March 2011, Sava Hoteli Bled, Slovenia.

Davies, Bleddyn P. 1968. Social Needs and Resources in Local Services: A Study of Variations in Provision of Social Services Between Local Authority Areas. London: Joseph Rowntree.

Davoudi, Simin. 2005. “Understanding Territorial Cohesion.” Planning Practice \& Research, 20 (4): 433-41. https://doi.org/10.1080/02697450600767926.

Davoudi, Simin. 2007. "Territorial Cohesion, the European Social Model, and Spatial Policy Research." In Territorial Cohesion and the European Model of Society, edited by Andreas Faludi, 81-103. Cambridge: Lincoln Institute for Land Policy.

Dikeç, Mustafa. 2001. "Justice and the Spatial Imagination.” Environment and Planning A: Economy and Space 33 (10): 1785-805. https://doi. org/10.1068/a3467.

Dikeç, Mustafa. 2006. “Two Decades of French Urban Policy: From Social Development of Neighbourhoods to the Republican Penal State." Antipode 38 (1): 59-81.

ESPON. 2004. "ESPON in Progress: Preliminary Results by Autumn 2003.” Luxembourg. https://www.espon.eu/sites/default/files/attachments/ ESPON_synthesis_report_I.pdf.

European Commission. 1994. "European Social Policy-A Way Forward for the Union.” A White Paper. COM (94) 333 final, Commission of the European Communities, Brussels. 
European Commission. 2001. "Unity, Solidarity, Diversity for Europe, Its People and Its Territory. Second report on Economic and Social Cohesion." Luxembourg: Office for Official Publications of the European Communities.

European Commission. 2004. "A New Partnership for Cohesion. Convergence, Competitiveness, Cooperation. Third Report on Economic and Social Cohesion." Luxembourg: Office for Official Publications of the European Communities.

European Commission. 2017. "My Region, My Europe, Our Future. Seventh Report on Economic, Social and Territorial Cohesion." Luxembourg: Publications Office of the European Union. http://ec.europa.eu/regional_ policy/sources/docoffic/official/reports/cohesion7/7cr.pdf.

Evers, David. 2008. "Reflections on Territorial Cohesion and European Spatial Planning." Tijdschrift voor Economische en Sociale Geografie 99 (3): 303-15. https://doi.org/10.1111/j.1467-9663.2008.00463.x.

Fainstein, Susan S. 2010. The Just City. Ithaca: Cornell University Press.

Faludi, Andreas. 2004. "Territorial Cohesion: Old (French) Wine in New Bottles?” Urban Studies 41 (7): 1349-65. https://doi.org/10.1080/004209 8042000214833.

Faludi, Andreas. 2005. "Polycentric Territorial Cohesion Policy." The Town Planning Review 76 (1): 107-18.

Faludi, Andreas. 2010. Cohesion, Coherence, Cooperation: European Spatial Planning Coming of Age? London: Routledge.

Faludi, Andreas. 2015. "Territorial Cohesion Under the Looking Glass. Synthesis Paper About the History of the Concept and Policy Background to Territorial Cohesion.” EU Publications. https://publications.europa.eu/ en/publication-detail/-/publication/15dd2ed8-9d76-49f2-994e-775b77f0d 40a/language-en.

Faludi, Andreas, and Bas Waterhout. 2005. "The Usual Suspects: The Rotterdam Informal Ministerial Meeting on Territorial Cohesion." Tijdschrift voor Economische en Sociale Geografie, 96 (3): 338-42. https://doi. org/10.1111/j.1467-9663.2005.00463.x.

Hadjimichalis, Costis. 2019. “'New' Questions of Socio-Spatial Peripherality in Europe." In Regional and Local Development in Times of PolarizationRe-thinking Spatial Policies in Europe, edited by Thilo Lang and Franziska Görmar. Palgrave Macmillan.

Harvey, David. 1973. Social Justice and the City. Athens: University of Georgia Press. Holder, Jane, and Antonia Layard. 2011. "Drawing out the Elements of Territorial Cohesion: Re-scaling EU Spatial Governance." Yearbook of European Law 30 (1), 358-80. https://doi.org/10.1093/yel/yer016. 
Hübner, Danuta. 2005. "Solidarity in the European Constitution." Speech at the Conference 'European Constitution and Solidarity'. Brussels, 15 February. http://europa.eu/rapid/press-release_SPEECH-05-95_en.pdf. Israel, Emil, and Amnon Frenkel. 2017. "Social Justice and Spatial Inequality: Toward a Conceptual Framework." Progress in Human Geography. https:// doi.org/10.1177/0309132517702969.

Jones, Rhys, and Andrea Ross. 2016. "National Sustainabilities." Political Geography 51: 53-62. https://doi.org/10.1016/j.polgeo.2015.12.002.

Lefebvre, Henri. 1970. La Révolution Urbaine. Paris: Gallimard.

Luukkonen, Juho, and Sami Moisio. 2016. "On the Socio-Technical Practices of the European Union Territory." Environment and Planning A: Economy and Space 48 (8): 1452-72. https://doi.org/10.1177/0308518X16641413.

Merrifield, Andy, and Erik Swyngedouw. 1997. "Social Justice and the Urban Experience: An Introduction." In The Urbanization of Injustice, edited by Andy Merrifield and Erik Swyngedouw, 1-17. New York: New York University Press.

Mirwaldt, Katja, Irene McMaster, and John Bachtler. 2008. "Reconsidering Cohesion Policy: The Contested Debate on Territorial Cohesion.” EoRPA Paper 08/5, University of Strathclyde, Glasgow.

Mitchell, Don. 2003. "Cultural Landscapes: Just Landscapes or Landscapes of Justice?” Progress in Human Geography 27 (6): 787-96. https://doi.org/10.1 191/0309132503ph464pr.

Pirie, Gordon H. 1983. "On Spatial Justice." Environment and Planning A: Economy and Space 15 (4): 465-73. https://doi.org/10.1068/a150465. Rawls, John. 1971. A Theory of Justice. Cambridge: Harvard University Press. Sahr, Wolf-Dietrich. 2003. "Zeichen und RaumWELTEN - zur Geographie des Kulturellen." Petermanns Geographische Mitteilungen 147: 18-27.

Sarmiento-Mirwaldt, Katja. 2015. "Can Multiple Streams Predict the Territorial Cohesion Debate in the EU?" European Urban and Regional Studies 22 (4): 431-45. https://doi.org/10.1177/0969776413481984.

Schön, Peter. 2005. “Territorial Cohesion in Europe?" Planning Theory \& Practice 6 (3): 389-400. https://doi.org/10.1080/14649350500209397.

Sen, Amartya. 1993. "Capability and Well-Being." In The Quality of Life, edited by Martha C. Nussbaum and Amartya Sen, 30-53. Oxford: Clarendon Press.

Sen, Amartya. 2009. The Idea of Justice. Cambridge: Harvard University Press. Servillo, Loris. 2010. "Territorial Cohesion Discourses: Hegemonic Strategic Concepts in European Spatial Planning." Planning Theory \& Practice 11 (3): 397-416. https://doi.org/10.1080/14649357.2010.500135. 
Soja, Edward W. 2010. Seeking Spatial Justice. Minneapolis: University of Minnesota Press.

Stiglitz, Joseph E., Amartya Sen, and Jean-Paul Fitoussi. 2009. Mismeasuring Our Lives: Why GDP Doesn't Add Up. New York: The New Press.

Storper, Michael. 2011. "Justice, Efficiency and Economic Geography: Should Places Help One Another to Develop?" European Urban and Regional Studies 18 (1): 3-21. https://doi.org/10.1177/0969776410394553.

TAEU-Territorial Agenda of the European Union. 2007. "Towards a More Competitive and Sustainable Europe of Diverse Regions." Agreed on the Occasion of the Informal Ministerial Meeting on Urban Development and Territorial Cohesion in Leipzig on 24/25 May 2007. http://ec.europa.eu/ regional_policy/sources/policy/what/territorial-cohesion/territorial_agenda_ leipzig2007.pdf.

Young, Iris M. 2011. Responsibility for Justice. Oxford: Oxford University Press.

Open Access This chapter is licensed under the terms of the Creative Commons Attribution 4.0 International License (http://creativecommons. org/licenses/by/4.0/), which permits use, sharing, adaptation, distribution and reproduction in any medium or format, as long as you give appropriate credit to the original author(s) and the source, provide a link to the Creative Commons license and indicate if changes were made.

The images or other third party material in this chapter are included in the chapter's Creative Commons license, unless indicated otherwise in a credit line to the material. If material is not included in the chapter's Creative Commons license and your intended use is not permitted by statutory regulation or exceeds the permitted use, you will need to obtain permission directly from the copyright holder.

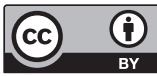




\title{
6
}

\section{Questioning the Convergence of Cohesion and Innovation Policies in Central and Eastern Europe}

\author{
Bradley Loewen and Sebastian Schulz
}

\section{Introduction}

As EU Cohesion Policy has become focused on economic competitiveness and growth in less favoured regions, measures that traditionally were in the realm of Innovation Policy have emerged, raising questions about the compatibility, complementarity and even necessity of these two policy streams in reaching Cohesion Policy goals. Through the Regional Innovation Systems literature, in particular, innovation has emerged as a key factor in regional development. As innovation began to infiltrate Cohesion Policy, a debate has arisen about the compatibility of these two policy areas for less developed target regions, since it is rather the highly developed cores that are poised to benefit the most from a regional policy based on innovation capacities. This has implications for Central

B. Loewen $(\square)$

University of Economics, Prague, Czech Republic

S. Schulz

University of Tartu, Tartu, Estonia

(C) The Author(s) 2019

T. Lang and F. Görmar (eds.), Regional and Local Development

121

in Times of Polarisation, New Geographies of Europe,

https://doi.org/10.1007/978-981-13-1190-1_6 
and Eastern European (CEE) countries, which are experiencing strong patterns of regional polarisation (Kühn 2015; Lang et al. 2015). CEE countries are heavily dependent on Cohesion Policy interventions for regional development, which are shaped by increasing conditionality and are becoming closely associated with innovation strategies themselves. Through EU integration leading up to the European Union's eastern expansion, member states held uneven positions in a multi-scalar system in shaping supranational policies and expertise (see Hudson 2003; Kuus 2011), which would potentially put countries like those in CEE that are heavily dependent on European core economies at a disadvantage in shaping the policies that target their own development such as Cohesion Policy. Despite progress towards economic convergence between CEE countries since accession, other events such as the financial crisis have furthered regional polarisation across Europe, calling into question the effectiveness of these supranational European policies in less favoured regions (European Commission 2013, 2014, 2017; Hadjimichalis 2011; Hadjimichalis and Hudson 2014).

In the following, national policies in Czechia, Estonia, Hungary and Slovakia are investigated to assess how the interrelations of supranational EU policies-Cohesion Policy and Innovation Policy-have unfolded in CEE countries. The subject matter and empirical results form a contribution of the Marie Curie Initial Training Network, "RegPol2-Socio-economic and Political Responses to Regional Polarisation in Central and Eastern Europe". These four countries, amongst others in CEE, emerged from similar socialist legacies but followed different institutional and policy trajectories through their transitions (Stark and Bruszt 1998; Bohle and Greskovits 2007), joining the EU through parallel accession processes that availed Cohesion Policy as a significant development tool. Nevertheless, they have followed different institutional and policy trajectories, which provides an opportunity to investigate various national responses to and impacts of supranational policies. After presenting the overarching policy frameworks, the analysis compares policy-related programming documents such as strategic reference frameworks, partnership agreements and operational programmes (OPs), which are complemented by interviews of policy experts in the four countries, to determine whether the generally 
observed convergence of Cohesion and Innovation Policy can be beneficial for addressing regional polarisation in different types of $\mathrm{CEE}$ countries.

\section{The Evolution of Supranational European Policy}

The expansion of the EU to include the post-socialist CEE countries has been faced with the challenge of integrating regions of starkly different levels of economic development. This problem persists to this day through regional polarisation and peripheralisation processes resulting, in part, from the integration of all regions in the EU into the single economic market. As the balance of population and economic activity of the European Market moved eastwards following its 2004 expansion, the description of the average European region adjusted to reflect the relatively low economic productivity and institutional legacies of the so-called new member states. The EU would expand by approximately one quarter in territory and one fifth in population, but the total GDP would only stand to increase by 5\% (European Commission 1997). In consequence, Cohesion Policy was reformed to benefit most regions in CEE, drawing substantial investment away from Southern Europe, in an attempt to offset the negative economic consequences of EU integration on the least developed regions. As conditionality for drawing EU funds and in adherence to the partnership principle, Cohesion Policy goals were translated into national development plans in CEE countries for the use of European funds through strategic frameworks for investment negotiated with the European Commission and further elaborated in Operational Programmes.

Always attracting the attention of academics and policy-makers, Cohesion Policy has been the subject of much debate, not least because the coming of each seven-year programming period offers a fresh possibility for reform. As such, the ideals of Cohesion Policy have been subject to both radical and incremental reforms in recent decades (Mendez 2012), including the reorientation of Cohesion Policy towards the Lisbon Agenda of 2000 and its economic competitiveness 
and growth objectives (Mendez 2011), in an attempt to condition the EU for globalisation after Eastern enlargement. Key documents in the reform of Cohesion Policy are listed in Table 1. In adhering to the focus of this chapter on the post-socialist period, we approximate three EU policy periods to structure the development of Cohesion Policy and Innovation Policy: the 'Europe of the Regions' period of the 1990s to early 2000s; the Lisbon Agenda period of approximately 2000-2010; and the Europe 2020 period of approximately 2010-2020.

\subsection{The Europe of the Regions}

While not an official EU policy, the 'Europe of the Regions' slogan represented a suite of policies and institutional changes associated with experimental governance practices backed by subsidiarity and

Table 1 Key reports influencing cohesion policy in CEE countries

\begin{tabular}{|c|c|c|}
\hline Year & Document & Author \\
\hline 1997 & $\begin{array}{l}\text { Agenda 2000: For a stronger and wider } \\
\text { Union }\end{array}$ & European Commission \\
\hline 1999 & $\begin{array}{l}\text { ESDP_European Spatial Development } \\
\text { Perspective }\end{array}$ & European Commission \\
\hline 2003 & $\begin{array}{l}\text { An agenda for a growing Europe: Making } \\
\text { the EU economic system deliver (Sapir } \\
\text { Report) }\end{array}$ & Sapir et al. \\
\hline 2004 & $\begin{array}{l}\text { Facing the challenge: The Lisbon strat- } \\
\text { egy for growth and employment (Kok } \\
\text { Report) }\end{array}$ & European Commission \\
\hline 2005 & $\begin{array}{l}\text { Working together for growth and jobs- } \\
\text { A new start for the Lisbon Strategy } \\
\text { (Barroso communication) }\end{array}$ & European Commission \\
\hline 2009 & $\begin{array}{l}\text { An Agenda for a Reformed Cohesion } \\
\text { Policy (Barca Report) }\end{array}$ & Barca \\
\hline 2009 & $\begin{array}{l}\text { The White Paper on Multi-level } \\
\text { Governance }\end{array}$ & Committee of the Regions \\
\hline 2010 & $\begin{array}{l}\text { Europe 2020: A strategy for smart, sus- } \\
\text { tainable and inclusive growth }\end{array}$ & European Commission \\
\hline 2014 & $\begin{array}{l}\text { Investment for jobs and growth: } \\
\text { Promoting development and good gov- } \\
\text { ernance in EU regions and cities (Sixth } \\
\text { Cohesion Report) }\end{array}$ & European Commission \\
\hline
\end{tabular}


partnership principles, thereby driving regionalisation processes. According to Loughlin (1996), amidst discussions of European federalism in the 1990s, the rise of the 'regional question' was partly about reclaiming regional policy from central governments. The concept of a 'Europe of the Regions' articulated the potential for EU-regional relations and laid the groundwork for regional competition (Borrás-Alomar et al. 1994). The European development strategy Agenda 2000 identified ambitious projects including enlargement, the adoption of the euro and the creation of the single market, as well as mentioning strategies for tackling regional problems of industrial restructuring by way of technology infiltration, human skills development and SME support (European Commission 1997). Meanwhile, the European Spatial Development Perspective formalised regionalisation and territorial cohesion as core to Cohesion Policy, furthering the institutionalisation of European spatial planning processes for targeting regional inequalities (European Commission 1999). Here, we begin to see potentials for coordination between Cohesion and Innovation Policy. The translation of such experimental governance models, economic restructuring strategies and territorial development objectives to CEE countries, nevertheless, would come to present new challenges for implementation and raise new questions about the policy priorities in CEE.

In terms of Innovation Policy, the EU started to 'Europeanise' the production of scientific and technological knowledge from the 1980s through its Framework Programmes, which aimed to foster research and technology across member states and strengthen competitiveness (Borrás 2003). During the pre-accession period, the EU intensified its ambitions to develop an Innovation Policy that would acknowledge the cohesion objective in less favoured regions and contribute to the EU's innovation capacities (Lagendijk 2011). Out of these considerations, the EU created a joint programme of regional and industrial policy based on the EU's Innovation Programme and Article 10 of the ERDF, resulting in the launch of Regional Technology Plans (RTP) for less-favoured NUTS 2 regions and Regional Innovation and Technology Transfer Strategies (RITTS) focused on innovation support structures for increasing competitiveness in all regions. Moreover, networking and knowledge transfer arrangements such as the Innovating Regions 
in Europe network (IRE) and its associated Mutual Learning Platform enabled implementation and diffusion of the RIS methodology across EU regions (European Commission 1994). Thus, the first innovation support programmes began to address spatial differences in innovation capacity and competitiveness.

\subsection{The Lisbon Agenda}

Lagging productivity with international competitors led to the Lisbon Agenda of 2000 for promoting economic competitiveness and growth in the EU, drawing together Cohesion Policy and Innovation Policy in a coordinated European strategy intended to integrate across sectoral policies (see Sapir et al. 2003; European Commission 2004). After lacklustre results, the Lisbon Agenda was relaunched in 2005, further emphasising innovation and entrepreneurship to encourage growth (European Commission 2005). Meanwhile, the Eastern enlargement and the financial crisis further contributed to the debate on Cohesion Policy reform during the 2007-2013 programming period, resulting in the promotion of a place-based development model as a means for delivering both traditional cohesion and Lisbon-related growth objectives (Barca 2009; Farole et al. 2011).

The 'Lisbonisation' of Cohesion Policy strengthened the orientation, monitoring and evaluation of results, and showed multiple paths amongst member states to achieving the strategic guidelines (Mendez 2011). Nevertheless, by concentrating regional development programmes towards economic rather than social and environmental interventions, cohesion came to be increasingly defined in terms of productivity and competitiveness complementary to a broad-based innovation strategy. The debate on Cohesion Policy reform during the Lisbon era foresaw contradictions in crossing a place-based Cohesion Policy with a spatially blind Innovation Policy, finding potential for "perverse dynamic structural effects" and "divergent capacities to engage in development" (Farole et al. 2011, 1097).

Despite the controversy, the Lisbon Agenda was supported by the Committee of the Regions due to the strengthened role of regions 
in the design and implementation of Cohesion Policy. Thus, the Lisbon Agenda was integrated into its conceptualisation of multilevel governance in an attempt to circumvent the strategy's top-down nature (Committee of the Regions 2009). Others agreed that the regions played an important role in the 'Lisbonised' policy to combat underdevelopment (Farole et al. 2011). Nevertheless, decentralisation of regional policy had its downfalls. The multiplication of regional Operational Programmes during the 2007-2013 programming period placed greater demands on the regional (NUTS-2) levels, testing their institutional capacities. The disappointing results of the period, stemming from administrative burden, delayed implementation and low absorption due to pressures of the financial crisis on public expenditures, would lead to greater centralisation and tighter controls in the following programming period (European Commission 2013).

Innovation became a central theme in the Lisbon Agenda and Cohesion Policy, which, according to Lagendijk and Varró (2013), led to three major trends of policy integration. First, Cohesion Policy and Community programmes such as Interreg moved larger amounts of funds to innovation-oriented measures (European Commission 2006). Second, industrial and regional policies were increasingly connected through the elaboration of 'place-based' cluster approaches (Barca 2009). Third, an idea was put forward to connect research policy (including the European Research Area) to 'place-based' innovation approaches (Soete 2009). These moves aimed at building a stronger alignment of regional policy, industrial policy and research policy, in view of the Lisbon Agenda's main ambitions to strengthen the Union's competitiveness and cohesion. Nevertheless, the Eastern expansion of the EU slowed down the adoption of 'place-based' approaches in innovation policy, since most accession countries in CEE lacked sub-national governance structures. At the same time, the principles of efficiency, management and accountability were more strongly emphasised in policy-making, since more countries were now eligible for structural support. In response, the EU re-emphasised a more centralised approach to implement Cohesion Policy (Bachtler and McMaster 2008). 


\subsection{Europe $\mathbf{2 0 2 0}$}

The Europe 2020 strategy effectively succeeded the Lisbon Agenda in renewing competitiveness and growth objectives for the 2014-2020 programming period. The strategy for "smart, sustainable and inclusive growth" (European Commission 2010) responded to issues exacerbated by the economic crisis, such as the de-growth that was occurring in some regions (Lois González 2013). Regional development strategies were to be driven by the concept of Smart Specialisation, which attempts to translate a sectoral concept to a spatial context, bridging the EU's Innovation Union strategy with Cohesion Policy (McCann and Ortega-Argilés 2013). The Innovation Union is a so-called 'flagship initiative' to implement the Europe 2020 strategy, whose proclaimed overarching goal is to enshrine a focus on innovation in a variety of political instruments, measures and funds to improve framework conditions for knowledge-intensive products and services.

In their analysis of the Europe 2020 strategy, Avdikos and Chardas (2016) interpret diminishing cohesion through convergence and enhanced place-based growth that "ignores the uneven relations of regions and localities in capitalism production" (p. 110) and "emphasizes 'soft' factors of development" (p. 111) such as knowledge and innovation capacities, calling for strong reservations over place-based policies. This comes after reviews of territorial development policies and programmes showed increasing regional disparities throughout the Lisbon era, especially in CEE (ESPON 2014; European Commission 2014). Recent research confirms these concerns, finding that the Partnership Agreements setting the national programmes for the 2014-2020 period focus on economic competitiveness rather than socio-economic convergence as the driver of Sustainable Urban Development strategies addressed through Cohesion Policy (Nosek 2017).

After launching the Innovation Union initiative and mainstreaming the Smart Specialisation approach, the focus on innovation has become a key strategic pillar in EU Cohesion Policy. Smart Specialisation aims at establishing innovation as a priority for all European regions. However, the concept's theoretical grounds are still provisional (Foray et al. 2009), and it contains a number of elements that were already 
present in the innovations systems and entrepreneurship literature (McCann and Ortega-Argilés 2013). In policy terms, the basic novelty of Smart Specialisation is that it provides a clear policy prioritisation logic that is adaptable to different types of regional settings. This is accompanied by a move towards a more differentiated view on regional opportunities, by which only certain regions can be at the frontier of research and innovation (Lagendijk and Varró 2013). Accordingly, noncore regions are supposed to find a made-to-measure way to position themselves in the global economy.

Overall, the EU is still struggling to meet the policy objectives set in the Lisbon Agenda and Europe 2020 as well as with making sure that policy efforts to reduce regional disparities among European regions are effective. Key indicators such as the number of people at risk of poverty or social exclusion worsened in recent years as a result of the financial crisis (European Commission 2014), providing further evidence for processes of regional peripheralisation (Kühn 2015; Lang et al. 2015). Some scholars argue that one of the main reasons for this trend is the asymmetric economic integration of countries into the European Union, since the productivity gap is largely of a structural nature (Avdikos and Chardas 2016; Kalman and Tiits 2014). While the more advanced member states in the EU's core specialise in high-income activities with increasing returns, such as knowledge-intensive services and medium- and high-technology manufacturing, more peripheral regions are focused on basic, less knowledge-intensive, low-income services and low- and medium-technology manufacturing (Hansen and Winther 2011). This renders a rapid catching-up of peripheral regions fairly unrealistic, even with the help of targeted policies.

Moreover, a number of elements of EU Innovation Policy-and the EU's economic policy framework on the whole-face major challenges in adequately meeting the realities and needs of all member states with different spatial structures, institutional settings and historical legacies. By putting scientific excellence and cutting-edge research first, Innovation Policy mostly helps the largest and strongest institutions in Europe. It follows that the EU and the general macroeconomic framework of the Eurozone, with its barely controlled market forces (e.g. cross-border flows of capital in the speculative finance, insurance and 
real estate sectors to quickly developing CEE markets, Kalman and Tiits 2014), played a far greater role in influencing growth in CEE countries from the 2000s than the political intent of the Lisbon Agenda or Cohesion Policy (Hadjimichalis and Hudson 2014). In spite of coordinated policy measures, peripheral regions become an alternative location for capital and business activities in times of upturn, while in times of downturn, firms and capital tend to concentrate in urban, metropolitan locations (cf. Kalman and Tiits 2014). These upturns and downturns affect cohesion, potentially furthering processes of regional polarisation.

Further to the above-described shifts in Cohesion and Innovation Policy, the question nevertheless remains, how closely do the national policies in CEE integrate the innovation agenda with Cohesion Policy? The following section analyses the development of these policies in the CEE context, drawing from national policies and reflecting upon feedback from policy experts.

\section{Cohesion Through Innovation or Cohesion Versus Innovation? National Responses from Central and Eastern Europe}

As explained above, Cohesion Policy has developed through several eras of supranational EU policy guiding regional development, and, shifting focus towards economic competitiveness, has become closely intertwined with a growth-through-innovation strategy. Turning to CEE national contexts, where regional inequalities are relatively high and significant development activities are funded through EU programmes, contradictions between policy goals, programme requirements, and capacities on the ground are most apparent.

The general orientations of domestic policies regarding cohesion and innovation can be traced through official documents, to the extent that they are formalised. The compulsory national programming documents for Cohesion Policy, therefore, provide a basis for comparing strategies between countries where cohesion and innovation may not necessarily be high-profile political objectives. The following analysis of policy 
documents supplemented by interviews with policy experts (see Appendix, Tables 3 and 4) reveals convergence tendencies between Cohesion Policy and Innovation Policy in selected CEE countries. The conflation of regional and innovation policies may, however, have different effects in countries characterised by different spatial and economic structures that pursue different strategies for growth and/or tackling regional inequalities. Indeed, shares of Cohesion Policy budgets allocated to specific thematic objectives varied widely across CEE in the 2014-2020 period, indicating different national preferences and priorities (KPMG 2016). This also has implications for Innovation Policy with respect to supporting rapid growth in the core or pursuing development activities in the peripheries.

\subsection{Competitiveness and Convergence}

National strategic documents for Cohesion Policy programmes from the three programming periods since CEE accession were analysed for elements of Innovation Policy and approaches to the competitiveness agenda (Appendix, Table 3). The results from Czechia, Estonia, Hungary and Slovakia indicate a variety of responses emerging from within shared European policy frameworks (Table 2). Prior analysis showed that competitiveness and growth were pursued through different national approaches including: service upgrading in Czechia; science, technology and entrepreneurialism in Estonia; and greater labour force participation in Hungary (Loewen 2015). In comparison, competitiveness in Slovakia has focused on utilising low-cost labour in manufacturing through FDI investments as well as service upgrading, as in the Czech case (Ministry of Construction and Regional Development 2003, 2007; Government of the Slovak Republic 2014). These cross-country differences reflect heterogeneity in size, economic structure and level of development as well as in their national development strategies and approaches to core concepts of Cohesion Policy such as socio-economic convergence.

Regarding convergence, it is important to distinguish between the spatial scales of national strategies with respect to innovation programmes and whether they are oriented towards developing cores or 


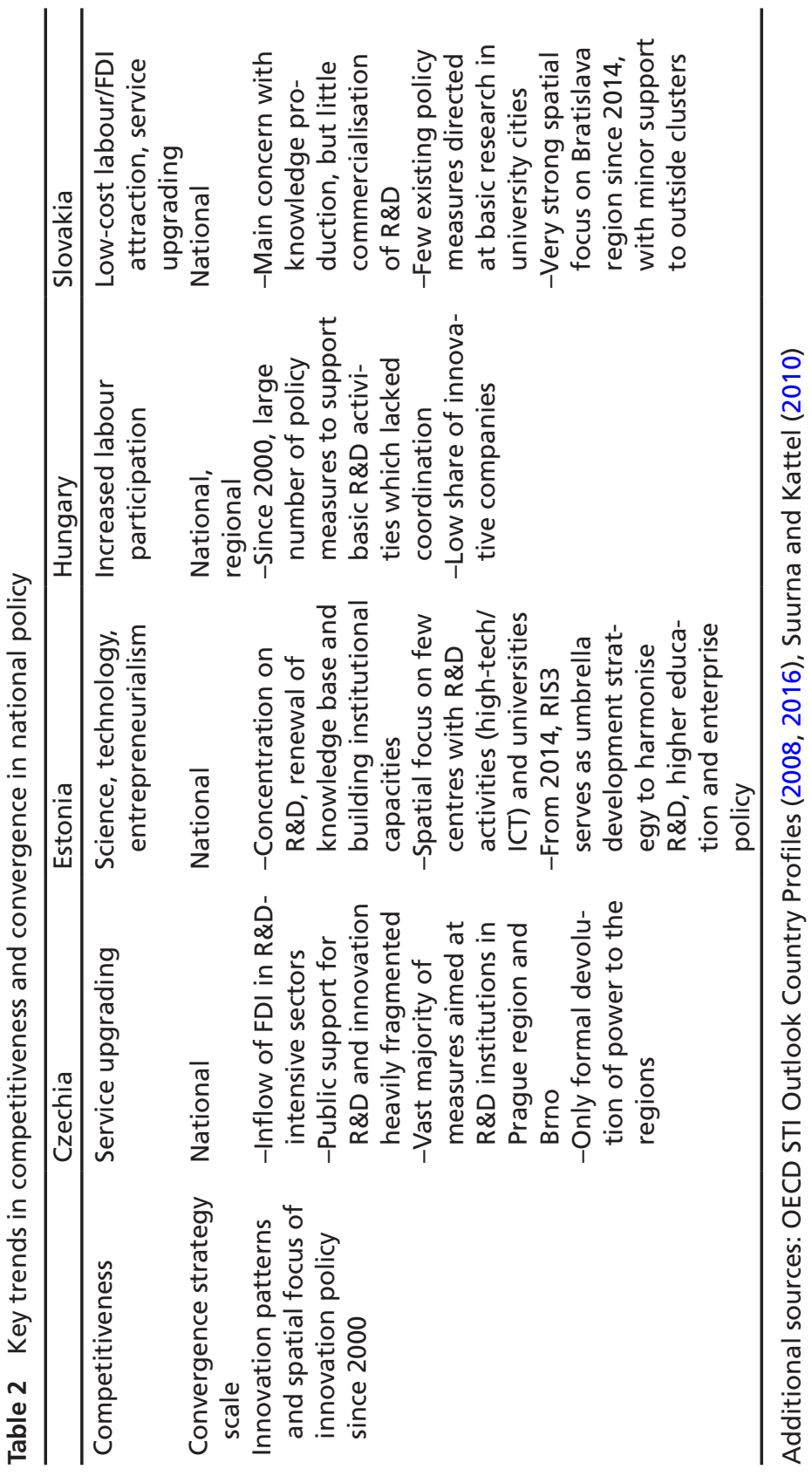


peripheries. Expert interviews indicated that national convergence strategies have been favoured in Czechia, Estonia and Slovakia, while the reduction of regional inequalities remains relatively important in Hungary, due to strong historical patterns of polarisation. In Czechia, regional inequalities have been historically low, and were therefore not considered to be a significant problem (Interview, Pardubice, 3 July 2017). Similarly, experts in Estonia and Slovakia indicated that regional inequalities remain a relatively low political priority despite their strength (Interview, Tallinn, 5 May 2016; Interview, Tallinn, 17 May 2016; Interview, Bratislava, 18 January 2016 (2)). In contrast to the others, the reduction of regional inequalities remains relatively important in Hungary, due to strong historical patterns of polarisation. The reduction of regional inequalities has accordingly been a core development priority since the late socialist period (Interview, Pécs, 25 November 2015 (1)), and remains a prominent objective within the current highly centralised system (Interview, Budapest, 24 November 2015 (1)). Nevertheless, the shift to the competitiveness agenda has enabled a stronger case for investment in the capital regions in all four countries due to the promotion of agglomeration and spillover effects, on the one hand, and centralisation of policy programming and implementation, on the other.

\subsection{Cohesion Policy and the Capacity for Innovation}

In terms of Innovation Policy, there were no targeted strategies at the national level in CEE prior to EU accession, although there were sustained R\&D efforts prompted by the Soviet Union during socialist times (Interview, Bratislava, 18 January 2016 (1)). The political and economic integration of CEE countries in the 1990s was led by influential economic, political and financial institutions such as the EU, the World Bank and the IMF (see, for example, The World Bank 1992, 1995), which national political elites in CEE willingly accepted (Kattel and Primi 2010; Interview, Tallinn, 28 February 2017). European programmes such as PHARE focused on building democratic governance institutions and constructing the internal market during the transition 
and pre-accession periods. But they were also instrumental in building the regions and piloting regional Operational Programmes (Bruszt 2008), thus tying into 'Europe of the Regions' ideals of regionalisation and Cohesion Policy mechanisms.

Economic policies inspired by international organisations marginalised the idea of formulating targeted innovation policies, instead aiming at other priorities such as privatisation and attracting foreign direct investment. The political emphasis focused on macroeconomic stability and restructuring processes, such that the erosion of the socialist $R \& D$ system and opening to market demand were key forces in reforming the innovation system (Suurna and Kattel 2010). In the post-accession period, the EU impact on innovation policies in all four countries has been tremendous. In countries such as Slovakia, for instance, EU accession brought innovation policy onto the agenda for the first time. National strategies were formulated closely along the normative position of EU policy, and remained very short-term in their outlook (Interview, Bratislava, 2 February 2017). Some authors also point out that the adherence to more general EU conditionalities, such as the principle of fiscal and monetary discipline endorsed by those institutions, has limited the array of policy options available to CEE countries (e.g. Faragó and Varró 2016).

Innovation Policy was introduced in CEE countries in tandem with the 'Lisbonisation' of Cohesion Policy, and they were thus already intertwined during the first two programming periods of CEE participation, 2004-2006 and 2007-2013. In these periods, the new member states designed their regional policy programmes in close consultation with Brussels, producing formulaic and homogenised national development strategies to form the basis of similarly formulaic OPs. Following a different logic of regional development from pre-accession instruments (e.g. PHARE, ISPA), arguably little policy learning from the pre-accession period was transferable. The complicated process orientation of the new Cohesion Policy (through Structural and Cohesion Funds), in practice, shifted the priority towards spending eligible funds rather than tackling real regional problems on the ground (Interview, Pardubice, 3 July 2017), highlighting lacking capacities in the less 
developed regions to implement innovative, growth-inducing projects. Poor absorption of available funds became a serious threat to Cohesion Policy in CEE, and project selection moved towards favouring ease of implementation over project merit in achieving policy objectives (European Commission 2013). Moreover, project writing for the peripheral regions was taken up by core-based external experts including NGOs in Czechia and private consultants in Hungary (Interview, Prague, 21 November 2016; Interview, Békéscsaba, 26 January 2016). Scholars have found that a significant 'project class' developed in both countries (Kovách and Kučerová 2006), whereas new elites with the ability to cross public and private sectors due to personalism and multifunctionalism also emerged in Estonia (Aunapuu-Lents 2013). In Slovakia, the centralisation of policy-making at the national level led to the concentration of high-level civil servants and experts in the field of innovation policy in the capital city, Bratislava. The same goes for expertise on EU-related issues (Interview, Nitra, 28 September 2016). Also, the impact of the Structural Funds following EU accession reinforced the problems in Estonia and other CEE countries that emerged during the pre-accession period, such as low coordination and cooperation between administrations and weak administrative capacity (Interview, Tallinn, 28 February 2017).

In the current programming period for 2014-2020, even closer policy coordination with Europe 2020 emphasised innovation and competitiveness following periods of poor Cohesion Policy performance. Nevertheless, CEE countries brought experience and lessons learnt from the previous periods. Reforms to Cohesion Policy favoured the centralisation of Managing Authorities and a reduction of Operational Programmes (especially Regional Operational Programmes) across the board. This potentially granted further central state controls over project selection and implementation, while competitiveness (i.e. innovation) programmes extended Cohesion Policy to all regions in Europe, including urban and highly developed areas. In the case of Slovakia, a targeted and long-term innovation strategy only started to emerge in this period, when the EU made it a requirement for member states to draw up Smart Specialisation strategies to access Structural Funds. 
Experts tend to question the role of cohesion in the current period, and concede that the emphasis on competitiveness promoted by European policy is disadvantageous to peripheries (Interview, Pécs, 25 November 2017 (2); Interview, Pardubice, 3 July 2017). In CEE countries such as Hungary, where Cohesion Policy has traditionally been used to provide basic infrastructure in severely underdeveloped areas, there is a lack of suitable projects in the peripheries for competitivenessbased economic development (Interview, Budapest, 24 November 2017 (2); Interview, Pécs, 25 November 2017 (1)). Moreover, in Estonia, government officials perceive a lack of capable partners in the peripheries, and the blind project selection process tends to favour firms in the core (Interview, Tallinn, 17 May 2016). Therefore, in some cases, an innovation or competitiveness-based strategy can run counter to the objectives of cohesion.

The different national approaches highlighted by experts in CEE countries nevertheless share a common perspective reflecting their peripherality in the EU, whether it is expressed in terms of geographical proximity, relation to the economic core, or influence on policy-making. Moreover, the dependence of certain CEE countries on their own cores (i.e. highly developed capital regions) as centres of innovation and drivers of national development, such is the case in the countries studied herein, bring the relevance of Cohesion and Innovation Policy into question. It is reasonable to predict that in increasingly centralised national settings such as in CEE, an Innovation Policy that benefits the capitals may eventually be seen as more politically palatable than the Cohesion Policy, which faces difficulties in implementation and a history of perceived poor performance.

\section{Conclusions}

This chapter examined the apparent convergence of Cohesion and Innovation Policy as it particularly pertains to CEE countries, wherein these supranational policies are main drivers of growth affecting spatial patterns of development. The theoretical contradictions between these two policy areas as well as the abilities for member 
states to derive their own national responses to promote growth while addressing strong regional polarisation suggests the need to carefully rethink the interaction of these policies for the future EU programming period.

The analysis has shown that Cohesion Policy, increasingly intertwined with Innovation Policy, has been used as a tool for economic growth in CEE countries with little relative regard for regional inequalities. Nevertheless, the traditional aims of Cohesion Policy to support backward regions are still seen to be important for stabilising socio-economic processes related to regional growth and decline, as national policy experts have been shown to recognise incompatibilities between cohesion aims and growth-through-innovation strategies. Some recommendations regarding the policy convergence are formulated below.

While innovation can be a strategy for economic growth, thus contributing to cohesion, it is crucial to avoid essentialising Cohesion Policy in such terms. The relationship between Cohesion Policy and Innovation Policy must be more clearly understood. As Cohesion Policy underwent the neoliberalising 'Lisbonisation' process, reorienting it to competitiveness and growth, the principle of growth-through-innovation has risen as the EU's economic strategy. On a national level, some countries such as Estonia were early implementers of this principle compared to others such as Slovakia, where it was not specifically implemented until the current programming period. Continuing these developments, Innovation Policy has the potential to co-opt Cohesion Policy as a tool for economic development, thereby constraining it, and jeopardising its legitimacy as a moderating force across the EU.

The shift in Cohesion Policy towards narrowly conceptualised post-Lisbon objectives such as 'innovation' run the risk of favouring trendy over banal policy areas. The notion that growth-throughinnovation is an appropriate strategy for all regions must be challenged, and regions with poor innovation capacity should not be excluded from interventions. As Cohesion Policy has been extended to all of Europe's regions, and the divisions between the more developed, transition and less developed regions blur, it may be useful to reconsider 
the relevant institutional arrangements embodied in territorial and administrative hierarchies. Pre-Lisbon (and pre-accession) institutional arrangements and policies focused on democratic legitimacy and power sharing, such as through the Europe of the Regions strategy and pre-accession instruments to CEE countries, have renewed relevance and could be revisited as a model for Cohesion Policy. Strong regions are a necessary condition for successful partnerships with central governments to implement Cohesion Policy programmes, whether they should be focused on economic development, innovation or otherwise, but the centralisation of policy and programming has weakened legitimacy and capacities. Thus, preserving the integrity of Cohesion Policy should remain top of mind when pursuing a growth-based innovation strategy.

Where could the development of Cohesion and Innovation Policies lead? Rather than equating one policy with the other, as some might be apt to do for all practical purposes, it may be useful to dissect the economic domain from Cohesion Policy altogether. If Innovation Policy were to stand on its own as the EU's economic policy, Cohesion Policy could refocus on the traditional domains of infrastructure or social investment in underdeveloped regions. Alternatively, Innovation Policy could be adopted as the economic strategy of Cohesion Policy with equal standing alongside social and environmental strategies. Either way, transparency between the two policy domains would improve understanding of the impacts of different policy interventions, more directly responding to the needs of countries and regions of different levels of economic and social development. In a time of uncertainty surrounding Cohesion Policy and the very meaning of cohesion, efforts must be made to demonstrate its relevance in the (post-) neoliberal era. Clearly distinguishing between economic and other aims of Cohesion and Innovation Policies may serve this purpose. 


\subsection{Four Key Points}

- Cohesion Policy has shifted in its overall aim from reflecting ideals of regionalisation and integration associated with the 'Europe of the Regions' strategy, to competitiveness and growth associated with the Lisbon Agenda, and to innovation associated with Europe 2020.

- In CEE countries, these shifts coincided, firstly, with transition and EU accession, democratic and institutional capacity-building, and extreme underdevelopment of peripheral regions, and secondly with 'catching up', crisis-induced polarisation, political centralisation and regional competition.

- Recently, the EU's Smart Specialisation approach has accelerated the 'Europeanisation' of national innovation policies, especially in CEE countries due to their brief history in formulating innovation policies. While the EU's influence has been beneficial in providing policy advice and best practices, it also demands adherence to predefined principles (i.e. 'ex-ante conditionalities'), thereby limiting the member states' room for manoeuvre when choosing policy options.

- Cohesion Policy has come to be the EU's main investment strategy whose distinct competitiveness focus, while having contributed to growth and increased convergence at the member state level, is likely to sustain current polarisation processes among EU regions. As Cohesion Policy is above all trying to keep the EU economically competitive at the global scale, it is moving away from its traditional goal of promoting spatial cohesion by supporting development at the regional and local levels.

\section{Appendix}

See Tables 3 and 4. 


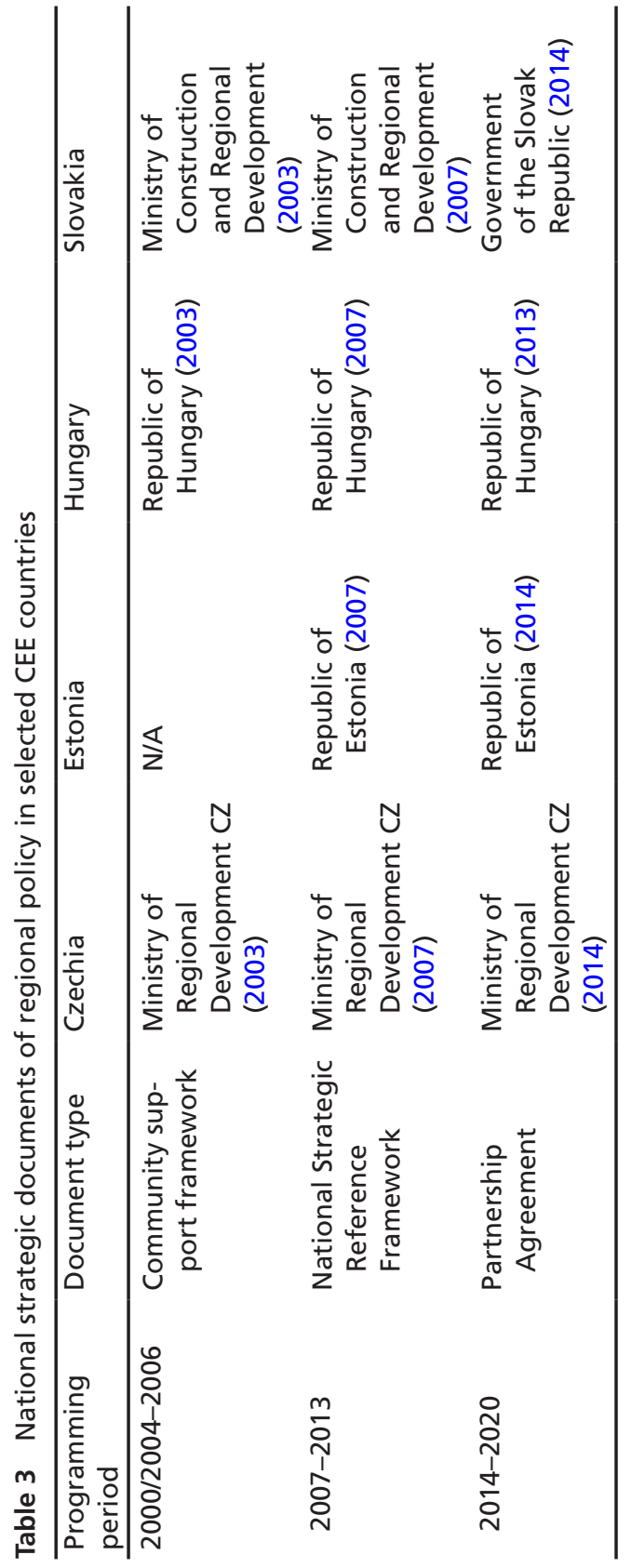


Table 4 Interview participants

\begin{tabular}{|c|c|c|c|}
\hline Interview & Location & Date & Position \\
\hline Interview & Budapest, HU & 24 November 2015 (1) & $\begin{array}{l}\text { Civil servant, Ministry } \\
\text { for National } \\
\text { Economy }\end{array}$ \\
\hline Interview & Budapest, HU & 24 November 2015 (2) & $\begin{array}{l}\text { Public servant, } \\
\text { Ministry for National } \\
\text { Economy }\end{array}$ \\
\hline Interview & Pécs, HU & 25 November 2015 (1) & $\begin{array}{l}\text { Academic, Centre } \\
\text { for Economic and } \\
\text { Regional Studies } \\
\text { of the Hungarian } \\
\text { Academy of Sciences } \\
\text { (CERS HAS) }\end{array}$ \\
\hline Interview & Pécs, HU & 25 November 2015 (2) & Academic, CERS HAS \\
\hline Interview & Municipality, HU & 13 January 2016 & Mayor \\
\hline Interview & Bratislava, SK & 18 January 2016 (1) & $\begin{array}{l}\text { Director, Innovation } \\
\text { Support Agency }\end{array}$ \\
\hline Interview & Bratislava, SK & 18 January 2016 (2) & $\begin{array}{l}\text { Public servant, } \\
\text { Ministry of Economy }\end{array}$ \\
\hline Interview & Békéscsaba, HU & 26 January 2016 & Academic, CERS HAS \\
\hline Interview & Tallinn, EE & 5 May 2016 & Academic, University \\
\hline Interview & Tallinn, EE & 17 May 2016 & $\begin{array}{l}\text { Public servant, } \\
\text { Ministry of Finance }\end{array}$ \\
\hline Interview & Nitra, SK & 28 September 2016 & Director, NGO \\
\hline Interview & Prague, CZ & 21 November 2016 & Academic \\
\hline Interview & Bratislava, SK & 2 February 2017 & $\begin{array}{l}\text { Director NGO; public } \\
\text { servant of Liaison } \\
\text { Office in Brussels }\end{array}$ \\
\hline erview & Tallinn, EE & 28 February 2017 & Academic, University \\
\hline Interview & Pardubice, CZ & 3 July 2017 & Academic, University \\
\hline
\end{tabular}

\section{References}

Aunapuu-Lents, Vivia. 2013. "Rural Policy in Estonia: The Leader Approach and the Concentration of Power." Halduskultuur-Administrative Culture 14 (1): $125-44$.

Avdikos, Vasilis, and Anastassios Chardas. 2016. "European Union Cohesion Policy Post 2014: More (Place-Based and Conditional) Growth-Less Redistribution and Cohesion.” Territory, Politics, Governance 4 (1): 97-117. https://doi.org/10.1080/21622671.2014.992460. 
Bachtler, John, and Irene McMaster. 2008. "EU Cohesion Policy and the Role of the Regions: Investigating the Influence of Structural Funds in the New Member States." Environment and Planning C: Government and Policy 26 (2): 398-427. https://doi.org/10.1068/c0662.

Barca, Fabrizio. 2009. "An Agenda for a Reformed Cohesion Policy: A PlaceBased Approach to Meeting European Union Challenges and Expectations." Independent Report Prepared at the Request of the European Commissioner for Regional Policy, Danuta Hübner. Brussels: European Commission. http://www.europarl.europa.eu/meetdocs/2009_2014/documents/regi/dv/ barca_report_/barca_report_en.pdf.

Bohle, Dorothee, and Béla Greskovits. 2007. "Neoliberalism, Embedded Neoliberalism and Neocorporatism: Towards Transnational Capitalism in Central-Eastern Europe." West European Politics 30 (3): 443-66. https://doi. org/10.1080/01402380701276287.

Borrás, Susana. 2003. The Innovation Policy of the European Union: From Government to Governance. Cheltenham: Edward Elgar.

Borrás-Alomar, Susana, Thomas Christiansen, and Andrés Rodríguez-Pose. 1994. "Towards a 'Europe of the Regions'? Visions and Reality from a Critical Perspective." Regional Politics and Policy 4 (2): 1-27. https://doi. org/10.1080/13597569408420896.

Bruszt, László. 2008. "Multi-level Governance-The Eastern Versions: Emerging Patterns of Regional Developmental Governance in the New Member States." Regional and Federal Studies 18 (5): 607-27. https://doi. org/10.1080/13597560802351622.

Committee of the Regions. 2009. "The White Paper on Multi-Level Governance.” Brussels: Committee of the Regions. http://cor.europa.eu/en/ activities/governance/Documents/mlg-white-paper/0387_inside-en-last.pdf. ESPON. 2014. "Territories Finding a New Momentum: Evidence for Policy Development, Growth and Investment. Third ESPON Synthesis Report. ESPON Results by July 2014.” Luxembourg: ESPON 2013 Programme. http://www.espon.eu/export/sites/default/Documents/Publications/ SynthesisReport/ThirdSeptember2014/ESPON_SYNTHESIS_ REPORT_3.pdf.

European Commission. 1994. "Regional Technology Plan Guide Book.” DG XVI/DG XIII. Brussels: European Commission.

European Commission. 1997. "Agenda 2000. For a Stronger and Wider Union.” Supplement 5/97, Bulletin of the European Union. Luxembourg: Office for Official Publications of the European Communities. https:// 
ec.europa.eu/agriculture/sites/agriculture/files/cap-history/agenda-2000/ com97-2000_en.pdf.

European Commission. 1999. "ESDP_European Spatial Development Perspective: Towards Balanced Sustainable Development of the Territory of the European Union.” Luxembourg: Office for Official Publications of the European Communities. http://ec.europa.eu/regional_policy/sources/ docoffic/official/reports/pdf/sum_en.pdf.

European Commission. 2004. "Facing the Challenge. The Lisbon Strategy for Growth and Employment." Report from the High Level Group, Chaired by Wim Kok. Luxembourg: Office for Official Publications of the European Communities. https://ec.europa.eu/research/evaluations/pdf/archive/fp6evidence-base/evaluation_studies_and_reports/evaluation_studies_and_ reports_2004/the_lisbon_strategy_for_growth_and_employment_report_ from_the_high_level_group.pdf.

European Commission. 2005. "Working Together for Growth and Jobs. A New Start for the Lisbon Strategy. Communication from President Barroso in Agreement with Vice-President Verheugen." Communication to the Spring European Council. SEC (2005) 192, SEC (2005) 193. Brussels: Commission of the European Communities. https://eur-lex.europa.eu/ legal-content/EN/TXT/PDF/?uri=CELEX:52005DC0024\&from=EN.

European Commission. 2006. "Regions for Economic Change." Communication from the Commission. COM (2006) 675 Final. Brussels: Commission of the European Communities. http://eur-lex.europa.eu/ legal-content/EN/TXT/PDF/?uri=CELEX:52006DC0675\&from=EN.

European Commission. 2010. "Europe 2020: A Strategy for Smart, Sustainable and Inclusive Growth." Communication from the Commission. COM (2010) 2020. Brussels: European Commission. http://ec.europa.eu/ eu2020/pdf/COMPLET\%20EN\%20BARROSO\%20\%20\%20007\%20 -\%20Europe\%202020\%20-\%20EN\%20version.pdf.

European Commission. 2013. "Expert Evaluation Network on the Performance of Cohesion Policy 2007-2013. Synthesis of National Reports 2013.” A Report to the European Commission, Directorate-General for Regional and Urban Policy. Brussels: European Union. http://ec.europa. eu/regional_policy/sources/docgener/evaluation/pdf/eval2007/2013_een_ task2_synthesis_final.pdf.

European Commission. 2014. "Investment for Jobs and Growth. Promoting Development and Good Governance in EU Regions and Cities. Sixth Report on Economic, Social and Territorial Cohesion.” Luxembourg: 
Publications Office of the European Union. http://ec.europa.eu/ regional_policy/sources/docoffic/official/reports/cohesion6/6cr_en.pdf.

European Commission. 2017. "My Region, My Europe, Our Future. Seventh Report on Economic, Social and Territorial Cohesion." Luxembourg: Publications Office of the European Union. http://ec.europa.eu/regional_ policy/sources/docoffic/official/reports/cohesion7/7cr.pdf.

Faragó, László, and Krisztina Varró. 2016. "Shifts in EU Cohesion Policy and Processes of Peripheralization: A View from Central Eastern Europe." European Spatial Research and Policy 23 (1): 5-19. https://doi.org/10.1515/ esrp-2016-0001.

Farole, Thomas, Andrés Rodríguez-Pose, and Michael Storper. 2011. "Cohesion Policy in the European Union: Growth, Geography, Institutions." Journal of Common Market Studies 49 (5): 1089-111. https:// doi.org/10.1111/j.1468-5965.2010.02161.x.

Foray, Dominique, Paul A. David, and Bronwyn Hall. 2009. "Smart Specialisation-The Concept.” In Knowledge for Growth: Prospects for Science, Technology and Innovation, Selected Papers from Research Commissioner Janez Potočnik's Expert Group, 20-24. Brussels: European Commission. http://ec.europa.eu/invest-in-research/pdf/download_en/selected_ papers_en.pdf.

Government of the Slovak Republic. 2014. "Partnership Agreement of the Slovak Republic for the Years 2014-2020.” Bratislava: Slovakia.

Hadjimichalis, Costis. 2011. "Uneven Geographical Development and SocioSpatial Justice and Solidarity: European Regions After the 2009 Financial Crisis." European Urban and Regional Studies 18 (3): 254-74. https://doi. org/10.1177/0969776411404873.

Hadjimichalis, Costis, and Ray Hudson. 2014. "Contemporary Crisis Across Europe and the Crisis of Regional Development Theories." Regional Studies 48 (1): 208-18. https://doi.org/10.1080/00343404.2013.834044.

Hansen, Teis, and Lars Winther. 2011. "Innovation, Regional Development and Relations Between High- and Low-Tech Industries." European Urban and Regional Studies 18 (3): 321-39. https://doi. org/10.1177/0969776411403990.

Hudson, Ray. 2003. "European Integration and New Forms of Uneven Development: But Not the End of Territorially Distinctive Capitalisms in Europe." European Urban and Regional Studies 10 (1): 49-67. https://doi. org/10.1177/a032539. 
Kalman, Judit, and Marek Tiits. 2014. "Coordinated Policies and Cohesion Policies: Their Relationship and Impact on the Member States." GRINCOH Working Paper Series, Paper 7.04. http://www.grincoh.eu/ media/serie_7_institutional_convergence/grincoh_wp7.04_kalman_tiits. pdf.

Kattel, Rainer, and Annalisa Primi. 2010. "The Periphery Paradox in Innovation Policy: Latin America and Eastern Europe Compared. Some Reflections on Why It Is Not Enough to Say that Innovation Matters for Development." Working Papers in Technology Governance and Economic Dynamics 29, 44 Pages. http://hum.ttu.ee/wp/paper29.pdf.

Kovách, Imre, and Eva Kučerová. 2006. "The Project Class in Central Europe: The Czech and Hungarian Cases." Sociologia Ruralis 46 (1): 3-21. https:// doi.org/10.1111/j.1467-9523.2006.00403.x.

KPMG. 2016. "EU Funds in Central and Eastern Europe. Progress Report 2007-2015.” KPMG Central and Eastern Europe. https://assets.kpmg. $\mathrm{com} /$ content/dam/kpmg/pdf/2016/06/EU-Funds-in-Central-and-EasternEurope.pdf.

Kühn, Manfred. 2015. "Peripheralization: Theoretical Concepts Explaining Socio-Spatial Inequalities." European Planning Studies 23 (2): 367-78. https://doi.org/10.1080/09654313.2013.862518.

Kuus, Merje. 2011. "Whose Regional Expertise? Political Geographies of Knowledge in the European Union." European Urban and Regional Studies 18 (3): 275-88. https://doi.org/10.1177/0969776411406034.

Lagendijk, Arnoud. 2011. "Regional Innovation Policy Between Theory and Practice." In Handbook of Regional Innovation and Growth, edited by Philip Cooke, Bjørn Asheim, Ron Boschma, Ron Martin, Dafna Schwartz, and Franz Tödtling, 598-608. Cheltenham: Edward Elgar.

Lagendijk, Arnoud, and Krisztina Varró. 2013. "European Innovation Policies from RIS to Smart Specialization: A Policy Assemblage Perspective." In The Innovation Union in Europe: A Socio-Economic Perspective on EU Integration, edited by Elias G. Carayannis and George M. Korres, 99-119. Cheltenham: Edward Elgar.

Lang, Thilo, Sebastian Henn, Wladimir Sgibnev, and Kornelia Ehrlich, eds. 2015. Understanding Geographies of Polarization and Peripheralization. Perspectives from Central and Eastern Europe and Beyond. New Geographies of Europe. Basingstoke: Palgrave Macmillan. 
Loewen, Bradley. 2015. "Contextualising Regional Policy for Territorial Cohesion in Central and Eastern Europe." Hungarian Geographical Bulletin 64 (3): 205-17. https://doi.org/10.15201/hungeobull.64.3.4.

Lois González, Rubén Camillo. 2013. "The "Europe 2020 Strategy" as a Vision to Emerge from the Crisis: An Overall Interpretation." In European Regions in the Strategy to Emerge from the Crisis: The Territorial Dimension of the "Europe 2020", edited by Lois González Rubén Camillo and Valerià Paül I Carril, 17-27. Santiago de Compostela: Servizo de Publicacións da Universidade de Santiago de Compostela.

Loughlin, John. 1996. "Europe of the Regions' and the Federalization of Europe." Publius 26 (4): 141-62. http://www.jstor.org/stable/3330775.

McCann, Philip, and Raquel Ortega-Argilés. 2013. "Smart Specialization, Regional Growth and Applications to European Union Cohesion Policy." Regional Studies 49 (8): 1291-302. https://doi.org/10.1080/00343404.201 3.799769 .

Mendez, Carlos. 2011. "The Lisbonization of EU Cohesion Policy: A Successful Case of Experimentalist Governance?” European Planning Studies 19 (3): 519-37. https://doi.org/10.1080/09654313.2011.548368.

Mendez, Carlos. 2012. "Clouds, Clocks and Policy Dynamics: A Path-(Inter) Dependent Analysis of EU Cohesion Policy." Policy \& Politics 40 (2): 15370. https://doi.org/10.1332/030557311X560680.

Ministry of Construction and Regional Development SK. 2003. "Summary of the Community Support Framework of Slovakia 2004-2006.” Bratislava: Slovak Republic.

Ministry of Construction and Regional Development SK. 2007. "National Strategic Reference Framework of Slovakia 2007-2013.” Bratislava: Slovakia.

Ministry of Regional Development CZ. 2003. "Community Support Framework: Czech Republic 2004-2006.” CCI: 2003CZ161CC001. Prague: Czech Republic.

Ministry of Regional Development CZ. 2007. "National Strategic Reference Framework of the Czech Republic 2007-2013.” Prague: Czech Republic.

Ministry of Regional Development CZ. 2014. "Partnership Agreement for the Programming Period 2014-2020: Czech Republic.” Prague: Czech Republic.

Nosek, Štěpán. 2017. "Territorial Cohesion Storylines in 2014-2020 Cohesion Policy.” European Planning Studies 25 (12): 2157-74. https://doi.org/10.10 80/09654313.2017.1349079. 
OECD. 2008. "STI Outlook Country Profiles: Czech Republic/Estonia/ Hungary.” Paris: OECD. https://innovationpolicyplatform.org.

OECD. 2016. "STI Outlook Country Profiles: Czech Republic/Estonia/ Hungary.” Paris: OECD. https://innovationpolicyplatform.org.

Republic of Estonia. 2007. "Estonian National Strategic Reference Framework 2007-2013.” Tallinn: Republic of Estonia.

Republic of Estonia. 2014. "Partnership Agreement for the Use of European Structural and Investment Funds 2014-2020." 2014EE16M8PA001. Tallinn: Republic of Estonia.

Republic of Hungary. 2003. "Community Support Framework 20042006: Republic of Hungary: Objective 1 of the Structural Funds." CCI: 2003HU161CC001. Budapest: Republic of Hungary.

Republic of Hungary. 2007. "The New Hungary Development Plan: National Strategic Reference Framework of Hungary 2007-2013: Employment and Growth.” Budapest: Republic of Hungary.

Republic of Hungary. 2013. "Hungarian Partnership Agreement, for the 2014-2020 Programming Period.” Budapest: Republic of Hungary.

Sapir, André, Philippe Aghion, Giuseppe Bertola, Martin Hellwig, Jean PisaniFerry, Dariusz Rosati, José Viñals, Helen Wallace, Marco Buti, Mario Nava, and Peter M. Smith. 2003. An Agenda for a Growing Europe: The Sapir Report. Oxford: Oxford University Press.

Soete, Luc. 2009. "The Role of Community Research Policy in the Knowledge-Based Economy." Expert Group Report. Brussels: European Commission, Directorate-General for Research.

Stark, David, and László Bruszt. 1998. Postsocialist Pathways: Transforming Politics and Property in East Central Europe. Cambridge: Cambridge University Press.

Suurna, Margit, and Rainer Kattel. 2010. "Europeanization of Innovation Policy in Central and Eastern Europe." Science and Public Policy 37 (9): 646-64. https://doi.org/10.3152/030234210X12778118264459.

The World Bank. 1992. "Hungary: Reform and Decentralization of the Public Sector: Main Report.” Report No. 10061-HU. Washington: The World Bank.

The World Bank. 1995. "Estonia: Financing Local Governments." Report No. 14925-EE. Washington: The World Bank. 
Open Access This chapter is licensed under the terms of the Creative Commons Attribution 4.0 International License (http://creativecommons. org/licenses/by/4.0/), which permits use, sharing, adaptation, distribution and reproduction in any medium or format, as long as you give appropriate credit to the original author(s) and the source, provide a link to the Creative Commons license and indicate if changes were made.

The images or other third party material in this chapter are included in the chapter's Creative Commons license, unless indicated otherwise in a credit line to the material. If material is not included in the chapter's Creative Commons license and your intended use is not permitted by statutory regulation or exceeds the permitted use, you will need to obtain permission directly from the copyright holder. 


\section{Divergent Paths to Cohesion: The (Unintended) Consequences of a Place-Based Cohesion Policy}

\section{Stefan Telle, Martin Špaček and Daniela Crăciun}

\section{Cohesion Policy to Which End?}

Judging by its name, the objective of the European Union's (EU) Cohesion Policy (CP) seems clear: to promote cohesion in the EU. But what do we mean when we talk about cohesion? Answering this question is complicated for two interrelated reasons.

First, the main legal basis for $\mathrm{CP}$-Article 174 of the Treaty on the Functioning of the European Union-provides an exceedingly broad and vague definition of "economic, social and territorial cohesion". Rather than contributing to a better understanding of the concept, this

S. Telle $(\bowtie) \cdot D$. Crăciun

Central European University, Budapest, Hungary

M. Špaček

Comenius University, Bratislava, Slovakia

(C) The Author(s) 2019

T. Lang and F. Görmar (eds.), Regional and Local Development 
formulation points to the various domains it shall apply to. Moreover, it does not clarify at which level cohesion shall be promoted. From the perspective of this chapter, this scale-insensitivity is particularly problematic as shown by the polarising dynamic of simultaneous improvements of economic cohesion at the national level (Forgó and Jevčák 2015) and deterioration at the regional level within member states (Lang et al. 2015; Medve-Bálint 2014).

Second, as illustrated by the incessant debates surrounding it, the evolving political context of European integration continuously reshuffles the form and function of CP. To begin with, Manzella and Mendez (2009) suggest that CP was initially a side-payment for securing the support of the Mediterranean member states (MS) for further market integration. Subsequently, the eastern enlargements raised concerns as to whether a "Europe of Regions" actually provided a suitable framework for the effective and accountable implementation of the policy (cf. Bruszt 2008; Leonardi 2005; Molle 2007).

Enlargement also raised the question of whether CP was promoting an equality-oriented "Social Europe" or a neoliberal "Competitive Europe" (cf. Faludi 2010; Waterhout 2008). On the one hand, the influential Agenda for a Reformed Cohesion Policy (Barca 2009) proposed a set of liberal reforms, such as more efficient governance, a concentration of funds on core priorities, and a place-based approach to regional development. On the other hand, critics claim that the "Lisbonisation" of CP involved trading "more (place-based and conditional) growth" for "less redistribution and cohesion" (Avdikos and Chardas 2016).

The two observations are interrelated. In terms of Sartori's (1970) typology of concept misformation, the first observation points to conceptual stretching. This problematic practice leads to "indefiniteness and elusiveness" because "the more we climb toward high-flown universals, the more tenuous the link with the empirical evidence" (p. 57). Consequently, the second observation illustrates that the lack of conceptual clarity surrounding cohesion lends itself to diverging interpretations about CP's objectives, incites continuous debate, and limits the possibility of evaluating the policy's actual achievements. 
The present chapter addresses this issue. Section 2 suggests that the continuous reshaping of $\mathrm{CP}$ can be understood in terms of experimentalist governance theory. Section 3 introduces computer-assisted text analysis (CATA) as a method to quantify and clarify what we mean when we talk about cohesion in CP. Section 4 presents the findings. First, it compares the Lisbon Agenda and the Europe 2020 strategy to establish a baseline for changes in policy objectives. Second, it finds a corresponding tendency in regional-level cross-border cooperation programmes. However, an in-depth analysis reveals a divergence of programme objectives between old and new member states. These findings suggest that a more place-based CP may lead to different paths to cohesion. Section 5 uses data from roughly one hundred in-depth interviews to provide some tentative explanations for this regional-level variation. The last section concludes with a summary of the argument and policy implications.

\section{Implications of Concept Misformation for Policy Change}

The last section argued that the evolving political context of European integration drives continuous policy change. This section proposes that this is the case because the open-ended nature of integration builds the requirement for continuous adaptation into the process of EU policy-making. While this characteristic often leads to the problems described above, the theory of experimentalist governance emphasises the possibility of a more benign solution (De Búrca et al. 2014; Sabel and Zeitlin 2008, 2010, 2012; Zeitlin 2015).

Experimentalist governance suggests that a virtuous feedback loop of shared policy design, place-based implementation, and results pooling can reduce the gap between policy inclusiveness and policy efficiency. In other words, this approach highlights continuous adaptation as an opportunity to simultaneously boost input and output legitimacy (Scharpf 1997). 
The experimentalist governance process proceeds in four steps. First, higher and lower level units engage in a deliberative policy-design process, at the end of which they agree on a set of general framework objectives as well as on measures to monitor their attainment. Second, lower level units are given sufficient autonomy to engage in experimentation so as to devise creative and place-based solutions to the framework objectives. Third, their progress is closely monitored and all individual experiences are pooled and shared to allow peer review and mutual learning. Fourth, based on these learning processes, institutional structures and framework goals are periodically subjected to scrutiny and recalibrated to reflect changing internal and external conditions. The repetition of this cycle supports the dissemination and connection of distributed knowledge (Newell 2005), the mainstreaming of best practices, and the naming and shaming of underperformers.

CP has several of the characteristics associated with experimentalist governance: it is the essential multi-level policy of the EU (Hooghe 1996), it relies on implementing broad framework objectives (European Parliament and Council 2013) through an increasingly place-based approach (Avdikos and Chardas 2016; Barca 2009), the role of evidence-based learning is becoming more central (Leonardi 2005, Ch. 3; Rodríguez-Pose and Novak 2013; Neacsu and Petzold 2015), and periodic framework revisions have led to wide-ranging changes in policy substance and structure (Bachtler and Mendez 2007; Molle 2007). Moreover, the partnership principle (Demidov 2015) aims at the involvement of national, regional, and local actors in determining programme priorities. Finally, initiatives like ESPON and INTERACT are specifically intended to promote evidence-based decision-making by enabling the gathering and dissemination of knowledge acquired through the implementation of CP (Faludi 2008).

Considering these features, it is understandable that Mendez (2011) asked whether the "Lisbonisation" of CP constitutes "a successful case of experimentalist governance". However, he concluded that "the effects on mutual learning - a core feature of experimentalist governance - have been limited or non-existent and are likely to remain so in the immediate future" (ibid. 534). Importantly, he highlighted 
that the experimentalist dynamics "are handicapped by a lack of clarity and prioritization over EU Cohesion objectives, the lack of political commitment to assessment indicators and targets[,] and uneven performance reporting which focuses too much on financial implementation" (ibid. 534).

In sum, the first two sections of the chapter established concept misformation as an important impediment to the operation of a virtuous feedback loop in CP. To address this issue, CATA provides an easy-touse and reproducible way for disentangling the diverse policy objectives (Craciun 2018) subsumed under cohesion. Therefore, from an experimentalist governance perspective, it has the potential to contribute to more constructive policy debates and to virtuous policy change.

\section{Methodology}

The analysis uses an extended methodological framework to trace changes in policy objectives. It uses a quantitative method (CATA) for gauging changes in policy objectives and a qualitative method (semi-structured interviews) for explaining the variation identified by CATA.

Text analysis represents a scientific method for "making replicative and valid inferences from data to their context" (Krippendorff 1980, 21). CATA is a form of text analysis that uses computers, rather than human coders, to analyse texts. It is used to automatically quantify the existence of certain concepts of interest as well as their embeddedness in the broader institutional context in which they are used (Berg 2001).

The chapter utilises CATA to analyse an original set of documents. The analysis focused on the following key policy concepts: social, employment, cohesion, growth, innovation, competitiveness. The first three concepts broadly reflect the Social Europe discourse, while the last three reflect the Competitive Europe discourse (see Sect. 1). Additionally, the analysis includes development to highlight changes in the meaning of core objectives, as well as priority to indicate the influence of the 2013 CP reform. 
The analysis proceeds in three steps. First, the Lisbon Agenda and Europe 2020 strategy are examined to identify changes in the EU's overarching policy objectives. Second, all Czech and German crossborder operational programmes (OPs) are analysed for the 2007-2013 and 2014-2020 programming periods to see how the macro objectives were translated into regional-level objectives. The principle of multiannual programming ensures that the former period reflects the objectives of the Lisbon Agenda, while the latter period reflects those of the Europe 2020 strategy. The focus on cross-border OPs highlights the significance of regional-level conditions and agency in translating the macro strategies as it allows variation within MS to be studied.

Third, the comparison of Czech and German cross-border OPs works as a natural experiment (cf. Dunning 2017) which allows evaluating the impact of the old/new member state cleavage on the translation process. Accordingly, the chapter divides cross-border OPs into three categories (Table 1): OPs of two old member states [OMS/OMS], OPs of old and new member states [OMS/NMS], and OPs of two new member states [NMS/NMS].

Some caveats need to be mentioned. First, cross-border OPs are not distributed equally across countries and categories. As such, the comparatively lower number of Czech OPs runs the risk of skewing the analysis if one of the OPs is an outlier in terms of the objectives under analysis. Second, not all the OPs fall neatly into the categorisation. On the one hand, Switzerland and Lichtenstein are non-EU countries. On the other hand, Austria and Sweden joined the EU only in 1995. Insofar as the former are concerned, the respective OPs always involve at least two EU MS, whereas insofar as the latter, both countries are commonly considered to be EU-15 countries. Moreover, the PolandDenmark-Germany-Lithuania-Sweden (South Baltic) cross-border OP cannot be included in the analysis for methodological reasons as the programme document was not available in German. Third, the number of German OPs changed between programming periods due to the merger of the Syddanmark-Schleswig K.E.R.N. OP and the Fehmarnbelt Region OP into one Germany-Denmark OP. The analysis includes both cross-border OPs of the 2007-2013 period. 
7 Divergent Paths to Cohesion: The (Unintended) Consequences ...

Table 1 Analysed Czech and German cross-border cooperation OPs

\begin{tabular}{lll}
\hline Category & Germany & Czech Republic \\
\hline [OMS/OMS] & 1) Austria-Germany/Bavaria & \\
& 2) Belgium-Germany-The & \\
Netherlands & \\
& 3) France-Belgium-Germany- & \\
Luxembourg & \\
4) France-Germany- & \\
Switzerland & \\
5) Germany-Austria- & \\
Switzerland-Liechtenstein & \\
& 6) Germany-Denmark & \\
7) Germany-The Netherlands & \\
8) Germany/Bavaria-Czech & 1) Germany/Bavaria-Czech \\
Republic & Republic \\
& 9) Germany/Saxony-Czech & 2) Germany/Saxony-Czech \\
Republic & Republic \\
& 10) Germany/ & \\
Brandenburg-Poland & \\
& 11) Germany/Mecklenburg- & \\
Vorpommern-Brandenburg- & \\
& Poland & \\
12) Poland-Germany/Saxony & \\
& & 4) Czech Republic \\
& & 5) Slovakia-Czech Republic \\
\hline
\end{tabular}

Source Own elaboration

The OPs analysed are shown in italics.

Before using CATA techniques to reduce the complexity of the documents, the texts needed to be pre-processed (Craciun 2018). In practice, this entailed (1) transforming all the documents into .txt format, (2) cleaning the text by removing the parts that are not directly relevant to answering the research question, and (3) taking out stop words (i.e. common words for each language that appear often in the structure of the sentence but do not provide any content).

The web application Voyant Tools (Sinclair and Rockwell 2017) was used to conduct three different kinds of analysis. Trend analysis provides a line graph of word frequencies in different policy documents and 
enables researchers to measure and compare the relative importance of policy objectives. Collocation analysis reveals a network graph of highest frequency terms that appear in proximity with each other within the documents (cf. Lehecka 2015). For the purpose of this chapter, the tool was used to show how the meaning of the policy objectives has changed over time. Finally, correspondence analysis, a type of cluster analysis, was used to illustrate the proximity of individual OPs in terms of the policy objectives (cf. Greenacre 2010). This technique is used to visualise the OMS/NMS divide.

In a final step, the findings obtained via CATA were contrasted with qualitative evidence from six of the analysed OPs (italics in Table 1). As these six OPs cover all three categories ([OMS/OMS], [OMS/NMS], [NMS/NMS]), their analysis allows us to develop explanations for the variation across these categories. The evidence was gathered in 104 semi-structured interviews with representatives of regional and national administrative authorities, OP programme administrations, programme audits, Euroregion representatives, local politicians, and representatives of local non-governmental organisations and municipalities (Table 2). They took place between January 2016 and April 2017 and had an average duration of one hour. The questions focused on the achievements and challenges of cross-border cooperation in the border region, paying attention to issues related to the implementation of the respective INTERREG programmes.

Table 2 Distribution of interviews

\begin{tabular}{llc}
\hline Cross-border cooperation OP & Category & Number of interviews \\
\hline Germany/Bavaria-Austria & [OMS/OMS] & 5 \\
Germany/Bavaria-Czech Republic & [OMS/NMS] & 24 \\
Germany/Saxony-Czech Republic & [OMS/NMS] & 23 \\
Austria-Slovakia & [OMS/NMS] & 20 \\
Austria-Czech Republic & [OMS/NMS] & 16 \\
Slovakia-Czech Republic & [NMS/NMS] & 16 \\
Total & & 104 \\
\hline
\end{tabular}

Source Own elaboration

The OPs analysed are shown in italics 


\section{$4 \quad$ Analysis}

The analysis proceeds in three steps. First, a comparison of the Lisbon Agenda and the Europe 2020 strategy establishes the evolution of the EU's macro objectives. Second, the Czech and German cross-border OPs of the 2007-2013 and 2014-2020 programming period are scrutinised to illustrate how the changes in the macro strategies translate into regional-level OPs. In a third step, the distinction between OPs according to the three categories is used to study the context-dependent implementation of the CP, suggesting OMS and NMS cleavage as an explanatory factor.

\subsection{Macro Strategies: Lisbon Agenda and Europe 2020 Strategy}

The trend analysis of the Lisbon Agenda and the Europe 2020 strategy is based on two key policy framing documents: the Presidency Conclusions of the Lisbon European Council (European Council 2000) and the Communication from the Commission EUROPE 2020. A strategy for smart, sustainable and inclusive growth (European Commission 2010).

The most significant findings include a substantial decrease of the relative word frequency of the concepts social and employment and a simultaneous increase in the frequency of the concepts of growth and innovation (Fig. 1). This development resulted in an alteration of the ranking of the first three most frequent policy concepts from the Lisbon Agenda (social, employment, growth) to the Europe 2020 strategy (growth, social, innovation).

The change in focus may be explained by the macro political context at the time of drafting the two documents. On the one hand, the Lisbon Agenda reflects the expected effects of impending Eastern enlargements, putting questions of social inclusion and employment at centre stage. On the other hand, the Europe 2020 strategy was drafted during the aftermath of the financial and sovereign debt crisis of the late 2000 s and reflects a greater concern with innovation-driven economic growth. 


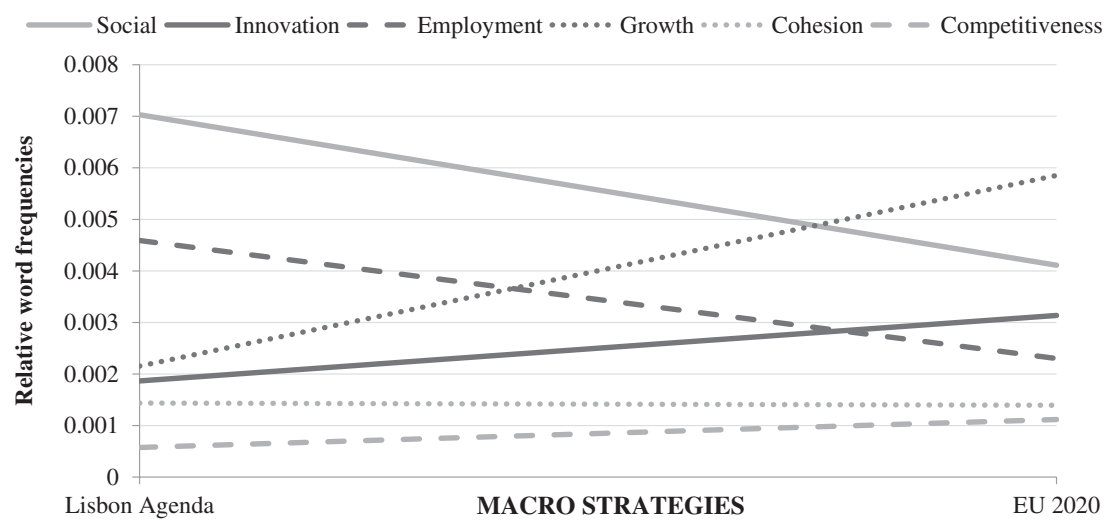

Fig. 1 Trend analysis of policy concepts in the Lisbon Agenda and the Europe 2020 strategy (Source Own elaboration based on Sinclair and Rockwell 2017)

While word frequencies provide a picture of the change in the EU's macro objectives, a more detailed understanding can be gained by conducting collocation analysis to uncover shifts in the meanings attached to these objectives (Fig. 2). At the document level, collocation analysis of the Lisbon Agenda and Europe 2020 strategy confirms the general trend from social towards growth-related issues. Specifically, the term social not only features prominently in the Lisbon Agenda, but is closely related to employment, protection, and exclusion. In contrast, the Europe 2020 strategy is alluding to a variety of terms referring to Europe, ostensibly demonstrating the intention of signalling supranational political unity during the financial crisis. Moreover, the latter document is clearly identified as a strategy for growth, based on goals and measurable targets.

Turning to the concepts development and cohesion, additional significant differences can be observed. While development in the Lisbon Agenda is related to employment and human, the Europe 2020 strategy links development closely to the structural funds as a key delivery framework. The link to research is present in both documents, but the Europe 2020 strategy also highlights innovation. 
7 Divergent Paths to Cohesion: The (Unintended) Consequences ...

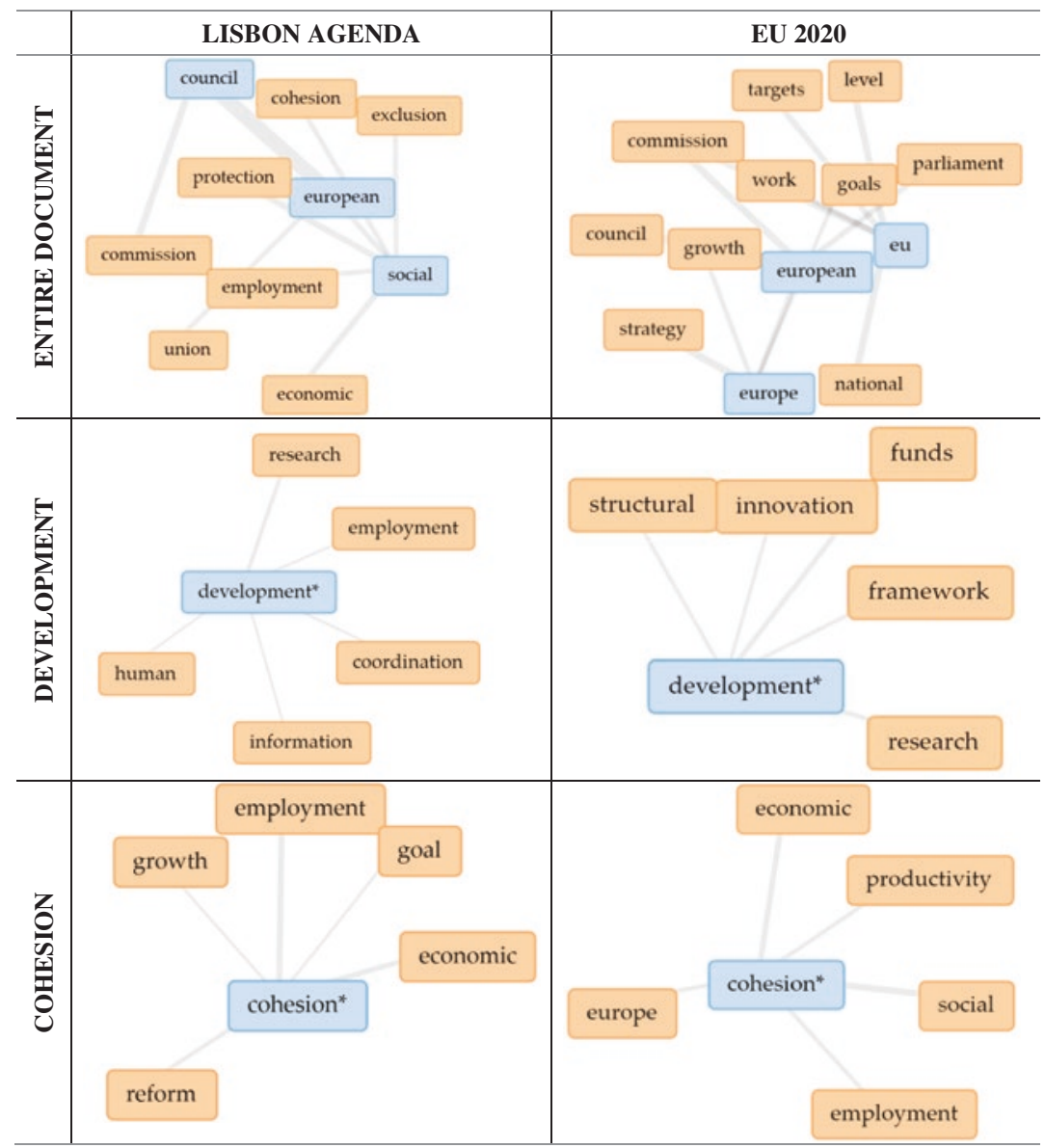

Fig. 2 Collocation analysis of the Lisbon Agenda and the Europe 2020 strategy (Source Own elaboration based on Sinclair and Rockwell 2017)

In both documents, cohesion is related to employment. However, while the Lisbon Agenda refers to employment growth, the Europe 2020 strategy refers to productivity growth. At the same time, the Europe 2020 strategy frames cohesion in both social and economic terms, while in the Lisbon Agenda, it has a purely economic focus. Having established the evolution of the EU's macro objectives, the analysis now turns to regional-level OPs. 


\subsection{Cohesion Policy Implementation: Cross-Border Cooperation Programmes}

To answer the question of how changes in the macro strategies translate into regional-level OPs, trend analysis was conducted for all crossborder OPs with Czech and German participation. This moves the focus of the analysis from the supranational to the regional level and from the strategic to the policy implementation phase.

To this end, the cross-border OPs of the 2007-2013 programming period were aggregated and compared to the OPs of the 2014-2020 programming period for both countries separately. Trend analysis of the German OPs found that development was by far the most frequent concept in both programming periods. Moreover, the introduction of thematic priorities in the 2014-2020 programming period was obvious in the documents. Similar results were obtained in the trend analysis of the Czech OPs, where the term development was the most frequent concept in the programming period 2007-2013. In the following period, it was superseded by the term priority.

- Social — Innovation - - Employment $\cdots \cdots \cdot$ Growth $\cdots \cdots \cdot$ Cohesion - - Competitiveness

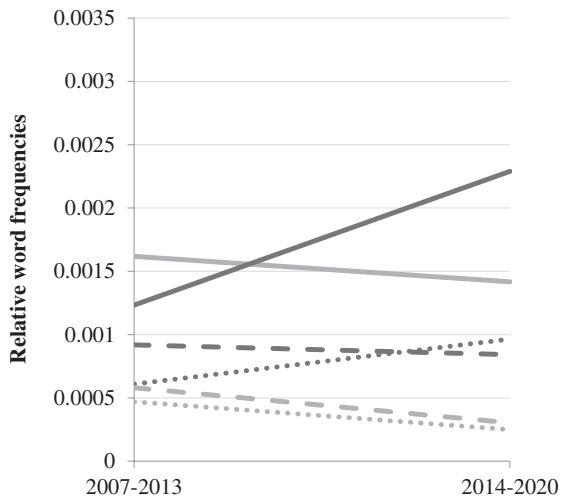

GERMAN OPs

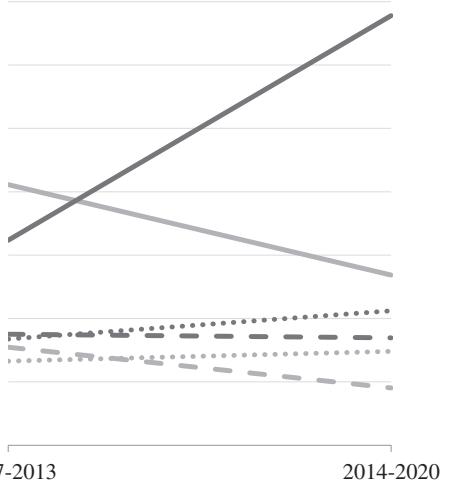

CZECH OPs

Fig. 3 Trend analysis of German and Czech cross-border OPs (2007-2013 vs. 2014-2020) (Source Own elaboration based on Sinclair and Rockwell 2017) 
In fact, these two concepts were so prevalent as to hide the degree of change in the frequency of other core concepts. Hence, they were excluded in the next step of the analysis, both for Germany and for the Czech Republic (Fig. 3). This procedure revealed that the use of the terms innovation and growth has increased significantly, while the terms social, employment, cohesion, and competitiveness have become less frequent or stayed almost unchanged. The lower frequency of the term competitiveness can be interpreted as a shift in terminology towards the more inclusive term of growth. The trend in Czech cross-border OPs broadly corresponds to what has been observed in the German case. It shows a rise in the frequency of the term innovation and (to a lesser extent) growth and a simultaneous decline in the frequency of the term social.

These findings corroborate the argument that the transition from the Lisbon Agenda to the Europe 2020 strategy involved a broad reorientation of the CP towards more "liberal" ideas of welfare creation. The greater focus on thematic priorities, as well as the increased importance of growth, confirm Avdikos and Chardas' (2016) critical assertion that post-2014 CP means "more (place-based and conditional) growth". The next section turns to the differences between the three categories of OPs.

\subsection{Context-Dependent Implementation: The Old/New Member State Cleavage}

The final section analyses whether the OPs show variation along the OMS/NMS cleavage. To this end, the German cross-border OPs were divided into [OMS/OMS] and [NMS/OMS] and the Czech OPs were divided into [OMS/NMS] and [NMS/NMS]. The analysis first compares the categories in each programming period and subsequently highlights the change over time in each category.

In the 2007-2013 programming period, social was the most frequent term both in [OMS/OMS] and in [OMS/NMS] cross-border OPs. However, while [OMS/NMS] OPs were dominated by this term, [OMS/OMS] OPs were more diversified. Here, innovation was as frequent as social and employment and growth also featured centrally. These findings can be interpreted as 
illustrating a preference of the NMS for social cohesion via redistribution and solidarity, while the OMS appear to be influenced by liberal ideas of creating equality through empowerment of the individual.

Importantly, the divide between [OMS/OMS] and [OMS/NMS] OPs has become more pronounced in the 2014-2020 programming period. The two most significant developments are a decline in the use of social in [OMS/NMS] OPs and a dramatic rise in the use of innovation in [OMS/OMS] OPs.

Analysis of the three categories over time reveals that the increased frequency of the term innovation for all German OPs (Fig. 3, left side) derives exclusively from [OMS/OMS] OPs. This is the case, because over the two programming periods, the frequency of innovation rises steeply in [OMS/OMS] OPs (Fig. 4), but declines in [OMS/ NMS] OPs (Fig. 5).

Moreover, when it comes to [OMS/NMS] OPs (Fig. 5), only the concept of growth became more frequent in the later period. In fact, while growth was one of the least frequent concepts under investigation in the 2007-2013 programming period, in the 2014-2020 programming period, it became the second most frequent. Simultaneously a notable decline in the use of the term cohesion could be observed. Nevertheless, despite declining frequency, social remained the most frequently used term in [OMS/NMS] OPs.

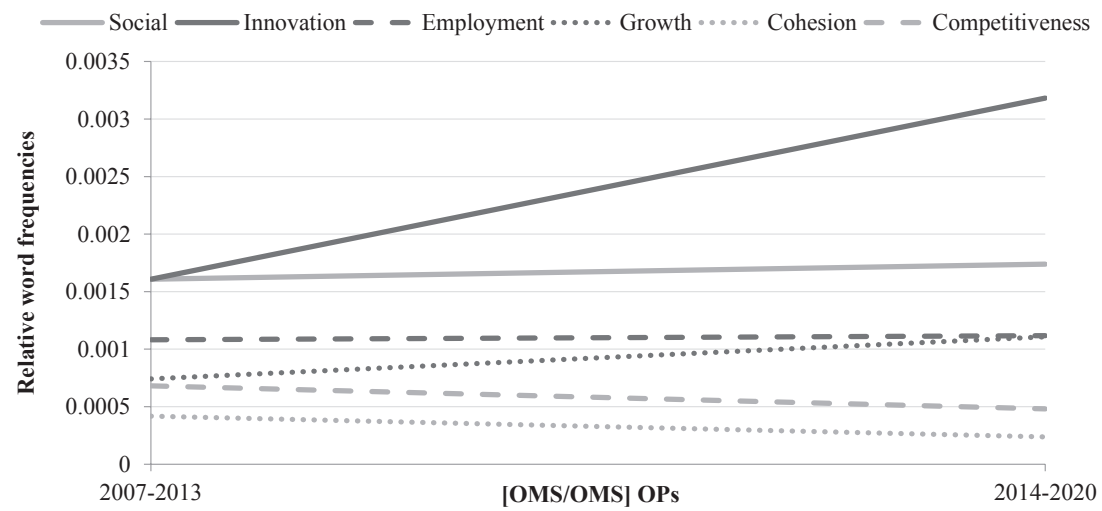

Fig. 4 Trend analysis of [OMS/OMS] OPs across the 2007-2013 and the 20142020 period (Source Own elaboration based on Sinclair and Rockwell 2017) 


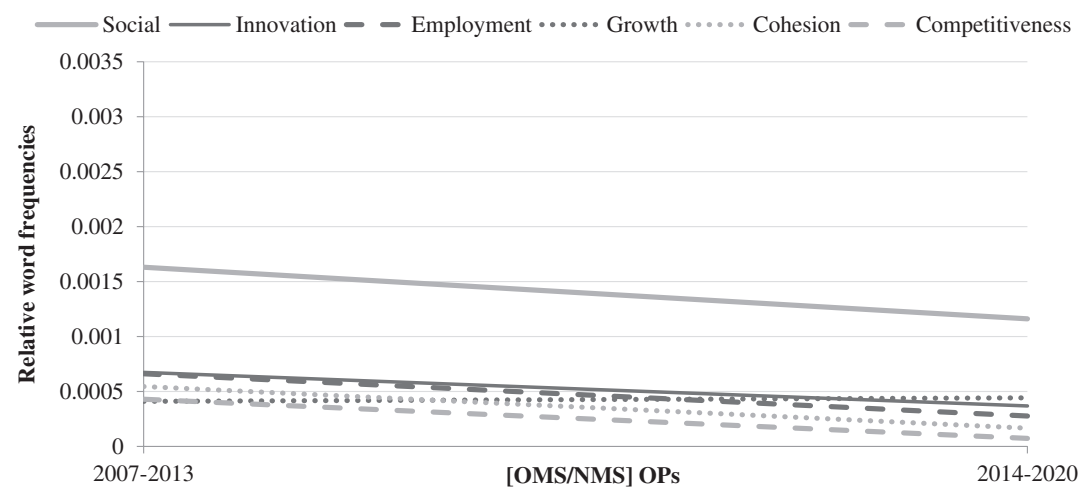

Fig. 5 Trend analysis of [OMS/NMS] OPs across the 2007-2013 and the 20142020 period (Source Own elaboration based on Sinclair and Rockwell 2017)

The analysis of [NMS/NMS] OPs shows that while the concepts growth and employment have become more frequent in [NMS/NMS] OPs, cohesion has become less so (Fig. 6). Moreover, the term innovation has become only slightly more prevalent in the 2014-2020 programming period. This means that almost the entire increase in the use of innovation across all Czech OPs (Fig. 3, right side) derives from [OMS/ NMS] OPs. Considering that [OMS/NMS] OPs referred to innovation less frequently than [OMS/OMS] OPs in the 2007-2013 period,

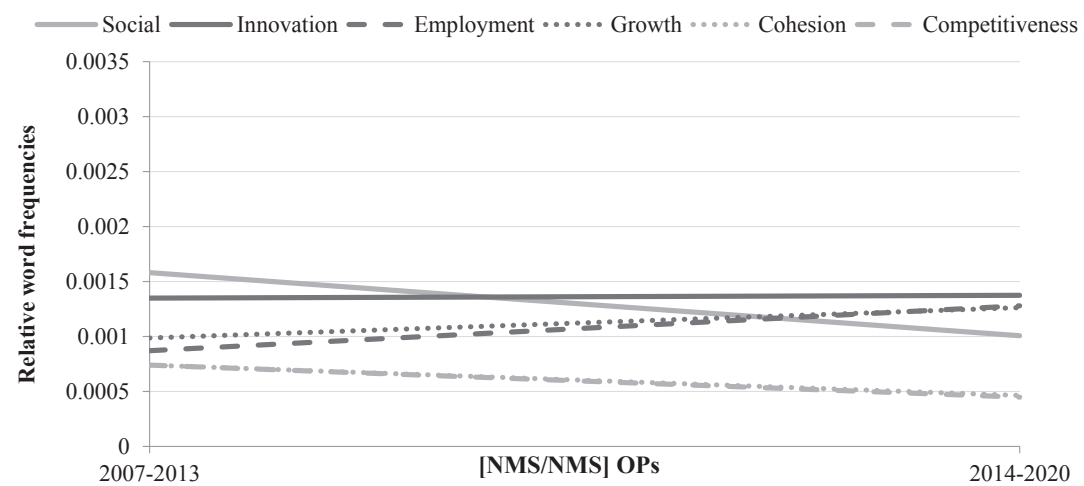

Fig. 6 Trend analysis of [NMS/NMS] OPs across the 2007-2013 and the 20142020 period (Source Own elaboration based on Sinclair and Rockwell 2017) 


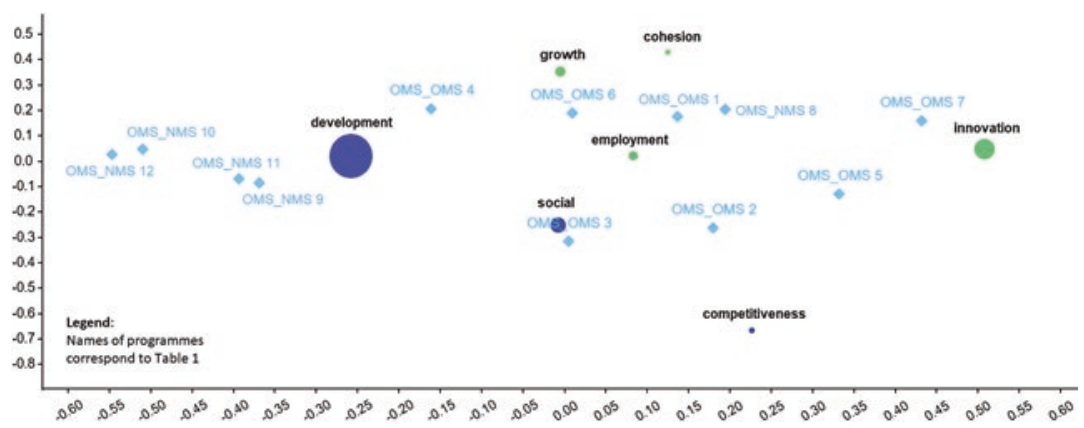

Fig. 7 Correspondence analysis for all German cross-border OPs (2014-2020) (Source Own elaboration based on Sinclair and Rockwell 2017)

a clear ordering of the three categories has emerged in the 2014-2020 period for the term innovation: [OMS/OMS] $>[\mathrm{OMS} / \mathrm{NMS}]>[\mathrm{NMS} /$ NMS].

However, comparing Figs. 5 and 6 does not confirm this conclusion. If the [OMS/NMS] and [NMS/NMS] categories feature lower frequencies of innovation than the [OMS/OMS] category, it is surprising that German OPs have lower frequencies than Czech OPs (Fig. 3). These findings are, however, explained by further sub-dividing the [OMS/NMS] category into OPs involving the old German Länder (states) and OPs involving the new German Länder. Additional analysis suggests that OPs involving the new German Länder closely resemble the [NMS/NMS] category, while those involving the old German Länder closely resemble the [OMS/OMS] category.

These findings are also corroborated by correspondence analysis of all German OPs of the 2014-2020 programming period (Fig. 7). First, analysis shows that [OMS/OMS] OPs form a cluster on the left side towards the term innovation. [OMS/NMS] OPs form a cluster on the right side towards the term social. Second, the only exception to this pattern is the Czech-Bavarian OP, which is highly similar to the Austrian-Bavarian OP. Moreover, the same analysis for the 2007-2013 programming period revealed that the Czech-Bavarian OP used to be much more clearly aligned with the other [OMS/NMS] OPs. This drift 
suggests that the Bavarian side largely succeeded in determining the content of the Czech-Bavarian OP in the 2014-2020 programming period. Correspondence analysis, therefore, confirms that there is a significant and growing difference between the old and the new German Länder in terms of OP objectives.

In summary, the analysis found significant changes between the Lisbon Agenda (social and employment) and the Europe 2020 strategy (growth and innovation) and showed that these changes are also visible at the regional level. However, it also highlighted that there are significant differences among the three categories of OPs, which point towards the salience of OMS/NMS cleavage. The chapter now turns to these differences and provides a tentative explanation.

\section{Divergent Paths to Cohesion in Old and New Member States?}

The findings suggest an interesting conclusion about the pathways towards cohesion: at the level of macro strategies, the shift towards innovation and growth suggests that enhancing labour productivity is seen as a core strategy towards greater cohesion. This strategy corresponds to the neoliberal "Competitive Europe" discourse.

However, analysis of the OPs suggests that change in the macro objectives has led to a divergence between OMS and NMS. While the OMS appear to be in line with the liberal ideas of the Europe 2020 strategy, the NMS appear to pursue a different trajectory. In fact, the significant rise in growth and employment in combination with a decline of social in [NMS/NMS] cross-border OPs suggests that labour market participation is a preferred strategy towards cohesion. This strategy corresponds more to the "Social Europe" discourse.

These findings can be interpreted as evidence for the dominance of OMS in framing an increasingly liberal CP paradigm, which NMS are reluctant to adopt. To give a tentative explanation for these different trajectories, this section presents local-level evidence from six cross-border OPs, spanning all three categories. 
First, the interview data confirm that differences in the level of economic development and infrastructure endowment are a major obstacle to determining common OP objectives in [OMS/NMS] programmes. Whereas the Czech and Slovak respondents (NMS) tended to emphasise the lack of public infrastructure on their side of the border, German and Austrian (OMS) respondents tended to highlight the importance of "soft" factors as preconditions for knowledge-based growth. In particular, regional capacities for innovation-driven growth, such as institutions of higher education or high-tech enterprises, exist outside urban agglomerations in federal Germany and Austria, but only to a lesser degree in the more centralised Czech Republic and Slovakia.

Second, there are significant differences in the levels of administrative capacity and autonomy with regard to designing and implementing OPs. For example, German and Austrian federal states are more autonomous and better endowed with financial and human resources than the recently created Czech and Slovak self-governing regions. In the latter countries, key decisions regarding the $\mathrm{CP}$ are usually taken in national ministries. Correspondingly, the interviews suggest that the design and implementation of OPs in the Czech Republic and Slovakia tend to reflect the preferences of national ministries or governments, rather than the conditions in the border region. Moreover, frequent changes of administrative staff in the Czech Republic and Slovakia, often in the aftermath of elections, were associated with a limited capacity to build and retain operational knowledge within the institution responsible for OP administration. This situation supposedly sustains a culture of ad hoc decision-making that is seen as detrimental to the coherent translation of EU-level regulations into national and sub-national policy.

Third, while Austrian respondents repeatedly stressed that CP funds are "expensive money" which demands efficient and accountable spending, Czech and Slovak respondents regularly depicted the OP funds as a way to prop up local budgets. The introduction of thematic priorities in the 2014-2020 programming period was received with scepticism, especially in NMS, where respondents criticised that local conditions and developmental potential are not properly reflected in the thematic priorities (especially with regard to the economic potential of tourism and infrastructure projects). To sum up, different levels of economic 
development and institutional capacity, and different positionalities as net-contributing or net-receiving MS can partially explain the divergent strategies towards cohesion in OMS and NMS.

\section{Conclusion}

The chapter employed an extended methodological framework to address the conceptual ambiguity of cohesion. Building on experimentalist governance theory, it was argued that conceptual clarity is an important precondition for unleashing the CP's virtuous feedback loop. CATA was applied to the EU's macro strategies as well as cross-border OPs to quantify and clarify what lies underneath the conceptual "veil" of cohesion.

The analysis has shown, first, that the EU's macro political objectives evolved from social and employment-related issues in the Lisbon Agenda to growth and innovation-related issues in the Europe 2020 strategy. Second, scrutinising German and Czech cross-border OPs of the 20072013 and 2014-2020 programming periods, the chapter confirmed the trend towards growth and innovation objectives at the regional level. The third part of the analysis revealed a divergent trend among three categories of OPs. While [OMS/OMS] OPs clearly shifted towards an innovation-driven cohesion strategy, this trend was less pronounced in [OMS/ NMS] OPs and in [NMS/NMS] OPs. By contrast, growth and employment objectives became relatively more important in [OMS/NMS] OPs and, especially, in [NMS/NMS] OPs. Subsequently, interview-based evidence from six cross-border OPs was used to suggest potential explanations for this divergence.

We believe that observation of the divergent paths to cohesion raises important questions about their respective long-term trajectories. In terms of economic cohesion, does a place-based CP lead to efficient specialisation or to a polarisation of productivity levels? In terms of social cohesion, will the greater workfare focus in OMS and the greater welfare focus in NMS balance the size of the welfare state and lead to the emergence of a shared European Social Model? In terms of territorial cohesion, what are the implications of the innovation focus in OMS and the social focus in NMS for the relative socio-economic position of urban and rural regions? 
Against this background, we suggest a rethinking of spatial policies in Europe. First, future rounds of CP reforms need to take the "divergent paths" into account and acknowledge the different policy preferences between OMS and NMS regarding cohesion. Second, considering that especially [OMS/NMS] programmes struggle to determine shared cross-border objectives, the legal instrument of European Groupings of Territorial Cooperation should be mainstreamed as a solution to the problem of political bargaining that surrounds national funding envelopes. Third, the recent proposal of the EU Commission to concentrate future CP funding exclusively in below-average GDP MS should be combined with a stronger focus on the promotion of good governance and systematic institutional capacity building.

While the chapter has presented an innovative methodology for unveiling divergent paths between OMS and NMS, the analysis was restricted to a limited number of MS as well as to cross-border OPs. Future research can build on the methodological foundations presented in this chapter, to test the validity of the presented results with a broader corpus of policy documents. Moreover, regarding experimentalist governance theory, the methodology can be further developed to allow an analysis of whether and how the pooling and sharing of locallevel experiences impact supranational CP reforms.

\section{Recommendations for Further Readings}

Krippendorff, Klaus. 1980. Content Analysis: An Introduction to Its Methodology. London: Sage.

Leonardi, Robert. 2005. Cohesion Policy in the European Union: The Building of Europe. Basingstoke: Palgrave Macmillan.

Rodríguez-Pose, Andrés, and Katja Novak. 2013. "Learning Processes and Economic Returns in European Cohesion Policy." Investigaciones Regionales 25: 7-26.

Sabel, Charles F., and Jonathan Zeitlin. 2008. "Learning from Difference: The New Architecture of Experimentalist Governance in the EU." European Law Journal 14 (3): 271-327. https://doi. org/10.1111/j.1468-0386.2008.00415.x.

Zeitlin, Jonathan. 2015. Extending Experimentalist Governance: The European Union and Transnational Regulation. Oxford: Oxford University Press. 


\section{References}

Avdikos, Vasilis, and Anastassios Chardas. 2016. "European Union Cohesion Policy Post 2014: More (Place-Based and Conditional) Growth-Less Redistribution and Cohesion." Territory, Politics, Governance 4 (1): 97-117. https://doi.org/10.1080/21622671.2014.992460.

Bachtler, John, and Carlos Mendez. 2007. "Who Governs EU Cohesion Policy? Deconstructing the Reforms of the Structural Funds." Journal of Common Market Studies 45 (3): 535-64. https://doi. org/10.1111/j.1468-5965.2007.00724.x.

Barca, Fabrizio. 2009. "An Agenda for a Reformed Cohesion Policy: A PlaceBased Approach to Meeting European Union Challenges and Expectations." Independent Report Prepared at the Request of the European Commissioner for Regional Policy, Danuta Hübner. Brussels: European Commission. http://www.europarl.europa.eu/meetdocs/2009_2014/documents/regi/dv/ barca_report_/barca_report_en.pdf.

Berg, Bruce L. 2001. Qualitative Research Methods for the Social Sciences. 4th ed. Boston: Allyn \& Bacon.

Bruszt, László. 2008. "Multi-Level Governance-The Eastern Versions: Emerging Patterns of Regional Developmental Governance in the New Member States." Regional and Federal Studies 18 (5): 607-27. https://doi. org/10.1080/13597560802351622.

Craciun, Daniela. 2018. "Topic Modeling: A Novel Method for the Systematic Study of Higher Education Internationalization Policy.” In The Future Agenda for Internationalization in Higher Education, edited by Laura E. Rumbley and Douglas Proctor. Abingdon: Routledge (forthcoming).

De Búrca, Gráinne, Robert O. Keohane, and Charles F. Sabel. 2014. "Global Experimentalist Governance.” British Journal of Political Science 44 (3): 477-86. https://doi.org/10.1017/S0007123414000076.

Demidov, Andrey. 2015. "Partnership Principle for Structural Funds in the New Member States. Understanding Contestation over the EU Requirements." PhD thesis, Central European University Budapest. http:// www.etd.ceu.hu/2014/demidov_andrey-anatolievich.pdf.

Dunning, Thad. 2017. "Improving Causal Inference: Strengths and Limitations of Natural Experiments." Political Research Quarterly 61 (2): 282-93. https://doi.org/10.1177/1065912907306470.

European Commission. 2010. "Europe 2020: A Strategy for Smart, Sustainable and Inclusive Growth." COM (2010) 2020 final. Brussels: 
European Commission. http://ec.europa.eu/eu2020/pdf/COMPLET\%20 EN\%20BARROSO\%20\%20\%20007\%20-\%20Europe\%202020\%20 -\%20EN\%20version.pdf.

European Council. 2000. "Lisbon European Council. 23 and 24 March 2000. Presidency Conclusions." http://www.europarl.europa.eu/summits/lis1_en.htm. European Parliament and Council. 2013. "Regulation (EU) No 1303/2013 of the European Parliament and of the Council of 17 December 2013." https://eur-lex.europa.eu/legal-content/EN/TXT/?uri=celex:32013R1303.

Faludi, Andreas. 2008. "The Learning Machine: European Integration in the Planning Mirror." Environment and Planning A: Economy and Space 40 (6): 1470-84. https://doi.org/10.1068/a39225.

Faludi, Andreas. 2010. Cohesion, Coherence, Cooperation: European Spatial Planning Coming of Age? Abingdon: Routledge.

Forgó, Balázs, and Anton Jevčák. 2015. "Economic Convergence of Central and Eastern European EU Member States over the Last Decade (20042014).” Discussion Paper 001, Publications Office of the European Union, Luxembourg.

Greenacre, Michael. 2010. "Correspondence Analysis." In International Encyclopedia of Education, edited by Penelope Peterson, Eva Baker, and Barry McGaw, 103-11. Oxford: Elsevier.

Hooghe, Lisbet. 1996. Cohesion Policy and European Integration: Building Multi-Level Governance. Oxford: Oxford University Press.

Krippendorff, Klaus 1980. Content Analysis: An Introduction to Its Methodology. London: Sage.

Lang, Thilo, Sebastian Henn, Wladimir Sgibnev, and Kornelia Ehrlich, eds. 2015. Understanding Geographies of Polarization and Peripheralization: Perspectives from Central and Eastern Europe and Beyond. New Geographies of Europe. Basingstoke: Palgrave Macmillan.

Lehecka, Tomas. 2015. "Collocation and Colligation." In Handbook of Pragmatics, edited by Jan-Ola Östman and Jef Verschueren. Amsterdam: John Benjamins.

Leonardi, Robert. 2005. Cohesion Policy in the European Union: The Building of Europe. Basingstoke: Palgrave Macmillan.

Manzella, Gian Paolo, and Carlos Mendez. 2009. "The Turning Points of EU Cohesion Policy.” Report Working Paper. http://ec.europa.eu/regional_policy/archive/policy/future/pdf/8_manzella_final-formatted.pdf.

Medve-Bálint, Gergő. 2014. "Converging on Divergence: The Political Economy of Uneven Regional Development in East Central Europe (1990-2014)." 
$\mathrm{PhD}$ thesis, Central European University Budapest. http://pds.ceu.edu/sites/ pds.ceu.hu/files/attachment/basicpage/478/medve-balintgergoir.pdf.

Mendez, Carlos. 2011. "The Lisbonization of EU Cohesion Policy: A Successful Case of Experimentalist Governance?" European Planning Studies 19 (3): 519-37. https://doi.org/10.1080/09654313.2011.548368.

Molle, Willem. 2007. European Cohesion Policy. Abingdon: Routledge.

Neacsu, Milica, and Wolfgang Petzold. 2015. "Policy Learning and Transfer in EU Cohesion Policy: The Impact of Events." Paper Presented at the Conference "Cross-National Policy Transfer in Regional and Urban Policy", 19 January, Delft.

Newell, Sue. 2005. "Knowledge Transfer and Learning: Problems of Knowledge Transfer Associated With Trying To Short-Circuit the Learning Cycle." Journal of Information Systems and Technology Management 2 (3): 275-90.

Rodríguez-Pose, Andrés, and Katja Novak. 2013. "Learning Processes and Economic Returns in European Cohesion Policy." Investigaciones Regionales 25: 7-26.

Sabel, Charles F., and Jonathan Zeitlin. 2008. "Learning from Difference: The New Architecture of Experimentalist Governance in the EU." European Law Journal 14 (3): 271-327. https://doi. org/10.1111/j.1468-0386.2008.00415.x.

Sabel, Charles F., and Jonathan Zeitlin. 2010. Experimentalist Governance in the European Union: Towards a New Architecture. Oxford: Oxford University Press.

Sabel, Charles F., and Jonathan Zeitlin. 2012. "Experimentalist Governance." In The Oxford Handbook of Governance, edited by David Levi-Flaur. Oxford: Oxford University Press.

Sartori, Giovanni. 1970. "Concept Misformation in Comparative Politics." The American Political Science Review 64 (4): 1033-53. https://doi. org/10.2307/1958356.

Scharpf, Fritz W. 1997. Games Real Actors Play: Actor-Centered Institutionalism in Policy Research. Boulder: Westview Press.

Sinclair, Stéfan, and Geoffrey Rockwell. 2017. "Voyant Tools." https://voyant-tools.org/.

Waterhout, Bas. 2008. The Institutionalisation of European Spatial Planning. Amsterdam: Delft University Press.

Zeitlin, Jonathan. 2015. Extending Experimentalist Governance: The European Union and Transnational Regulation. Oxford: Oxford University Press. 
Open Access This chapter is licensed under the terms of the Creative Commons Attribution 4.0 International License (http://creativecommons. org/licenses/by/4.0/), which permits use, sharing, adaptation, distribution and reproduction in any medium or format, as long as you give appropriate credit to the original author(s) and the source, provide a link to the Creative Commons license and indicate if changes were made.

The images or other third party material in this chapter are included in the chapter's Creative Commons license, unless indicated otherwise in a credit line to the material. If material is not included in the chapter's Creative Commons license and your intended use is not permitted by statutory regulation or exceeds the permitted use, you will need to obtain permission directly from the copyright holder. 


\section{Urban Growth Pole Policy and Regional Development: Old Wine in New Bottles?

\author{
József Benedek, Ștefana Varvari \\ and Cristian Marius Litan
}

\section{Introduction, Theoretical Background, Goals and Methodology}

The concept of growth poles has been introduced by the French economist Francois Perroux (Perroux 1950, 1988) and further developed by Jacques-Raoul Boudeville and José Ramón Lasuén (Lasuén 1973; Schätzl 1998). These authors consider growth poles as urban centres polarising a larger region, where a single large firm or an economic sector generates a growth process, and where sectorial polarisation determines the regional polarisation of firms and population (Benedek and Moldovan 2015). The intensity of regional polarisation depends on the market share size of the dominant economic sector, and can be counterbalanced through the establishment of new growth centres, which may reshape the regional spatial structure.

J. Benedek (凹) · Ş. Varvari · C. M. Litan Babeş-Bolyai-University, Cluj-Napoca, Romania 
An important effect is attributed to growth poles, namely that they can bring about spatial diffusion of growth towards their zone of influence.

In his overview of growth pole strategies, Parr (1999) demonstrated how the scientific concept of dominance and economic space elaborated by François Perroux became a normative concept in regional economic planning. Moreover, Lang and Török demonstrated in a recent paper how the view of supporting metropolitan areas as national growth engines also became a central element of national urban policies (Lang and Török 2017). The greatest academic and practical interest in growth pole strategies characterised the period from the mid-1960s to the mid-1970s (Parr 1999). However, it failed to achieve its main objective, namely the diffusion of growth, and was consequently largely abandoned in the period following the mid-1970s. For this reason, its revival during the 2000s in Europe came as a surprising evolution.

Against this background, the main aim of this chapter is to evaluate the process and outcome of establishing urban growth poles as key elements of the new regional policy in Romania. This question is particularly relevant for the production and reproduction of socio-spatial disparities. Therefore, we will address in particular the question of whether the strong prioritisation of urban growth poles has reduced or increased regional disparities in Romania in demographic and economic terms. The evaluation of urban growth poles will follow a twofold logic: one is based on quantitative estimation of the economic effects of the urban growth pole strategy (priority axis 1, ROP 2007-2013); the second line of argumentation evaluates the qualitative effect of the growth pole strategy in relation to the main objectives of the major strategic planning documents: Law 315/2004 on regional development and the National Strategic Reference Framework (NSRF) for the period 2007-2013. We argue that growth pole strategies have different features within the Romanian planning context reflecting space, society and governance. Our aim is not to come up with a "total impact" assessment 
but rather to emphasise the "conditioning factors" of growth pole policy effectiveness (Fratesi and Wishlade 2017).

\section{Setting the Scene for the Growth Pole Strategy: Regional Inequalities in Romania}

Following EU accession in 2007, internal spatial inequalities have increased significantly in Romania (Benedek and Török 2014). This process is not particularly specific to Romania, being significant in other CEE countries as well. Moreover, the idea is generally accepted that regional disparities tend to increase during phases of national economic growth, followed by a phase of decrease. According to this perspective, the increase of economic inequalities in Romania seems to fit into this general picture. The difference in GDP per capita from the EU average $(\mathrm{EU} 28=100)$ of the poorest (Nord-Est 34) and richest (București-Ilfov 136) Romanian NUTS-2 region reached in 2015 its maximum level (Eurostat 2017). It is an expression of the strong spatial concentration on the development of very few regions, mostly the capital region. This value is exceeded only by four EU countries (France, Slovakia, Belgium and Germany). If we compare the gaps in GDP per capita from the EU average between the poorest and richest NUTS-2 regions for 2015 and 2004 (102, respectively 40), we see a strong internal spatial polarisation process in a short period of time, unique among EU countries. At the same time, Romania converged significantly at the national level: GDP per capita compared to the EU average increased from $26 \%$ in 2000 to $49 \%$ in 2012, achieving and exceeding the main goal set in the NSRF 2007-2013: increasing GDP per capita in Romania by $15-20 \%$ by 2015 .

In other words, the external, country-level convergence to the EU average was accompanied by a strong internal territorial polarisation, creating a dual spatial structure (Benedek 2015). This development contradicts the regional development goals based upon the principles of 
subsidiarity, decentralisation and partnership set out in the main planning document, the Regional Development Act 315/2004.

\section{The Growth Pole Strategy of Romania: Description and Implementation}

Generally, the Romanian case confirms the findings of the territorial governance and regional studies literature which states that EU Cohesion Policy has two major territorial influences: first, it has contributed to a change in the structure of territorial administration with the creation of development regions and a corresponding new institutional framework at the regional level, and, second, it has contributed to a change in the territorial relations between institutions and across different levels of territorial government (Bachtler and McMaster 2008). Before EU accession, it was an obligation for the EU candidate country Romania to meet the requirements of Chapter 21 of the acquis communautaire which sets the conditions and rules for regional policy and requires adoption of the NUTS system. The European Commission (EC) exercises in this way huge influence over the outcome. In addition, the pre-accession EU funding programmes PHARE, ISPA and SAPARD supported among other activities the institution building process. However, the EC does not regulate the status of regional institutions in the member states, which has hindered deeper regionalisation. In other words, the EC has contributed little to the strengthening of regional powers and resources in CEE (Bachtler and McMaster 2008).

The Regional Development Act adopted in 1998 and subsequently amended in 2004 stipulates three fundamental principles (subsidiarity, decentralisation and partnership), as well as three fundamental goals (reduction of regional disparities, regional harmonisation of sectoral government policy, supporting regional collaboration) of regional policy. These goals are part of the uncritically adopted European policies in Romanian spatial planning following the collapse of communism (Stringer et al. 2009; Tănăsoiu 2012; Benedek 2014). As part of this 
process the general guidelines and principles of the European spatial planning documents have been superseded by the Romanian spatial planning system (Pușcaşu 2009; Cotella et al. 2012; Benedek 2013; Benedek and Cristea 2014). More specifically, the NSRF 2007-2013 defines five EU-financed development priorities (Government of Romania 2007), among them sustaining a balanced territorial development which represents an adoption of mainstream European spatial documents. A second main development goal of Romania was the reduction of the economic and social disparities between Romania and other EU member states by a GDP increase of $15-20 \%$ by 2015 . These main goals were supported - within the scope of convergence-by seven Operational Programmes (OP). The stated strategic goal of one of these, the Regional Operational Programme (ROP), was to support balanced and sustainable regional development. This is further sustained by five specific aims: increasing the social and economic importance of cities; applying the principle of polycentric development; providing better access to regions, especially by enabling access to city centres and improving public transportation in cities and their surrounding areas; improving regional social infrastructure; enhancing regional competitiveness; increasing the regional economic importance of tourism (MRDT 2012). All except one (tourism) targeted cities, the first two expressly, the next two indirectly. The support given to social and economic infrastructure development was concentrated in cities (Benedek 2016). In other words, the specific aims attributed to the strategic goal of regional development gave a structural advantage to NUTS-3 units (counties) with higher urbanisation rates, contributing in this way to the widening of regional disparities. Within the ROP, each goal was assigned to a priority axis and the corresponding budget allocation, all of which favoured large urban concentration: (1) sustainable development of city growth poles $31.36 \%$; (2) improvement in regional and local transportation infrastructure $19.76 \%$; (3) improvement in social infrastructure $14.81 \%$; (4) consolidation of regional and local business environments $17.93 \%$; development and promotion of tourism 16.14\% (MRDT 2012). The projects implemented in Axis 1 of the ROP amounted to 
around 2.26 billion EUR, of which 621 million EUR were dedicated to just seven growth poles.

These seven urban growth poles have been defined in Law 1149/2008 of Urban Growth Centres as polarising cities, transport hubs, concentrating economic and cultural activities, which will benefit by being given priority for from European and national financing (MRDPA 2008; MRDT 2012). In addition, the same law has defined 13 urban development poles and 170 urban centres as parts of a polycentric regional development policy.

One specific feature of the growth pole strategy in Romania is represented by its strong connection to urban development and planning. All growth poles follow the classification of urban centres by Law 351/2001 National Spatial Development PlanSection 4: The Settlement Network, which has differentiated 12 upper tier cities: the capital city Bucharest (ranked 0) and 11 other cities ranked 1 . The seven growth poles were selected from the latter category, one from each development region except the capital region: Cluj-Napoca, Iași, Timișoara, Constanța, Craiova, Brașov and Ploiești.

The same is valid for their governance structure, the newly created metropolitan areas being based in the same legal framework, where metropolitan areas are defined as "territories surrounding major urban agglomerations, where strong transportation, economic, social, cultural and infrastructural interrelations are established" (RP 2001). They differ from the "Suburban Areas", which are "territories surrounding cities, where economic, infrastructural, commuting and leisure interdependencies are established" (RP 2001).

The seven designated growth poles established associations of local administrations called "metropolitan areas" with their neighbouring settlements, an eligibility requirement to obtain European Regional Development Fund (ERDF) funding through the 2007-2013 ROP for urban integrated development projects.

They received ERDF financial support to implement so-called Integrated Urban Development Plans, planning documents that were supposed to identify urban and metropolitan areas in need of urban 
integrated development investments (urban, transport, social and economic infrastructure) (Benedek and Cristea 2014).

\section{Impact Evaluation of the Growth Poles Programme from the Perspective of Regional Inequalities}

\subsection{Data}

In order to estimate the impact of the growth poles policy during the 2007-2013 programming period we took into consideration two main indicators: population by residence as at 1 January each year and local public administration's own incomes for each year for each administrative-territorial unit of Romania (own incomes are mainly made up of local taxes, fees and income tax payable by residents, economic agents, legal entities and public institutions of local importance). The time period analysed is 2004-2016 and was divided into three subperiods: 2004-2007 (pre-programming period), 2007-2013 (programming period) and 2014-2016 (post-programming period). We have to mention that Romania only started to receive European funds after 2009 and received some of them after the programming period ended (in 2014-2016). Population data were collected from official statistics provided by the National Statistics Institute (http://statistici.insse. ro/shop/), and official data for own incomes from the Department for Fiscal Policy and Local Budgeting within the Ministry of Regional Development, Public Administration and European Funds from income and expenditure statements at the administrative-territorial unit level (http://www.dpfbl.mdrap.ro/sit_ven_si_chelt_uat.html).

\subsection{Methodology}

The data for each year were collected at NUTS-5 level and aggregated at county level. Taking into consideration the way in which the cities 
were classified for the 2007-2013 programming period, we organised the data in three groups of counties (the groups were determined by the different types of urban areas in the county that received funding over the 2007-2013 programming period from the Regional Operational Programme Axis 1): Group 1, representing the growth poles and the counties that had growth poles; Group 2, representing the urban development poles and the counties that had urban development poles; and Group 3, representing urban centres and counties with urban centres. Because Bucharest is a much more highly developed municipality than the rest of the cities, it was excluded from the analysis in order not to distort the results. For each county and for every year of the analysed period, we calculated the income disparities among the cities within the same county and income disparities between all localities in the county, even rural ones, respectively. Furthermore, we conducted two types of analysis: (1) comparison between Group 1 (treated) and the rest of the country (Groups 2 and 3-non-treated); (2) comparison between Groups 1 and 2 (treated) and the rest of the country (Group 3-nontreated) in order to assess the changes in disparities during the analysed period and draw some conclusions regarding changes in the three different sub-periods of time and the effect that the input of European funds might have had in this evolution.

Inequalities/disparities were measured using Gini coefficients, which were based on own income per capita of localities, as shown in the following formulas:

$$
G_{-} \text {cities }_{k, t}=\frac{\sum_{i=1}^{n_{k t}} \sum_{j=1}^{n_{k t}}\left|x_{i k t}-x_{j k t}\right|}{2 \cdot n_{k t} \cdot \sum_{i=1}^{n_{k t}} x_{i k t}}
$$

where $k$ represents the county, $t$ represents the year for which the Gini coefficient characterising the county is calculated, $n_{k t}$ represents the total number of cities in the county $k$ in year $t$ (usually constant for the analysed period), $x_{i k t}$ represents own income per capita in year $t$ for city $i$ in county $k$. 


$$
G \_ \text {alloc }_{k, t}=\frac{\sum_{i=1}^{m_{k t}} \sum_{j=1}^{m_{k t}}\left|x_{i k t}-x_{j k t}\right|}{2 \cdot m_{k t} \cdot \sum_{i=1}^{m_{k t}} x_{i k t}}
$$

where $k$ represents the county, $t$ represents the year for which the Gini coefficient characterising the county is calculated, $m_{k t}$ represents the total number of administrative-territorial units in county $k$ in year $t$ (usually constant for the analysed period), $x_{i k t}$ represents own income per capita in year $t$ for locality $i$ in county $k$.

According to the proposed grouping of the counties $k$ belongs to $G R 1 \cup G R 2 \cup G R 3$, where $G R 1$ are those counties which had growth poles, $G R 2$ is the group of those counties which had urban development poles and $G R 3$ is represented by the rest of the counties. The groups $\left\{G R_{i}\right\}_{i=1,3}$ represent a partition of the total set of counties (except for Ilfov county, which includes the city of Bucharest). Nevertheless, if we calculated the Gini coefficient of the Ilfov county without considering the city of Bucharest, the results did not qualitatively change irrespective of including this country in the analysis of $G R 3$ or not.

In this chapter we have not considered analysing the amount per capita received by different urban areas through the ROP Axis 1. Understanding such an influence remains for further research. Our purpose here in partitioning the set of counties was to get a clear picture of the way municipalities were treated and how they benefited through the ROP.

Both analyses conducted are concerned with the mean comparison of disparities between treated and non-treated groups of counties and its evolution in time. The names and definitions of the time series investigated and graphically represented in the next section are relegated to Table 1 (see Appendix).

Since one of our aims in this chapter was to understand the time pattern of the difference between the (average) disparities in treated counties and the (average) disparities in non-treated ones, we also employed statistical tests to determine whether, at a specific moment in time, the distributions of Gini coefficients were significantly different between 
the two sets of counties (Student's $t$-test, or the more general MannWhitney $U$-test). Moreover, in the spirit of the difference-in-difference methodology (DID) we also compared the average change over time in the Gini coefficient of the treated group of counties versus the average change over time in the Gini coefficient of the non-treated group (the two moments in time were usually represented by one year within the pre-programming period and another within the post-programming period). Detailed results of statistical tests relating to the next section are available upon request.

There are certain caveats to the presented methodology: the nontreated group of counties cannot really be assimilated to a control group in a natural experiment, the sizes of the groups of counties are small for both parametric and especially non-parametric tests, own income per capita should be robustly tested whether representing or not a good proxy to measure income inequality between the cities/localities within a county, the DID method is subject to certain biases, etc.

Nevertheless, the patterns evidenced by this methodology in the next section should be taken into discussion when evaluating whether the regional policy has achieved its essential objective, which is the reduction of regional disparities.

\subsection{Main Results of the Evaluation}

According to the Final Implementation Report published in March 2017 by the Management Authority of the 2007-2013 ROP, a total sum of EUR 3.97 billion was allocated for the entire programme from the European Regional Development Fund and the absorption rate of community funds was $93.5 \%$, for implementing 4491 finalised projects and the creation of 24,994 jobs. When it comes to Priority Axis 1 (major intervention area 1.1) the situation shows that a total of EUR 1.05 billion was paid to beneficiaries, of which EUR 770 million came from the ERDF, for 505 finalised contracts (the absorption rate from the ERDF was $72 \%$ of the amount allocated for this axis).

This section presents the main results obtained by applying the above methodology in order to see how the disparities within counties changed 
during 2004-2016 and the degree to which funds of different types, allocated through the 2007-2014 ROP, influenced these disparities.

The general picture is shown in Figs. 1-6 in the Appendix. On the one hand, Figs. 1 and 2a show for the whole analysed period a decreasing trend in the Gini coefficients for all groups of counties, when the measure of inequality is calculated only for the cities within a county. However, more careful analysis reveals that the average Gini coefficient for the counties in GR1 has a sharp decrease (except year 2008) until 2009, and then a steady increase until 2014, followed by a slight decrease for the years 2015-2016. The average Gini coefficients of $G R 2$ and $G R 3$ show an almost continuous decrease during the period 2004-2016, except for a sharp increase for the years 2010 and 2011. The average Gini coefficient of the reunion $G R 2 \cup G R 3$ follows the same evolution as each of the individual sets $G R 2$ and $G R 3$ (see Fig. 2a).

On the other hand, Figs. 3 and $4 a$ present the evolution of the average Gini coefficients for the groups of counties, when the measure of inequality is calculated for all localities within a county. In this case the evolution is similar for all three groups, the average Gini coefficients showing an almost continuous decrease until 2014, except for a slight increase for the years 2010 and 2011. There is an abrupt increase in 2015 for all three groups, followed by a decrease in 2016. The average Gini coefficient of the reunion $G R 2 \cup G R 3$ follows the same evolution as each of the individual sets $G R 2$ and GR3 (see Fig. 4a).

When analysing the time pattern of the difference between the average Gini coefficient characterising the counties of $G R 1$ with respect to the average Gini coefficient for the rest of the counties, a clear U-shape pattern can be identified (see Figs. 2b and 4b, Analysis 1).

In Fig. $2 \mathrm{~b}$ this pattern means that the counties in $G R 1$ start with statistically significant higher Gini coefficients than $G R 2 \cup G R 3$ for the pre-programming period (2004-2006), then there are no statistically significant differences between the Gini coefficients for the two groups analysed for most of the programming period (2007-2012, except the year 2008). The difference sharply increases to positive statistically significant values for the post-programming period. (The significance is based on $t$-tests and/or Mann-Whitney tests with a $p$-value $<0.05$. See Fay and Proschan (2010) for a comprehensive 
survey on the ways in which the decision rule and the $p$-value from either test of the two could be associated.) The DID technique proves that the difference in the average Gini coefficient between $G R 1$ and $G R 2 \cup G R 3$ has returned to the same values in the post-programming period as was the case in the pre-programming period. The same qualitative view is offered by Fig. $4 \mathrm{~b}$, when the Gini coefficients as measures of inequality within counties are calculated based on all the localities of a county.

Figure 6 (Analysis 2) presents the evolution of the average Gini coefficients when the treated group is $G R 1 \cup G R 2$ compared with change in $G R 3$ (considered non-treated). Even with this change in the combination of groups, the average Gini coefficients follow the pattern already evidenced by Fig. 3 (see Fig. 6a), and the difference between the average Gini coefficients has a U-shape pattern (see Fig. 6b) similar to that given earlier in Fig. $4 \mathrm{~b}$.

Figure 5 alone does not show the patterns identified. The Gini coefficients calculated based on cities within counties move very close to each other when averaged for $G R 3$, and $G R 1 \cup G R 2$, respectively.

The most important results of our empirical evaluation can be summarised as follows:

a. during the programming period, the group of counties with growth poles show a steady increase in those Gini coefficients which are based only on cities in the counties;

b. immediately after the programming period, all considered groups of counties exhibit a sharp increase in average in those Gini coefficients which are based on all localities in the counties;

c. the most stable pattern statistically tested is represented by the U-shape difference between the average disparities of treated counties versus non-treated ones (in both Analysis 1 or 2, irrespective of how disparities within a county are calculated). This suggests that the programming period is just a transitory period of uniformity between treated counties and non-treated counties in terms of disparities. Whenever inequality rises again (after the programming period), 
the treated group of counties always increases more rapidly than the non-treated counties.

\section{Regional Policy and Growth Pole Strategy Between 2014 and 2020}

The Partnership Agreement of Romania to the European Commission identifies the following challenges: poor competitiveness, high and rising social inequalities, underdevelopment of transportation and communication infrastructure, low energy efficiency, significant environmental risks and low administrative capacity. They do not differ from the goals of the previous programming period: catching up with the EU average and increasing the employment rate. This is by no means surprising, since the biggest delays have been registered in these two sectors and the rate of employment is closely linked to productivity (Benedek 2016).

Of the European Union's seven-year budget for 2014-2020, Romania will receive resources amounting to 21.826 billion euros, which should sustain the goals of the EU's Cohesion and Rural Development Policies, helping Romania and its regions to catch up with the EU average, as well as improving the competitiveness of agriculture and the retention rate of rural areas.

For the 2014-2020 programming period, approximately the same amount will be allocated for sustainable urban development (Priority Axis 4 of the new ROP set at EUR 1.39 billion, of which EUR 1.18 billion came from European Structural and Investment Funds) as in the previous period (Priority Axis 1 set at EUR 1.35 billion, of which EUR 1.08 billion came from Structural Funds). Of the various regional problems the growth pole strategy was initially set up to address (depressedarea revival, regional deconcentration of population and economy, equilibration of the national urban system, etc.) the pursuit of interregional balance and the reduction of regional disparities therefore represent the prevailing goals of implementing the growth pole concept in the Romanian context. 
Considering increasing criticism of concentrating public resources in a small number of growth poles in the 2007-2013 programming period, the Romanian Regional Development Strategy for the 2014-2020 cycle proposes a new approach, in which more attention is given to medium-size cities, especially the ones with the capacity to spread growth in their surroundings (Benedek and Cristea 2014).

To this end a new urban ranking methodology has been proposed by the Romanian Ministry of Regional Development and Public Administration for the 2014-2020 ROP. While the initial proposal was based on demographic, economic, accessibility and geographic criteria, the final outcome reflects rather a simplistic view: all county seats will function as growth poles (39 county seats), except Tulcea, which will benefit from the Danube Delta Integrated Territorial Investment instrument and the municipality of Bucharest, which is the country capital and is considered a more developed region at the EU level, its GDP/ capita surpassing the EU average.

These county seats are eligible for funding under Axis 4 "Support sustainable urban development" of the 2014-2020 ROP. Main priority investments refer to: public transport based on Sustainable Urban Mobility Plans (roads, bike paths, acquisition of green/electric vehicles, etc.), rehabilitation of urban areas (brownfield redevelopment, etc.), urban marginalised communities (educational, cultural, and recreational facilities, green areas, public squares, parks, urban streets, and small-scale public utilities) and educational infrastructure (nurseries, kindergartens, technical and professional high-schools).

As a prerequisite for obtaining funds through Axis 4 of the new ROP, the 39 county seats must put together an integrated urban development strategy at the administrative territorial unit level or the functional urban zone level of the county capital. The strategy should address the economic, environmental, climate, social and demographic challenges of the city (according to Art. 7 of the ERDF Regulation No. 1301/2013). Another novelty in the institutional framework, as specified in Art. 
7 of the Regulation (EU) No. 1301/2013 of the European Regional Development Fund, is the requirement to appoint an "urban authority". These institutions will be established at the county seat level by order of the mayor and act as Intermediate Bodies. The Managing Authority of the ROP will task them with for selecting the priority list of projects to be financed by the Priority Axis 4 of the 2014-2020 ROP and other axes of the ROP, including those which could be funded from other sources (other operational programmes, local budget, national budget, etc.).

\section{Conclusions}

During the transition period, Romania has rapidly adopted the European mainstream discourse on polycentric regional development. Urban growth poles have been defined as main tools in achieving equilibrated spatial development. Classifying the growth pole concept as part of the national urban system represents a specific feature of Romanian planning. Unfortunately, this could have contributed to the widening of regional inequalities. Our empirical analysis suggests that by proceeding in this way the national regional policy might have failed to achieve its main goal: to reduce regional differences at the development level in the medium or long run.

There are other instances of growth pole strategies that present similar stumbling blocks to those in Romania. For example, in the case of Greece (Christofakis and Papadaskalopoulos 2011) critics have focused on such aspects as: the absence of a fixed and long-term typology of urban centres, the lack of empirical studies on the growth potential of designated cities, the absence of additional sectoral policies supporting the growth pole strategy (transportation policy, mobility policy, etc.), urban governance difficulties, absence of integrated development plans.

Urban agglomerations in general and growth poles in particular took centre stage in the current programming period. However, as an 
indirect recognition of the fact that the high prioritisation of urban growth poles development in the previous programming period might have increased the level of regional disparities in Romania, the actual plans expanded the number of growth poles. They included one growth pole for each county (NUTS 3 level), namely their administrative centres. In this way, it is expected that the allocation of different financial instruments to support these new spatial planning categories could be a powerful instrument for the reduction of regional disparities.

The introduction of the growth pole concept in Romania can be considered a good example of the Europeanisation process. Nevertheless, the general guidelines and principles of European spatial planning documents have not been accounted for in a critical way.

The main scientific contribution of this chapter lies in its empirical demonstration of the medium and long run failure of regional policy in achieving its essential objective: the reduction of disparities between different regions/counties.

Indeed, our results show that, irrespective of whether just the cities or all the localities are considered in the calculation of within county inequalities, there is a decreasing trend in disparities within counties along the analysed period. Even so, when looking at different sub-periods of time, it is noticeable that on average the disparities between cities within a county which has a growth pole slowly increased during most parts of the programming period.

Furthermore, analysis of the time pattern of disparities between counties with growth poles (or with urban development centres) and the rest of the counties showed that, for the post-programming period, the former group (treated ones) exhibits a higher pace of re-increasing inequalities within a county than the latter group (nontreated ones). With its focus on sustaining large urban agglomerations, regional policies in Romania do not seem to have a medium- or longterm effect on reducing inequalities within those counties comprising large urban centres. This adds some new arguments to re-thinking spatial policies in Europe in times of increasing local and regional polarisation. 
Our future work will look at the influence that funds from ROP Axis 1 have on the different urban areas. We also want to include the municipality of Bucharest in the analysis, investigate the driving role Bucharest and Ilfov play in regional polarisation, as well as whether the regional policies applied to Romania are able to influence this process. The third direction is to compare treated cities with non-treated localities (cities and rural areas) without aggregation at the county level.

\section{Appendix: Tables and Figures}

See Table 1 and Figs. 1, 2, 3, 4, 5, and 6.

Table 1 The names and definitions of the analysed time series

\begin{tabular}{|c|c|}
\hline Variable name & Definition \\
\hline $\begin{array}{l}\text { GINI_COUNTY_CITIES_GR1 }{ }_{t} \\
\text { GINI_COUNTY_ALLOC_GR } 1_{t}\end{array}$ & 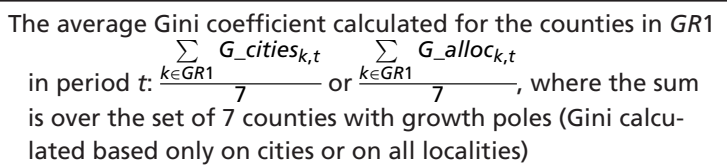 \\
\hline $\begin{array}{l}\text { GINI_COUNTY_CITIES_GR2 }{ }_{t} \\
\text { GINI_COUNTY_ALLOC_GR2 }{ }_{t}\end{array}$ & $\begin{array}{l}\text { The average Gini coefficient calculated for the counties in GR2 } \\
\text { in period } t: \frac{\sum_{k \in G R 2} G_{-} \text {cities }}{13} \sum_{k, t} \text { or } \frac{\sum_{k \in G R 2} G_{-} \text {alloc }}{13} \text { 13,t } \\
\text { sum is over the set of } 13 \text { counties with urban development } \\
\text { centres (Gini calculated based only on cities or on all } \\
\text { localities) }\end{array}$ \\
\hline $\begin{array}{l}\text { GINI_COUNTY_CITIES_GR3 }{ }_{t} \\
\text { GINI_COUNTY_ALLOC_GR3 }{ }_{t}\end{array}$ & $\begin{array}{l}\text { The average Gini coefficient calculated for the counties in GR3 } \\
\text { in period } t: \frac{\sum_{k \in G R 3} G_{-} \text {cities }}{21, t} \sum_{k \in G R 3} G_{-} \text {alloc } c_{k, t} \\
\text { is over the rest of counties (Gini calculated based only on } \\
\text { cities or on all localities) }\end{array}$ \\
\hline $\begin{array}{l}\text { GINI_COUNTY_CITIES_2AND3 }{ }_{t} \\
\text { GINI_COUNTY_ALLOC_2AND }{ }_{t}\end{array}$ & $\begin{array}{l}\text { The average Gini coefficient calculated for the counties in } \\
\qquad G R 2 \cup G R 3 \text { in period } t: \frac{\sum_{G \in G R \cup G R 3} G_{-} \text {cities }_{k, t}}{34} \text { or } \frac{\sum_{k \in G R 2 \cup G R 3} G_{-a l l o c_{k, t}}}{34}\end{array}$ \\
\hline \multirow{3}{*}{$\begin{array}{l}\text { GINI_COUNTY_CITIES_1AND2 }{ }_{t} \\
\text { GINI_COUNTY_ALLOC_1AND2 }{ }_{t}\end{array}$} & (Gini calculated based only on cities or on all localities) \\
\hline & $\begin{array}{l}\text { The average Gini coefficient calculated for the counties in } \\
\qquad G R 1 \cup G R 2 \text { in period } t: \frac{\sum_{k \in G 1 \cup G R 2} G_{-} \text {cities }_{k, t}}{20} \text { or } \frac{\sum_{k \in G 1 \cup G R 2} G_{-} \text {alloc } c_{k, t}}{20}\end{array}$ \\
\hline & (Gini calculated based only on cities or on all localities) \\
\hline
\end{tabular}




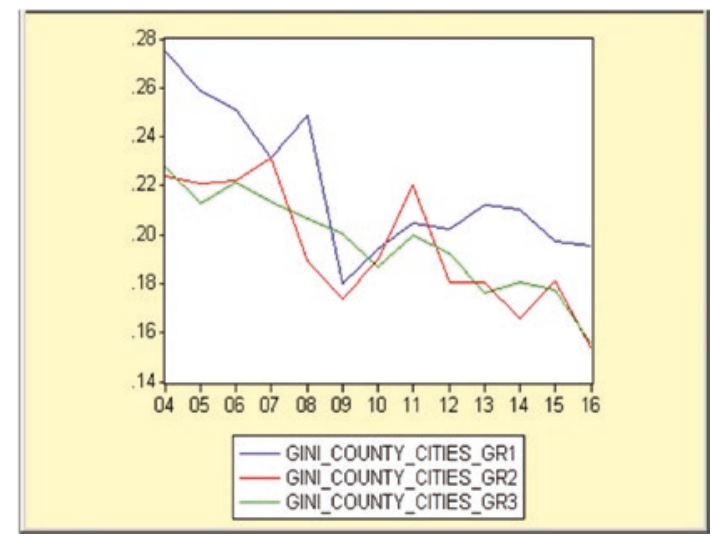

Fig. 1 Evolution in time of average Gini coefficients for all three groups of counties (Gini coefficients are based only on disparities between the cities of a county)

(a)

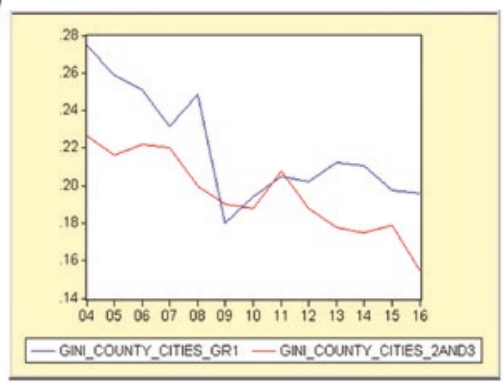

(b)

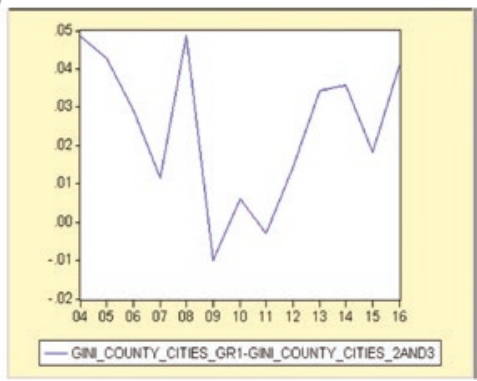

Fig. 2 (Analysis 1): a Evolution in time of average Gini coefficients for $G R 1$

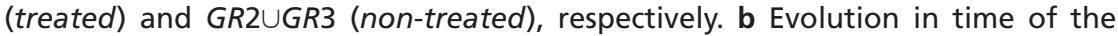
difference between the average Gini coefficients of the treated versus nontreated groups of counties (Gini coefficients are based only on disparities between the cities of a county) 


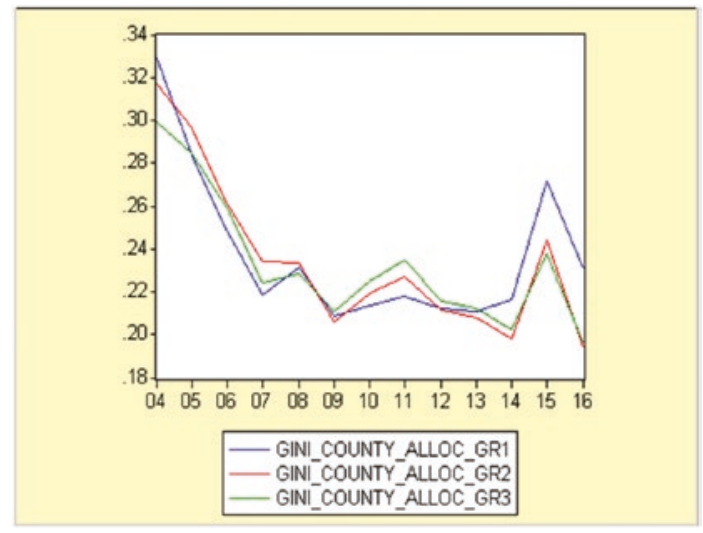

Fig. 3 Evolution in time of average Gini coefficients for all three groups of counties (Gini coefficients are based on disparities between all localities of a county)

(a)

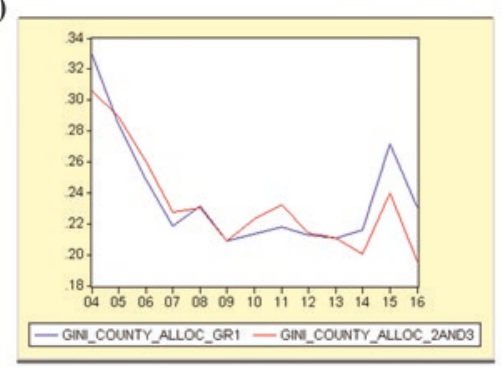

(b)

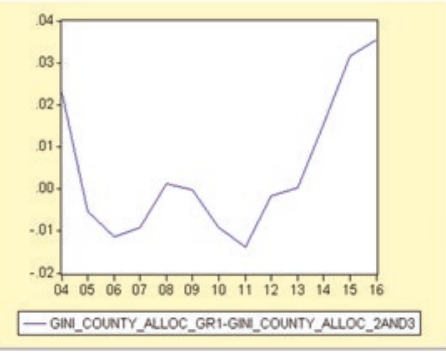

Fig. 4 (Analysis 1): a Evolution in time of average Gini coefficients for GR1

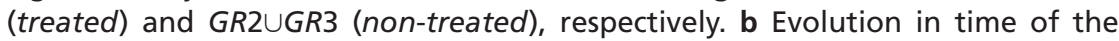
difference between the average Gini coefficients of the treated versus nontreated groups of counties (Gini coefficients are based on disparities between all localities of a county) 
(a)

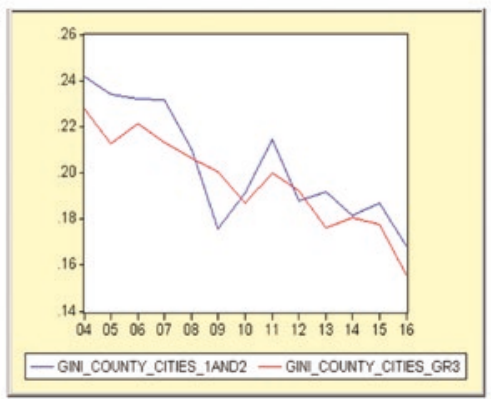

(b)

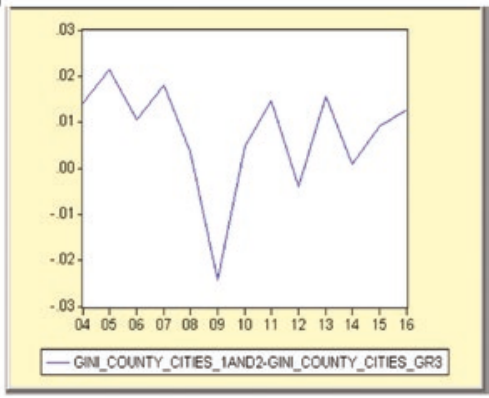

Fig. 5 (Analysis 2): a Evolution in time of average Gini coefficients for GR1 $\cup G R 2$ (treated) and GR3 (non-treated), respectively. b Evolution in time of the difference between the average Gini coefficients of the treated versus non-treated groups of counties (Gini coefficients are based only on disparities between the cities of a county)

(a)

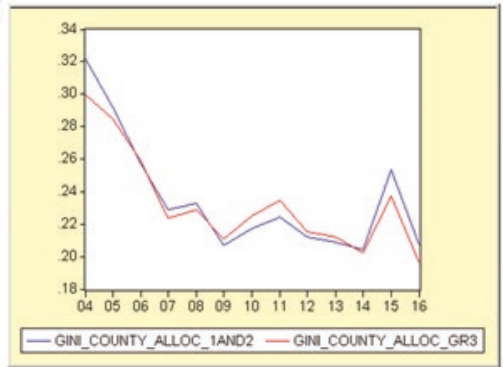

(b)

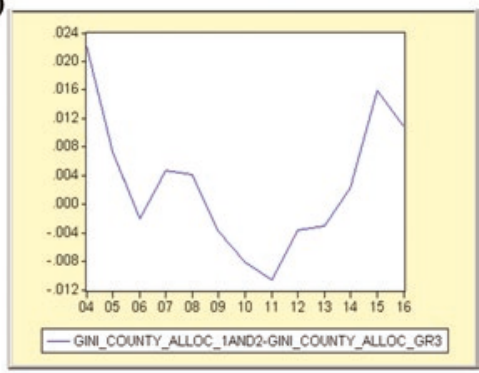

Fig. 6 (Analysis 2): a Evolution in time of average Gini coefficients for GR1 $\cup G R 2$ (treated) and GR3 (non-treated), respectively. b Evolution in time of the difference between the average Gini coefficients of the treated versus non-treated groups of counties (Gini coefficients are based on disparities between all localities of a county) 


\section{References}

Bachtler, John, and Irene McMaster. 2008. "EU Cohesion Policy and the Role of the Regions: Investigating the Influence of Structural Funds in the New Member States." Environment and Planning C: Government and Policy 26 (2): 398-427. https://doi.org/10.1068/c0662.

Benedek, József. 2013. "The Spatial Planning System in Romania." Romanian Review of Regional Studies 9 (2): 23-30.

Benedek, József. 2014. "Regionális fejlesztés és területi kohézió Romániában a 2014-2020-as programozási időszak perspektívájából.” Erdélyi Múzeum 76 (4): 36-48.

Benedek, József. 2015. "Spatial Differentiation and Core-Periphery Structures in Romania." Eastern Journal of European Studies 6 (1): 49-61.

Benedek, József. 2016. "The Role of Urban Growth Poles in Regional Policy: The Romanian Case." Procedia-Social and Behavioral Sciences 223: 28590. https://doi.org/10.1016/j.sbspro.2016.05.368.

Benedek, József, and Ibolya Török. 2014. "County-Level Demographic Disparities in Romania.” Transylvanian Review 23 (2): 138-47.

Benedek, József, and Marius Cristea. 2014. "Growth Pole Development and 'Metropolisation' in Post-Socialist Romania." Studia UBB Geographia 59 (2): 125-38.

Benedek, József, and Aura Moldovan. 2015. "Economic Convergence and Polarisation: Towards a Multi-dimensional Approach." Hungarian Geographical Bulletin 64 (3): 187-203.

Christofakis, Manolis, and Athanasios Papadaskalopoulos. 2011. "The Growth Poles Strategy in Regional Planning: The Recent Experience of Greece." Theoretical and Empirical Researches in Urban Management 6 (2): 5-20.

Cotella, Giancarlo, Neil Adams, and Richard Joseph Nunes. 2012. "Engaging in European Spatial Planning: A Central and Eastern European Perspective on the Territorial Cohesion Debate." European Planning Studies 20 (7): 1197-220.

European Commission. 2013. "Regulation (EU) No. 1301/2013 of the European Parliament and of the Council of 17 December 2013 on the European Regional Development Fund and on Specific Provisions Concerning the Investment for Growth and Jobs Goal and Repealing Regulation (EC) No. 1080/2006.” https://eur-lex.europa.eu/legal-content/ $\mathrm{EN} / \mathrm{TXT} / \mathrm{PDF} /$ ?uri=CELEX:32013R1301\&from $=\mathrm{EN}$. 
Eurostat. 2017. Newsrelease 52/2017-30 March 2017. http://ec.europa.eu/eurostat/documents/2995521/7962764/1-30032017-AP-EN. pdf/4e9c09e5-c743-41a5-afc8-eb4aa89913f6.

Fay, Michael P., and Michael A. Proschan. 2010. "Wilcoxon-MannWhitney or T-test? On Assumptions for Hypothesis Tests and Multiple Interpretations of Decision Rules." Statistics Surveys 4: 1-39. https://dx.doi. org/10.1214\%2F09-SS051.

Fratesi, Ugo, and Fiona G. Wishlade. 2017. "The Impact of European Cohesion Policy in Different Contexts." Regional Studies 51 (6): 817-21. https://doi.org/10.1080/00343404.2017.1326673.

Government of Romania. 2007. "National Strategic Reference Framework 20072013.” Final Version. Bucharest. http://old.fonduri-ue.ro/res/filepicker_users/ cd25a597fd-62/Doc_prog/CSNR/1_CSNR_2007-2013_(eng.).pdf.

Lang, Thilo, and Ibolya Török. 2017. Metropolitan Region Policies in the European Union: Following National, European or Neoliberal Agendas?" International Planning Studies 22 (1): 1-13. https://doi.org/10.1080/1356 3475.2017.1310652.

Lasuén, José R. 1973. "Urbanisation and Development. The Temporal Interaction Between Geographical and Sectoral Clusters." Urban Studies 10 (2): 163-88. https://doi.org/10.1080/00420987320080281.

Managing Authority for 2007-2013 Regional Operational Programme. 2017. "Final Implementation Report." Bucharest. March. http://www.inforegio. ro/ro/raportari.html.

Ministry of Regional Development and Public Administration (MRDPA). 2008. "Government Decision No. 1149 for the Designation of National Growth Poles."

Ministry for Regional Development and Tourism (MRDT). 2012. "Documentul cadru de implementare a Programului Operaţional Regional 2007-2013" [Framework Document for the Implementation of the Regional Operational Programme 2007-2013]. Bucharest. http://www.fonduri-structurale.ro/Document_Files/Regional/00000026/xv71c_dci_februarie2012.pdf.

Parr, John P. 1999. "Growth-Pole Strategies in Regional Economic Planning: A Retrospective View. Part 1: Origins and Advocacy." Urban Studies 36 (7): 1195-215. https://doi.org/10.1080/0042098993187.

Perroux, François. 1950. "Economic Space: Theory and Applications." Quarterly Journal of Economics 64 (1): 89-104. https://doi.org/10.2307/1881960. 
Perroux, François. 1988. "The Pole of Development's New Place in a General Theory of Economic Activity." In Regional Essays in Honor of Francois Perroux, edited by Benjamin Higgins and Donald J. Savoie, 48-76. Boston: Unwin Hyman.

Pușcașu, Violeta. 2009. “The House of Many Different Ages.” In Planning Cultures in Europe: Decoding Cultural Phenomena in Urban and Regional Planning, edited by Joerg Knieling and Frank Othengrafen, 169-88. Farnham: Ashgate.

Romanian Parlament (RP). 2001. Legea nr. 351 din 14 mai 2001 privind aprobarea Planului de amenajare a teritoriului naţional - Secţiunea a IV-a Reţeana de localităţi. Monitorul Oficial nr. 408 from 24 July. Bucureşti.

Schätzl, Ludwig. 1998. Wirtschaftsgeographie 1. Theorie. Paderborn: UTB.

Stringer, Lindsay C., S. Serban Scrieciu, and Mark S. Reed. 2009. "Biodiversity, Land Degradation, and Climate Change: Participatory Planning in Romania.” Applied Geography 29: 77-90. https://doi. org/10.1016/j.apgeog.2008.07.008.

Tănăsoiu, Cosmina. 2012. "Europeanisation Post-accession: Rule Adoption and National Political Elites in Romania and Bulgaria." Southeast European and Black Sea Studies 12 (1): 173-93. https://doi.org/10.1080/14683857.2 012.661226.

Open Access This chapter is licensed under the terms of the Creative Commons Attribution 4.0 International License (http://creativecommons. org/licenses/by/4.0/), which permits use, sharing, adaptation, distribution and reproduction in any medium or format, as long as you give appropriate credit to the original author(s) and the source, provide a link to the Creative Commons license and indicate if changes were made.

The images or other third party material in this chapter are included in the chapter's Creative Commons license, unless indicated otherwise in a credit line to the material. If material is not included in the chapter's Creative Commons license and your intended use is not permitted by statutory regulation or exceeds the permitted use, you will need to obtain permission directly from the copyright holder.

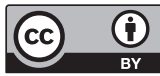




\section{9}

\section{Reproducing Socio-Spatial Unevenness Through the Institutional Logic of Dual Housing Policies in Hungary}

\section{Zsuzsanna Pósfai and Csaba Jelinek}

\section{Introduction}

The increasing role of finance is central to the current transformations of capitalism, with a globally growing amount of money looking for profitable forms of investment (Fernandez and Aalbers 2016). This search for a financial fix systematically channels money towards the built environment-and in certain contexts specifically towards housing (Aalbers 2017). In order to grasp this inherently spatial nature of financialisation (Sokol 2013), we build on the notion of uneven development. Recent work in the field of economic geography aiming to

\section{Z. Pósfai $(\bowtie)$}

Periféria Policy and Research Centre, Budapest, Hungary

C. Jelinek

Centre for Economic and Regional Studies (CERS-HAS), Hungarian Academy of Sciences, Budapest, Hungary

C. Jelinek

Central European University, Budapest, Hungary

(C) The Author(s) 2019

T. Lang and F. Görmar (eds.), Regional and Local Development 
reconceptualise this approach has put specific emphasis on understanding the concrete institutional mechanisms that produce socio-spatial unevenness on various scales (Dunford and Liu 2017; Hudson 2016; Peck 2016). Common to these propositions is the claim that capitalism should be understood as one interconnected and hierarchically structured system; however, empirical emphasis should be put on the intermediary scales of institutional infrastructures, policy developments, firm strategies and subnational spatial patterns in order to understand the mechanisms producing uneven development in a such a varied way. Thus, we approach the issue of spatial polarisation through the perspective of uneven development, since we believe this notion gives us more scope to understand the production of socio-spatial inequality as a multiscalar and non-linear process. Furthermore, we work with this notion because we seek to link our analysis to a body of literature analysing the spatiality of capitalism.

In this chapter, we analyse the development of Hungarian housing policies since the turn of the millennium, investigating how policy interventions reinforce and support the rolling out of uneven socio-spatial development in the field of housing. Housing is an important spatial fix under financial capitalism everywhere in the world; however, the concrete ways in which this is articulated vary across different institutional contexts. We investigate the Hungarian institutional context as situated in a broader, European and global set of hierarchical, interdependent connections. We believe this approach provides useful insights for understanding how policy interventions can channel macroeconomic pressures in a semiperipheral context of the European (and global) economy.

We will not only highlight the role of housing-as-investment, but will also link seemingly more progressive and socially sensitive housing policies to the broader frame of housing under a financialised regime of accumulation. Analysing this branch of policies provides insights into how the state manages spatially concentrated social deprivation in a country with a very minimal share of social/public housing-which is the case for the majority of the Central and Eastern European member states, as well as most countries outside the European Union. 
The starting point of our argument is that Hungarian housing policies are essentially dualised. By dualisation we mean that in a generally fragmented policy arena-since 1989 there has never been a coherent housing policy in Hungary-most individual policy measures intervening in the field of housing either target the relatively well-off upper classes (although claiming to be general in their scope), or very marginalised social groups. The former aim to integrate middle-class households in a financialised housing regime based on individual ownership and debt, while the latter aim to manage and contain spatially concentrated manifestations of housing poverty. We will call these two approaches the liberal and social facets of housing policies. While these policies at the "top" and at the "bottom" of the housing sector are seemingly separate interventions and are never connected narratively by government actors, in our view they are functionally interconnected and should thus be analysed in a holistic manner. This functional interconnection is the most evident when we employ the framework of uneven development. Accepting the claim that global capitalism systematically produces socio-spatial polarisation, we will show how this happens in the field of housing in Hungary through the mediation of certain institutional logics. While dominant (neoliberal) approaches to housing policy are usually planned and executed without reference to their spatial dimension and are claimed to benefit households in a general way, we will demonstrate how they actually reproduce socio-spatial unevenness.

Even though our argument will be rooted in different empirical processes, the main goal of this chapter is to reconstruct the institutional logics behind these spatialities, and not to provide an exhaustive picture of all the empirical aspects of capitalist uneven development in the domain of housing in Hungary.

This study can also provide valuable insights into more general questions about the spatiality of policy intervention in housing under the current wave of financial capitalism. The two modes of intervention which we study adhere to general directions of housing policy development throughout Europe. The dominant model for housing provision in all European countries (and also globally) is to push for indebtedness-based individual homeownership, while marginalised 
social groups living in an increasingly residualised social housing sector are targeted by narrowly focused and often controlling public interventions (Czischke 2009). Furthermore, the vulnerable housing finance system that has developed in Hungary since the late 1990s, based on an externally dependent banking sector, short-term financial resources and individual mortgages (Raviv 2008) is quite typical for all Central and Eastern European countries-although historical and institutional differences are crucial (Bohle 2017). Similarly, the significant role of EU funds in targeting those living in deprived housing conditions is also quite typical for the region. ${ }^{1}$ Thus, our analysis can contribute to a better understanding of variations in Central and Eastern European housing policy, while proposing a more systemic framework of macroeconomic processes driving these contextually specific policy interventions.

The empirical basis of this chapter is anchored in two lots of doctoral fieldwork. Pósfai has been focusing on core-periphery relations embedded in the strategies of housing market actors in Hungary (within the framework of the Marie Curie ITN "RegPol ${ }^{2}$ - Socio-economic and Political Responses to Regional Polarisation in Central and Eastern Europe"), while Jelinek has been working on the history of urban rehabilitations in Hungary from the 1970s (at the Department for Sociology and Social Anthropology of the Central European University). Both researches deployed a mixed methodology: qualitative insights from interviews with the main stakeholders and ethnographic observations of certain key projects were coupled with macrostatistical analyses and with the scrutiny of policy documents and plans. Since the main aim of this chapter is to reconstruct certain institutional logics behind the general trend of uneven development, it will mainly be the interviews conducted during these researches that provide the empirical backbone of our argument. While our understanding of the liberal and social facets of housing policies in Hungary were also informed by quantitative data and document analyses, we will restrict ourselves to the presentation of our most important qualitative findings (occasionally referencing some of our own prior publications using related quantitative data) due to the limited space we have. 
In this chapter we will thus argue that state intervention in the Hungarian housing market is dualistic, with seemingly disconnected policy instruments targeting two ends of the housing spectrum. While the dominant trajectory of neoliberal housing policy in Hungary is to promote indebtedness-based individual homeownership, spatially targeted, small-scale and localised interventions in the public housing stock are meant to correct the exclusionary processes produced by this trajectory, but their effectiveness is highly questionable. State intervention thus reinforces spatial patterns of capitalist development and deepens unevenness of the housing market, while seemingly applying "patches" to the areas that are the most obvious losers of this process.

\section{The Liberal Facet of Housing Policies ${ }^{2}$}

The declared aim of Hungarian housing policy is to promote individual homeownership (Misetics 2017). This has been the very clear political preference of all governments ever since the 1980s, and in the current conservative government this ideology of homeownership is reputed to be unquestionable at the level of the prime minister himself. According to a high-ranking official in the public administration, "the definition of Hungarian housing policy is actually just different forms of subsidies to homeownership". 3 This conservative political preference is of course well in line with and not independent of broader economic processes and general tendencies of liberal housing policies across Europe, which all promote similar aims (Fernandez and Aalbers 2016). Although in this sense the Hungarian housing regime follows the common European (and global) trajectory of housing financialisation described by Fernandez and Aalbers (2016), the concrete ways in which capital is channelled into the housing market are determined by the specific instruments employed.

In the following section we will explore the socio-spatial effects of two of the most important housing policy instruments of the past decades, which were implemented in order to serve the political aim of access to homeownership: (1) a non-refundable state subsidy allocated to families mainly based on the number of children they have 
(previously called szocpol, now called CSOK), and (2) state-subsidised mortgages. These two instruments have shifted in their significance visà-vis each other, and also in their target groups and budgetary weight, but in essence have not changed. Both instruments declaratively serve access to individual homeownership, which is the dominant form of tenure in Hungary (owner occupancy is currently around 90\%). Given the political priority of this aim, these instruments are also the ones that receive the most budgetary support. In 2005, for instance, budgetary resources supporting access to homeownership represented nearly $95 \%$ of all public spending for housing purposes, and this proportion was never less than $85 \%$ during the whole pre-crisis decade (Misetics 2013,52 ). They are articulations of a liberal housing policy at the service of economic actors in the field, and favouring those households that have significant savings, while also pushing for the privatisation of housing-related risks through individual indebtedness (Crouch 2009). We will show how these instruments, in spite of being presented as a generalised housing support to the whole of Hungarian society, framed along the lines of demographics and conservative family politics, are actually channelling resources towards the middle classes (to the detriment of lower social classes), and are also contributing to increasing spatial unevenness.

The first instrument of the liberal facet of housing policy is a state subsidy supporting access to homeownership, which has been in place since 1994 (with a few years' gap after 2009). Concrete allocation criteria have changed throughout the years, but it has always been framed as a demographic/social policy tool (for a long time it was also called the "social policy benefit"—szociálpolitikai kedvezmény, nicknamed szocpol) allocated according to the number of children in a family. Since the early 2000s this has been complemented by the second main instrument of access to homeownership: mortgage lending. Mortgage lending was kick-started by the introduction of a statesubsidised mortgage programme in 2001, and then expanded very rapidly until 2010: there was a 35-fold increase in the stock of outstanding mortgages between 2000 and 2010 (Hegedüs and Somogyi 2016). The subsidised mortgage programme was stopped in 2004, but by then the liberalisation of the banking sector made the widespread 
distribution of cheap mortgages denominated in foreign currencies possible (Pósfai et al. 2018).

Both "strands" are highly publicised housing policy initiatives, but are rarely linked in public discourse. However, they are mutually dependent on each other: the non-refundable housing allocation distributed on a "demographic" basis (szocpol) is rarely sufficient in itself for acquiring property, and its efficiency is thus largely dependent on the availability of mortgages (or significant household savings). On the other hand, many households would not have the necessary capital for their downpayment for a mortgage without the non-refundable housing allocation. Thus, the latter is practically often used as a tool for capitalising otherwise not creditworthy households. This complementarity is well observed in the current situation, where a new wave of housing subsidies (this time called the "allocation for the home creation of families"; családok otthonteremtési kedvezménye, or CSOK) was introduced at the beginning of 2016 in a context of historically low interest rates, and coupled with an impressive decrease (from 27 to 5\%) of VAT on new housing construction. Currently, 80\% of households receiving CSOK also have a mortgage: thus, although the family-based housing subsidy is framed as an instrument supporting deserving, employed, childbearing Hungarian families, it actually becomes a tool catalysing further household indebtedness. ${ }^{4}$ Furthermore, the current housing subsidy (CSOK) has a few notable changes compared to its predecessor (szocpol) that orient it even more towards new construction and towards households of higher social status. The latter can be achieved by cancelling the maximum value of real estate the subsidy can be used for, as well as through stricter employment and income criteria for the beneficiaries. As a result, the circle of households who can access this subsidy is narrower. ${ }^{5}$ A project done by an NGO working in a poor and segregated Roma community demonstrated how families living in housing poverty have no possibility to benefit from this housing allocation. ${ }^{6}$

In the liberal facet of Hungarian housing policy, the government claims that it does not wish to intervene in or "distort" market processes, ${ }^{7}$ and strongly relies on an agenda of privatising risks, costs and also operative management of housing provision. This privatisation of housing provision goes two ways: primarily, it means a strong reliance 
on individual resources of households (the notion of "self-reliance" or "self-care"-öngondoskodás is absolutely central in government communication) through intergenerational transfers, private individual construction and individual indebtedness. ${ }^{8}$ The other aspect of privatised housing provision is to economic actors. The role of economic actors, mainly banks involved in housing finance, is crucial from the conception to the implementation of housing policy. Since the above-described instruments are individually allocated financial transfers, financial institutions have become front-desk operators of housing policy in Hungary. This means that their role is crucial in consultation processes leading up to the definition of policies, and also that they are the institutions managing the implementation of housing policy. This strategy of privatising implementation is particularly important for Hungarian decisionmakers, who-in line with the liberal idea of self-reliance-do not wish to sustain a public apparatus in this sector. ${ }^{9}$

This neoliberal housing policy, which dominantly relies on a creditbased access to homeownership, is inherently polarising both socially and spatially. A credit-based housing finance system necessarily benefits households that have a higher wealth and income status. In their case a mortgage can act as an effective means of leverage in the process of individual wealth accumulation. This becomes particularly important in the context of a society where inheritance and inter-generational transfers play a crucial role in access to housing. Credit lending policies of financial institutions are constructed in a way to favour clients with more reliable economic indicators, thus better-off households will receive credit with much better underwriting criteria. ${ }^{10}$ Policy instruments focusing on subsidising the cost of credit are thus disproportionally channelled to middle-class households (Hegedüs 2006) and to economically more prosperous geographical areas. A housing finance system based on individual credit (and additionally channelling state subsidies into property acquisition without any concern for affordability) will necessarily be translated into house price hikes very quickly. Current house price increases mainly affect core urban housing markets, which are already under pressure, reinforcing existing spatial unevenness. 
The selectivity of credit distribution is also true in a spatial sense; meaning that it is more difficult to secure external financing for housing in smaller or economically worse off localities. The spatial patterns of the Hungarian housing market in the past three decades have largely been determined by the mortgage lending policies of financial institutions. The dominant tendencies can be grasped by the dual, polarising terms of financial overinclusion and redlining (Aalbers 2008). These notions allow us to grasp the dual pattern of homogenisation and differentiation inherent to uneven spatial development. The former is a pattern of including social and geographical entities which were previously excluded from financial services. However, in the mid-and long term, this inclusion also creates the vehicle which allows for the extraction of resources from these more peripheral/marginal spaces and social groups. Consequently, a new wave of spatial (known as redlining) and social exclusion follows, as a strategy of risk management for the stakeholders involved in the process. The geography of overinclusion and redlining largely overlap (Aalbers 2008). The story of Hungarian mortgage lending is well described in this logic. In the period preceding the financial crisis, mortgage lending rapidly rolled out in Hungary as the main tool of access to housing. This was supported by the two main policy instruments we identify as constituting the liberal facet of Hungarian housing policy: family-based housing allocation and the state-subsidised mortgage programme. From 2000 to roughly 2008-2010 ever broader social and spatial segments were included in mortgage lending. The market incentives of financial institutions, the social need generated by the lack of other channels of access to housing, and the progressively relaxed criteria for access to state subsidies reinforced each other in this process. During this period, mortgages were granted to households with weaker repayment capacities, or in localities that later proved to be immobile in terms of housing market activity. When the financial crisis hit Hungary, a social crisis of over-indebtedness, as well as a geography of financial overinclusion emerged (Bohle 2013). 
What we call the geography of financial overinclusion are the areas where housing markets were most direly affected by the financial crisis. These are areas where house prices dropped the most significantly and default on mortgage payments represented a serious social issue. In these areas housing markets are — up until today-dominated by the sale of properties serving as collateral for non-performing mortgages. ${ }^{11}$ Following the crisis, banks in Hungary introduced much stricter redlining policies, excluding certain geographical localities from their mortgage lending. Although this would need further empirical investigation, our initial analysis suggests that the geography of previous financial overinclusion and post-crisis geographies of redlining largely overlap. ${ }^{12}$ This is also a consequence of the fact that redlining lists are (among other things) constructed based on employment and housing transaction statistics.

How does this geography of mortgage lending link up to the housing policy instruments described above? According to data provided by one of the most important banks in Hungary, the housing allocation provided to families (szocpol) was proportionally much more important in villages and smaller cities in the years before the crisis. ${ }^{13}$ Currently, after one and a half years of the "new" type of family housing allocation (CSOK; introduced in early 2016) we can say that the narrower socio-spatial focus of the current subsidy is clear compared to the pre-crisis period: villages are now receiving much less of this allocation, and the main beneficiaries are "intermediary" urban areas that have somewhat lower house prices. ${ }^{14}$

We can broadly identify (mainly based on evidence from interviews conducted with housing market actors in various locations) three typical geographies produced by Hungarian liberal housing policies. On the one hand, the core (most central) areas are the ones where capital (both mortgages and state subsidies) is concentrated in periods of crisis, and which are the primary beneficiaries of re-launching the housing market. The controversy is that these areas would have prospering housing market activity even without any state subsidies. However, since these subsidies are not tied to any income restrictions, nor are they spatially targeted, eligible households often use them in these "core" locations as a supplement to their investment. 
Secondly, the areas which are the most affected by government housing policies and where non-refundable subsidies used to access homeownership have the strongest effect are the spaces which we coin as the "peripheries of cores". Concretely, these mean the immediate agglomeration area of Budapest, or major secondary cities and their immediate outskirts. These are places which are not excluded by banks' redlining policies, and where households can strike a manageable balance between housing affordability and access to employment. In these areas, the proportion of households benefiting from the non-refundable housing subsidies is extremely high (in some places $80-90 \%$ of all transactions). Often, these households would not have sufficient savings to acquire a mortgage without the state subsidy. Thus, liberal housing policies have the most direct effect on these "intermediary" housing markets. Furthermore, these are the spaces where subsequent waves of government housing policy have left their trace in a superimposed way, and which become key areas for housing mobility and geographical mobility as well. For instance, families acquiring property in the suburbs of certain major second-tier cities (e.g. Debrecen) during the mortgage boom of the early 2000s can now often benefit from the new housing allocation in their own trajectory of housing mobility, investing in the centre of the city. Housing markets of specific cities or agglomeration areas (e.g. the immediate eastern suburbs of Budapest) where the majority of housing transactions were previously realised with cheap mortgages (either subsidised or foreign currency mortgages) are also currently being mobilised by the new wave of public subsidies after years of immobility.

The third geography we identify is that of peripheralised housing markets. These are places which may have shown some housing market activity in the most expansive phase of mortgage lending, but which experienced dropping house prices and a completely frozen housing market in recent years. In these areas house prices are so low that the family-based housing subsidy can be sufficient in itself for buying property, often pushing non-creditworthy households to buy here. Before the crisis this was a quite widespread practice and led to situations of segregation and blocked mobility (families being trapped in the bad quality housing they could acquire this way), increasing socio-spatial unevenness. Currently, due to stricter rules of access, this usage of the subsidy 
is less common/not possible on a wide scale. Furthermore, within these peripheralised spaces there are also certain localities (most notably small villages of the eastern and southern peripheries) which have been continuously declining since the early 1990s. The spatial marginality produced by structural processes of economic transformation has been reinforced by the above-described processes of the housing market.

Since 2010, the government has introduced a number of measures aimed at handling the social and economic crisis of defaulting mortgages. As a result, access to credit has become much more restricted (both socially and spatially), and the housing market is becoming even more unequal. Having "learned the lesson" that financial overinclusion induces crisis, there was an aggressive political discourse of anti-liberalism and stricter regulation in relation to housing finance between 2010 and 2015. However, it is important to see how this anti-liberalism remains to be a political rhetoric, since the fundamental elements of a financialised housing regime are currently being quite efficiently reconstructed. From 2015 onwards, the previous family-based housing allocation was rebranded as "CSOK" and mortgage lending started to be promoted again. The discourse supporting this new rollout of the same liberal housing finance system is that this time house price increases are supported by economic growth, mortgage lending is prudent and regulated, and the housing market is experiencing a healthy recovery, without any bubbles bursting. All actors are aiming to prove that they will not commit the same "mistake" again. However, looking at the socio-economic reality behind this political narrative shows that it is fragile from several points of view. At the moment housing finance institutions can profitably function while targeting only a more restricted pool of customers. In the meantime, no other, radically different housing finance instruments have been introduced, there is thus an increasing share of Hungarian society who simply do not have access to any channels of housing finance. This will likely result in increasing social pressure generated from below, which will meet the financial institutions' incentive for market expansion once their current market is saturated. In the absence of other policy measures, this could lead to similar patterns of financial overinclusion as before the crisis (if current regulations are relaxed in response to these pressures). A further limitation is that household savings currently being 
channelled into housing will diminish if there is no significant increase in wage levels (which could lead to increased savings). This, along with the persistent lack of long-term financial resources in the Hungarian banking sector (Gál 2014), means that in the long term, financial resources for this model of privatised housing provision risk drying up-both on a household and on a corporate scale. Thus, although the declared objectives of these liberal housing policy instruments are demographic and economic growth, we can see how the socio-spatial unevenness produced as a consequence is not incidental, but incremental to this policy approach to housing.

\section{The Social Facet of Housing Policy}

Even though the dominant, albeit not necessarily explicit principle of Hungarian housing policy is a primarily liberal one, it has always been coupled with a social facet, which supposedly had to manage the negative consequences of uneven development. From a spatial perspective the function of the social facet has been to contain the tensions in those marginal and peripheral spaces, which are never reached by liberal interventions. Within this supposedly socially sensitive domain of housing interventions we can differentiate between two different types of institutional logics. One (1) is the logic of the ever more paternalising welfare benefits connected to housing-related problems, while the other (2) is the "project society" (Sampson 2002) logic of territorially focused, integrated interventions. While the former logic is the product of regime change, the latter is shaped by the Europeanisation of Hungary: the emergence of the idea of "integrated social urban rehabilitations" is tightly connected to Western European impacts and to the mainstreaming of urban policy within the EU (cf. Piattoni and Polverari 2016, 413-26). Moreover, and probably more importantly, such territorially focused and supposedly socially sensitive public investments are funded almost exclusively by the Structural Funds of the European Union. Thus when analysing the social facet of fragmented housing policies in Hungary, we should pay attention to the functional interconnection and the changing relation of these two types of logics. 
The welfare type of intervention was codified in 1993 by the new Act on Social Policy. The basic logic of this intervention-called "housing maintenance benefit" (lakásfenntartási támogatás)—was that local governments could support those families that have housing-related difficulties. The exact amount and the details of targeting were determined by local governments, but research has shown that generally these benefits did not necessarily reach either socially or spatially the poorest households (Misetics 2017; Havasi 2005, 77). Even if they reached people living in housing poverty, the amount of the benefit was extremely low (Misetics 2013). In 2004 there was a reform, and the amount of the benefit was nominally doubled (in real terms the average amount of the benefit did not change substantially between 1995 and 2014). At its peak, around 2011, more than half a million households got this benefit, but its average amount was no more than 15 EUR (Misetics 2013).

All in all, the "housing maintenance benefit" was neither a political priority, nor an effective policy tool. For example in 2009 the government spent 17.7 billion HUF on them, while they spent 10 times as much on measures supporting homeownership (Misetics 2013, 52). In sum, housing benefits followed a similar logic to welfare benefits in general after 1989. Instead of helping to ameliorate poverty and decrease polarisation that were catalysed by the liberalising reforms of the 1990s, they solidified the boundaries of a sort of "welfare prison", in which poor people are trapped and controlled by welfare institutions, instead of being helped to live in dignity (Szalai 2007). As Szalai states, a deeply divided institutional framework emerged, where on the one side there were non-supported citizens successful in the liberal market processes, and on the other side there were the needy who had fallen into the trap of the ghettoised welfare sub-system. Both socially and spatially the dualisation of society-into the well-off and poor groups-was probably slightly slowed down by benefits similar to housing maintenance benefit, but definitely not stopped. The proof of this is the emergence of segregated large-scale rural spaces (Virág 2010) and pockets of urban poverty (Ladányi 2008; Ladányi and Virág 2009) in the post-1989 period, where people live in segregation, in very bad quality buildings and without the hope of entering the world of formal labour. 
Moreover, after the landslide victory of right-wing Fidesz in 2010, resulting in the party's constitutional majority in parliament, the situation got even worse for poor people. A recently published overview of social policies in Hungary showed that since 2010-for the first time in the post-1989 history of Hungary-a coherent social vision has been carried out, which systematically contributes to the social and spatial polarisation of society (Ferge 2017). Fidesz explicitly supports the shift from welfare to workfare, which meant for example the suspension of centrally financed "housing maintenance benefits" (Misetics 2017). Now it is up to local governments whether they allocate resources for such issues or not-and it seems that this worsened the situation of those living in housing poverty (Kováts 2016). ${ }^{15}$ The criteria for allocating the benefit again is up to local governments, and may contain elements such as "a clean and orderly living environment", which results in growing dependence and exposure of the needy to the local authorities. Local politicians, street-level bureaucrats and social workers became those proxy actors, who on the one hand suffer-both professionally and personally - from austerity measures that characterise the shift from welfare to workfare, and on the other hand manage and contain the frustration of citizens trapped in poverty. Amidst a general societal crisis the housing crisis is deepening (Udvarhelyi 2014), and geographical unevenness is on the rise (Koós and Virág 2010), while the only centrally allocated housing-related benefit targeting people living in poverty was suspended.

At the same time, from the early 2000s another type of intervention into housing took shape: EU-funded territorial investments. The logic of these types of investments has been to delineate an "action area" and to concentrate various types of resources within an intensive project. The keyword for such projects is that the interventions must be "integrated". This means that various types of activities should be mixed, most notably hard and soft elements. In other words, infrastructural interventions (renovating residential buildings or flats, renewing public spaces or public buildings, building communal spaces, etc.) should be mixed with social and educational interventions (vocational training, intensive social work, supporting job finding, childcare, crime prevention, 
health-related programmes, etc.). Geographically all these interventions must be carried out in an "action area", which supposedly secures complex treatment of the complex problems identified during planning. In order to delineate an action area, it must fulfil certain statistical criteria: the segregation index should be above a certain value. Currently the segregation index is the proportion of people without a formal wage and who had undergone maximum primary education in the 15- to 59-yearold population of a given territory, and a territory counts as a "segregated area" if this index is above 35\%. According to a recent study $3 \%$ of the population of Hungary, ca. 300,000 people, live in such segregated residential areas (Koltai 2014, 52).60\% of these areas are in small settlements, the remaining $40 \%$ are in cities, but only $2 \%$ of them are in Budapest (Domokos and Herczeg 2010, 89); thus unlike in Western Europe, these segregated slums are dominantly located in rural settings.

Between 2007 and 2013 ca. 195 billion HUF (667 million EUR in 2013 prices) were jointly allocated for territorially focused interventions in Hungary, which is almost the same amount that the government spent yearly in this period on liberal housing related measures. However, this amount was divided into three main types of activities for dozens of different causes during the programming period: "function enhancing urban rehabilitation" (140 billion HUF), "social urban rehabilitation" (48 billion HUF) and "slum elimination" projects (ca. 11 billion HUF) (Koltai 2014; Terra Studió Kft. 2017). The first of these lies outside the scope of this chapter, as it focused on urban centres, without any social criteria. However, taking into account the experience of similar projects before 2007, it is very likely that these projects contributed to gentrification and displacement in urban downtowns (Nagy and Timár 2007; Somogyi et al. 2007), and thus generally they also contributed to the production of unevenness.

The second, "social urban rehabilitation" was introduced in order to prevent the negative social effects of rehabilitation-induced displacement and polarisation. Only segregated areas could be delineated as action areas, and there were dozens of projects in this period in locations where formerly no public investment took place for decades. While this could be a progressive step against uneven development, it seems that many projects were controversial in spite of their 
explicit socially sensitive framing. One type of controversy is rooted in the project logic of these interventions: local governments often suspend the management of activities after the project is closed, because their lack of commitment to the goals of projects makes them see these investments as "financially unsustainable". As the bottom line of social urban rehabilitations would be to provide complex social services and physical upgrading for mid- or long-term periods, often the rapid abandonment of activities results in the disillusionment of the residents. Another type of controversy is induced by the structural situation of local governments, who are the official beneficiaries of these projects. As in many cases they suffer from insufficient central governmental subsidies and consequently from an unsustainable fiscal situation, they try to capitalise on every incoming financial resource. This frequently means attempting to "tick the necessary boxes" needed for EU funds, and then spending the money on other types of activities than the ones which would genuinely help people in marginalised situations. There were examples of renovating churches, which were not frequently visited by the locally less well off, as "communal" infrastructure projects, instead of renovating nearby social housing units without basic amenities. A third type of controversy may be that even though the interventions help a few dozen families materially, the spillover effect of the project catalyses a process of gentrification, that in turn prices out poor people from the territory. This is what happened in one of the showcase social urban rehabilitation projects in the 8th District of Budapest (Czirfusz et al. 2015). A fourth type of controversy is connected to spatially targeting these interventions. As delineation is done by the local government, there is room to manoeuvre to decide which segregated area will benefit from the projects. Unfortunately, the selection criteria were often out of line with the social sensitivity of the tenders; in other words, the principle of targeting was not based on the needs of the residents, but on other - mainly politicalfactors. For example, in one case the selection of the action area out of ten existing segregated areas was done by the local mayor based on which of these interventions would be the most popular for the local middle classes (and result in potentially more votes in the next election). 
Thirdly, slum elimination - with a total budget of 12 billion HUFwas introduced at the end of the 2007-2013 programming period. This focused on both segregated areas and slums, but had a more crystallised philosophy. Local governments had to form a consortium with a nation-wide public institution and with an NGO in order to upgrade physically and socially the segregated slums. Instead of desegregating (i.e. demolishing the buildings and relocating the residents to "integrated" neighbourhoods) the projects aimed to keep the residents in place and provide social services locally with the continuous presence of social workers. This philosophy was criticised by various professionals and was nicknamed "beautifying the ghettos", mainly because the roots of the problems (i.e. the structural factors leading to the systematic production of marginalised territories) were not targeted, only the most basic needs of the residents (installing a place to wash their clothes and to have a shower, etc.). From another point of view, these projects also had a controlling, regulating function: many times CCTV cameras were installed, while little assistance was given to ease the burden on household budgets and similar needs. No doubt such support, though small, helped households, nevertheless, it would be hard to depict slum elimination projects as a systemic answer to the production of unevenness.

All in all, the effectiveness of the programmes that we identified as constituents of the social facet of housing intervention is at the least questionable. The logic of welfare types of benefits contributed to the institutional dualisation of Hungarian society, not to speak of the relative fiscal insignificance of such public subsidies compared to liberal interventions. Furthermore, with the recent shift from welfare to workfare, this hidden dualising effect became explicit. For example János Lázár, who is now the minister responsible for supervising all EU-funded investment activities, stated in 2011 that "who has nothing is worth nothing" (Index.hu 2011). At the same time, while the rhetoric of emerging logic-based EU-funded projects ran counter to the housing-related liberal principles of the government, their effects cannot systematically counteract the dualisation caused by all the other public interventions. Moreover, with the inflow of such transfers, the government was able to fiscally back out from the support of people affected by housing poverty. 


\section{Conclusion}

The aim of this chapter was to analyse housing-related governmental interventions in Hungary within a holistic framework. Even though since 1989 housing has been governed in a fragmented institutional environment by allocating various functions to different public and private institutions, we believe that there is a certain systematic logic behind institutional fragmentation, which results in the (re)production of socio-spatial unevenness.

Our chapter is a contribution to the recently expanding body of literature in economic geography, which aims to understand how uneven development unfolds in various ways under financial capitalism. Furthermore, it is a contribution to the political economic understanding of housing policy interventions (also strongly relating to the notion of housing financialisation). Although these conceptual approaches usually build their arguments based on empirical material from Western European and Anglo-Saxon cases, we believe it is important to balance this bias and give theoretical arguments from the position of non-core social realities. In our understanding this is an essential step to engaging with issues like regional and local development, and especially their relation to polarising tendencies in different contemporary post-crisis settings.

In Hungary, the liberal facet of housing policy receives significantly more budgetary resources than interventions in the social facet of housing policy. Since its declared aims are demographic and economic growth, it is not at all concerned with socio-spatial equity. Furthermore, while the former is a generalised, nationally implemented policy, the latter measures are often spatially localised and financially dependent on local municipalities (struggling with a constant lack of resources). Thus they are inherently uneven and are not able to do more than intervene on a small scale in situations of marginalised housing. This is similar to how general welfare instruments developed in the 1990s, which in the end had the effect of enclosing recipients in an enclave of povertyboth societally and spatially (Szalai 2007).

The liberal facet of housing policies is dominant in Hungary, with mortgage-based individual homeownership being the only form of housing tenure supported by the government. The two main policy 
instruments of this housing regime are a non-refundable government subsidy allocated according to the number of children in a family, and subsidised mortgages. Although these policies are not articulated in a spatial way and claim to generally benefit households across the whole social spectrum, we have seen that in fact they implicitly reproduce socio-spatial unevenness. Social polarisation is the result of a fundamentally credit-based housing finance system, which necessarily favours better-off households. The non-refundable housing allocation serves as a means of leveraging credit in $80 \%$ of the cases, and thus only facilitates access to further mortgage debt for a specific, selected pool of households. This_-along with the fact that housing-related subsidies for housing acquisition are managed by banks_-places a major part of the entire Hungarian housing finance system under the institutional logic of financial institutions. This logic-especially in the aftermath of the global financial crisis - is one of increased risk management, leading to more social and spatial selectivity. As a result, the uneven spatial structure of the Hungarian housing market is reinforced.

At the other end of the spectrum of housing-related interventions, the most symbolic policy instruments aiming to target poorer households are the housing maintenance benefit, which follows the logic of welfare benefits, and various tools used in integrated territorial development, which follow the logic of project society. While housing-related benefits are socially but not spatially targeted, they are delegated to local municipalities (similarly to the management of the very small remaining public housing stock), but through the lack of national-scale engagement reproduce spatial unevenness. On the other hand, territorially focused, supposedly "social" urban rehabilitation policies targeting the less well off inhabitants of social housing units are a very clearly spatially articulated set of policies. These latter policies are financed by territorial operational programmes within the national financing mechanisms for distributing European Union cohesion funds. The fact that investment in public housing practically only happens when EU funds can be used for this purpose already demonstrates the low priority of this issue in Hungarian policy-making. We do not claim that intervention in the housing situation of marginalised groups would necessarily produce further unevenness in general. But these spatially localised interventions in 
the dilapidated public housing stock do not give systemic responses to the socio-spatial inequalities produced by the dominant housing regime, and often induce further processes of marginalisation.

Altogether, there is a growing segment of Hungarian society that is not reached by either the liberal or the social facets of housing policy. As for liberal side of housing policies, many households do not fit into the stricter mortgage lending criteria put in place after the crisis or the politically preferred family model, which grants access to non-refundable subsidies. Thus, many households will not be able to access homeownership, and will have to solve their housing problems by other means. Within the social facet of housing policies, there is a tendency to continuously narrow the scope of these interventions. Local municipalities are constantly diminishing their housing stock, and-in the context of a complete lack of central government funding for these purposes-are aiming to limit all housing-related budgetary expenditures. As a result, more and more households find themselves outside the scope of housing policies-both liberal and social. They do not have access to individual, mortgage-based homeownership or to an increasingly restricted social housing stock. In this widening gap between the two ends of the currently existing housing policy, new forms of housing provision are developing, which are mostly invisible both to research and to policy. The actors driving these new forms are individual households in need of housing, and new smaller scale market actors recognising this gap.

The best response to this situation is not a new wave of excessive mortgage lending, similar to what happened before the crisis (which would attempt to push everyone into the dominant liberal housing model). Rather, new forms of affordable housing need to be developed. It is clear that publicly owned housing in its current form cannot respond to these needs. As long as local municipalities despite lacking financial resources remain the owners of public housing units, there will always be the political will not to displace the less well off and instead provide new resources for renovation (or construction) from the European Union in a timely fashion. What is needed is state intervention either in the form of state-owned social housing, developed within the framework of a national-scale programme, or in the form of providing support to create the institutional-legal and financial preconditions 
for a new institutionalised rental housing sector. These new institutions of rental housing could range from publicly regulated housing companies to self-managed housing cooperatives, and could start filling the gap between the two extremes of current, polarising housing policies.

\section{Notes}

1. Based on interviews conducted with various Hungarian urban experts.

2. We use "liberal" here in a generic sense, referring to housing policies that generally point in the direction of privatised risks and costs of housing provision, as well as a housing model based on ownership and debt. This is what Crouch (2009) calls privatised Keynesianism, or the privatisation of risk, or what Aalbers (2017) calls a general direction of housing financialisation along different trajectories. We contrast it with the idea of "social" housing policies understood in a broad sense.

3. Interview conducted with a high-ranking public official responsible for housing-related financial instruments within the Ministry of National Economy.

4. Interview conducted with a high-ranking public official responsible for housing-related financial instruments within the Ministry of National Economy; referencing internally available statistics from the Hungarian National Bank.

5. This is confirmed by interviews conducted with various real estate agents in second-tier cities (e.g. Békéscsaba, Kecskemét, Miskolc), as well as by interviews conducted with financial institutions distributing this subsidy.

6. This was a community-led project concentrating on housing issues in Bag (a town in the eastern agglomeration area of Budapest). The website of the program is available at http://bagazs.org/mit-csinalunk/hallasd-a-hangod/; and a video about the results (this is where they address the issue of CSOK) can be viewed at https://youtu.be/zaQi2_Z0a4M.

7. Interview conducted with a high-ranking public official responsible for housing-related financial instruments within the Ministry of National Economy.

8. This element of self-care is perhaps most obviously put forward in a third important housing policy instrument: the "housing savings 
contracts" (based on the German Bausparkassen model) which are constantly increasing in size and importance.

9. Interview conducted with a high-ranking public official responsible for housing-related financial instruments within the Ministry of National Economy; interview conducted with the person responsible for mortgage lending within the largest Hungarian bank; interview conducted with representatives of the Hungarian National Bank working on issues of housing finance.

10. Interviews conducted with various financial institutions involved in mortgage lending.

11. Based on interviews conducted with real estate agents in the eastern agglomeration area of Budapest, as well as in the agglomeration area of a large city in a de-industrialised region (Miskolc).

12. This claim is made based on data provided by the largest Hungarian bank about their mortgage lending, and based on data from the Hungarian National Bank about non-performing loans. However, neither of these data sets are available on a sufficiently detailed geographical scale to be able to identify very precise overlapping geographies. The most we can claim is that an institutional and spatial tendency definitely exists that supports a causal link between the geographies of financial overinclusion and exclusion.

13. We have compared these data to the number of inhabitants in the given settlement category-but this dominance of small settlements would be even stronger if we compared the data to the number of housing transactions.

14. Based on interviews conducted with a number of real estate and loan agents from the financial institutions involved in distributing this subsidy.

15. This move, that the costs of providing social services for the less well off are put on the shoulders of local governments, while the necessary financial means are not provided centrally, fits well with the more general process in post-1989 Hungary. This process was called "decentralization without subsidiarity” by András Vigvári (2008), who described how several duties were delegated to local governments in the name of autonomy, while financial autonomy was not granted for them. Although after 2010 recentralisation replaced decentralisation as the main tendency in the relation between the central and local governments, there continue to be areas that chime with what Vigvári described. 


\section{References}

Aalbers, Manuel B. 2008. "The Financialization of Home and the Mortgage Market Crisis." Competition \& Change 12 (2): 148-66. https://doi.org/10.1 179/102452908X289802.

Aalbers, Manuel B. 2017. "The Variegated Financialization of Housing." International Journal of Urban and Regional Research 41 (4): 542-54. https://doi.org/10.1111/1468-2427.12522.

Bohle, Dorothee. 2013. "Post-Socialist Housing Meets Transnational Finance:

Foreign Banks, Mortgage Lending, and the Privatization of Welfare in Hungary and Estonia." Review of International Political Economy 21 (4): 913-48. https://doi.org/10.1080/09692290.2013.801022.

Bohle, Dorothee. 2017. "Mortgaging Europe's Periphery." LSE 'Europe in Question' Discussion Paper Series. LEQS Paper No. 124. http://www. lse.ac.uk/europeanInstitute/LEQS\%20Discussion\%20Paper\%20Series/ LEQSPaper 124.pdf.

Crouch, Colin. 2009. "Privatised Keynesianism: An Unacknowledged Policy Regime." The British Journal of Politics and International Relations 11 (3): 382-99. https://doi.org/10.1111/j.1467-856X.2009.00377.x.

Czischke, Darinka. 2009. "Managing Social Rental Housing in the EU: A Comparative Study." International Journal of Housing Policy 9 (2): 121-51. https://doi.org/10.1080/14616710902920223.

Czirfusz, Márton, Vera Horváth, Csaba Jelinek, Zsuzsanna Pósfai, and Linda Szabó. 2015. "Gentrification and Rescaling Urban Governance in Budapest-Józsefváros.” Intersections 1 (4): 55-77. https://doi.org/10.17356/ ieejsp.v1i4.104.

Domokos, Veronika, and Béla Herczeg. 2010. “Terra Incognita: Magyarországi szegény- és cigánytelepek felmérése - első eredmények.” Szociológiai Szemle 20 (3): 82-99.

Dunford, Michael, and Weidong Liu. 2017. "Uneven and Combined Development." Regional Studies 51 (1): 69-85. https://doi.org/10.1080/00 343404.2016 .1262946$.

Ferge, Zsuzsa. 2017. Magyar társadalom- és szociálpolitika 1990-2015. Budapest: Osiris.

Fernandez, Rodrigo, and Manuel B. Aalbers. 2016. "Financialization and Housing: Between Globalization and Varieties of Capitalism." Competition and Change 20 (2): 71-88. https://doi.org/10.1177/1024529415623916. 
Gál, Zoltan. 2014. "Role of Financial Sector FDI in Regional Imbalances in Central and Eastern Europe." In Eurozone Enlargement: Challenges for the V4 Countries, edited by Agata Gostyńska, Paweł Tokarski, Patryk Toporowski, and Damian Wnukowski, 19-30. Warsaw: The Polish Institute of International Affairs.

Havasi, Éva. 2005. "A transzferjövedelmek szerepe a szegénység csökkentésében.” Esély 4: 66-86.

Hegedüs, József. 2006. "Lakáspolitika és a lakáspiac - a közpolitika korlátai." Esély 5: 65-100.

Hegedüs, József, and Eszter Somogyi. 2016. "Moving from an Authoritarian State System to an Authoritarian Market System. Housing Finance Milestones in Hungary between 1979 and 2014.” In Milestones in European Housing Finance, edited by Jens Lunde and Christine Whitehead, 201-17. Oxford: Wiley-Blackwell. https://doi.org/10.1002/9781118929421.ch12.

Hudson, Ray. 2016. "Rising Powers and the Drivers of Uneven Global Development." Area Development and Policy 1 (3): 279-94. https://doi.org /10.1080/23792949.2016.1227271.

Index.hu. 2011. "Lázár szerint akinek nincs semmije, az annyit is ér.” Index.hu, 19 March. http://index.hu/belfold/2011/03/19/ lazar_szerint_akinek_nincs_semmije_az_annyit_is_er/.

Koltai, Luca. 2014. Éves jelentés a lakhatási szegénységról 2014. Budapest: Habitat for Humanity Magyarország. http://www.habitat.hu/files/ HABITAT_2014_lakhatasi_jelentes_hosszu_1109.pdf.

Koós, Bálint, and Tünde Virág. 2010. "Nyertesek és vesztesek. A magyar településhálózat polarizálódása." In A területi kutatások csomópontjai, edited by Györgyi Barta, Pál Beluszky, Zsuzsanna Földi, and Katalin Kovács, 32-54. Pécs: MTA Regionális Kutatáso Központja.

Kováts, Bence. 2016. Az önkormányzati hatáskörbe került lakhatási támogatások vizsgálata 31 önkormányzat példáján. Budapest: Habitat for Humanity Magyarország. http://www.habitat.hu/files/Onkormanyzati_lakhatasi_ tamogatasok_Habitat_0720.pdf.

Ladányi, János. 2008. Lakóhelyi Szegregáció Budapesten. Budapest: Új Mandátum Könyvkiadó.

Ladányi, János, and Tünde Virag. 2009. “A szociális és etnikai alapú lakóhelyi szegregáció változó formái Magyarországon a piacgazdasági átmenet időszakában." Kritika 7/8: 2-8. 
Misetics, Bálint. 2013. "Javaslatok egy egalitariánus lakáspolitikai reform fó irányaira: Politikai és szakpolitikai vázlat.” Esély 1: 39-73. http://www.esely. org/kiadvanyok/2013_1/misetics.pdf.

Misetics, Bálint. 2017. "Lakáspolitika és hajléktalanság." In Magyar társadalom-és szociálpolitika. 1990-2015, edited by Zsuzsa Ferge, 338-63. Budapest: Osiris.

Nagy, Erika, and Judit Timár. 2007. "A középvárosi dzsentrifikáció társadalmi hatásai a posztszocialista Magyarországon.” In A történelmi városközpontok átalakulásának társadalmi hatásai, edited by György Enyedi, 293-319. Budapest: MTA Társadalomkutató Központ.

Peck, Jamie. 2016. "Macroeconomic geographies." Area Development and Policy 1 (3): 305-22. https://doi.org/10.1080/23792949.2016.1237263.

Piattoni, Simona, and Laura Polverari, eds. 2016. Handbook on Cohesion Policy in the EU. Cheltenham: Edward Elgar.

Pósfai, Zsuzsanna, Zoltán Gál, and Erika Nagy. 2018. "Financialization and Inequalities: The Uneven Development of the Housing Market on the Eastern Periphery of Europe." In Inequality and Uneven Development in the Post-Crisis World, edited by Sebastiano Fadda and Pasquale Tridico, 167-90. Abingdon: Routledge.

Raviv, Or. 2008. "Chasing the Dragon East: Exploring the Frontiers of Western European Finance." Contemporary Politics 14 (3): 297-314. https:// doi.org/10.1080/13569770802396345.

Sampson, Steven. 2002. "Beyond Transition: Rethinking Elite Configurations in the Balkans." In Postsocialism: Ideals, Ideologies and Practices in Eurasia, edited by Chris M. Hann, 297-316. London: Routledge.

Sokol, Martin. 2013. “Towards a 'Newer' Economic Geography? Injecting Finance and Financialisation into Economic Geographies." Cambridge Journal of Regions, Economy and Society 6 (3): 501-15. https://doi. org/10.1093/cjres/rst022.

Somogyi, Eszter, Hanna Szemzo, and Iván Tosics. 2007. "Városrehabilitáció kétszintü önkormányzati rendszerben: budapesti sikerek és problémák. 1994-2006." In A történelmi városközpontok átalakulásának társadalmi hatásai, edited by György Enyedi, 69-92. Budapest: MTA Társadalomkutató Központ.

Szalai, Júlia. 2007. Nincs két ország...? Budapest: Osiris.

Terra Studió Kft. 2017. "Integrált városfejlesztések értékelése. Ex-post értékelés a 2007-13-as időszakról.” https://www.palyazat.gov.hu/download. php?objectId=71199. 
Udvarhelyi, Éva Tessza. 2014. "'If We Don't Push Homeless People Out, We Will End Up Being Pushed Out by Them': The Criminalization of Homelessness as State Strategy in Hungary." Antipode 46 (3): 816-34. https://doi.org/10.1111/anti.12068.

Vigvári, András. 2008. "Szubszidiaritás nélküli decentralizáció: Néhány adalék az önkormányzati rendszer magyar modelljének korszerűsítéséhez." Tér És Társadalom 22 (1): 141-67.

Virág, Tünde. 2010. Kirekesztve. Akadémiai Kiadó: Falusi gettók azország peremén. Budapest.

Open Access This chapter is licensed under the terms of the Creative Commons Attribution 4.0 International License (http://creativecommons. org/licenses/by/4.0/), which permits use, sharing, adaptation, distribution and reproduction in any medium or format, as long as you give appropriate credit to the original author(s) and the source, provide a link to the Creative Commons license and indicate if changes were made.

The images or other third party material in this chapter are included in the chapter's Creative Commons license, unless indicated otherwise in a credit line to the material. If material is not included in the chapter's Creative Commons license and your intended use is not permitted by statutory regulation or exceeds the permitted use, you will need to obtain permission directly from the copyright holder.

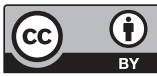




\section{Part III}

Responses to Regional Polarisation and Alternative Perspectives 


\title{
10
}

\section{Out-Migration from Peripheries: How Cumulated Individual Strategies Affect Local Development Capacities}

\author{
Aura Moldovan
}

\section{Introduction}

Over the past two and a half decades, the EU member states from Central and Eastern Europe (CEE) have transitioned from state socialism to democracy, from a centralised to a market economy. At the national level, the post-socialist transition has brought economic growth to these countries. At a regional scale however, socio-economic inequalities have developed and the gap between centres and peripheries has increased (Kurkó 2010; PoSCoPP Research Group 2015; Leibert 2015). Over the years, capital cities and regional urban centres have transitioned more successfully and have found ways to integrate themselves into global production networks. As a result of higher capital investment compared to the rest of the region, these urban centres accumulate benefits in terms of job creation, higher tax revenues, more public investments in infrastructure, and higher levels of engagement

\footnotetext{
A. Moldovan $(\bowtie)$

Faculty of Geography, Babeş-Bolyai-University, Cluj-Napoca, Romania

(C) The Author(s) 2019

T. Lang and F. Görmar (eds.), Regional and Local Development

in Times of Polarisation, New Geographies of Europe,

https://doi.org/10.1007/978-981-13-1190-1_10
} 
in a variety of political and innovation networks (Gottdiener and Budd 2005). The peripheries however have not coped as well. More secluded rural areas, mining settlements and the former mono-structural industrial regions are facing a much slower development or even decline. Left with limited access to desirable resources (material or symbolic), and with restricted room for autonomous action (Kreckel 2004), they are experiencing increasing marginalisation and peripheralisation (Pütz 1999; Surd et al. 2011; Török 2014; Benedek 2015).

With accession to the European Union, CEE countries were incentivised to adopt neoliberal competitiveness-centred policies. And despite the European Union's plea for balanced, integrated and inclusive development, its policies have favoured the increasing development of existing urban centres (Lang 2011; Fischer-Tahir and Naumann 2013). Thus, investment flows generated by advanced local and regional economic agents were mainly concentrated in urban centres and their metropolitan areas, and did not trickle down to peripheries, as traditional models of economic growth would suggest (Spoor 2013; Benedek and Moldovan 2015). In this context, it is particularly the rural areas of the post-socialist countries that have experienced increasing peripheralisation (Fischer-Tahir and Naumann 2013). This is not to say that rurality constitutes a periphery per se. On the contrary, through suburbanisation or by successfully marketing images of a rural idyll, some villages have seen intensive socio-economic development. Their share, however, is rather small, as specific conditions have to be met in terms of accessibility, the state of physical and service infrastructure, and attractiveness of tourist destinations (Keim 2006). More often, rural areas are struggling with economic and demographic issues brought on by market-driven devaluation of local assets (cheap labour, agricultural land, local skills and relations) (Nagy et al. 2015), and by fierce competition with international distributors of products once sourced from regional or national rural areas (such as food, lumber, yarn or leather) (Keim 2006). As a result, rural peripheries in CEE are among the poorest regions in the European Union (Leibert 2013).

Taking one such post-socialist rural periphery as a case study, this chapter relies on structured interviews collected in July 2017 in villages of Sălaj County in Romania (Map 1). Sălaj is mostly rural (93\% of 


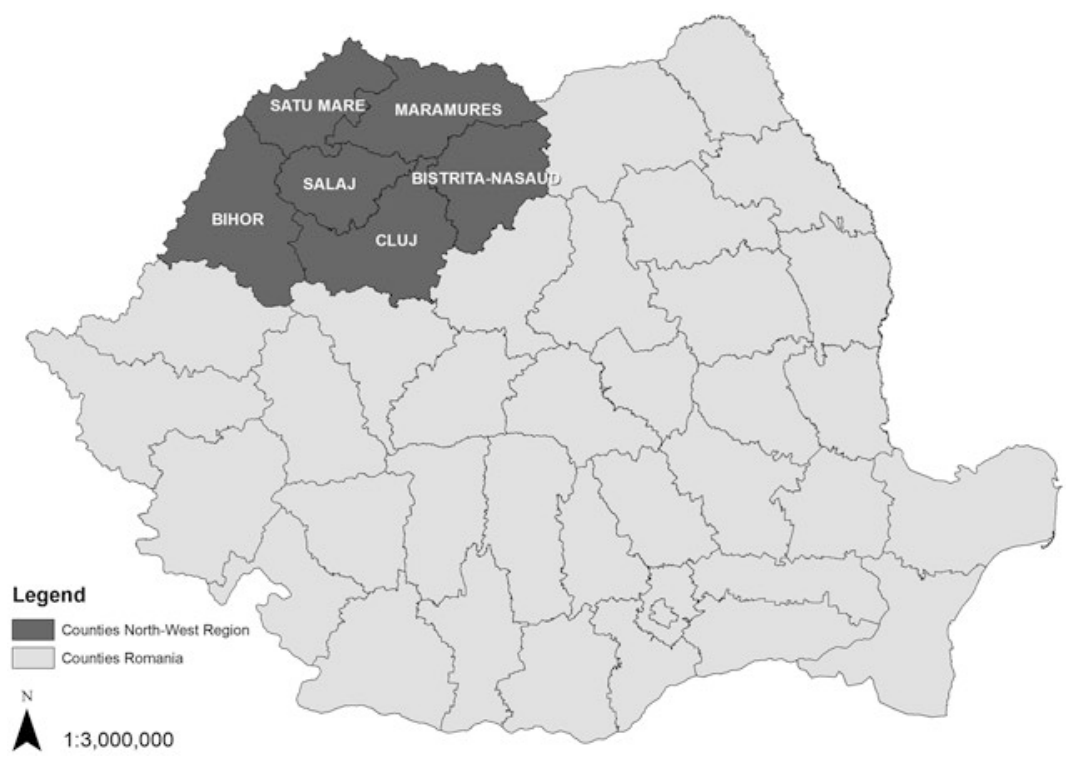

Map 1 Geographic location of the North-West Region and of Sălaj County in Romania. Source Prepared by the author

its settlements are villages and $61 \%$ of the population lives in villages, according to 2011 census data), without having (yet) developed a strong functional urban area around any of its four cities. This means that the county is mostly comprised of structurally disadvantaged villages. It is also the least developed county in terms of human, health, vital and material capital (Ionescu-Heroiu et al. 2013, 240) in one of the most polarised NUTS2 regions in Romania, the North-West Region. Here, the city of Cluj-Napoca, which is one of the main economic engines in the entire country, acts as the regional centre, while the North-West Region as a whole remains one of Romania's "lagging regions", with a GDP per capita (PPS) below 50\% of the EU average (Cristea et al. 2017, 7). As the villages in Sălaj are peripheral across various spatial scales, the case study area allows an in-depth analysis of the effects of increasing regional polarisation and peripheralisation.

Using this case study as a representation of post-socialist rural peripheries, the chapter aims to critically engage with the economic and 
demographic struggles that such peripheries are facing, specifically in relation to one of the main contributors to peripheralisation, selective out-migration (Kühn and Weck 2013; Kühn 2015; Leibert 2015). While previous studies on the topic have focused heavily on the structural factors that affect socio-spatial polarisation and peripheralisation, this chapter addresses a gap in the research by employing an actorbased approach (Fischer-Tahir and Naumann 2013; PoSCoPP Research Group 2015; Miggelbrink and Meyer 2015) (as further elaborated in Chapter 2). The selected empirics first illustrate how actors affected by peripheralisation utilise different forms of out-migration as strategies to improve their quality of life (in Sect. 3.1). The empirical findings secondly showcase the impact the cumulative mobility of these actors has on shaping local development potentials and strategies, as described by local public officials (in Sect. 3.2). Overall the analysis contributes to the debate on how local development is affected in times of polarisation, by revealing how the interdependency between peripheralisation and out-migration limits the decision-making capacity of local administrative leaders, and diminishes local development capacities in peripheral settlements even further (in Chapter 4).

\section{Peripheralisation and Selective Out- Migration: A Deepening Vicious Circle}

Recent studies examining the increasing regional polarisation in Central and Eastern Europe have focused on a more process-based and dynamic understanding of the terms "polarisation", "centralisation" and "peripheralisation". At the core of this conceptualisation lies the relation between the two interdependent types of spaces — centres (or cores) and peripheriesboth of which are continuously being re-created in relation to each other across various scales, and cannot define themselves as one or the other without referencing their counterpart (Keim 2006; Warf 2008; Bernt and Liebmann 2013; Kühn 2015; PoSCoPP Research Group 2015). Thus, peripheralisation can be described as a process in which peripheries experience a gradual and persisting decline in socio-spatial development, as well as a long-lasting solidification of structural deficits in relation to 
a dominant centre, which widens the disparities between them (Keim 2006). Such peripheries are faced with relatively low income, a low level of education, low quality occupation (e.g. subsistence agriculture or lowskilled jobs) (following Kreckel 2004), demographic shrinkage, ageing, and the out-migration of young, highly-educated people (following Kühn 2015). These deficits translate into institutional thinness and a limited capacity of the peripheral space to secure a high quality of life for its population, and implicitly cause a growing dependence on the centre (Keim 2006; PoSCoPP Research Group 2015).

As a process, selective emigration is one of the main contributors to increasing peripheralisation, along with decoupling, dependency and stigmatisation (Kühn and Weck 2013,40). On the one hand, the existence of strong emigration flows among young and skilled adults can be seen as a consequence of peripheralisation, as it indicates an existing lack of educational facilities, reduced availability for highly skilled employment, as well as an existing stigma regarding future perspectives (Bernt and Liebmann 2013; Leibert 2015). But at the same time, this brain drain (and the implicit demographic shrinkage that it accompanies) is also a cause for further peripheralisation. Not only does the decreasing share of the active population reduce the amount of local taxes and incomes, thus diminishing the ability of the local municipality to maintain or modernise social and physical infrastructures, but also the emigration of skilled professionals reduces the local capacity for innovation (Bernt and Liebmann 2013). Overall, out-migration and shrinkage negatively influence the level of sustainability for existing local economies, the prospects of new economic projects, as well as the overall quality of life. Ultimately, this encourages future waves of out-migration and leads to a vicious circle that reproduces peripherality (Massey 1990).

While much of the existing literature investigates spatial disparities and the interdependence between out-migration and peripheralisation in terms of the participating structural processes, recent scholarship is also arguing for complementing this socio-structural focus with a more actor-based approach, noting the existing gaps in research regarding both the actors causing peripheralisation and the actors affected by it (Fischer-Tahir and Naumann 2013; PoSCoPP Research Group 2015; Miggelbrink and Meyer 2015). At the structural level, peripheralisation 
is linked to demographic shrinkage and ageing, to selective outmigration and a lack of in-migration, and to low income and low-quality occupation (Kreckel 2004; Bernt and Liebmann 2013; Kühn 2015). But behind the major flows of migration, there is a sum of active individuals who are reacting to core-periphery relations by moving - albeit in the same direction. Or, as Bernt and Liebmann $(2013,219-20)$ put it, by leaving the periphery, emigrants are "voting with their feet" to express the perceived lack of perspectives for the future in their hometowns. In this sense, from an actor-centred position, migration is a way for individuals to place themselves in a preferred living environment, depending on the needs and the possibilities that they and their families have.

But what causes someone to migrate? Recent scholarship shows that the decision is never simple, nor is it taken in a completely rational and optimising way. Instead, the decision is complex, taken because of multiple reasons, in relation to a person's social network. It is located within their individual biography, connected to all the macro-structures that have shaped their identity, as well as to personal life experiences, and entangled with their future aspirations (Boyle et al. 1998). This focus on agency shows that people engaged in migration are actively concerned with re-placing themselves in a preferred living environment, which they perceive as having a higher quality of life and greater chances for their and their families' well-being (ibid.). As this can mean different things to different people, mobility is shown to be an extremely cultural event (Fielding 1992) that can reveal personal values and attachments, and the entire world-view of those choosing to migrate. With the cultural character of migration transpiring, it becomes an example of behaviour, rather than a simple action. It becomes part of the person's identity, an "expression of people's sense of being at any one point in time” (Gutting 1996, 482).

With the composition and direction of mobility flows affecting coreperiphery relations at the structural level (see also Moldovan 2017), an actor-centred analysis can help identify how the interplay of core-periphery relations has triggered out-migration as a mechanism of coping with peripheralisation, while also suggesting potential strategies and policies that could combat peripheralisation. The following empirical material aims to achieve just that. Firstly, the main individual narratives and lines of reasoning behind emigrating are used to identify the most pressing structural deficits 
that peripheries are struggling with. Secondly, the narratives of public officials trying to increase local development reveal what strategies and policy tools peripheries are already employing and what is still lacking in order to decrease core-periphery inequalities.

\section{$3 \quad$ Taking Individual Mobility Decisions from the Periphery}

One of the drawbacks of the relational conceptualisation of peripheralisation is that it leaves unclear how to empirically identify peripheries (Bernt and Liebmann 2013; Kühn 2015). In order to avoid a physicalspatial bias, the first step taken in the selection of the twelve villages in which the fieldwork was conducted was based on quantitative data, to show a lower level of local development in terms of human, health, vital and material capital. ${ }^{1}$ In the second step, ten of the twelve villages were selected as a case study area for the present analysis (Map 2), based on whether the subjective perceptions of local political leaders

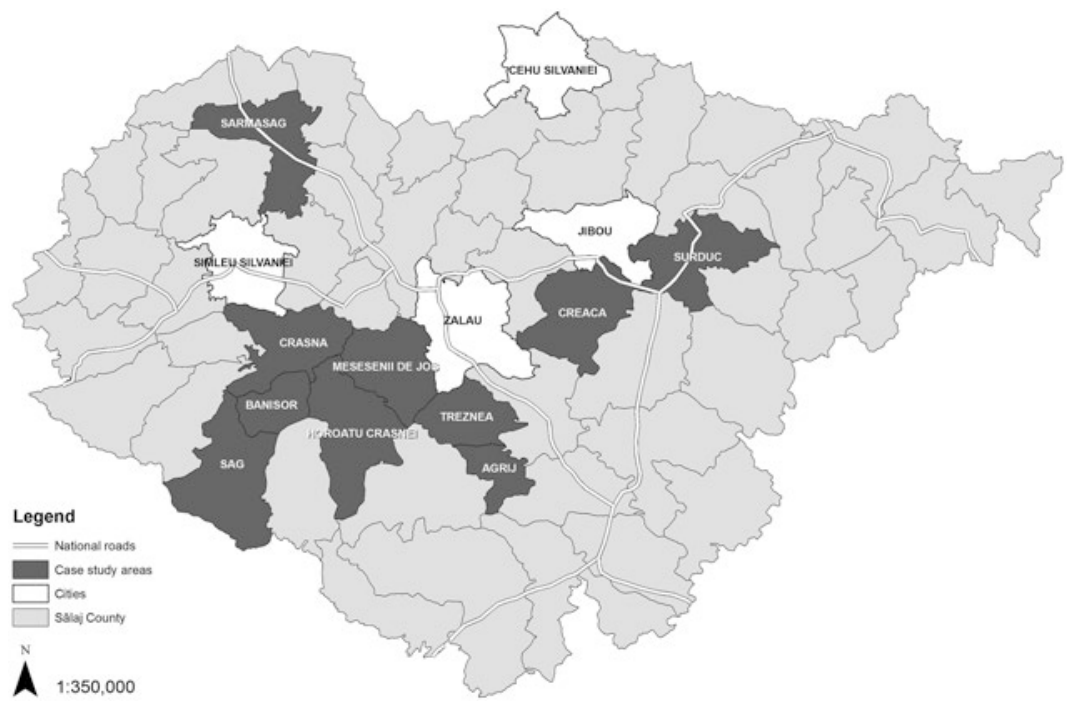

Map 2 Case study area: ten peripheral villages in Sălaj County. Source Prepared by the author 
and administrative workers fit the conceptual description of "peripheralisation". In the end, all ten villages (ranging in size from 1041 to 6710 inhabitants) share the following characteristics, albeit to various degrees: their population earn their main sources of income from low quality occupations (agriculture or low-skilled jobs), they lack physical infrastructure and facilities for higher education (only four of the villages have their own high school and vocational school, and the results of their students are quite poor), and they were described as struggling with population shrinkage and ageing, and with the out-migration of young adults. ${ }^{2}$ Outmigrants predominately move either to nearby cores to enrol in university courses and pursue highly-skilled occupations, or engage in temporary and circular migration abroad, if they occupy lower skilled professions.

To show how out-migration is employed as a strategy to cope with or to overcome peripheralisation and how cumulated individual decisions affect local development capacities, this chapter draws on a total of 28 semi-structured interviews with local public officials, and 134 structured interviews with locals from 10 peripheralised settlements of Sălaj County (Table 1). ${ }^{3}$ The first set of interviews was conducted with local

Table 1 The number of interviews conducted in the case study area

\begin{tabular}{lcc}
\hline Name of settlement & $\begin{array}{l}\text { Interviews with public } \\
\text { officials }^{\text {a }}\end{array}$ & $\begin{array}{l}\text { Interviews with local } \\
\text { inhabitants }\end{array}$ \\
\hline Agrij & 3 & 9 \\
Bănișor & 3 & 15 \\
Crasna & 3 & 15 \\
Creaca & 4 & 15 \\
Horoatu Crasnei & 2 & 12 \\
Meseșenii de Jos & 2 & 12 \\
Sărmășag & 3 & 15 \\
Sâg & 3 & 15 \\
Surduc & 3 & 15 \\
Treznea & 2 & 11 \\
Total & 28 & 134 \\
\hline
\end{tabular}

Source Prepared by the author

aln order to protect the anonymity of the public officials who agreed to the interviews, the present analysis lists the sources for relevant quotes by mentioning the respondent's occupation, but not the village of origin. Instead, each village has been assigned a random number from one to ten, in a non-alphabetical order 
political leaders and administrative workers, holding one of the following positions: mayor, deputy mayor, secretary of the mayor's office, ${ }^{4}$ social worker, official in charge of the agricultural registry, school secretary and accountant. These interviews sought to bring forth descriptions of the overall local socio-economic context, looking into the main issues that each village is struggling with as well as the strategies employed for local development. The second set of interviews was conducted with adult local inhabitants, who were presently employed or had been in the past. They were asked about their own occupational history, their personal experience with migration or commuting, and their future aspirations. In order to capture the complexity and the embeddedness of the decision to become mobile, these interviews also enquired about the status of other household members and how they all managed their everyday lives together, aiming to show how the interest of the entire family was considered when making occupational choices. In this way, the discussions were also marked by those who were absent, especially through stories of children who moved away, so that the interviews also highlighted aspects of long-term emigration.

\subsection{Local Strategies Employed by Individuals to Cope with Peripheralisation}

In the case study area, agriculture is the main economic activity of the inhabitants. Even if the interviews systematically excluded individuals living on subsistence agriculture (as this is not a form of employment and also not an occupation favouring territorial mobility), most respondents revealed that besides the various jobs they held, they cultivate patches of land and rear animals, in order to produce household products for their own consumption. Respondents who were employed in the settlement of residence mostly worked as labourers in one of the smaller shops or workshops, or held positions in the public sector. Salaries were often described as modest and the lack of jobs deemed more suitable in the home village was a commonly mentioned issue. Consequently, many locals have been looking for job offers elsewhere. Following the occupational history of the respondents, 
the interviews with locals reveal that they engage in four types of mobility in order to improve their situation: commuting, internal migration, international migration and temporary migration abroad. Choosing one of these mobilities is deeply connected to the actors' identity, aspirations, possibilities and attachments, and the choice reveals which structural disadvantages affect them the most. In this sense, each type of mobility represents a strategy to cope with the different effects of peripheralisation.

A first strategy employed is commuting to a town nearby. In fact, most respondents had themselves experienced commuting, either presently or in the past, or at least one of their family members had commuted for work. Mostly they or their family members commuted for low-skilled employment in industry or in services and trade. However, the interviews reveal a generational shift in the attitude towards commuting: while during the socialist period commuting to one of the large industrial sites was common practice, nowadays it is the middle aged or older adults who still commute. For them, commuting offers access to a wider labour market, while also allowing them to remain in the homes that they have built in the village. In their narratives, they often contrast living in the village, in a house with a small garden, to living in the city, in a flat. Moreover, living in an apartment would deprive them of the additional income they get from subsistence agriculture, but it would also take them away from the rural lifestyle, which they perceive to be calmer, healthier and safer than the urban one. Their attitude can be summed up by this respondent:

I cannot move to Zalău if I grew up in the village, I don't like blocks of flats. The kids can go, if they want to, but I can't. (interview, Male, aged 45, Bănişor, July 2017)

Younger generations, however, seem to have their preferences reversed and favour migration over commuting. Since they are not living in the villages anymore, their stories were told by the parents or siblings left behind. And the story of internal migration starts with the local educational infrastructure. All analysed settlements have their own public kindergarten and primary school (up to 8th grade), and four of 
them also have their own high school and vocational school. However, the local high schools are not very prestigious. Their students systematically achieve low results at the Bacalaureat ${ }^{5}$ and tend to start working as qualified labourers after graduation. For this reason, the number of students who have started to commute to nearby cities to attend high school is quite high, even from those four villages where a local option of secondary schooling is available. The high school students who commute are usually amongst the more dedicated scholars, so after graduation they tend to enrol in a university and move to Zalău, Oradea or Cluj-Napoca. Once there, in order to supplement their income, they start taking part-time or seasonal jobs, creating their own professional networks in the city. Very few return to live and work in the village after finishing their studies, as the jobs they could find in the villages would not suit their level of expertise. Even when some may want to return and start a business themselves, they find that they cannot recreate for themselves the opportunities that they have found in the city. A telling example is that of one respondent's son. He moved to Cluj-Napoca for studies and after he obtained his diploma, he tried to start a tailoring business in the village, but failed because he couldn't find employees:

I gave him the space, I gave him everything, he brought the latest machinery to open a tailoring shop. He barely found two people, and even those rather wanted to stay home. And after one and a half years, one of them moved to England. The other one got married and is on maternity leave, so she benefits now from having been employed. [...] So the boy moved to Cluj [...]. He does well for himself. (interview, Male, aged 57, Treznea, July 2017)

Another strategy employed by the locals, as a response to the low incomes available through employment in the peripheries, is international migration, for different periods of time. As the interviews revealed, some family members of the respondents had emigrated permanently, together with their spouses and children, and are only returning for summer holidays to visit their parents. Although absent, they are still investing in the village. Not only are they sending money back to their parents, but they are also renovating their childhood homes or 
building new houses, indicating that they would still like to return at some point in the future:

The children are abroad, they are working there, have kids on their own. They want to open a business and stand on their own two feet. They want to come here and open something in agriculture, but they keep saying that they'll stay one more year, then one more year. (interview, Male, aged 56, Bănișor, July 2017)

For those not willing to emigrate permanently, temporary or seasonal migration abroad represents the strategy for earning higher salaries. Usually they work in various European countries in agriculture, construction or caregiving. The specifics of their life stories differed considerably. Some were employed most of the year in the village or in a nearby city, but took unpaid leave to work for a couple of months abroad. Others combine episodes of seasonal work abroad with seasonal work locally and with social benefits. However, what came across in all of their stories was the desire to improve the quality of life for their family and the difficulty of having to leave their family behind for months at a time. In fact, the vast majority of the respondents do not want to go abroad for work, but the low salaries in the village or the region push them towards migration. For example, one respondent, who had been working seasonally in agriculture abroad and locally ever since his late teens, said that now he was looking for a job nearby, because he was about to become a father. But he was disappointed in the salaries he was being offered, considering them insufficient to cover basic expenses, especially since his wife has no income of her own:

It doesn't matter where I work, here, in Cluj, in Timişoara, in Spain, as long as we can get by as a family. But to be honest, if I could find a job here that is convenient with a salary of 2000-2200 RON, ${ }^{6}$ I wouldn't travel abroad anymore. I would stay here with my family. But for less money, I wouldn't stay, because we have to buy food, diapers, everything is expensive. (interview, Male, aged 24, Agrij, July 2017)

So while internal out-migrants tend to leave in order to access higher skilled employment in larger cities, in the case of international migrants 
it is not the low quality of the employment available locally that pushes them towards mobility, but rather the low income it results in, and the harsh working conditions it entails. One respondent, who has been working in Italy for 1-2 months each year since 2002 as a caregiver or as an assistant cook, was particularly vocal about how they wouldn't have been able to afford small renovation work on their house in the village or to help their oldest daughter through college in Oradea on just the salaries offered in Sălaj County:

In Zalău at Universal [a factory specialised in clothing manufacture] they are hiring every day. But they can look for employees all they want, if they won't offer salaries. They pay the minimum wage, around 1200 RON I think it is. Then you pay $250 \mathrm{RON}$ for the commute and are left with under 1000 RON. You can't get by with that! [...] That's not even enough to manage on, let alone set something aside. [...] When we moved here, the house was in bad shape and all [the renovations] cost money. If I hadn't gone abroad, we wouldn't have managed anything. Unfortunately, that's where we have to go to be able to do something. [...] Here you work for 4-5 months, there you work for one month. ${ }^{7}$ And it's much more difficult here. (interview, Female, aged 49, Sâg, July 2017)

While the reasons to emigrate and the destinations of out-migration differ, the interviews revealed that there is one common trait that connects all types of migrants: they remain attached to their place of birth. In this sense, it isn't only the long-term international out-migrants who invest in local housing. Seasonal migrants too, invest large parts of their additional earnings in building or refurbishing their houses. And even internal out-migrants often choose to return from the cities to their home villages when they get close to retirement age, craving the quiet countryside life. One respondent, who lived most of her adult life in Zalău and just moved back two years ago, explained:

I always wanted a house in the countryside, because this is where I grew up. I like it here, I like gardening. My daughter visited us earlier today and I was so happy to give her vegetables from my garden. Now nothing could make me move away. (interview, Female, aged 48, Treznea, July 2017) 
The respondents don't mention it explicitly, but it is safe to assume that this favourable perception of the rural lifestyle results largely from improved living conditions in the village. These respondents have managed to substantially improve their housing conditions, by renovating houses, equipping them with bathrooms and appliances, purchasing new agricultural technologies, and modernising their households with the higher income earned elsewhere. And the villages have also been modernised with asphalted roads, running water, television, internet or other services. In fact, improving public services and the available physical infrastructure is one of the main strategies employed by local authorities to encourage commuting over out-migration, or even to attract new inhabitants, as the following subsection will explore in more detail.

\subsection{Development Strategies of Local Municipalities Against Peripheralisation}

Being responsible for devising local development strategies, public officials in peripheral villages are very aware of the challenges brought on by demographic changes. The selective out-migration of young adults, in response to existing peripheralisation, has consequences for the ways in which local administrations can operate. One of the direct consequences of having fewer young adults living in peripheries is that the number of children is also declining. In the villages analysed, kindergartens and schools are struggling with a decrease in the number of pupils and have had to reduce the number of units they operate and sometimes merge classrooms of students together, thus reducing the already poor educational infrastructure even more. When one unit closes, students from that area are usually transported by bus to a different school, which hikes education costs for the local administration:

The number of pupils is decreasing yearly, decreasing strongly... from 2008 until now it decreased around 40\%. There are fewer children, the birth rate is declining. [...] From 2008 until now four school units have closed because there were no pupils. (interview, School secretary, Village 7, July 2017) 
Education costs already put a strain on the local budget because some of the teachers are commuting from the cities nearby, and the villages cover their travel-related expenses:

Some of the employees at the school come from elsewhere. Monthly we pay for the teachers' commute 4000-4500 RON. ${ }^{8}$ They come from Zalău, from Șimleu [Silvaniei], from neighbouring settlements and have their main work quota here. There are also some locals employed at the schools. (interview, Secretary, Village 9, July 2017)

This stems from a more general difficulty in keeping more educated locals as permanent residents, because not only teachers, but also other employees from the public sector are often not locals. More generally, this issue showcases how peripheries depend on cores in order to maintain such essential facilities as schools, day care centres or doctors' offices, since they cannot provide the necessary specialised workforce themselves.

Another problem intensified by selective out-migration-and the implicit population shrinkage that it brings-is low public income. And not only do the peripheral villages collect small incomes from taxes, but they also lack the capacity to attract major economic investors, as large enterprises wouldn't be able to find the necessary work force locally:

Enterprises... it's difficult because with the ageing population there is no way an investor could find sufficient labour force. (interview, Mayor, Village 1, July 2017)

As a result, the villages analysed sourced most of their money from national or European funds. Such a dependence on external funds for maintaining or improving local infrastructure dictates local actions to a high degree, as the villages analysed seek to fulfil the necessary criteria that would make them eligible for whichever funding opportunity is being promoted at that time at the regional, national or European level. When asked about projects implemented in the recent past, public officials mentioned mainly infrastructure investments, including the paving 
of roads, refurbishing of community centres, building of day care centres and touristic information points, as these were the projects promoted through recent funding programmes. This is illustrative of the limited capacity of peripheries to react to actual local needs and to secure a better quality of life for their population. They even acknowledge that sometimes the projects they applied for weren't necessarily a priority, but that they just tried to access as many funds as possible and to make the best of a bad situation:

We had a project that was already approved for a sewage system, the money was already approved, but during the Boc government ${ }^{10}$ they withdrew the funding. [...] So we did what we could then, you know, the money is granted according to programmes. If there is a project for... people don't understand, "why did you refurbish this community centre, we don't need it». Well, it's not about need, that's how they issued funds, on refurbishing community centres. But some don't understand, "why didn't you use the money to implement...». You can't! When it's for paving, it's for paving, you can't move the money where you want. These are European funds, you can't spin it the way you want. So that's why we refurbished as much as we could, even schools, we transformed some of them in community centres. (interview, Deputy Mayor, Village 7, July 2017)

This quote showcases very well how the issue for peripheries is not always a lack of resources. Instead the problem lies in the way in which these resources are allocated, in a way that doesn't engage with local needs and potentials. Sometimes, public officials acknowledge that a certain project would not bring any benefits to their community and decide not to invest time and effort in it. For example, Village 2 refused to apply for European funds for a tourist information centre, even though they were easily accessible at that time, knowing that they don't receive many tourists. In these cases the interviewees were especially vocal about their frustration with the way funds were being allocated, and blamed the national administration for not giving them more support in developing local potential. In the case of Village 2, the mayor considered that their biggest potential was agriculture: 
They made a big mistake in both the previous and the current National Rural Development Programme, because they should have allocated a large part of the money to enable people to open farms. At least two farms with large crop surfaces, or at least two-three farms with animal husbandry should have been created in each village, with several employees. [...] Each farm would have employed 2-3-4 people to operate the necessary machinery. And the employees would have received a salary, paid taxes, and the entire standard of living could have been higher. [...] The Romanian state should have developed, should have made European funds easier to access [...]. The people here have tried, but they cannot meet the conditions for co-financing. It makes no sense how much money they spent on tourist centres here and we have no tourists. (interview, Mayor, Village 2, July 2017)

When asked about how they envisioned the future of their village, public officials said that they would like to see local potential being developed through encouraging larger scale and profit-oriented agriculture, or that they would like to attract investors and more inhabitants. The way to achieve this, they further elaborated, was through accessing more funds. More specifically, their development strategy for stimulating agricultural growth consisted in trying to help local inhabitants to access individual funds offered by the European Union, even if the results of this strategy have been mixed in the past, as locals with such ambitions have to meet strict requirements:

They [trainers on how to access European funds through APIA ${ }^{11}$ ] came and presented here for the people. But the people don't really dare. They face difficulties along the way... Others said too that the requirements are too high, for them to prepare you a project costs I don't know how much... I know people who prepared projects, but didn't follow through. They let it be. And they paid some money and were left without money. Or who wanted to have a pig farm and the poor guy bought the land and now he can't sell it because land was very expensive at that time... and he can't have the farm because he said there were some requirements to get the funds. (interview, Deputy Mayor, Village 7, July 2017)

Such a development strategy for attracting investors and more inhabitants also showcases a high dependency on external funding. As 
a result of selective out-migration and the implicit demographic shrinkage and brain drain, peripheral villages do not have sufficient (and sufficiently skilled) local work force to attract larger enterprises. Therefore, public officials plan to use available funds to invest in the admittedly lacking physical infrastructure and hope that this alone will strongly affect demographic and economic growth. Indeed, over the past years, all villages had seen major investments in basic infrastructure that was meant to improve local living conditions: paving main and secondary roads, trying to bring running water, sanitation system, internet lines, public lighting to as many corners of their village as possible. Some villages were more successful than others. In fact, the case study area suffers from a slow implementation of modern infrastructure, as is typical for peripheries (Bernt and Liebmann 2013), and only two of the villages are connected to gas pipelines, while three of them do not have access to running water. In the interviews, public officials stated their aim to provide all the necessities one could find in a city and hope that, with a better infrastructure, commuting could become more attractive to young adults who would otherwise choose out-migration. Also, in the case of villages closer to one of the cities, authorities plan to attract city dwellers and become suburbanised, thinking that a better connection to the urban core could result in local development. They are encouraged here by an increase in the number of migrants returning:

What I foresee for the future, and I encourage them to relocate here: our village is not far away from Zalău [...]. Many came from Zalău to settle down, building houses [...]. And that makes me happy, this resettlement from the city here, even if pensioners are coming. (interview, Deputy Mayor, Village 7, July 2017)

Additionally, they hope that the improved infrastructure could make the villages more attractive to investors as well, who could then be somehow persuaded to locate there and create jobs:

We hope the village will develop, but we will see if any foreigners come with foreign capital... it would be good... We have many young people who have moved away from the village, because there are no jobs. 
Around 100-200 have left the village permanently and I think that if foreign investments would come, they would stay here. (interview, Deputy Mayor, Village 8, July 2017)

This again highlights the dependency of the case study area to external funding, as well as the limited political power that peripheries have in relation to national or European decision makers. But at the same time, it also shows how peripheries strategise local development in relation to their dominant centre. Without explicitly referring to functional urban areas, the public officials appear to argue in favour of such sociospatial arrangements. It seems that they envision a stronger connection to a nearby urban core as a way to encourage commuting and discourage out-migration, with the implicit effects this would have on demographic shrinkage and ageing and on local budgets. Local leaders also expect that this strategy would generate additional economic spillovers, as investors would take better note of them, were there a better linkage between them and an economic centre. The fact that this strategy would also make them more dependent on that core does not seem to bother them.

\section{$4 \quad$ Re-thinking the Tools for Local Development in Peripheries: Conclusions}

The actor-centred approach that was employed in the present chapter focuses on how at times of polarisation, selective out-migration and local development influence each other. The decision of locals to leave peripheries because of existing structural deficits translates into a decrease of local tax income, active population, local capacity for innovation, and overall local capacities to secure a high quality of life for the inhabitants. This in turn motivates future cases of emigration and creates a vicious circle that reproduces peripherality. In the case study area analysed, locals had chosen to commute or to emigrate from peripheral villages in their pursuit for higher education, better skilled employment opportunities or higher income. Each specific strategy they employ in order to improve living conditions for themselves and their 
family (commuting, internal migration, international migration or temporary migration abroad) reveals different personal values and attachments, and highlights how actors are affected in different ways by the various effects of peripheralisation. But the migration trajectories also expose the different scales of core-periphery dependency. The choices of destination show how peripheral villages are affected not only by nearby cities or the county seat Zalău, but also by regional urban centres, such as Oradea and Cluj-Napoca. It also highlights the peripheral position that Romania as a country occupies at the European scale.

Not being able to compete with urban cores or international destinations in terms of educational and occupational opportunities, and available physical, social and cultural infrastructure, the peripheries analysed experience demographic shrinkage and ageing as a result of youth emigration. This affects their local budgets and their ability to maintain existing public facilities, making them increasingly dependent on external public funds, which are allocated through national or European programmes targeting specific investments, as determined by the issuing institution. However, these are not sufficient to bridge the increasing coreperiphery gap. Empirical analysis has revealed that while all villages in the case study area struggle with the effects of peripheralisation, they do so in slightly varying ways and to different intensities. As a consequence, each village has specific deficits that are more urgent to address, and also different local potentials that could be developed through targeted action. Judging by the narratives of public officials, the policy tools they are utilising at the moment do not enable them to address their most pressing issues in a systematic way, but rather push all villages towards similar strategies and solutions. In this context, a settlement can only hope that their specific issues will become the subject of the next line of funding. This is the reason the current chapter argues in favour of devising and effectively communicating policy tools that would strengthen the ability of local administrations to act autonomously, which would grant them more power in actively influencing how funds allocated for stimulating local development can be spent. Empirical findings have shown that more dialogue is needed between actors from peripheries and regional and national policymakers, in which the former should be given a more active role in shaping the policies that affect them. 
Acknowledgements I would like to thank the monograph editors as well as the anonymous reviewers for their helpful comments on earlier drafts of this chapter. I would also like to thank the entire team of researchers and students from the Faculty of Sociology at the Babeș-Bolyai University Cluj-Napoca for the fruitful collaboration in preparing and conducting empirical research in the Sălaj County.

\section{Notes}

1. For a more detailed view on the methodology employed to measure regional inequalities between the settlements of the North-West Region through statistical data, see Moldovan (2017).

2. One of the two villages excluded from this analysis was described by public officials as having experienced a recent socio-economic increase: the population was growing, larger companies were attracting commuters themselves, some agricultural entrepreneurs had made larger investments, and migration abroad was diminishing. The other excluded village did not experience such socio-economic development. Locals there had pronounced pride in the local agricultural tradition and a strong feeling of attachment to the village, which seems to keep villagers from emigrating or commuting in larger numbers.

3. The fieldwork was organised in collaboration with the Faculty of Sociology from the Babeș-Bolyai University in Cluj-Napoca. Data were collected by a team of six researchers (including the author), who spoke with political leaders and administrative workers, and sixteen undergraduate students, who completed their mandatory professional practice through this fieldwork by interviewing locals. All interviews were held in Romanian, relevant quotes have been translated into English.

4. The position of secretary in Romanian local government refers to an official who holds responsibility for the general management of the town hall. A secretary organises and directly manages the activities of the local administration according to written provisions laid out by the mayor.

5. The Bacalaureat is a national exam held in Romania after the 12th grade, after graduating from high school. 
6. At the time of the interviews (2017), 1 EUR was worth about 4.56 RON. So the amount mentioned, of 2000-2200 RON, is equivalent to 450-480 EUR, and represents about twice the minimum net wage, which at the time of the interview was set at $1065 \mathrm{RON}$.

7. Regarding the sums of money, the respondent is comparing how long it would take to earn about 1000 EUR: one month abroad, and 4-5 months in Sălaj. 1000 EUR seems to be the usual amount of money earned by temporary migrants, as this amount was mentioned by other respondents as well.

8. The amount mentioned, of $4000-4500 \mathrm{RON}$, is equivalent to 900 1000 EUR.

9. In fact, Sălaj County has the second smallest estimated operational budget for County Councils and County Residences, for the 2014-2023 Implementation period in the entire country (Cristea et al. 2017, 139).

10. Emil Boc was the prime minister of Romania during 2008-2012.

11. APIA stands for the Agency for Agricultural Payments and Interventions (in Romanian: Agenţia de Plăţi şi Intervenţie pentru Agricultură).

\section{Recommendations for Further Readings}

Bernt, Matthias, and Heike Liebmann, eds. 2013. Peripherisierung, Stigmatisierung, Abhängigkeit? Deutsche Mittelstädte und ihr Umgang mit Peripherisierungsprozessen. Wiesbaden: Springer VS.

Boyle, Paul, Keith Halfacree, and Vaughan Robinson. 1998. Exploring Contemporary Migration. Essex: Addison Wesley Longman.

Fischer-Tahir, Andrea, and Matthias Naumann. 2013. Peripheralization: The Making of Spatial Dependencies and Social Injustice. Wiesbaden: Springer VS.

Lang, Thilo, Sebastian Henn, Wladimir Sgibnev, and Kornelia Ehrlich, eds. 2015. Understanding Geographies of Polarization and Peripheralization: Perspectives from Central and Eastern Europe and Beyond. New Geographies of Europe. Basingstoke: Palgrave Macmillan.

Moldovan, Aura. 2017. Peripherialisation as a Result and Driving Force of Territorial Mobility in Post-Socialist Romania. European Spatial Research and Policy 24 (2): 39-57. https://doi.org/10.1515/ esrp-2017-0008. 


\section{References}

Benedek, József. 2015. "Spatial Differentiation and Core-Periphery Structures in Romania." Eastern Journal of European Studies 6 (1): 49-61.

Benedek, József, and Aura Moldovan. 2015. "Economic Convergence and Polarisation: Towards a Multi-dimensional Approach." Hungarian Geographical Bulletin 64 (3): 187-203.

Bernt, Matthias, and Heike Liebmann. 2013. "Zwischenbilanz: Ergebnisse und Schlussfolgerungen des Forschungsprojektes." In Peripherisierung, Stigmatisierung, Abhängigkeit? Deutsche Mittelstädte und ihr Umgang mit Peripherisierungsprozessen, edited by Matthias Bernt and Heike Liebmann, 218-31. Wiesbaden: Springer VS.

Boyle, Paul, Keith Halfacree, and Vaughan Robinson. 1998b. Exploring Contemporary Migration. Essex: Addison Wesley Longman.

Cristea, Marius, Codruţa Mare, Ciprian Moldovan, Andreea-Mirela China, Thomas Farole, Adina Vințan, Jane Park, Keith Patrick Garrett, and Marcel Ionescu-Heroiu. 2017. Magnet Cities: Migration and Commuting in Romania. Washington, DC: World Bank. http://documents.worldbank. org/curated/en/327451497949480572/pdf/1 16400-WP-P158178-PUBLIC-MagneticCities-Jun18-v4.pdf.

Fielding, Anthony. 1992. "Migration and Culture." In Migration Processes and Patterns. Volume I: Research Progress and Prospects, edited by Tony Champion and Anthony Fielding, 201-12. London: Belhaven Press.

Fischer-Tahir, Andrea, and Matthias Naumann. 2013. "Introduction: Peripheralization as the Social Production of Spatial Dependencies and Injustice." In Peripheralization: The Making of Spatial Dependencies and Social Injustice, edited by Andrea Fischer-Tahir and Matthias Naumann, 9-26. Wiesbaden: Springer VS.

Gottdiener, Mark, and Leslie Budd. 2005. Key Concepts in Urban Studies. London: Sage.

Gutting, Daniel. 1996. "Narrative Identity and Residential History." Area 28: 482-90.

Ionescu-Heroiu, Marcel, Sebastian Ioan Burduja, Dumitru Sandu, Stefan Cojocaru, Brian Blankespoor, Elena Iorga, Enrico Moretti, Ciprian Moldovan, Titus Man, Raularian Rus, and Roy van der Weide. 2013. Competitive Cities: Reshaping the Economic Geography of Romania. Romania Regional Development Program. Full Report. Washington, DC: World Bank. http://documents.worldbank.org/curated/en/664361468093270286/ pdf/843240v10Full00s0Box382123B00OUO070.pdf. 
Keim, Karl-Dieter. 2006. "Peripherisierung ländlicher Räume - Essay." Aus Politik und Zeitgeschichte 37: 3-7. http://www.bpb.de/apuz/29544/ peripherisierung-laendlicher-raeume-essay? $\mathrm{p}=$ all.

Kreckel, Reinhard. 2004. Politische Soziologie der Sozialen Ungleichheit, 2nd ed. Frankfurt: Campus.

Kühn, Manfred. 2015. "Peripheralization: Theoretical Concepts Explaining Socio-Spatial Inequalities." European Planning Studies 23 (2): 367-78. https://doi.org/10.1080/09654313.2013.862518.

Kühn, Manfred, and Sabine Weck. 2013. "Peripherisierung - ein Erklärungsansatz zur Entstehung von Peripherien.” In Peripherisierung, Stigmatisierung, Abhängigkeit? Deutsche Mittelstädte und ihr Umgang mit Peripherisierungsprozessen, edited by Matthias Bernt and Heike Liebmann, 24-46. Wiesbaden: Springer VS.

Kurkó, Ibolya. 2010. Disparităţi geodemografice şi economice din România în perioada de tranziţie. Cluj-Napoca: Presa Universitară Clujeană.

Lang, Thilo. 2011. "Regional Development Issues in Central and Eastern Europe: Shifting Research Agendas from a Focus on Peripheries to Peripheralisation?" In Geography in Visegrad and Neighbour Countries, edited by Ágnes Erőss and Dávid Karácsonyi, 57-64. Budapest: E-Government Alapítvány.

Leibert, Tim. 2013. "The Peripheralization of Rural Areas in Post-Socialist Central Europe. A Case of Fragmenting Development? Lessons for Rural Hungary." In Peripheralization: The Making of Spatial Dependencies and Social Injustice, edited by Andrea Fischer-Tahir and Matthias Naumann, 101-20. Wiesbaden: Springer VS.

Leibert, Tim. 2015. "Abwanderung Jugendlicher aus postsozialistischen ländlichen Räumen.” Geographische Rundschau 67 (9): 34-41.

Massey, Douglas. 1990. "Social Structure, Household Strategies, and the Cumulative Causation of Migration.” Population Index 56 (1): 3-26.

Meyer, Frank, und Judith Miggelbrink. 2015. "Subjektivität und Kausalität in der Migration(sforschung) - Annäherungen an Rationalisierungen von Migrationsentscheidungen in schrumpfenden Regionen.” Raumforschung und Raumordnung 73 (1): 17-30.

Moldovan, Aura. 2017. "Peripherialisation as a Result and Driving Force of Territorial Mobility in Post-Socialist Romania.” European Spatial Research and Policy 24 (2): 39-57. https://doi.org/10.1515/esrp-2017-0008.

Nagy, Erika, Judit Timár, Gábor Nagy, and Gábor Velkey. 2015. "The Everyday Practices of the Reproduction of Peripherality and Marginality in Hungary." 
In Understanding Geographies of Polarization and Peripheralization. Perspectives from Central and Eastern Europe and Beyond, edited by Thilo Lang, Sebastian Henn, Wladimir Sgibnev, and Kornelia Ehrlich, 135-55. New Geographies of Europe. Basingstoke: Palgrave Macmillan. PoSCoPP Research Group. 2015. "Understanding New Geographies of Central and Eastern Europe." In Understanding Geographies of Polarization and Peripheralization: Perspectives from Central and Eastern Europe and Beyond, edited by Thilo Lang, Sebastian Henn, Wladimir Sgibnev, and Kornelia Ehrlich, 1-21. New Geographies of Europe. Basingstoke: Palgrave Macmillan.

Pütz, Robert. 1999. "Ostmitteleuropa auf dem Weg in die EU.” Praxis Geographie 29 (9): 4-9.

Spoor, Max. 2013. "Multidimensional Social Exclusion and the 'Rural-Urban

Divide' in Eastern Europe and Central Asia.” Sociologia Ruralis 53 (2): 13957. https://doi.org/10.1111/soru.12008.

Surd, Vasile, Ianos Kassai, and Laura Giurgiu. 2011. "Romania Disparities in Regional Development." Procedia Social and Behavioral Sciences 19: 21-30. https://doi.org/10.1016/j.sbspro.2011.05.102.

Török, Ibolya. 2014. "From Growth to Shrinkage: The Effects of Economic Change on the Migration Processes in Rural Romania." Landbauforschung 64 (3/4): 195-206. https://doi.org/10.3220/LBF_2014_195-206.

Warf, Barney. 2008. "From Surfaces to Networks." In The Spatial Turn: Interdisciplinary Perspectives, edited by Barney Warf and Santa Arias, 59-76. London: Routledge. 
Open Access This chapter is licensed under the terms of the Creative Commons Attribution 4.0 International License (http://creativecommons. org/licenses/by/4.0/), which permits use, sharing, adaptation, distribution and reproduction in any medium or format, as long as you give appropriate credit to the original author(s) and the source, provide a link to the Creative Commons license and indicate if changes were made.

The images or other third party material in this chapter are included in the chapter's Creative Commons license, unless indicated otherwise in a credit line to the material. If material is not included in the chapter's Creative Commons license and your intended use is not permitted by statutory regulation or exceeds the permitted use, you will need to obtain permission directly from the copyright holder. 


\title{
11
}

\section{Towards a Progressive Local Development Approach: Insights from Local Community Initiatives in Hungary and Romania}

\author{
Sorin Cebotari and Melinda Mihály
}

\section{Introduction}

High unemployment rates, the falling availability of public transportation, the shrinking quality of locally available education, local shops going out of business, the closing down of post offices, schools or kindergartens, and selective out-migration are all manifestations of peripheralisation, which particularly affect rural communities in Central and Eastern Europe (CEE). Rural settlements across CEE often struggle to find a development path that allows them to reverse these dynamics. In some cases, village-based initiatives aiming to counteract peripheralisation emerge from these settlements. This chapter looks

\footnotetext{
This chapter represents a joint contribution of both authors. Melinda presented the Hungarian case while Sorin introduced the Romanian one. The introduction and policy recommendations are a joint effort of both authors.
}

S. Cebotari $(\bowtie)$

Research Center for Sustainable Development, Faculty of Geography Babeș-Bolyai University, Cluj-Napoca, Romania 
into two examples of such initiatives from Hungary and Romania. In each case, the projects were initiated and managed by the local authorities-local mayors.

While developed by local authorities, we still consider these projects as community-owned. We acknowledge that they might not comply entirely with the definition of a community-owned project in the end. However, given the CEE context, these initiatives dominate the landscape of local development projects and are the closest examples to a community-owned project one can find. Both the Hungarian and Romanian case emerged in areas where development policies failed to reverse processes of peripheralisation. Villages undergoing peripheralisation lose those inhabitants who could become drivers of communitybased local development. On the other hand, local civil society is decreasingly involved in publicly funded, local development projects. For this reason, it is understandable why mayor-led projects dominate the landscape of local development in CEE. The question might rise though whether mayor-led development projects are capable of enabling locals to participate and actively shape local development projects. Our research looks closely into that since local participation is an integral part of locally driven development.

This research presents the development of community-owned projects from CEE and should be considered as complementary to the abundance of studies on community-owned initiatives from Western Europe (Hanley and Nevin 1999; ADAS Consulting 2003; Walker and Devine-Wright 2008; Hargreaves et al. 2013; Seyfang et al. 2013; Becker et al. 2017). It is therefore imperative to consider the developments from CEE in their own context, applying only to a certain degree the terminology and conceptualisations developed for similar studies in Western Europe.

\section{Mihály}

Centre for Economic and Regional Studies, Hungarian Academy of Sciences (CERS-HAS), Leipzig, Germany

M. Mihály

Centre for Economic and Regional Studies, University of Leipzig, Leipzig, Germany 
Studying a Hungarian social and solidarity economy (SSE) initiative and a Romanian community-owned renewable energy project (REP), we are primarily interested in the following questions:

- What is the capacity of local initiatives to change the peripheralisation dynamics by enriching the capabilities of local actors to innovate and acquire broader economic and political power?

- To what extent do mayor-led, local development projects foster local participation?

- What can be improved or changed within the existing policy approach towards the development of community involvement in the process of local development, thus increasing the efficiency of development policy?

While formulated separately, all three questions are interlinked and to answer any of them we would have to discuss the other two as well; thus, throughout our research we answer all of them combined. Further on, the chapter introduces our theoretical perspective and main normative argument followed by a short methodological outlook. The fourth and the fifth sections analyse the two cases of community initiatives from Hungary and Romania, respectively. The conclusion summarises the main findings and answers the main points raised in the introduction. In the last section we offer policy recommendations based on our theoretical and empirical materials.

\section{Counteracting Peripheralisation Through Capability-Based Local Development?}

Peripheralised spaces are often simultaneously affected by selective out-migration, shrinking public infrastructure and the decline of local economies. These different manifestations of peripheralisation amplify each other's effects (Kühn 2015). To go against the various manifestations of peripheralisation, the traditional understanding of local development needs to be questioned (Fischer-Tahir and Naumann 2013). 
Economic concerns, such as growth, income and employment have historically dominated the concepts of local development (Armstrong and Taylor 2000; Pike et al. 2007). This traditional local development was commonly the subject of a top-down national spatial policy (Pike et al. 2006, 26), grounded in solid macro and micro economic theories (Crescenzi and Rodríguez-Pose 2011). The priority of economic development left socio-environmental issues lagging (Winter 2016, 131) and contributed to further peripheralisation. Currently, a new approach to local development that brings local agency to the forefront is developing (see Eversole et al. 2014; Evans and Syrett 2007). In the analysis of our case studies we aim to go beyond the economic dimension of local development and shed more light on local actors and better understand the social sustainability of local development projects.

We look at mayor-led local development projects through the lens of a capability approach to understand in what ways local development projects may (or may not) go against the processes of peripheralisation. Within the capability approach it is argued that even if the inhabitants of peripheralised areas get marginalised, they have an agency and are capable of advocating their own interests. Therefore, they cannot be considered passive recipients of development projects (Sen 1999). For this reason, it is important in any local development project to build on the strategies of locals and make them capable of changing their destinies and live with their opportunities (Gébert et al. 2016, 27). As Sen puts it: "Greater freedom enhances the ability of people to help themselves and also to influence the world, and these matters are central to the process of development" (Sen 1999, 18). To advocate one's own interests, one needs basic skills. For this reason, the inevitable element of capability-based local development is to eliminate shortages of certain skills. Thus the idea of empowerment is closely related to deliberative participation (Kesby 2005). For this reason we are particularly interested in the governance of local development initiatives. At the same time we are aware that for marginalised communities it is "often difficult to gain access to processes of political decision-making from which they may be culturally, educationally, and linguistically, as well as physically, remote" (Amin et al. 2002, 17). The exclusion of local citizens from processes of decision-making is striking in CEE. Mészáros, 
a civilian and expert of local (community economy) development projects in Hungary describes the situation as follows:

Discussing trust between each other in an environment where decisionmakers clearly do not trust the competencies of the locals is only theoretical. (Mészáros 2013, 93, translated by the authors).

The lack of involvement of citizens in decision-making during state socialism and later on during the post-socialist period has negatively influenced the development of CEE citizens' civic engagement. Another reason for the low level of civic engagement could be that a high ratio of the population is at risk of poverty and social exclusion $37.3 \%$ in Romania and 28.2\% in Hungary, Eurostat 2016, estimated data for 2015). Those people who have been pushed to the periphery of a society fear for their futures and put most of their energy into developing survival strategies for their everyday challenges. Expecting marginalised people to be societally engaged without supporting them may be unrealistic (Harkai 2006).

Civil society was oppressed during state socialism in CEE and did not become a real partner of the state in the post-socialist period either (Fekete et al. 2017). Compared to Western Europe, civil society is weak and underfinanced in CEE (Fekete et al. 2017; Ciepielewska-Kowalik et al. 2015; Defourny and Nyssens 2014). This already weak civil society is further weakened through getting institutionally excluded from the public funding of local development projects (for Hungary see Kabai et al. 2012; Keller 2011). Mayors are local development actors who are capable of accessing governmental (EU and national) funding in local development policies. Therefore local development projects run by the local municipality are dominant in CEE. For this reason we decided to analyse two different types of local initiatives, both run by local municipalities from two different CEE countries.

Even though in our case study local initiatives are of different types and from different countries, the similarities between the challenges and opportunities encountered in both cases are striking. During our initial inquiry we were surprised by the way in which similar background dynamics were present in both cases, regardless of their type 
or geographical location. While with a limited capacity for generalisability, our research presents a detailed account of the interplay between national policies and locally rooted initiatives. Without using comparative methodology, we present a detailed account of each case, offering a clear understanding of common challenges and similar problems faced by local initiatives. Based on this understanding, we outline a series of public policy proposals that could address the main shortcomings and serve as a guiding agenda for supporting local development initiatives.

\section{Methodological Approach}

We apply storytelling while communicating and conducting our research. Stories are central to human existence and, as Lewis (2011) argued, it may be beneficial to use storytelling in doing and communicating research. Semi-structured interviews provided us a space to listen to the emerging stories of our interview partners and therefore "to give voice to the voiceless" (Lewis 2011, 506), but storytelling is also a better method of communicating our research to a wider audience.

\subsection{Research Methods}

In both cases, we conducted semi-structured interviews with all the involved actors which constituted the basis of our empirical data. This technique allowed us to translate main theoretical concepts into guiding questions while also giving the opportunity to keep an open mind regarding other possible points arising during the interviews. Complementary to that we used participant observation, secondary and primary statistical data in order to acquire a better understanding of the context before and while meeting with the interviewees.

For our interviews, we relied on a snowball sampling technique, using as an entry point the official manager/owner/responsible person from the project. From there on, we tried to map the entire population of involved actors by asking every interviewee to name another involved actor. We repeated the process until no new actors were mentioned. 


\subsection{Case Selection}

Despite the research methods being similar for the two projects, we applied a different means of case selection. The Hungarian case was selected using a two-step case selection method. First we identified the peripheralised areas, relying on existing research on regional polarisation (e.g. Koós 2015; Kovács 2010, 2012; Dusek et al. 2014; Pénzes 2015). After that, "best practice" bottom-up local development initiatives were selected by consulting 12 experts from the field of local development and SSE and by examining awards and "best practice" reports. Finally three cases were selected from those peripheralised villages of Hungary that had the highest deprivation index (Koós 2015). The first of the three selected cases, an organic village farm run by the local mayor, will be introduced in detail further on in this chapter.

The Romanian case was also selected using a two-step case selection method. First we mapped all the villages in which renewable energy projects (REPs) were being undertaken, but in doing so we relied on secondary statistical data. After that we used a phone questionnaire to get in contact with local authority representatives to find projects owned by the local community or projects in which the local community had an important share. Only in 2 of the 68 localities with ongoing projects did the local community own the project. Since we are primarily interested in bottom-up, locally based initiatives we chose to look closer at these two cases. As the technology-community interaction developed similarly in both villages, in this chapter only one REP will be presented. The story of Hustiu ${ }^{1}$ village highlights best the benefits and shortages that are common to both cases.

\section{The Hungarian Case: The Organic Village Farm of Kispatak}

The centralisation of local development in Hungary, which has been ongoing since the second half of the 1990s, had a negative impact on traditional civil society organisations (CSOs) and small- and medium enterprises (SMEs), particularly on their ability to access national and 
EU funding for local development (for a detailed overview see Kabai et al. 2012; Keller 2011). Due to this centralisation process, civil and municipal actors ceased to be interdependent, as the latter gained privileged access to funds for rural development and became unevenly represented in decision-making processes. Therefore, mayors of villages have higher chances of accessing national (such as workfare support) and international funding (such as EU funding), while traditional CSOs are struggling. As a consequence, mayor-led social and solidarity economy initiatives are dominant in remote, rural areas.

To overcome regional inequalities in the 2007-2013 financing period the 33 "least privileged micro-regions" (Leghátrányosabb helyzetü kistéréség, LHH) were privileged in accessing funding for rural development (Government Decree no. 311/2007. [XI. 17.]). However, while the programme was successful in channelling more EU funding into peripheralised areas (Kabai et al. 2012) it was criticised, amongst others, for privileging local mayors too much over other local actors. Czike $(2011,12)$ argues that the first period of the LHH Program became "the playground of the local mayors" and civilians, entrepreneurs or representatives of Roma could not make their voice heard.

\subsection{General Context and Case Description}

To better understand the potential and shortcomings of SSE initiatives in the context of peripheralisation, a mayor-led project, an organic village farm, was purposefully selected from Kispatak, ${ }^{2}$ a small and remote village in Northern Hungary in one of the 33 "least privileged micro-regions" that were privileged in accessing public funding for rural development between 2007 and 2013.

The different manifestations of peripheralisation, including economic and infrastructural shrinking, have been amplifying each other's effect in the village, making it less attractive to middle-class families. Due to the economic crisis in the years after the regime change, the agricultural cooperative-which, as in many other villages of Hungary, was the main employer in Kispatak (see Kovách 2012)—needed to close down in the early 1990s. The likelihood of living in poverty in 
Kispatak is particularly high compared to other settlements of Hungary (Koós 2015, see Map 1). Roma people, who are deeply affected by socio-spatial marginalisation in Hungary (Nagy et al. 2015), are overrepresented in the village. Based on the Community Intervention Plan, $40 \%$ of Kispatak's inhabitants are of Roma origin (Anonymised Source $2011),{ }^{3}$ while the ratio of Roma people at the national level is only $3.2 \%$ (KSH 2013).

In 2007, the mayor of the village set up an organic farm to tackle long-term unemployment and poverty by giving the village a new purpose. The mayor of Kispatak argues that the main challenge his village faces is that it has lost its function, such as producing food for the cities, something that is common for settlements of this size (Interview, Kispatak, 23 March 2016). For this reason, the mission of the initiative is to re-establish this function by producing healthy and environmentally friendly organic food at reasonable prices. Through this activity

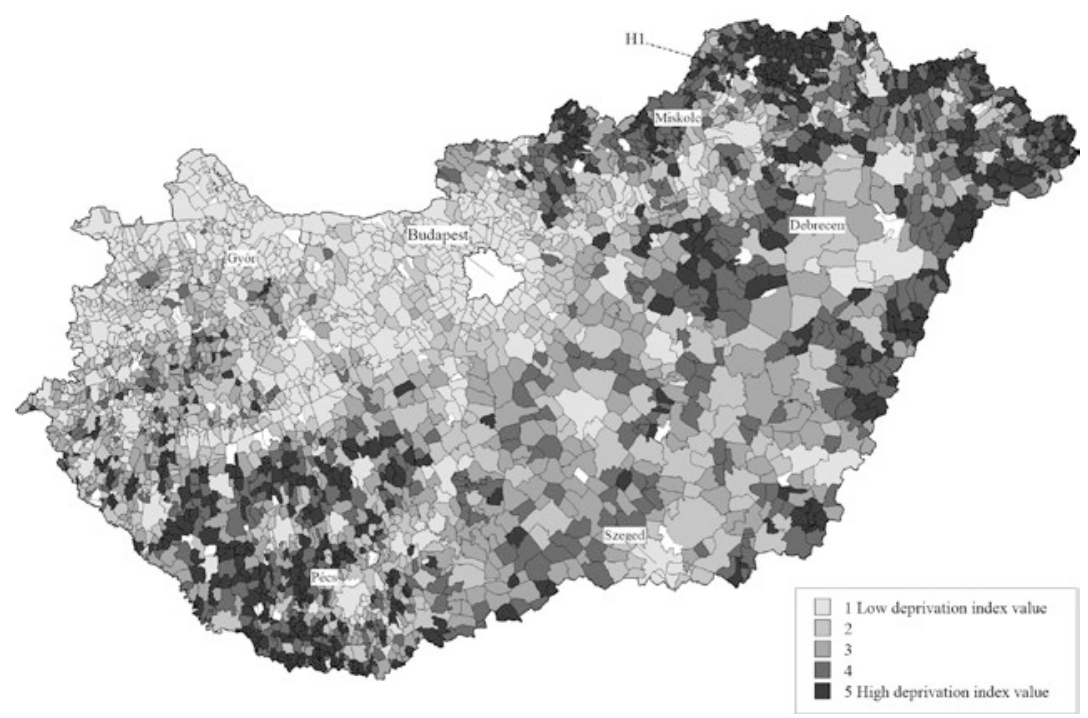

Map 1 Settlement deprivation map of Hungary, 2011 (Source Koós 2015, 64). Kispatak ( $\mathrm{H} 1$, indicated by Mihály) is located in an area where settlements with a high deprivation index are concentrated 
meaningful local employment ${ }^{4}$ would once again become available in the village.

The programme effectively started in 2012 with 25 local volunteers who cultivated 0.6 ha, and grew to 3.5 ha in 2015 and 30 paid employees. In 2012, organic vegetable and fruit production was supplemented with a village shop and handicrafts centre, a food processing manufacture funded by a LEADER grant in 2013, and a herb processing manufacture funded by an ESF grant in 2014.

\subsection{Potential and Shortcomings of the Project}

\subsubsection{Potential Outlined in Best Practice Reports}

[The organic village farm project] became a best practice, not only in the region, but in the whole country. Parallel to this the local identity, the working culture, the self-esteem of the people has positively changed, which is a large step. (Katonáné Kovács et al. 2017, 6-19)

The organic village farm of Kispatak is widely regarded as a "success story" in academic and policymaking spheres. ${ }^{5}$ Articles written about the organic village farm emphasise that the locals do not wait for someone to solve their challenges. Instead, "they" take their own future in their hands. The question might arise whether "they" refers to the whole village or only to some inhabitants? Continuous development or growth was also emphasised in a Best Practice Report referring to the farm as a success story (Anonymised Source 2016). ${ }^{6}$ Specifically, growth in land (more land became available in the project), growth in the number of involved people and growth in the number of activities (the organic farm's shop expanded to include handicrafts, food and herb processing) are highlighted. It may be argued though that the growth of the initiative was not a success in itself, but the result of optimising the use of the resources (EU funding or workfare project), which were made available predominantly for mayors through rural development or employment policies. 


\subsubsection{Dependency on Workfare Project}

Of the three activation programmes (labour market training courses, wage subsidies and workfare programme), public employment (or workfare programme) is the one that explicitly aims to increase the employment of disadvantaged people (Fekete et al. 2017, 27). The programme has grown rapidly in recent years, affecting thousands of people. Workers in public employment are continuously settling into secure income, which is less than the minimum wage in Hungary. A public work employee earns 160 EUR net per month, while the official minimum wage in Hungary was around 230 EUR net in 2016. Only 5\% of programme participants have successfully settled in the primary labour market (Csoba and Nagy 2011). This is by far the worst result among active labour market instruments.

In the case of the organic village farm all employees are employed through public employment (of the total number of workfare employees in the village, 25 work in the organic farm). Only the two experts in sales and gardening are employed through normal labour contracts. By providing low-paid workfare employment for about $32 \%^{7}$ of its active population, the local municipality has become the largest employer in Kispatak. ${ }^{8}$ However the policy aim of public employment is to make local projects independent of public funding; activities financed through the public employment programme mainly mean savings of costs for the local municipalities (Váradi 2016, 30). Even though the organic village farm produces goods for the market and their earned income has nearly tripled in four years (from 3000 EUR in 2012 to 8874 EUR in 2016), 2016 was the first year when the non-profit limited company could officially employ people through conventional labour contracts (the two experts).

From the perspective of the employers, who are mainly local municipalities, ${ }^{9}$ workfare projects provide a cheap local workforce, which is a competitive advantage over organisations that do not have access to workfare projects. Having privileged access to workfare employment, local municipalities can build products and provide services at lower costs than SMEs and traditional civil society organisations, which may 
distort the market. Public work employment can be problematic from the perspective of long-term unemployed people also, as people who are employed in these kinds of SSE projects are paid low wages. The fact that the beneficiaries of the organic village farm must work for less than the minimum wage affects their motivation and self-esteem negatively (Field notes Kispatak, 11 May 2016).

\subsubsection{Providing Meaningful Work for the Workfare Employees}

The idea of the current workfare employment fits very limitedly with the capability-based approach. Since its reform in 2007/2008 public employment has been increasingly embedded in "a turn towards an exclusionary social policy" (Zolnay 2013). People affected by poverty, who are often inhabitants of peripheralised rural areas, get stigmatised in "neoliberal", "radical municipal" and "far right" discourses. Within these discourses people affected by poverty are seen as having had a choice in deciding whether they want to live from transfer payments or conventional employment (Zolnay 2013). Workfare employment was introduced to provide employment instead of social benefits to people affected by poverty. Practical experience in Hungary shows that local governments, the main local coordinators of workfare programmes, are not able to provide real work for less qualified public employees, and often recruit them for "pretend" work. The project of Kispatak deviates from this practice and aims to provide meaningful work for the target group. Through their trading activity their aim is to become less dependent financially on public funding (Interview, Kispatak, 23 March 2016).

\subsubsection{Participation, Power and Decision-Making}

Ethnographic fieldwork in Kispatak has revealed a certain degree of hierarchy between the three branches of the initiative. The organic garden was subordinated to all other branches, such as handicrafts and sales, and fruit and vegetable processing. Those working in the different branches seemed to accept and confirm this hierarchy: 
During a visit to the handicraft house, Marika, an employee of the handicraft and sales branch starts to tell her view about the work in Kispatak. According to her, the workers in the garden are the ones who did not perform 'well enough' to be moved from there. For that reason they had to stay in the garden. Marika does not like to work in the village garden due to the 'crudeness' of the people. They are always swearing, she says. (Field notes, Kispatak, 10 May 2016)

During a visit to Uncle Jenő, who is a Roma and leader of the workers in the organic garden, we met his wife. His wife told us that she was able to "get out" of the organic garden due to her back pain. Now, her responsibility is to plant flowers in the public spaces of the village, which is a much "calmer" job, she said (Field notes, Kispatak, 11 May 2016). In addition to Uncle Jenö's wife, the workers in the organic garden feel that working in the village garden is a punishment for them (Field notes, Kispatak, 11 May 2016).

Workers from all the different branches agreed that working outside of the organic garden is a somewhat privileged position. This might be problematic, as the garden is in the very heart of the organic village farm project, giving jobs for half of the project employees. Tensions inside the organic village farm could be curbed by providing an opportunity for people to rotate within the three different branches. Another way of easing these tensions would be to involve people more in the operation of the village farm, and later on to let them decide themselves in which branch they would like to work.

There are two contrasting views on how certain decisions are made in the organic village farm. The mayor argues that the municipality is responsible for securing financial and non-financial resources, but they let the experts decide on professional questions. However, one of the two experts on the farm shared a story that contrasted with the mayor's description of decision-making processes:

Uncle Karcsi (gardening expert) showed me the farm's lavenders. They were moved a few years ago. He told me that it had been a sore point for him that no one asked his opinion where the lavenders should be replanted when the decision was made. (Field notes, Kispatak, 11 May 2016) 
During our fieldwork in Kispatak we got the impression that the project was rather hierarchic and centred around the mayor, who has invested a lot of energy into the project taking on most of the responsibilities and control over the decisions. The mayor is the one who took the future of the village in his hands in the sense that he is the one who mainly defines the direction of local development (Interview, Kispatak, 23 March 2016).

\subsection{Kispatak, Lessons to Be Learnt}

As a result of re-structuring the agricultural sector, the inhabitants of rural areas became particularly affected by the labour market crisis that characterised the early transition period. As there was a very limited number of alternatives for the unemployed to get a job locally, current local development strategies within CEE need to tackle long-term, in several cases generational, unemployment. Long-term unemployment, public funding and local development are interconnected in Hungary.

By initiating the project in Kispatak, the mayor gained access to national and EU funding and made it available for the community. National funding was channelled through the workfare project and covered employment costs, which are the main fixed costs of the initiative. EU funds contributed to the acquisition of most of the assets. Since 2010, Kispatak has been awarded around 600,000 EUR of EU funding for implementation of the project. Considering how neglected small and remote settlements were in the rural development policy during socialism and after the regime change, the amount of EU funding that Kispatak had access to is justifiable. Nevertheless, it would be of particular importance to open up both project-based funding and funding on a statutory basis for local development actors other than mayors. CSOs or SMEs engaging in local development initiatives should also have equal access to national and international public funding.

In terms of social policy, studies on peripheralisation show that citizens living in peripheralised rural areas cannot be considered exclusively accountable for their poverty. It would be important therefore to transform policy more in line with the capability-based approach. 
Considering that the workfare programme is expensive and ineffective in reaching its aim, namely the integration of long-term unemployed people into the labour market, the state could substitute the workfare programme with a framework to increase the capabilities of the inhabitants of peripheralised areas. Apart from local municipalities, CSOs and SMEs should also become partners of the state in the (re-)integration of the inhabitants of peripheralised areas. All actors involved in local development processes (local municipalities, CSOs and SMEs) must have equal access to funding on a statutory basis. This funding could be given based on the number of long-term unemployed people that the organisation could employ.

\section{The Romanian Case: A Renewable Energy Project}

By researching the relationship between rural communities and REPs ${ }^{10}$ in North-West Romania we expected to find some positive impact on rural development resulting from this relationship. After statistical analysis of large- $\mathrm{N}$ secondary data and the analysis of primary data from the questionnaire completed by local authorities, we found that REPs had no impact on the socio-economic indicators of the host communities. This finding goes against a significant stream of literature that argues that once implemented, REPs could serve as a source of local growth and development (OECD 2012; ADAS Consulting 2003; Del Rio and Burguillo 2008; Cuellar 2012). It was surprising to find that not only was there no sign of a positive impact, but the connection between the project and the local community was absent as well. Local authorities acknowledged the lack of any effect of the project on their well-being, highlighting also that they had little real interaction with the project so they do not expect any benefits for their community to start with. Of the 52 communities that had set up solar power projects, 2 local authorities had a completely different assessment of their relationship with the project and the project's benefits for them. In both cases, local 
authorities owned the solar power project and set each of them up by gaining access to EU structural funds.

Defining community renewable energy projects (COREPs) as projects "where communities (of place or interest) exhibit a high degree of ownership and control, [...] benefiting collectively from the outcomes" (Seyfang et al. 2013), Becker, Kunze, and Vancea highlight a list of possible benefits brought by COREPs. Of them the most important are "addressing climate change, the overall reduction of energy consumption, the protection of biodiversity, sustainable agriculture, a transition town agenda, or social justice and the empowerment of disadvantaged social groups [...] increas[ing] the acceptance of community energy schemes among the population" (Becker et al. 2017, 28). Building on that argument, we claim that the ownership of the project can have a serious and lasting impact on a community's well-being by also influencing local innovation capacity and political engagement. To observe whether it was true for the two community-owned projects we went to these communities and mapped their interaction with the project. The resulting story of the socio-technological interaction uncovers interesting opportunities for alternative, sustainable development at the local level as well as major shortcomings preventing this development.

\subsection{General Context: "Overall... It Looks Great"}

In 2009, the Romanian government increased its support for renewable energy projects in order to achieve Europe 2020 goals (Directive 2009/28/CE). The increased level of financial support led to an impressive development of the renewable energy sector (Cebotari et al. 2017). The share of renewables ${ }^{11}$ in the power generation mix increased from less than $1 \%$ in 2010 to $11 \%$ in 2014 .

The North-West region has the highest number of solar, hydro and biomass power projects, which means that within a general growing trend, the North-West leads in three of four major types of renewable energy generation technologies. Contrasted with quickly rising polarisation within the region (Benedek and Moldovan 2015), it represented an interesting case for our research. 
Development of the renewable energy sector is mostly due to a very generous green certificate support scheme (Legea 220 din 27/10/2008). It was private energy and non-energy actors who invested in renewable energy technologies in order to benefit from high energy prices as well as from green certificates. ${ }^{12}$

Wanting to capitalise more on the fast development of the renewable energy sector, in 2010 the government designed a different initiative aimed at boosting renewable energy generation by encouraging community ownership of REPs. By offering financial assistance to rural authorities, policy-makers expected this initiative to encourage local authorities to develop their own project, through which they could reduce unemployment in rural areas, increase revenues to the local budget and include isolated communities in the national economic circuit (Organismul Intermediar Pentru Energie 2010a). This initiative is an alternative to green certificate allocation; however, the two are mutually exclusive, which means that if you accessed financial assistance for project deployment you cannot apply for green certificates, at least in the first five years of the project's activity.

Of the 172 REPs registered in rural settlements in the North-West region, only two solar power projects owned by local authorities in rural settlements resulted from this initiative (Cebotari and Benedek 2017; Transelectrica 2015). This result raises important questions regarding the policy's efficiency. Given the good intentions and great opportunities for local communities, why do we have so few community owned projects? And, more importantly, how are those projects performing?

\subsection{Looking into Details: "Locally Owned Solar Power Project-Potential and Shortcomings"}

\subsubsection{Locally Owned Projects Without Local Involvement}

To understand the co-evolution of REPs and the dynamics of local communities, semi-structured interviews were conducted with all local actors involved. Contrary to initial expectations, the mayor and the 
vice-mayor of Hustiu were the only persons involved in the process of application, deployment and management of the project from the local community's side. When applying for financial support, they contacted an external company from Oradea ${ }^{13}$ that put together the business case for the project on behalf of the community. Once confirmed, another private company from Cluj-Napoca ${ }^{14}$ set up the project. A third private company from Oradea is now in charge of management and daily activity of the project. So except the mayor and his team, there are no other local actors involved throughout any stages of the project. This initial finding was puzzling since community-owned projects should have a wider engagement of local actors.

\subsubsection{Expected Benefits and Real Payoffs}

When discussing the main reason for setting up a solar power project, the mayor mentioned that there were two complementary rationales: the necessity to decrease the community's public energy spending and the opportunity to access EU funding. He did not expect the project to create local employment or more community engagement from local actors (Interview 1, Hustiu, 26 February 2016). According to Organismul Intermediar Pentru Energie, local authorities (i.e. the local mayor) are the only elective actors who can submit the application for a community-owned project ${ }^{15}$ and who can become the owner of the project (Organismul Intermediar Pentru Energie 2010b). The fact that the mayor did not expect the project to have any impact on local involvement has shaped the way in which the project was implemented. In addition, there is a clear disconnect between the goals of the support scheme, to create employment and local engagement, and the view of local authorities regarding the impact of the project.

However, the project helped Hustiu cut its annual public electricity related spending by $70 \%$. These financial savings allowed larger flexibility for the local budget and the mayor was able to invest in other local projects. Regardless of these benefits, the mayor said that, if given the chance, he would not proceed with the application again for two reasons. First, at the local level, the community did not appreciate the 
effort to deploy the project and, second, at the national level the mayor had to fight a complex and unclear legislation in order to be able to implement the project.

As the mayor pointed out, no one really appreciated the work involved in setting up the project since "they saw no direct benefit to their own pockets. Explaining to them that we could have better side-walks or a renovated kindergarten does not work" (Interview 1, Hustiu, 26 February 2016). The vice-mayor, however, confirmed that there was no strategy to communicate the results of the project to the wider community and that there were no other community actors involved in setting up the project because there was no need for that (Interview 2, Hustiu, 27 February 2016). Also, the private manager of the project said that he believed that there was no real connection between the authorities and the community when it came to discussing the activities and benefits of the project (Interview 3, Hustiu, 27 February 2016).

At the national level, local authorities had to face a difficult challenge. While the project was set up in accordance with the guidelines set by the Ministry of Energy, those guidelines proved to be incompatible with the rules set by Transelectrica, Romania's national transmission and balancing operator. The guidelines also contradict some of the regulations set by Romania's national regulatory authority for energy (ANRE). As pointed out by the mayor, to avoid breaking the funding agreement and be able to benefit from the energy produced in the project, he had to travel several times to Bucharest and get special exemptions in order to operate legally. This negotiation process took more than nine months and proved to be quite difficult for the local authorities since it required in-depth knowledge of energy legislation (Interview 1, Hustiu, 26 February 2016).

In this context, the community-owned project seems to be placed in between Bucharest and the local community. While the rural settlement stands to benefit from the project, the central authorities establish the rules and norms and those can be negotiated or changed only in Bucharest. This leaves the members of the community outside of the project management scheme. There is no communication regarding the benefits of the project, no negotiation over the redistribution of those 
benefits and no real debate over the project's future development. As it stands, local authorities have to involve national regulators to negotiate local development while leaving local actors outside because they lack the time and resources.

\subsection{Visible, Invisible and Lost Benefits}

The mayor concluded that, apart from financial savings, which are an important gain for the local community, there are no other important benefits. If given another chance, the mayor would not take on this opportunity again because the amount of work invested in the deployment of the project was far more costly than the benefits.

Surprisingly, however, the mayor and his team were already working on another application for a micro-thermal plant project that would supply heating to all public buildings while also serving as a possible resource for a local thermal spa. He plans to make this investment partially from the local budget but most money will come from EU structural funds allocated through the national government. He saw no contradiction with his earlier comments because the new project "will not be connected to the national grid, it will be operated locally, we don't have to get involved with anyone from Bucharest, once approved it is with us, here, locally" (Interview 1, Hustiu, 26 February 2016).

The concept the mayor was referring to is "distributed generation", a strategy that allows the producer to consume the energy locally without feeding it to the national grid. In this way, the mayor of Hustiu can avoid all the taxes and levies and manage the village's own energy consumption and production, while also decreasing heating costs. This innovative practice is rooted in his experience with the solar power project, an experience that produced more than simple financial savings. It offered local actors the possibility to learn the most efficient way of producing and consuming energy, forced them to negotiate benefits for their community at the central level and helped them to push their local agenda to national policymakers. In this respect, the solar power project has produced important indirect benefits for local authorities that have 
learned to innovate in the field of energy, got engaged in the energy governance scheme and adapted their future development strategies accordingly.

However, there are lost opportunities as well. Due to both national regulations and local disinterest, local actors are still excluded from the development of REPs. This is a lost opportunity to increase community involvement, create employment opportunities, and develop a local network of entrepreneurs in the field of renewable energy technologies. This is the reason it is still too early to discuss sustainable development enabled through renewable energy technologies. A proactive local authority can play an important role in promoting this type of development, but without wider community involvement projects run the risk of being easily dumped once local authorities change.

\section{Conclusions}

While acknowledging the limitations of case studies and storytelling research, we still believe the two stories presented within this chapter offer an interesting and insightful perspective on local development. So in the end, what did these two cases reveal regarding the potential of local initiatives to reduce peripheralisation and what are the major shortcomings?

As we saw from both stories, mayor-led projects are not opened up to community participation. Since local authorities are favoured when it comes to accessing financing for such projects, it is hardly surprising that they also assume a leading role in project implementation. What is unsettling however is the lack of wider engagement of local actors, even at the individual level. While local authorities believe that they act on behalf of the community, they do not make any visible effort to engage wider participation and ensure growing potential throughout the community. As argued in the theoretical section of this chapter, we view wide community engagement crucial for locally led development in order to counteract peripheralisation dynamics. 
Despite this important drawback, we acknowledge that in the specific economic and social context of CEE, these two cases represent the best of what's possible in terms of community projects. Accepting this reality, we argue that local decision-makers used the existing policy framework to lay the foundations of a locally-rooted initiative that brought financial and non-financial benefits to the local community. Moreover, these projects have positive externalities that could impact peripheralisation processes in the long run, the most important of which being the increasing capacity of local authorities to negotiate with national and regional authorities to shape projects to their own needs and the innovative thinking which allowed them to integrate the project within the local landscape without breaking the funding agreement.

To summarise, the projects as they are now have had little to no impact on deeply rooted peripheralisation dynamics. Nevertheless certain changes that occurred through the two projects might offer some foundation on which innovation and wider engagement can develop. Current, mayor-led projects are closed to the public and not adapted for wide community engagement; therefore they have limited capacity for empowerment. If this challenge can be overcome, the projects may have a better potential to reverse peripheralisation dynamics in those communities.

These two cases are interesting examples of the mismatch between existing conceptualisation of community-owned projects in Western Europe and the practical situation in CEE countries. Both cases offer a good example of an intermediary stage of development, one in which the projects are bound to local communities and are not led by the central government or private actors, but are still halfway towards a wider, participative community engagement. Our contribution takes a bottom-up perspective and considers that in times of rising polarisation local development should be primarily connected to local communities. In this respect, our main contribution to the field lies in the problematisation of two main aspects: first, what is a community initiative in the context of CEE as compared to the examples from Western Europe and, second, can we still consider these types of projects promising for locally rooted development? 


\section{$7 \quad$ Policy Recommendations}

Based on our empirical and theoretical work, we have formulated some policy recommendations to address the main shortcomings of existing national policies. While different with respect to the wider contexts and the specific fields of activity, both stories have several important cross-cutting dimensions that could serve as foundations for public policy recommendations.

\subsection{Reconceptualising "Local Community"}

Existing policies have a static and rigid understanding of local communities. As we saw in both cases, existing legislation favours local authorities, thus it is the local mayor who decides whether a community should pursue a project or not. This is the reason alternative local actors (NGOs, SMEs, CSOs, informal citizen groups) are deprived of the possibility to participate and access financial resources to implement local projects. To change this situation we have to address the following challenges:

\subsubsection{Redefine Local Communities}

All policy initiatives that address rural communities have to enlarge their understanding of "community". Actors such as local SMEs, CSOs or local NGOs should be accepted to apply for governmental funding alongside or in cooperation with local authorities. Enlarging the number of elective actors can ensure wider participation of local communities, diversity of proposals and higher levels of approval for the projects to be implemented.

\subsubsection{Accessibility of Funding (EU and Governmental)}

Once the notion of community is widened, we have to make sure that all relevant actors have equal access to funding. In this respect, public policies that aim to encourage local community projects have to allow 
a wider range of actors to apply and benefit from funding. Moreover, we would argue that successful implementation of a community-owned project requires wide and diversified participation of local actors, and projects that bring together different community actors should be encouraged.

\subsection{Policymaking Is a Two-Way Street}

When discussing local development, we have to acknowledge the importance of local actors and the direct beneficiaries of public policy. The current policymaking structures in Romania and Hungary, which are guided by a top-down logic, have to be re-organised to put the perspective of local actors at the forefront.

An important change to the existing legislation would be to transform the policymaking process by means of a bi-directional mechanism primarily rooted in input from the local community. In order to ensure the required and timely input, any policymaking process should include local actors during three distinct stages: policy design, midterm evaluation and policy adaptation.

\subsubsection{Policy Design}

Before implementing such a change, we need to understand the resources and capacities of local actors. The existing policy discourse follows presumed causal models that are not connected to local realities. Given the fact that the processes of peripheralisation destroy social and human capital, we should engage experts to first focus on creating policies that contribute to the re-building of local human and social capital and then set the context for a participative policymaking process. Any policy encouraging local development first has to target the development of inclusive human and social capital by promoting knowledge generation at the local level.

Considering the lack or availability of local human capital, any policy on local development should start with public discussion of the initiative. Public debates should take place in communities targeted by the 
policy so that all possible stakeholders have the opportunity to influence the policy. With broad involvement of local actors, policymakers could succeed in acquiring the needed local knowledge and input while also ensuring wider public support.

\subsubsection{Policy Evaluation}

Following this initial phase, the primary beneficiaries of the policy should evaluate it. There could be different methods to collect feedback from local actors, but all those methods should rely on information from a wide range of actors. By involving the local community in policy review and evaluation, policymakers would secure feedback directly from the source and would have the possibility to compare locally sourced data with large- $\mathrm{N}$ statistical data.

\subsubsection{Policy Review and Change}

Based on such a midterm evaluation, policies should be revised and adapted and during this policy correction process local actors play a central role because they can provide feedback on the policy's effects and inside information on how to improve the efficiency of the policy.

By involving local actors in policymaking and review processes, the real needs of the community will be assessed accurately.

\section{Notes}

1. The name of the village was changed.

2. The name of the village and the actors of the initiative have been altered.

3. Anonymised citations are used to protect the anonymity of the case study selected.

4. Based on the interview (Interview, Kispatak, 23 March 2016) with the local mayor, the word "meaningful" was also used by him. 
5. Two of the 12 experts that we contacted referred to the village farm as an example of good practice in counteracting the processes of peripheralisation. When searching for the project on Google Scholar, we identified ten scientific articles that referred to the project as good practice, while six of the these ten articles argued that the initiative was socially innovative. Three different policy recommendations on social economy and sustainable rural development highlighted the farm as good practice.

6. A Best Practice Report was prepared and labelled "best practice" by Hungarian scholars and practitioners. It was aimed at decision-makers in the field of sustainable rural development.

7. Own compilation, based on KSH 2011 data and Kajner et al. (2013).

8. As a result, unemployment in the village $(4.35 \%)$ is lower than the national average (NGM 2015).

9. Apart from local municipalities, religious institutions and CSOs are also entitled to employ people through the government's Public Work Program (Frey 2007).

10. This chapter looks specifically at solar power projects. North-West Romania has the highest number of solar power projects implemented at the national level while solar power technology seems to be the most popular within the region as well. The high number of cases offers a good possibility for comparison and cross-case analysis. Complementary to that, the only two community owned REPs are also solar power projects.

11. Much of the electricity generated in Romania comes from hydropower plants. Even though hydro-generation is considered a renewable energy source, according to Romanian legislation only hydro-power plants with a maximum installed capacity of $10 \mathrm{MW}$ are entitled to the renewable energy support scheme. In this context, renewable energy in this chapter refers to all types of renewable energy sources, excluding hydro-power plants with an installed capacity greater than $10 \mathrm{MW}$ unless otherwise stated.

12. The government allocates green certificates to all registered production units that deliver renewable energy to the national grid. Producers can sell these certificates later on to suppliers of energy who have to prove that a part of their energy comes from renewable energy sources.

13. Oradea a city on the border with Hungary and the seat of Bihor county. 
14. Cluj-Napoca is the second biggest city in Romania and is the "unofficial" regional centre for the North-West region.

15. An association of local authorities (asociatie de dezvoltare intracomunitara) can also apply for financing. This association however is composed of local authorities, so in the end it is still the mayor who takes the final decision.

\section{References}

ADAS Consulting. 2003. "Renewable Energy and Its Impact on Rural Development and Sustainability in the UK." URN 03/886. Newcastle: ADAS Consulting for University of Newcastle. http://seg.fsu.edu/Library/ case $\% 20$ of $\% 20$ the $\% 20$ UK.pdf.

Amin, Ash, Angus Cameron, and Ray Hudson. 2002. Placing the Social Economy. London: Routledge.

Anonymised Source. 2011. A Monography on Kispataks Past, Present and Future, Written by Locals.

Anonymised Source. 2016. "Best Practices.” In Szociális Farmok létrehozása Magyarországon-Kézikönyv és fejlesztési javaslatok [Creating Social Farms in Hungary-Handbook and Policy Recommendations], edited by Péter Kajner and László Jakubinyi, 129-56. http://szocialisfarm.hu/files/ Szocialis\%20Farm\%20tanulmany\%203.2.\%20vegleges_nokorr.pdf.

Armstrong, Harvey, and Jim Taylor. 2000. Regional Economics and Policy, 3rd ed. London: Blackwell.

Becker, Sören, Conrad Kunze, and Mihaela Vancea. 2017. "Community Energy and Social Entrepreneurship: Addressing Purpose, Organisation and Embeddedness of Renewable Energy Projects." Journal of Cleaner Production 147: 25-36. https://doi.org/10.1016/j.jclepro.2017.01.048.

Benedek, József, and Aura Moldovan. 2015. "Economic Convergence and Polarisation: Towards a Multi-dimensional Approach." Hungarian Geographical Bulletin 64 (3): 187-203. https://doi.org/10.15201/ hungeobull.64.3.3.

Cebotari, Sorin, and Jozsef Benedek. 2017. "Renewable Energy Project as a Source of Innovation in Rural Communities: Lessons from the Periphery." Sustainability 9 (4): 509. https://doi.org/10.3390/su9040509. 
Cebotari, Sorin, Marius Cristea, Ciprian Moldovan, and Florin Zubascu. 2017. "Renewable Energy's Impact on Rural Development in Northwestern Romania." Energy for Sustainable Development 37: 110-23. https://doi. org/10.1016/j.esd.2017.02.002.

Ciepielewska-Kowalik, Anna, Bartosz Pielinski, Marzena Starnawska, and Aleksandra Szymanska. 2015. "Social Enterprise in Poland: Institutional and Historical Context." ICSEM Working Papers 11. https://www.iap-socent.be/sites/default/files/Poland\%20-\%20Ciepielewska-Kowalik\%20 et $\% 20$ al.pdf.

Crescenzi, Riccardo, and Andrés Rodríguez-Pose. 2011. "Reconciling TopDown and Bottom-Up Development Policies." Environment and Planning A: Economy and Space 43 (4): 773-80. https://doi.org/10.1068/a43492.

Csoba, Judit, and Zita Éva Nagy. 2011. "A magyarországi képzési, bértámogatási és közfoglalkoztatási programok hatásvizsgálata.” In Munkaerőpiaci Tükör, edited by Károly Fazekas and Gábor Kézdi, 113-45. Budapest: MTA Közgazdaságtudományi Intézet, Országos Foglalkoztatási Közalapítvány.

Cuellar, Amanda D. 2012. "Plant Power: The Cost of Using Biomass for Power Generation and Potential for Decreased Greenhouse Gas Emissions." Master thesis, Massachusetts Institute of Technology. https://sequestration. mit.edu/pdf/AmandaCuellar_Thesis_June2012.pdf.

Czike, Klára. 2011. “A kövesút végén. A területi egyenlőtlenségek csökkentése és a romák helyzetének javítása. Jelentés az LHH Program első szakaszának eredményeiről.” Nyílt Társadalom Alapítvány. https://www.opensocietyfoundations.org/sites/default/files/where-paved-road-ends-hungarian-20110301.pdf.

Defourny, Jacques, and Marthe Nyssens. 2014. "The EMES Approach of Social Enterprise in a Comparative Perspective." In Social Enterprise and the Third Sector. Changing European Landscapes in a Comparative Perspective, edited by Jacques Defourny, Lars Hulgård, and Victor A. Pestoff, 42-65. London: Routledge.

Del Rio, Pablo, and Mercedes Burguillo. 2008. "Assessing the Impact of Renewable Energy Deployment on Local Sustainability: Towards a Theoretical Framework." Renewable and Sustainable Energy Reviews 12 (5): 1325-44. https://doi.org/10.1016/j.rser.2007.03.004.

Directiva 2009/28/CE a Parlamentului European și a Consiliului din 23 aprilie 2009 privind promovarea utilizării energiei din surse regenerabile, de modificare și ulterior de abrogare a Directivelor 2001/77/CE și 2003/30/ 
CE. http://eur-lex.europa.eu/LexUriServ/LexUriServ.do?uri=OJ:L:2009:14 0:0016:0062:RO:PDF.

Dusek, Tamás, Réka Lukács, and Irma Rácz. 2014. "Development Differences Among the Regions of Hungary." Procedia Economics and Finance 9: 26477. https://doi.org/10.1016/S2212-5671(14)00028-8.

Eurostat. 2016. 17 October: International Day for the Eradication of Poverty-The Share of Persons at Risk of Poverty or Social Exclusion in the EU Back to Its Pre-Crisis Level—Contrasting Trends Across Member States. Available at http://ec.europa.eu/eurostat/documents/2995521/7695750/ 3-17102016-BP-EN.pdf/30c2ca2d-f7eb-4849-b1e1-b329f48338dc. Last accessed on 26 April 2018.

Evans, Mel, and Stephen Syrett. 2007. "Generating Social Capital? The Social Economy and Local Economic Development." European Urban and Regional Studies 14 (1): 55-74. https://doi.org/10.1177/ 0969776407072664.

Eversole, Robin, Jo Barraket, and Belinda Luke. 2014. Social Enterprises in Rural Community Development. Community Development Journal 49 (2): 245-61. https://doi.org/10.1093/cdj/bst030.

Fekete, Éva G., László Hubai, Julianna Kiss, and Melinda Mihály. 2017. "Social Enterprise in Hungary." ICSEM Working Papers 47. https://www. iap-socent.be/sites/default/files/Hungary\%20-\%20Fekete\%20et\%20al.pdf.

Fischer-Tahir, Andrea, and Matthias Naumann. 2013. "Introduction: Peripheralization as the Social Production of Spatial Dependencies and Injustice." In Peripheralization: The Making of Spatial Dependencies and Social Injustice, edited by Andrea Fischer-Tahir and Matthias Naumann, 9-26. Wiesbaden: Springer.

Frey, Mária. 2007. "A szociális gazdaság megjelenése a hazai fejlesztési stratégiákban és programokban.” In Szociális gazdaság kézikönyv, edited by Judit Csoba, Mária Frey, Éva G. Fekete, Márta Lévai, and Anikó Soltész, 164-78. Budapest: Országos Foglalkoztatási Közalapítvány.

Gébert, Judit, Zoltán Bajmócy, György Málovics, and György Pataki. 2016. "Eszközöktől a jóllétig. A helyi gazdaságfejlesztés körvonalai a képességszemléletben." Tér és Társadalom-Space and Society 30 (2): 23-44. https://doi. org/10.17649/TET.30.2.2752.

Government Decree (17 November 2007): No. 311/2007. (XI. 17.) A kedvezményezett térségek besorolásáról. In Magyar Közlöny 156, 11170-71. Last accessed 29 November 2016. 
Hanley, Nick, and Ceara Nevin. 1999. "Appraising Renewable Energy Developments in Remote Communities: The Case of the North Assynt Estate, Scotland." Energy Policy 27 (9): 527-47. https://doi.org/10.1016/ S0301-4215(99)00023-3.

Hargreaves, Tom, Sabine Hielscher, Gill Seyfang, and Adrian Smith. 2013. "Grassroots Innovations in Community Energy: The Role of Intermediaries in Niche Development." Global Environmental Change 23 (5): 868-80. https://doi.org/10.1016/j.gloenvcha.2013.02.008.

Harkai, Nóra. 2006. Közösség és közösségi munka. Budapest: VEL Kft.

Kabai, Gergely, Judit Keller, and Nándor Németh. 2012. "A foglalkoztatás növelésének célja a kormányzati célok rendszerében. Kistérségi fejlesztések." In Nyugdij, segély, közmunka. A magyar foglalkoztatáspolitika két évtizede, 1990-2010, edited by Károly Fazekas and Scharle Ágota, 47-62. Budapest: Budapest Szakpolitikai Elemző Intézet és MTA KRTK Közgazdaságtudományi Intézet. http://econ.core.hu/file/download/20evfoglpol/kotet. pdf.

Kajner, Péter, András Lányi, András Takács-Sánta, Béla Munkácsy, Gábor Bertényi, Attila Králl, György Jakab, Borbála Karády, Janka Horváth, Emese Bagoly, Máté Vámossy, Patrícia Hegedűs, Gergely Halász, Erzsébet Forrai, Gergely Horváth, Csilla Korinna Benke, Alexandra Tóth, Katalin Kovács. 2013. A fenntarthatóság felé való átmenet jó példái MagyarországonGood Examples of Transition Towards Sustainability in Hungary. MIS-ÖKO Kft. http://humanokologia.tatk.elte.hu/wp-content/uploads/a fenntarthatosag_fele.pdf.

Katonáné Kovács, Judit, Eszter Varga, and Gusztáv Nemes. 2017. "Fókuszban a társadalmi innováció folyamata a magyar vidéken [The Process of Social Innovation-Hungarian Case Studies of Rural Regions]." Északmagyarországi Stratégiai Füzetek-Northern Hungarian Strategic Papers 14 (1): 6-19. http://www.strategiaifuzetek.hu/files/85/Strategiai\%20 fuzetek\%202017-1.pdf.

Keller, Judit. 2011. "Heterarchia és fejlődési pályaváltás. Új elméleti megközelítés a kistérségkutatásban.” Tér és Társadalom-Space and Society 25 (3): 3-26.

Kesby, Mike. 2005. "Retheorizing Empowerment-Through-Participation as a Performance in Space: Beyond Tyranny to Transformation." Journal of Woman in Culture and Society 30 (4): 2037-65. http://doi.org/bsmvw9.

Koós, Bálint. 2015. "A szegénység és depriváció a magyar településállományban az ezredfordulót követően - avagy kísérlet a települési deprivációs index 
létrehozására." Tér és Társadalom-Space and Society 29 (1): 53-68. http:// doi.org/10.17649/TET.29.1.2681.

Kovách, Imre. 2012. A vidék az ezredfordulón. Argumentum, MTA Társadalomtudományi Kutatóközpont (Szociológiai Intézet): A jelenkori magyar vidéki társadalom szerkezeti és hatalmi változásai. Budapest.

Kovács, Katalin. 2010. "Social and Administrative Crises Interlocking: The Misery of Rural Peripheries in Hungary." Eastern European Countryside 16: 89-113. https://doi.org/10.2478/v10130-010-0005-5.

Kovács, Katalin. 2012. “A Cél a 'kiegyenlítés'. Falvakról, térbeli-társadalmi polarizációról, Enyedi Györgyre emlékezve.” Területi Statisztika 15 (52/6): 570-82.

Központi Statisztikai Hivatal (KSH). 2013. 2011 évi népszámlálás. 3. Országos Adatok. Available at https://www.ksh.hu/docs/hun/xftp/idoszaki/ nepsz2011/nepsz_orsz_2011.pdf. Last accessed on 26 April 2018.

Kühn, Manfred. 2015. "Peripheralization: Theoretical Concepts Explaining Socio-Spatial Inequalities." European Planning Studies 23 (2): 367-78. https://doi.org/10.1080/09654313.2013.862518.

Legea 220 din 27/10/2008 pentru stabilirea sistemului de promovare a producerii energiei din surse regenerabile de energie. In MONITORUL OFICIAL nr. 577 Din 13 August 2010. http://leg-armonizata.minind.ro/ leg_armonizata/energie/pdf/Legea_220_2008_R_28102011.pdf.

Lewis, Patrick J. 2011. "Storytelling as Research/ Research as Storytelling." Qualitative Inquiry 17 (6): 505-10. https://doi.org/10.1177/10778004 11409883.

Mészáros, Zsuzsa. 2013. "Közösségi gazdaságfejlesztés a gyakorlatban.” ACTA MEDSOC 4: 91-106. https://doi.org/10.19055/ams.2013.4/8-9/8.

Mihály, Melinda. (in review). "Opposing Peripheralization Through Community-Centered Local Development?-Case Studies from Hungary." ACME: An International Journal for Critical Geographies 15 (1): 129-49.

Nagy, Erika, Judit Timár, Gábor Nagy, and Gábor Velkey. 2015. "The Everyday Practices of the Reproduction of Peripherality and Marginality in Hungary." In Understanding Geographies of Polarization and Peripheralization. Perspectives from Central and Eastern Europe and Beyond, edited by Thilo Lang, Sebastian Henn, Wladimir Sgibnev, and Kornelia Ehrlich, 135-55. New Geographies of Europe. Basingstoke: Palgrave Macmillan.

NGM. 2015. Nemzetgazdasági Minisztérium/Regisztrált munkanélküliek adatai/2015. www.teir.hu. 
OECD. 2012. "Linking Renewable Energy to Rural Development." Executive Summary. Brief for Policy Makers. OECD Green Growth Studies. Paris: Public Governance and Territorial Development Directorate. http://dx.doi. org/10.1787/9789264180444-en.

Organismul Intermediar Pentru Energie. 2010a. "Cerere de propuneri de proiecte. Pentru asistenta financiara nerambursabila acordata din fondurile programului operational sectorial 'Cresterea competitivitatii economice', cofinantat din fondul european de dezvoltare regionala." http://old.fonduri-ue.ro/poscce/fonduri_structurale/pdf/Cerere_propuneri_proiecte_RES_ apel_2010.pdf.

Organismul Intermediar Pentru Energie. 2010b. "Ghidul Solicitantului." Sprijin financiar acordat pentru proiectele de investiţii în valorificarea resurselor regenerabile de energie pentru producerea energiei verzi în cadrul Axei 4 a Programului Operaţional Sectorial Creşterea Competitivităţii Economice. http://old.fonduri-ue.ro/poscce/fonduri_structurale/pdf/Ghid_ IMA_final_martie_2010.pdf.

Pénzes, János. 2015. “A kedvezményezett térségek lehatárolásának aktuális kérdései." Területi Statisztika 55 (3): 206-32.

Pike, Andy, Andrés Rodríguez-Pose, and John Tomaney. 2006. Local and Regional Development. Abingdon: Routledge.

Pike, Andy, Andrés Rodríguez-Pose, and John Tomaney. 2007. "What Kind of Local and Regional Development and for Whom?” Regional Studies 41 (9): 1253-69.

Sen, Amartya. 1999. Development as Freedom. Oxford: Oxford University Press.

Seyfang, Gill, Jung Jin Park, and Adrian Smith. 2013. A Thousand Flowers Blooming? An Examination of Community Energy in the UK. Energy Policy 61: 977-89. https://doi.org/10.1016/j.enpol.2013.06.030.

Transelectrica. 2015. "Contracte de Racordare." http://www.transelectrica.ro/ documents/10179/45094/7productie16.xls/8cac352d-676a-4fbb-9f1130e8d56a1d4d. Accessed 3 March 2016.

Váradi, Mónika Mária. 2016. “Értékteremto közfoglalkoztatás periferikus vidéki terekben.” Esély (1): 30-56. http://esely.org/kiadvanyok/2016_1/2016-1_2-1_Varadi_Ertekteremto_kozfoglalkoztatas.pdf.

Walker, Gordon, and Patrick Devine-Wright. 2008. "Community Renewable Energy: What Should It Mean?” Energy Policy 36 (2): 497-500. https://doi. org/10.1016/j.enpol.2007.10.019. 
Winter, Amanda K. 2016. "Environmental Sustainability? We Don't Have That Here: Freetown Christiania as an Unintentional Eco-Village." ACME: An International Journal for Critical Geographies 15 (1): 129-49.

Zolnay János. 2013. "Tartós munkapiaci kirekesztés, szegénység és társadalompolitikai válaszok-A kutatás kontextusa.” In A szociális segély csökkentésének hatásai a vidéki Magyarországon, 2012-Interdiszciplináris dokumentáció, edited by Katalin Nagy. Budapest: Pro Cserehát Egyesület. http://www.pillangokutatas.bffd.hu/kutatasi-eredmenyek/tanulmanyok.

Open Access This chapter is licensed under the terms of the Creative Commons Attribution 4.0 International License (http://creativecommons. org/licenses/by/4.0/), which permits use, sharing, adaptation, distribution and reproduction in any medium or format, as long as you give appropriate credit to the original author(s) and the source, provide a link to the Creative Commons license and indicate if changes were made.

The images or other third party material in this chapter are included in the chapter's Creative Commons license, unless indicated otherwise in a credit line to the material. If material is not included in the chapter's Creative Commons license and your intended use is not permitted by statutory regulation or exceeds the permitted use, you will need to obtain permission directly from the copyright holder.

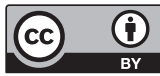




\title{
12
}

\section{Bypassing Structural Shortcomings:} Innovative Firms in Peripheral Regions

\author{
Martin Graffenberger
}

\section{Introduction}

This chapter investigates the innovation activities of two low-tech manufacturing firms located in South Estonia and the Erzgebirgskreis in Saxony (Germany). These settings, facing population decline, relative economic stagnation and a geographical outside location, are referred to as peripheral regions in the context of this chapter. The conceptual point of departure relates to the question of how firm-internal capacities and network linkages drive firm innovation, coexist and operate as mechanisms to circumvent the structural shortcomings of regional settings. Informed by dominant theoretical debates in economic geography and innovation studies peripheral regions are widely perceived as lacking the potential for sophisticated firm innovation. Departing from the concept of agglomeration advantages (van

M. Graffenberger $(\bowtie)$

Leibniz Institute for Regional Geography, Leipzig, Germany

(C) The Author(s) 2019

T. Lang and F. Görmar (eds.), Regional and Local Development 
der Panne 2004), the understanding is that a critical mass of relevant actors and resources drive firm innovation. Thus, dense metropolitan regions in which diverse actors and heterogeneous functions concentrate provide the most conducive conditions for innovation (Tödtling and Trippl 2005). They constitute productive arenas for face-to-face interaction and thereby for the exchange of spatially sticky tacit knowledge (Gertler 2003). These perspectives emphasise distinctive agglomeration arguments within the debate on knowledge, innovation and space (Ibert 2007), thereby implicitly and explicitly portraying larger city regions as innovation hotspots (Florida et al. 2017). Nonetheless, recent scholarship affirms that innovative firms also reside in peripheral regions (e.g. Rodríguez-Pose and Fitjar 2013; Grillitsch and Nilsson 2015), suggesting their capacity to bypass thin regional environments and to moderate the additional complexities they might induce. This chapter presents two in-depth investigations of innovation projects ('zooming in') and links their particular findings to the wider empirical basis of the research project ('zooming out'). Thereby, this chapter adds to emerging accounts on innovation in peripheral settings and provides insights that allow us to better understand how firms located in peripheral regions pursue and organise innovation activities.

\section{Conceptualising Firm Innovation}

Baregheh et al. (2009, 1334) define innovation as the 'multi-stage processes whereby organisations transform ideas into new/improved products, services and processes'. Departing from this definition, three theoretical building blocks constitute the understanding of innovation adopted in this chapter and will be briefly outlined in the following paragraphs: process orientation, knowledge foundation and interaction. The two latter aspects form the basis for a more elaborate conceptual discussion that informs the chapter's analytical perspectives (Fig. 1).

The process nature of innovation involves a particular evolutionary understanding. Innovation is directed by the state-of-the art in respective fields and builds, to varying degrees, on existing capacities 


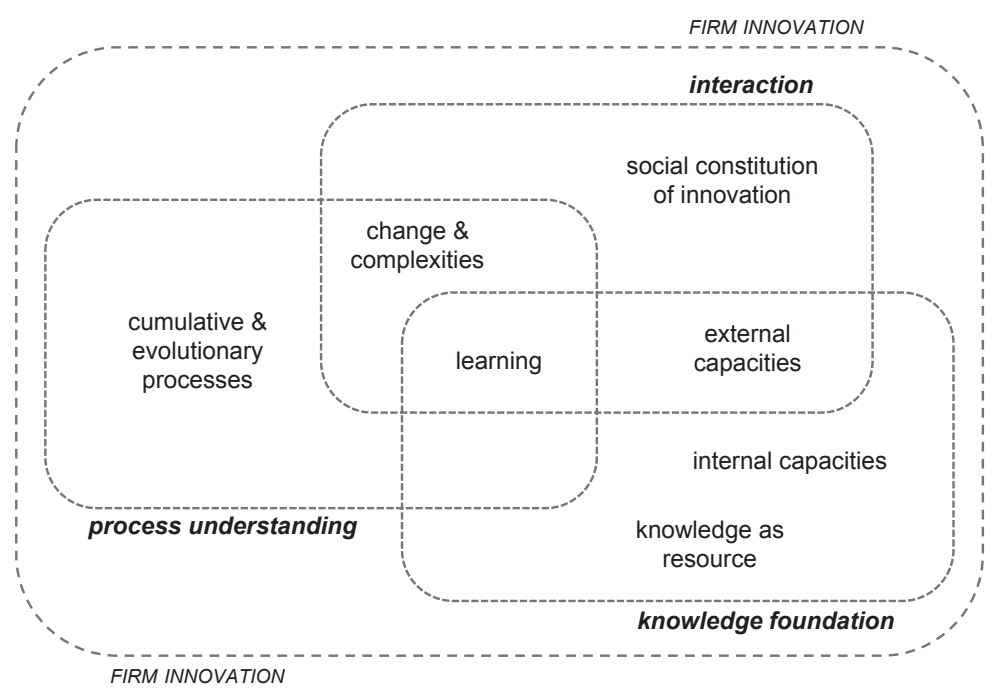

Fig. 1 Conceptualising firm innovation (own elaboration)

and awareness levels of the organisations and individuals involved. Consequently, organisations build capacities and progress in their respective markets by pursuing innovation activities (Fagerberg 2006).

Innovation-centred debates in economic geography highlight the critical role knowledge takes on in associated transformation processes. This knowledge foundation relates to learning processes which are considered key for successful innovation (Gilly and Torre 2000). The shift towards an increasingly knowledge-based economy (Lundvall and Johnson 1994) corroborates the function of knowledge as the central resource and in particular the premium assigned to highly contextualised tacit knowledge (Gertler 2003). This knowledge grounded nature of innovation is driven by resources and capacities internal and external to firms (Edquist 2006).

Acquisition of external capacities links up with the interactive nature of innovation. Confronted with increasing complexities, innovation does typically not happen in isolation (Fagerberg 2006; Shearmur 2012). Interaction is pivotal for successful innovation as it provides 
access to external resources that help to moderate associated complexities (Nonaka 1994). Furthermore, interactivity provides a lens to consider innovation as social, cultural and relational practice (Malecki and Tootle 1996; Welz 2003). The following sections provide a brief conceptual discussion by linking these theoretical building blocks to the notions of firm-internal capacities and networks.

\subsection{Internal Capacities}

The critical role of firm-internal capacities for knowledge creation, learning and innovation is frequently emphasised (e.g. Edquist 2006). It is widely accepted that firm competitiveness is significantly driven by internal resources and how they are coordinated (Taylor and Asheim 2001). Firms can be perceived as unique bundles of resources such as technological capabilities, production experiences and organisational routines, specific human resources or the existing customer base which collectively ensure competitiveness (Foss 1997; Flåten et al. 2015). Thus, firms become generators and processors of knowledge that draw capacities from embedded learning and the particular routines that shape the distinct characteristics of firms' knowledge bases (Taylor and Asheim 2001). Concerning the focus of this contribution on firms operating from peripheral, i.e. structurally challenging regional settings, it can be argued that firm-internal resources are of great importance for maintaining innovative capacity, as firms cannot rely so much on rich and diverse resources available locally.

However, while substantially driving innovation, firm-internal capacities alone are not sufficient. Relations for instance to suppliers and customers, research and educational institutions, state agencies and chambers are considered central mechanisms through which firms access external resources and expertise. Yet, the capacity of firms to recognise and internalise external knowledge from different sources and localities is understood to rely on their internal capacities (Cohen and Levinthal 1990). 


\section{$2.2 \quad$ Networks}

Firm networks can be broadly defined as 'nodes and links connecting these nodes, in order to facilitate interactions among agents' (Johansson and Quigley 2003, 165). Networks are constituted by complex interactions amongst individuals and organisations and considered resources-rich arrangements (Copus and Skuras 2006). Networks provide central means to access external knowledge and mediate complexities, thereby becoming fundamental aspects of innovation-related practices (Rammert 1997; Fitjar and Rodríguez-Posé 2016). Malecki and Tootle (1996) suggest a pragmatic distinction between trade networks, concerned with formalised exchange of goods and services, and knowledge networks, constituted by flows of information and knowledge. Knowledge-intensive and learning-oriented linkages between partners are in particular understood to ground on high degrees of reciprocity and trust and, thus, to induce mutually active partnership (Ozman 2009). Although distinctions between different types of network ties appear analytically useful, trade and knowledge related links might overlap in reality. Firms are embedded into various overlapping and mutually influencing contexts which surface as multi-layered relations and interactions of various kinds. It is therefore proposed to perceive networks systemically, as coordinated and ongoing sets of economic and non-economic relations (Dubois 2013). This understanding implies an inherently dynamic and fluid nature of networks: new links between actors evolve, existing links reproduce, alter or might disappear over time (Ter Wal and Boschma 2009).

Network perspectives allow us to shed light on how actors interact in and with their various environments and, importantly, how actors construct their specific environment(s) needed for innovation (Jakobsen and Lorentzen 2015). This chapter explores the linkages and networks firms from peripheral regions mobilise as part of their innovation endeavours. For these firms, networks are considered potential means to compensate for structural shortcomings of regional settings such as lacking agglomeration advantages (Johansson and Quigley 2003). Thereby, networks offer an approach to extend the role of geographical proximity and actor 
co-location, prominently inscribed in influential conceptions of dynamic regional economies (Moulaert and Sekia 2003), with spatially less restrictive perspectives. This chapter does not deny the potentially easing role of co-location and face-to-face interaction for knowledge creation and innovation. However, it is increasingly recognised that actor proximity can also be organised temporarily or virtually without compromising interaction quality (Torre 2008; Maskell 2014). More recently it also has been suggested that the interaction requirements of firms differ and that firms with lower interaction needs might choose to reside outside dense city regions (Shearmur and Doloreux 2016).

\section{Methods and Data}

This chapter mostly draws on interviews with firm representatives. Inspired by the innovation biographies approach (Butzin and Widmaier 2016) interviews explored concrete innovation projects. Interviews with individuals from the management level (CEOs, technical managers, etc.) grant access to information on decision-making and strategic considerations. To ensure direct observation, interviews were conducted in the workplace of respondents. Descriptions provided by interviewees were enriched and validated by triangulating data from media coverage and internet sources. The empirical material was used to reconstruct central elements and assertive dynamics of investigated innovation projects.

The analytical proceedings of this study rely on a multiple-case approach (Yin 2014), i.e. detailed investigations which shed light on the main phenomenon of interest (innovation) and the specific contexts in which this phenomenon occurs. Studying multiple cases in-depth allows us to detect similarities and differences, reduces the risk of chance associations, and thereby increases the scope for analytical generalisation (Eisenhardt 1989). Following an embedded case design, this chapter integrates the unit of specific innovation projects as well as the firm level. Variation sampling was used to construct a heterogeneous sample of different types of innovative firms located in differently structured peripheral settings, potentially allowing to draw conclusions beyond the contingencies adhering to individual cases. 


\section{$4 \quad$ Research Contexts: Regional Starting Points and Low-Tech Manufacturing}

The cases investigated as part of this chapter are located in different regional contexts, the Erzgebirgskreis in Saxony (Germany) and South Estonia. ${ }^{1}$ Maps 1 and 2 provide overviews on the case study regions and the location of cases. Although differently structured the study regions share, with reference to their respective macro contexts, exposure to socioeconomic challenges such as population decline, relative economic stagnation and a geographical outside location (see Table 1). Following Kühn et al. (2016), such challenges are considered indications of ongoing peripheralisation processes.

Both study regions are characterised by long traditions of manufacturing industries which continue to provide a major economic base. The significance of manufacturing corresponds to a relatively low importance of service sectors. Most relevant manufacturing activities in the Erzgebirgskreis, formerly an important mining region, are metal production and processing, mechanical and electrical engineering as well as food processing. Case 1 in Sect. 5.1 illustrates an innovation project by a shaving equipment manufacturer. It relates to the historical legacy of the brush-making industry within this part of the Erzgebirge, which can be traced back to the eighteenth century. During its peak in the nineteenth and twentieth century, the region hosted multiple brush manufacturers, including small family businesses and large manufacturers. Up until today, a number of companies active in brush- and broom-making reside within the region. Structurally important industries in South Estonia are wood processing, furniture manufacturing, electronics and the food sector. Additionally, forestry and agriculture retain importance in South Estonia with its share in value added exceeding 14\%. Case 2 in Sect. 5.1 presents an innovation project implemented by a company from the food sector.

Given the importance of manufacturing activities in both study regions, the sectoral focus is on innovation in low-tech and medium low-tech (LMT) manufacturing. Although not necessarily on top of innovation policy agendas, LMT manufacturing continues to have substantial economic importance and is, e.g. through buyer-supplier 


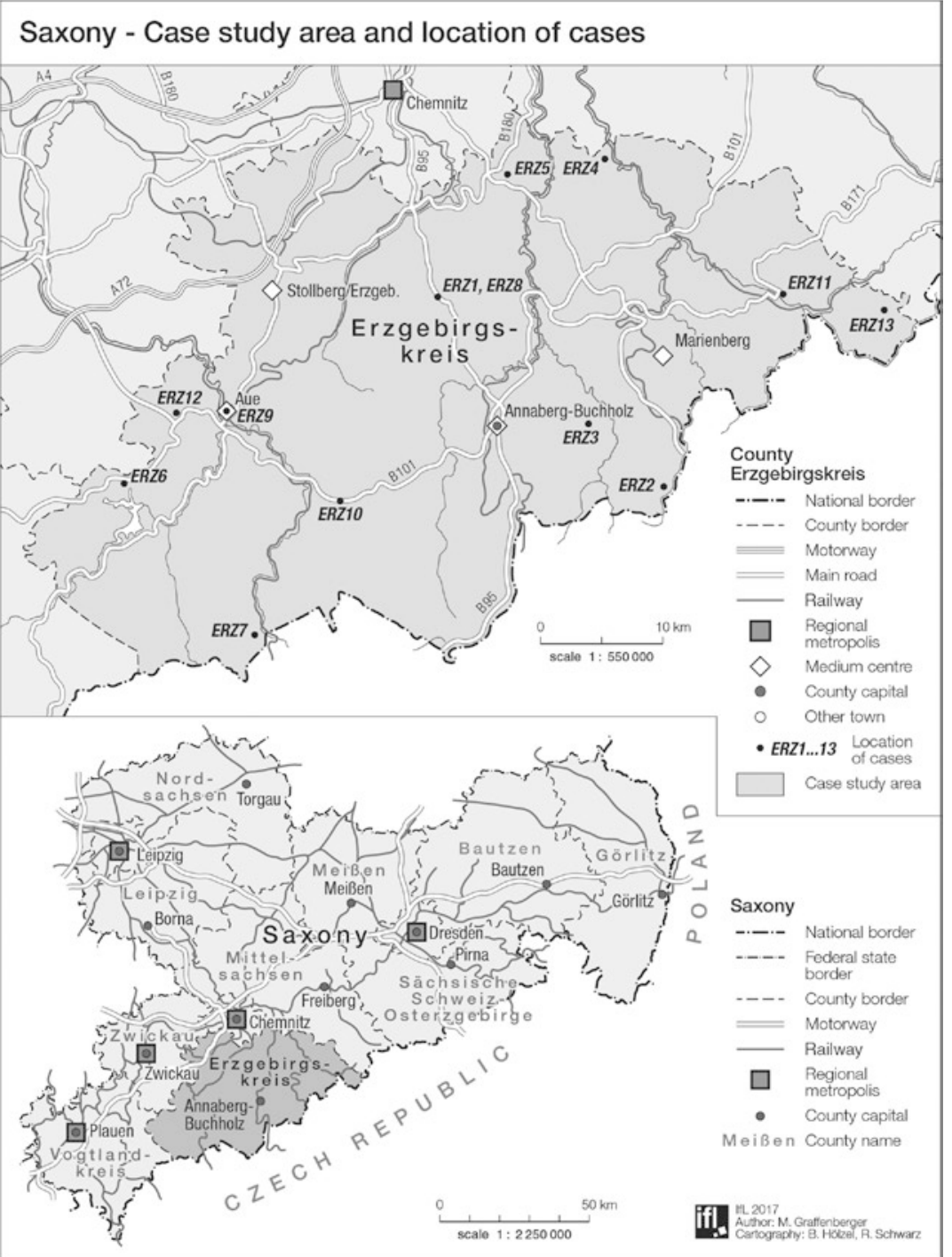

Map 1 Case study area and location of cases in the Erzgebirgskreis 


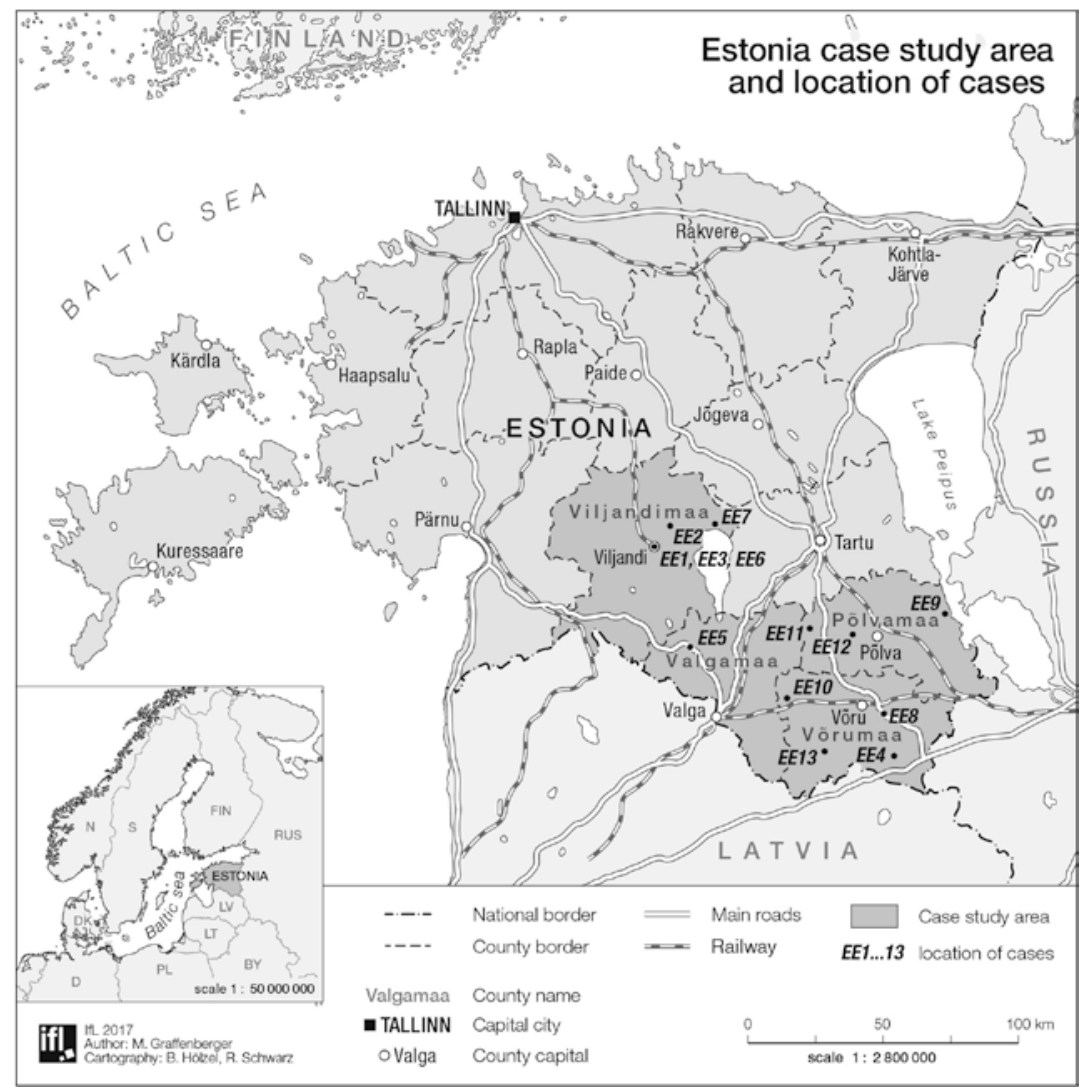

Map 2 Case study areas and location of cases in South Estonia

relations, highly interwoven with high-tech industries (Hansen and Winther 2011). Due to the characteristics of innovation in LMT manufacturing, e.g. generation of incremental rather than disruptive innovation, focus on experienced-based knowledge rather than science and R\&D (Hirsch-Kreinsen 2008), the innovation capacities of LMT sectors appear 'overlooked and possibly misjudged' (ibid., 12). Explicitly focusing on innovation in LMT manufacturing, the chapter addresses existing sectoral biases in innovation studies and provides insights into the innovation dynamics of activities that bear economic relevance for many peripheral regions. 


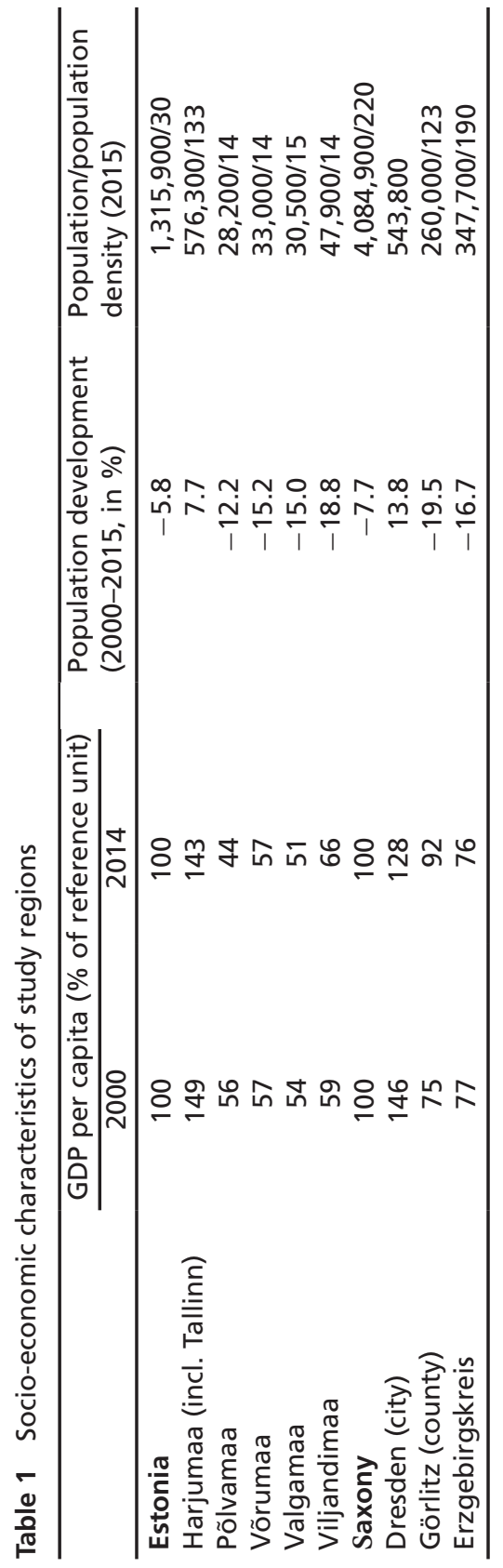




\section{$5 \quad$ Firm Strategies and Practices}

This section presents detailed insights from two information rich cases studied as part of a wider research project. Case 1 from the Erzgebirgskreis draws on interaction with numerous external partners while the Estonian case exhibits just a few external linkages. Although both firms show differences along demographic indicators (see Table 2), associated knowledge bases and regional settings, the subsequent analysis reveals a number of similar mechanisms mobilised for innovation as well as implicit and explicit strategies to bypass certain shortcomings. Section 5.2 provides a discussion of the specific cases, and zooms out to draw a more comprehensive picture of findings by selectively referring to further cases investigated as part of wider research.

\subsection{Zooming In: Detailed Case Explorations}

\subsubsection{Case 1: MÜHLE ${ }^{2}$}

The company behind the MÜHLE brand was established in 1945 in the village of Hundshübel in the western part of today's Erzgebirgskreis. After expropriation in 1972, the firm was re-privatised in 1990. At the time of the interview MÜHLE, initially manufacturing shaving brushes but now producing a comprehensive range of shaving accessories, had 73 employees, annual sales of approx. 12.5 million EUR and an export ratio of $70 \%$.

Design quality, sustainability, manual production, family ownership and a high in-house production depth are portrayed as MÜHLE's main features and as crucial elements for maintaining its leading market position. Over the past 7-8 years, MÜHLE has experienced a period of dynamic growth during which turnover trebled. These dynamics are, amongst others, linked to the strategy of gradually expanding in-house production depth and the exploitation of new marketing potentials offered by the internet. Accordingly, MÜHLE extensively uses online marketing channels and social media. 


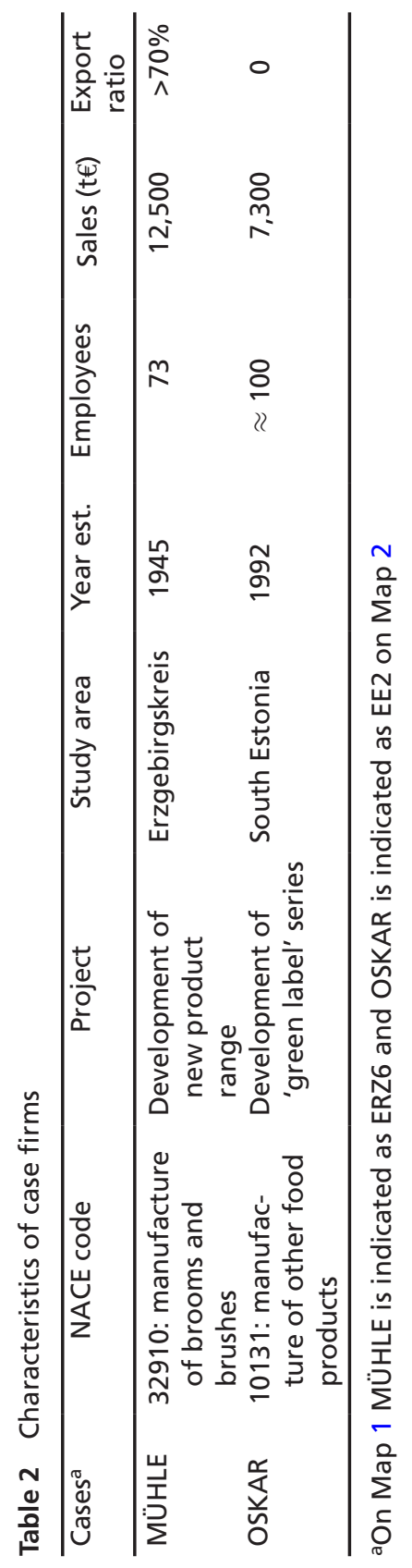




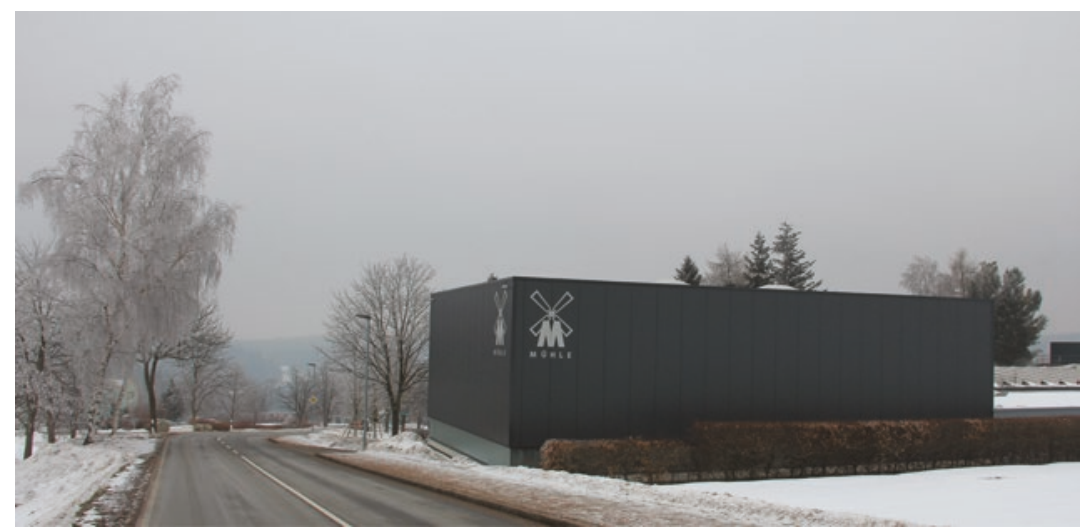

Picture 1 MÜHLE premises in Hundshübel (picture by author)

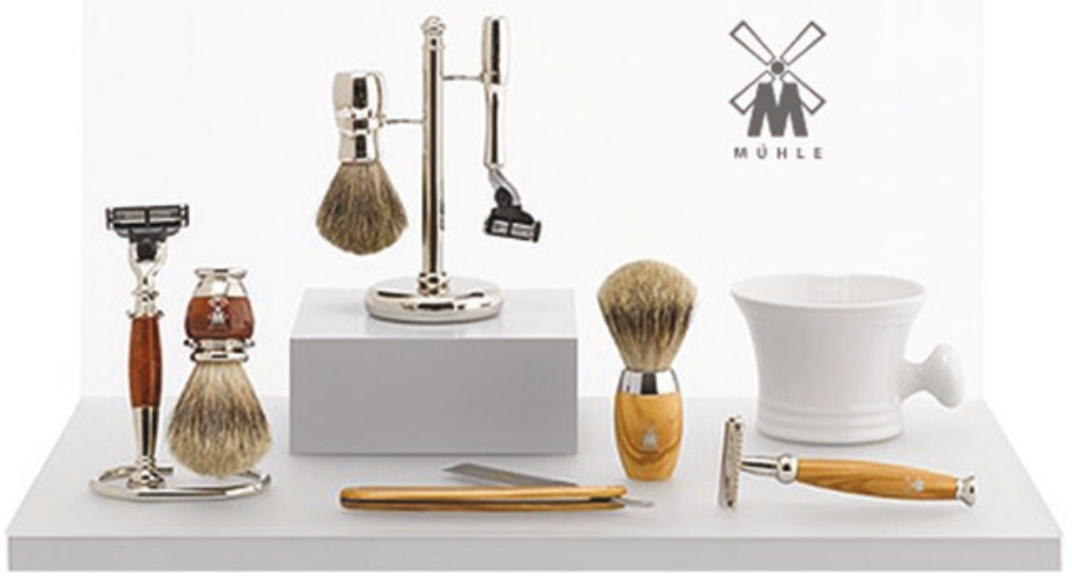

Picture 2 Illustration of MÜHLE's product range (courtesy by MÜHLE)

Developing a New Product Range

The CEO and co-owner depicts the innovation activities of the company as a 'marathon' during which various processes require coordination: e.g. monitoring and identification of market potentials and technological solutions, elaboration and implementation of design specifications, etc. Typically, innovation within MÜHLE draws on 
extensive monitoring and research activities in technology and design related fields, without necessarily having a precise product idea in mind. This case study investigates the development of a new product range. The origins of this innovation project can be traced back to long-term technology monitoring activities, lasting for 5-6 years. This monitoring was driven by intentions to reduce production costs and to widen sales opportunities by implementing new technology solutions. Metal injection moulding (MIM) replaced conventional machining methods in the manufacturing process of stainless steel parts, resulting in substantial cost reductions. Although MIM technology itself is long established, it is rarely applied for delicate design-oriented items — such as safety razors and shaving brushes. Accordingly, only a few companies master the complex technology for such specific applications.

After identifying the leading company in the field, based in BadenWürttemberg, MÜHLE engaged in a loose but mutually very open and rather long-lasting technical consultation process, involving repeated on-site visits and telephone communication. At this early stage, practical consulting with the leading player was considered crucial regarding learning about the technology and thereby identifying its potentials:

They showed me what is doable with the technology regarding decorative applications and I realised that this is indeed something future-oriented for us, potentially affecting wider parts of our product range. (Interview, Hundshübel, 9 February 2017)

Subsequently, it was decided to integrate MIM into the development of a new, stainless steel-based product range. In this context, an important decision by MÜHLE was to collaborate with a known local partner experienced in injection moulding-although using rather conventional plastics-based applications - to anchor the new technology within the region. This decision was guided by the rationale that being geographically close and familiar eases the handling of associated complexities and upcoming issues: 
We were very interested to establish the technology with a partner from the region $[\ldots]$. Although they didn't know the specific method, they were very interested, and we decided to go ahead together. [...] Because I see the potential for our wider product range, I thought it is good to proceed with a local partner. We know each other and we have short ways. (Interview, Hundshübel, 9 February 2017)

Collaborating with this local partner involved close coordination to find solutions for upcoming technical issues. During this process, the local technology partner further consulted with external actors. Based on continuous efforts of adapting the technology to the specific requirements needed, these joint activities induced successive learning, ultimately facilitating the launch of the new series in autumn 2016. Even though, due to some persistent technical issues, production started in 'homeopathic quantities'. At some point in the process of better understanding and adapting MIM technology, specifications for the new product series were elaborated. At this stage an industrial designer from Meißen (Saxony) with whom MÜHLE has an established and trusted relation, joined the development, closely liaising with both MÜHLE and the technology partner. The designer's contribution to the development concerned elaboration of the industrial design, thereby bringing in specific capacities such as CAD and 3D design applications. Coordination of these technological and design-related features between the different partners is described as a complementary 'ping-pong' game, suggesting frequent and iterative exchange, eased by familiarity and rather short distances between the partners. Thereby MÜHLE's goal to not only progress technologically but at the same time to create products with specific usability features were realised. Besides these central partners, the development further involved a supplier of birch bark. This material was perceived as a valuable component to create holistically innovative products, combining new technologies, new materials and a distinct, progressive design. The final partner, a manufacturer of specialised sand-blasting equipment based in the Chemnitz region, got involved in the surface finishing stage in the production process. Instead of outsourcing the finishing process to this partner, MÜHLE, 


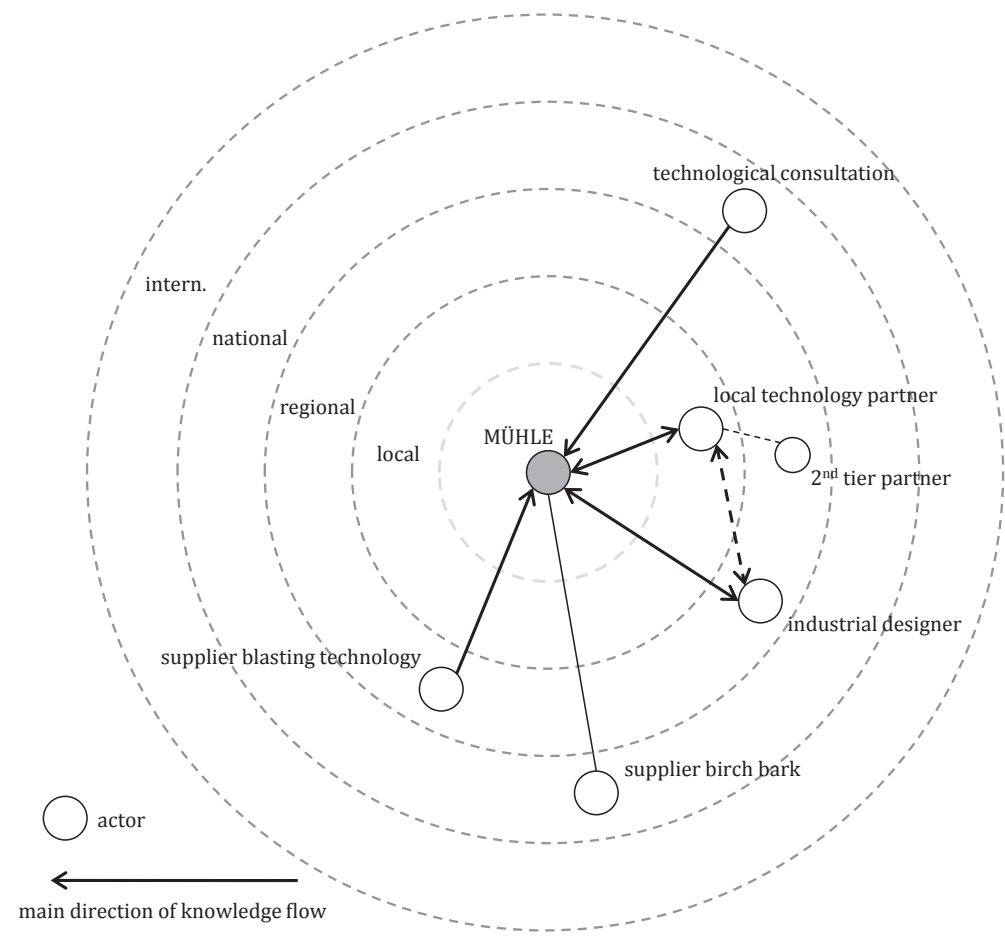

Fig. 2 Network map of MÜHLE's development

after consulting with the supplier, came to a financial arrangement to integrate the technology within the firm, thereby further expanding its specific in-house production depth. Figure 2 provides an ego-centred network map. ${ }^{3}$

\section{Firm-Level Strategies}

Going beyond this specific innovation process, the MÜHLE case provides additional insights in terms of wider firm strategies to bypass shortcomings of the regional environment. The interviewee links such shortcomings mainly to the notion of physical distance to larger cities/ main markets, considered central for marketing activities but also as sources of design-related inspiration: 
If our production were in Leipzig or Berlin, a lot more would be feasible in terms of co-operations, we would have more buzz in our showroom, we could host cultural events in our production facilities. This is more difficult here. (Interview, Hundshübel, 9 February 2017)

To compensate for these specific shortcomings MÜHLE has adopted a number of strategies related to widening the firm network. Firstly, comprehensive activities in terms of virtual and (social) media marketing were started (including an online shop, presences on Facebook and Instagram, a dedicated (printed) company magazine). Secondly, as a major piece of its marketing strategy MÜHLE opened a flagship store in Berlin in 2014, constituting in itself a significant organisational innovation by which market distance was reduced and the firm network expanded:

With the flagship store in Berlin we can reach people a lot easier and present as well as transport our brand very differently. (Interview, Hundshübel, 9 February 2017)

Additionally, high levels of mobility and membership in initiativessuch as the 'Association of German Manufactories' or the 'German Design Council'-ensure co-presence and exchange with relevant actors, customers and suppliers, as well as the influx of inspiration and ideas from various fields. At the same time, however, MÜHLE's location in the Erzgebirge plays a crucial role for brand identity and authenticity, succinctly expressed by the interviewee:

for me, MÜHLE only works here in the Erzgebirge, separating the two is somewhat unthinkable. (Interview, Hundshübel, 9 February 2017)

\subsubsection{Case 2: OSKAR ${ }^{4}$}

OSKAR, a meat processing company, was established in 1992 in the village of Saarepeedi in Viljandi County. OSKAR has around 100 employees and its sales of approx. 7.3 million EUR are exclusively 


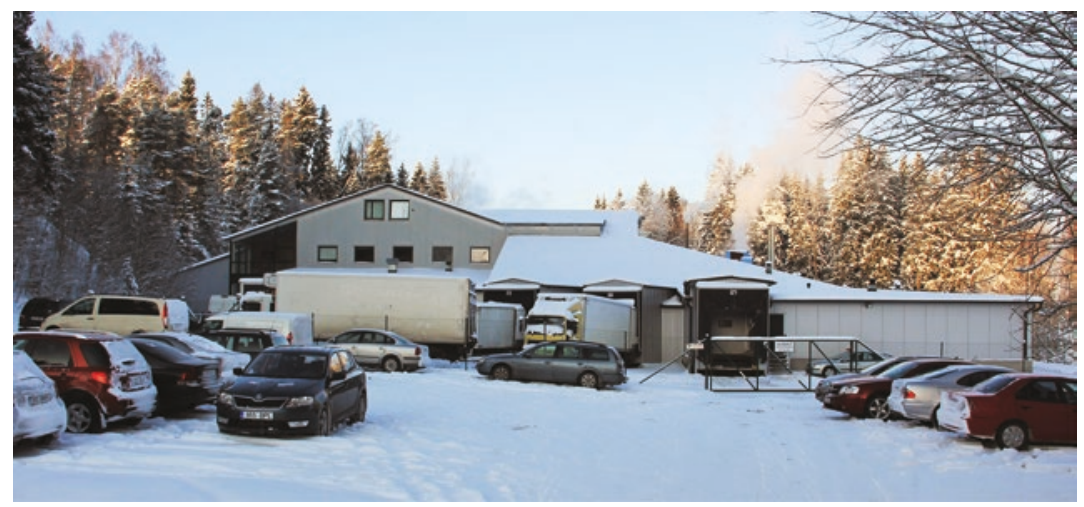

Picture 3 OSKAR premises in Saarepeedi (picture by author)

generated in Estonia. OSKAR is a small player in the highly competitive and de-regulated Estonian meat market which is largely dominated by Finnish companies/brands. Despite its small size, OSKAR is market leader in multiple product categories and has in the past frequently acted as a 'pioneer', by introducing new products in niches that were eventually adopted by competitors and thereby diffused more widely. A recent strategic re-orientation has been a focus on high-priced products, resulting in substantially increased sales, while processed quantities remained stable. According to the interviewees, OSKAR further differentiates itself from competitors in a number of ways, e.g. by rejecting controversial technologies (such as $\mathrm{MSM}^{5}$ ) or by manufacturing products with high meat contents.

\section{Development of 'Green Label' Products}

The term 'green label' refers to a product assortment which does not contain artificial additives ('E-free'), first launched in 2009. ${ }^{6}$ The development was mainly driven by two intertwined factors: first, fierce competition in the Estonian meat market, which was facilitated for instance by using MSM technology to achieve lower prices, and, second, by having a public discourse on more healthy and natural nutrition. Within this field of tension products free of artificial additives were identified as a potential niche and considered a 'logical' progression for OSKAR, 
as the technological pre-requisites for such products closely aligned with OSKAR's manufacturing practices:

As we have never used MSM raw material, our products have anyway a high meat content. Which is what you need to produce E-free products. If you have too much fat, water or starch there is no way to keep the product in one piece. [...]. So removing E-numbers from products was a logical next step for us. (Interview, Saarepeedi, 14 January 2016)

Lacking specialised technological knowledge, OSKAR needed to acquire external technological knowledge, in particular natural substitutes for artificial additives and recipes for their application to kick-start development. Consequently, OSKAR went through an iterative consultancy process with different European suppliers, finally acquiring technology from a leading firm based in Germany. Key to successful product development was combining the technological tools acquired with internal practical knowledge and experiences, in particular of OSKAR's food technologists. Rather than acquiring a ready-to-use technology, substantial adaptations were necessary to meet the desired product specifications regarding taste, texture and visual appearance:

We had to accommodate components and recipes to our conditions, and sometimes we got different results. So we had to find ways to get good results. [...]. We had to combine their knowledge and our knowledge. [...]. We were testing every day to find out which compounds work. The components are not always working as sales representatives say, so you have to test and test all over again, which is time-consuming and expensive. (Interview, Saarepeedi, 14 January 2016)

This iterative firm-internal process took about six months, at the end of which the first product was finalised. Subsequently, the 'green label' assortment gradually expanded, with each of the individual products requiring specific iterative circles. Product development was followed by marketing activities, including elaboration of suitable packaging, creation of the indicative 'green label' and, importantly, the process of building trust and authenticity with consumers: 
There was a certain discussion with our first product, also from the media. They didn't understand the E-free products. [...]. It was hard for us to get the customers to trust our product, it maybe took a year until people accepted the concept. (Interview, Saarepeedi, 14 January 2016)

The launch of a 'green label' product assortment coincided with a gathering of the Estonian meat industry, during which products were presented. According to anecdotal evidence provided by the interviewees, competitors mostly reacted with incomprehension. However, this reaction illustrates the way OSKAR moved away from conventional industry practices, thereby opening a particular market niche. As the interviewees report, by now most competitors have introduced their own E-free product ranges. Figure 3 provides another ego-centred network map.

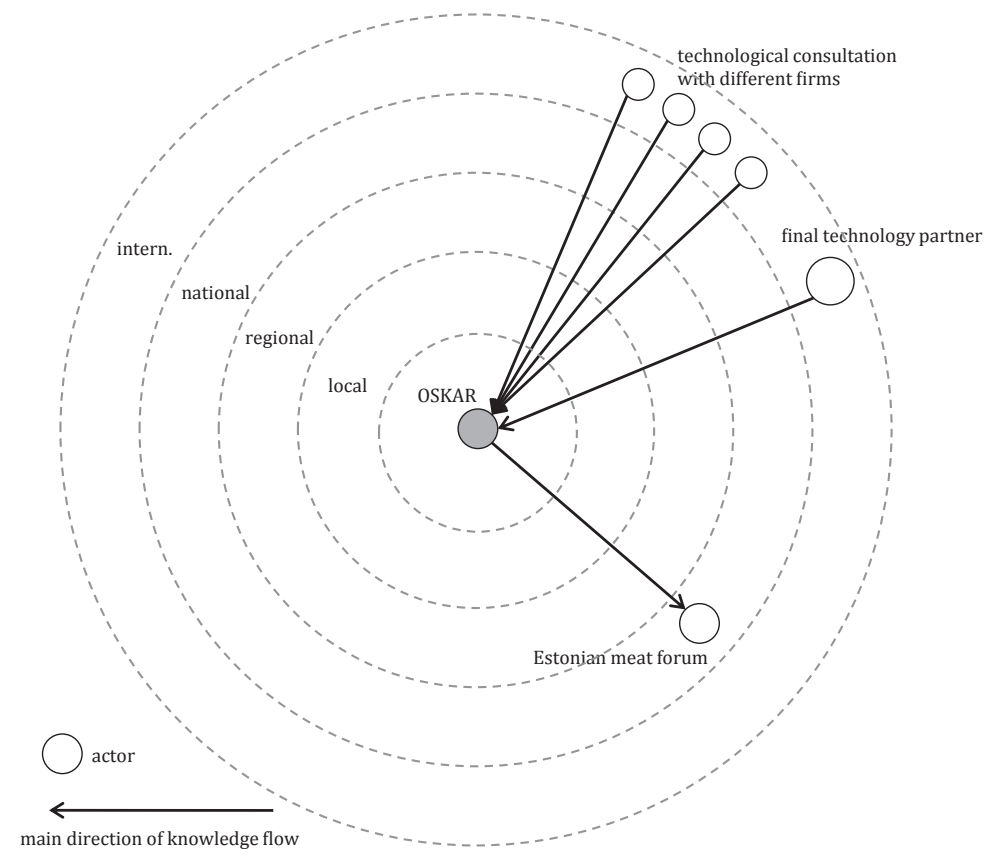

Fig. 3 Network map of OSKAR's 'green label' development 


\section{Firm-Level Strategies}

The 'green label' project illustrates the importance of firm-internal, practical expertise for effective assimilation of externally acquired knowledge. Going beyond the development outlined above, the importance of internal expertise is also evident at the wider firm level. In addition to emphasising the importance of specialised food technologists for product development, OSKAR's range of internal capacities also relates, for instance, to the construction of specific manufacturing equipment by technicians. These highlight the comprehensive in-house manufacturing depth available to OSKAR:

We even build our equipment. We have excellent guys in-house who produce equipment for new technologies. Thereby we can test at a small scale and then make larger equipment for producing larger quantities later on. (Interview, Saarepeedi, 14 January 2016)

Being exclusively active in the Estonian market, distance to its primary market Tallinn is described as somewhat problematic and associated with high transaction costs. At the same time, it is crucial to be visible on the Estonian market, despite having only limited resources for marketing. In this respect OSKAR's participation in national trade fairs (food and non-food related) and organising supermarket demos and tastings allows the firm to generate visibility and partially bridge the distances to main markets:

Trade fairs in Estonia are a good place for us to get in touch with endconsumers. There are lots of experts but also normal people who are simply interested in what we show. [...]. The main reason for us to go to fairs is to catch the end-consumer. (Interview, Saarepeedi, 14 January 2016)

\subsection{Zooming Out: Discussion and Cross-Case Reflections}

The illustration of two innovation projects of firms from different peripheral contexts underpins the importance of (i) network linkages to external partners to acquire knowledge/expertise and (ii) firm-internal 
capacities. Both appear as decisive and intertwined mechanisms that facilitate firms' innovation endeavours. Each of the cases presented reflects different facets on how this coupling might operate. MÜHLE mostly draws on acquiring specific technological expertise through purposefully built relations and further mobilises existing linkages to integrate this expertise into the firm. While internal capacities facilitate this integration process, network mechanisms prevail. In developing 'green label' products, OSKAR primarily utilises internal practice-based expertise to adapt externally acquired knowledge to its specific requirements. This coupling can be understood along the lines of Cohen and Levinthal's $(1990,128)$ conception of absorptive capacity which posits the capability of firms to 'recognise the value of new, external information, assimilate it, and apply it to commercial ends' as a critical innovation resource.

Considering the larger set of cases investigated as part of the wider research affirms the importance of diverse in-house production and experience-based capacities (e.g. ERZ1, ERZ2, ERZ3, ERZ7 | EE1, EE5, EE10) as well as their strategic expansion (e.g. ERZ3, ERZ13 | EE11) for maintaining competitiveness and innovation potential. For instance, ERZ2, a case manufacturer, maintains departments for model construction, mould making and a sewing unit-which, collectively, ensure a high level of in-house production capacities and, thereby, increase the firm's readiness to handle emerging requests flexibly. In addition to expanding technological capabilities as illustrated by the MÜHLE case, in-house production can further expand by internalising the preparation of technical drawings rather than buying them in as external services (EE11), or by establishing of new distribution channels directly targeting end-customers (e.g. ERZ3, ERZ13). Maintaining extensive and further diversifying in-house production capacities enhances flexibility and reduces dependency on external partners. Thereby, firms build self-sufficiency which complements the acquisition of innovation relevant knowledge from external and extra-regional sources. Thus, building internal capacities along various dimensions can be considered a strategy of firms from peripheral regions to compensate for lacking relevant knowledge available regionally, which, at the same time, reduces firms' interaction 
requirements. These indications confirm recent research by Flåten et al. (2015) who argue that strong internal capacities, built by workplace-learning, constitute central factors for the competitiveness of firms in 'thin' Norwegian regions. Consequently, this research contributes to a more nuanced understanding of the factors that shape the innovation capacity of firms from peripheral regions active in LMT manufacturing: the firms investigated as part of this study tend to rely on diverse and multifaceted internal capabilities, coupled with multi-scalar external linkages_-including local and non-local contacts. These observations deviate from the seemingly established norm on how innovation in contemporary knowledge economies is organised, i.e. by focusing on core-competencies and knowledge sourcing from local partners (Flåten et al. 2015). Nevertheless, as this research illustrates, these practices induce organisational learning-which in MÜHLE's case, by anchoring technological capacities within the region, expands to a distinct regional and inter-organisational dimension.

Focusing on the wider firm level reveals mechanisms by which firms manage distances to primary markets or knowledge sources. Such mechanisms operate for instance by establishing permanent outposts in relevant hotspots, or the generation of temporary co-presence via high levels of mobility and trade fair participation. Following Maskell's (2014) conceptualisation, MÜHLE's flagship store can, while being primarily a particular marketing tool, be understood as a 'listening post'. Such an observatory, strategically established as a subsidiary in one of the most relevant hotspots for MÜHLE (Berlin), offers the potential to identify relevant knowledge and informal information (e.g. specific demands, trends, perceptions, etc.) directly from consumers and industry players. It thereby contributes to the identification of relevant market developments. While such a flagship store certainly represents a special example, the importance of trade and consumer fairs is frequently referred to across cases. Besides their role regarding marketing, fairs are widely considered arenas to make contact and to source relevant knowledge (e.g. ERZ2, ERZ9, ERZ12 | EE1, EE3, EE4, EE7). For instance, during trade fairs, ERZ2, ERZ9 and EE4 established initial contacts with actors which, subsequently, became pivotal for 
innovation projects as either initiators (ERZ2, ERZ9) or collaboration partners (EE4). Therefore, it can be assumed that the peculiar ecology of such settings offers firms productive means to overcome distance and to benefit from organised and temporary centrality.

\section{Conclusions and Implications}

The empirical material presented in this chapter demonstrates that in order to maintain innovation capacity and competitiveness firms operating from peripheral regions benefit from a twin strategy. This strategy is composed of (i) building internal capacities such as in-house production depth and absorptive capacity and (ii) sourcing knowledge and expertise at different scales through established as well as newly built network ties. These strategies, implicitly and explicitly, work as mechanisms to bypass some of the structural shortcomings of peripheral regions. These mechanisms emerge as directive principles, although their coupling and balancing varies between and is contingent upon individual cases and the characteristics of projects and firms.

Expanding firm-internal capacities and associated knowledge bases increases the demand of firms for qualified labour and specific human resources. Therefore, in the long run this particular strategy might result in rising pressures to find adequate personnel. Especially when considering the challenging demographic developments (ageing, continued out-migration, etc.) many peripheral regions currently are and will be confronted with in the future. A substantial number of firms as well as regional development actors interviewed as part of the wider research indicate pressures arising from tensed local labour markets-and the issue of recruiting qualified staff is likely to gain even more relevance in the future. To satisfy demand, it will be most important for firms to build attractiveness and visibility-regarding both soft aspects such as employability as well as hard (e.g. monetary) incentives. Building longterm visibility and attractiveness within and beyond regions requires coordinated strategies involving private actors, intermediaries such as economic promotion agencies, business chambers and associations as well as educational institutions. Facilitating such coordination processes 
needs to be a priority of and should be further encouraged by regional decision takers and policymakers.

This research echoes previous studies (e.g. North and Smallbone 2006; Townsend et al. 2016) which emphasise the importance of access to high-quality information and telecommunication technologies (ICTs) for businesses located in peripheral regions. Increasingly digitalised economies rely on powerful ICT infrastructure for networking and marketing, standard working routines and upcoming shifts related to automation and data exchange (e.g. industry 4.0). Thus, if adopted, the provision of high-performance (digital) infrastructures can effectively support businesses from peripheral regions to access wider resources, enlarge networks, expand their reach and ultimately to mitigate isolation and distance (Townsend et al. 2016). Yet, peripheral regions are frequently excluded from access to high-capacity ICTs and 'discriminated against by investments in the telecommunication infrastructure because of the relatively low and dispersed nature of demand' (North and Smallbone 2006, 52), fuelling the digital divide in technology landscapes (Townsend et al. 2016). Many firms consulted in this research use tools such as online procurement and marketing, social media and sophisticated virtual communication/co-development practices as part of their daily business and strategic innovation routines. However, firms from the Erzgebirgskreis in Germany, in particular, perceive the state of their ICT landscape as a distinct 'anachronism' and an inhibiting factor for competitiveness and business development. Thus, in the context of ongoing peripheralisation processes, this chapter argues that the provision of spatially inclusive access to high-performance ICT must be considered a major component of (national) infrastructural as well as regional development policy.

Finally, Faulconbridge's (2017) reflection on relational policy approaches offers valuable links in light of the previously presented findings. This study corroborates the role of actor mobility and the multiscalar organisation of networks in the innovation activities of firms from peripheral regions. It can therefore be suggested that regional development and innovation policy should strive for measures that promote both local/regional as well as (inter)national connectionsrather than pursuing local innovation and the promotion of localised 
networks as guiding imperatives of relational policy. Policy initiatives that take into account the mobility of innovators and encourage firms from peripheral regions to participate in (in)formal networks, trade fairs and industry conventions etc., can effectively support the formation of multi-scalar relations, allowing firms to exchange/acquire innovation-relevant expertise from a broad and dispersed range of actors. Instruments that support for instance trade fair participation, currently maintained by funding agencies in both Saxony and Estonia, could be further strengthened, but need, at the same time, better promotion to become more widely recognised amongst potential beneficiaries: firms from peripheral regions.

Acknowledgements Thanks are due to Alexandre Dubois and Lukas Vonnahme for their feedback on earlier versions of this chapter, which also benefited from discussions during the 'Young Economic Geographers Network (YEGN)’ Workshop 2017 in Goslar.

\section{Notes}

1. In this study, South Estonia is referred to as the area consisting of the counties Pólvamaa, Vơrumaa, Valgamaa and Viljandimaa.

2. This account is grounded on one interview with MÜHLE's co-owner, mainly responsible for product development. Quotes were translated from German. For validation purposes, this section was cross-checked by the interviewee.

3. Read clockwise starting at 12:00 hours, the network maps in Figs. 2 and 3 capture the order in which the networks evolved.

4. This account is grounded on a joint interview with the company's CEO and its chief technologist.

5. MSM (mechanically separated meat) is a method by which leftover meat scraps are harvested using mechanical tools to remove remaining pieces of meat from animal carcasses. MSM does not count towards the meat content of final products.

6. OSKAR markets these products using a 'green label', which is prominently positioned in green on the product's packaging. The label says 'E-vaba' (translated as 'E-free'), indicating the product is free of such substances 
as artificial colouring agents, preservatives, emulsifiers, stabilisers, flavour enhancers, etc. which, if used, must be indicated as 'E-codes' on conventional products. 'Green label' is a marketing tool by OSKAR and does not have official recognition by Estonian regulative bodies.

\section{Recommendations for Further Readings}

Bathelt, Harald, and Johannes Glückler. 2011. The Relational Economy: Geographies of Knowing and Learning, 1st ed. Oxford: Oxford University Press.

Butzin, Anna, Dieter Rehfeld, and Brigitta Widmaier. 2012. Innovationsbiographien: Räumliche und Sektorale Dynamik, vol. 1. Baden-Baden: Nomos.

Ibert, Oliver, Felix C. Müller, and Axel Stein. 2014. Produktive Differenzen. Eine Dynamische Netzwerkanalyse von Innovationsprozessen. Bielefeld: Transcript.

Shearmur, Richard. Christophe Carrincazeaux, and David Doloreux, eds. 2016. Handbook on the Geographies of Innovation. Cheltenham: Edward Elgar.

Yin, Robert K. 2014. Case Study Research: Design and Methods, 5th ed. London: Sage.

\section{References}

Baregheh, Anahita, Jennifer Rowley, and Sally Sambrook. 2009. “Towards a Multidisciplinary Definition of Innovation.” Management Decision 47 (8): 1323-39. https://doi.org/10.1108/00251740910984578.

Butzin, Anna, and Brigitta Widmaier. 2016. "Exploring Territorial Knowledge Dynamics Through Innovation Biographies.” Regional Studies 50 (2): 220_ 32. https://doi.org/10.1080/00343404.2014.1001353.

Cohen, Wesley M., and Daniel A. Levinthal. 1990. "Absorptive Capacity: A New Perspective on Learning and Innovation." Administrative Science Quarterly 35 (1): 128-52. https://doi.org/10.2307/2393553.

Copus, Andrew, and Dimitris Skuras. 2006. "Business Networks and Innovation in Selected Lagging Areas of the European Union: A Spatial 
Perspective." European Planning Studies 14 (1): 79-93. https://doi. org/10.1080/09654310500339885.

Dubois, Alexandre. 2013. "Managing Distance: Small Firm Networks at the Geographic Margins.” PhD diss., Stockholm University.

Edquist, Charles. 2006. "Systems of Innovation: Perspectives and Challenges." In The Oxford Handbook of Innovation, edited by Jan Fagerberg, David C. Mowery, and Richard R. Nelson, 181-208. Oxford: Oxford University Press.

Eisenhardt, Kathleen M. 1989. "Building Theories from Case Study Research.” The Academy of Management Review 14 (4): 532-50. https://doi. org/10.2307/258557.

Fagerberg, Jan. 2006. "Innovation: A Guide to the Literature." In The Oxford Handbook of Innovation, edited by Jan Fagerberg, David C. Mowery, and Richard R. Nelson, 1-26. Oxford: Oxford University Press.

Faulconbridge, James R. 2017. "Relational Geographies of Knowledge and Innovation." In The Elgar Companion to Innovation and Knowledge Creation, edited by Harald Bathelt, Patrick Cohendet, Sebastian Henn, and Laurent Simon, 671-84. Cheltenham: Edward Elgar.

Fitjar, Rune Dahl, and Andrés Rodríguez-Pose. 2016. "Nothing Is in the Air." Growth and Change 48 (1): 22-39. https://doi.org/10.1111/grow.12161.

Flåten, Bjørn-Tore, Arne Isaksen, and James Karlsen. 2015. "Competitive Firms in Thin Regions in Norway: The Importance of Workplace Learning." Norsk Geografisk Tidsskrift 69 (2): 102-11. https://doi.org/10.10 80/00291951.2015.1016875.

Florida, Richard, Patrick Adler, and Charlotta Mellander. 2017. "The City as Innovation Machine." Regional Studies 51 (1): 86-96. https://doi.org/10.10 80/00343404.2016.1255324.

Foss, Nicolai J. 1997. Resources, Firms and Strategies: A Reader in the ResourceBased Perspective. Oxford: Oxford University Press.

Gertler, Meric S. 2003. "Tacit Knowledge and the Economic Geography of Context, or the Undefinable Tacitness of Being (There)." Journal of Economic Geography 3 (1): 75-99. https://doi.org/10.1093/jeg/3.1.75.

Gilly, Jean-Pierre, and André Torre. 2000. "Proximity Relations: Elements for an Analytical Framework." In Industrial Networks and Proximity, edited by Milford B. Green and Rod B. McNaughton, 1-16. Aldershot: Ashgate.

Grillitsch, Markus, and Magnus Nilsson. 2015. "Innovation in Peripheral Regions: Do Collaborations Compensate for a Lack of Local Knowledge 
Spillovers?" The Annals of Regional Science 54 (1): 299-321. https://doi. org/10.1007/s00168-014-0655-8.

Hansen, Teis, and Lars Winther. 2011. "Innovation, Regional Development and Relations Between High- and Low-Tech Industries." European Urban and Regional Studies 18 (3): 321-39. https://doi.org/10.1177/0969776411403990. Hirsch-Kreinsen, Hartmut. 2008. "Low-Technology': A Forgotten Sector in Innovation Policy." Journal of Technology Management \& Innovation 3 (3): 11-20. https://doi.org/10.4067/S0718-27242008000100002.

Ibert, Oliver. 2007. "Towards a Geography of Knowledge Creation: The Ambivalences Between 'Knowledge as an Object' and 'Knowing in Practice.." Regional Studies 41 (1): 103-14. https://doi.org/10.1080/00343400601120346. Jakobsen, Stig-Erik, and Torbjørn Lorentzen. 2015. "Between Bonding and Bridging: Regional Differences in Innovative Collaboration in Norway." Norsk Geografisk Tidsskrift - Norwegian Journal of Geography 69 (2): 80-89. https://doi.org/10.1080/00291951.2015.1016550.

Johansson, Börje, and John M. Quigley. 2003. "Agglomeration and Networks in Spatial Economies." Papers in Regional Science 83 (1): 165-76. https:// doi.org/10.1007/s10110-003-0181-z.

Kühn, Manfred, Matthias Bernt, and Laura Colini. 2016. "Power, Politics and Peripheralization: Two Eastern German Cities." European Urban and Regional Studies 24 (3): 258-73. https://doi.org/10.1177/0969776416637207.

Lundvall, Bengt-äke, and Björn Johnson. 1994. "The Learning Economy." Journal of Industry Studies 1 (2): 23-42. https://doi.org/10.1080/ 13662719400000002.

Malecki, Edward J., and Deborah M. Tootle. 1996. "The Role of Networks in Small Firm Competitiveness." International Journal of Technology Management 11 (1): 43-57.

Maskell, Peter. 2014. "Accessing Remote Knowledge-The Roles of Trade Fairs, Pipelines, Crowdsourcing and Listening Posts." Journal of Economic Geography 14 (5): 883-902. https://doi.org/10.1093/jeg/lbu002.

Moulaert, Frank, and Farid Sekia. 2003. "Territorial Innovation Models: A Critical Survey.” Regional Studies 37 (3): 289-302. https://doi.org/10.1080/ 0034340032000065442.

Nonaka, Ikujiro. 1994. "A Dynamic Theory of Organizational Knowledge Creation.” Organization Science 5 (1): 14-37. https://doi.org/10.1287/orsc.5.1.14.

North, David, and David Smallbone. 2006. "Developing Entrepreneurship and Enterprise in Europe's Peripheral Rural Areas: Some Issues Facing 
Policy-Makers." European Planning Studies 14 (1): 41-60. https://doi. org/10.1080/09654310500339125.

Ozman, M. 2009. "Inter-Firm Networks and Innovation: A Survey of Literature." Economics of Innovation and New Technology 18 (1): 39-67. https://doi.org/10.1080/10438590701660095.

Rammert, Werner. 1997. "Innovation im Netz: Neue Zeiten für technische Innovationen: heterogen verteilt und interaktiv vernetzt." Soziale Welt 48 (4): 397-415.

Rodríguez-Pose, Andrés, and Rune Dahl Fitjar. 2013. "Buzz, Archipelago Economies and the Future of Intermediate and Peripheral Areas in a Spiky World." European Planning Studies 21 (3): 355-72. https://doi.org/10.1080 /09654313.2012.716246.

Shearmur, Richard. 2012. "Are Cities the Font of Innovation? A Critical Review of the Literature on Cities and Innovation." Cities 29 (2): 9-18. https://doi.org/10.1016/j.cities.2012.06.008.

Shearmur, Richard, and David Doloreux. 2016. "How Open Innovation Processes Vary Between Urban and Remote Environments: Slow Innovators, Market-Sourced Information and Frequency of Interaction.” Entrepreneurship \& Regional Development 28 (5-6): 337-57. https://doi.org/ 10.1080/08985626.2016.1154984.

Taylor, Michael, and Bjørn Asheim. 2001. "The Concept of the Firm in Economic Geography.” Economic Geography 77 (4): 315-28. https://doi. org/10.1111/j.1944-8287.2001.tb00167.x.

Ter Wal, Anne L. J., and Ron A. Boschma. 2009. "Applying Social Network Analysis in Economic Geography: Framing Some Key Analytic Issues." The Annals of Regional Science 43 (3): 739-56. https://doi.org/10.1007/ s00168-008-0258-3.

Tödtling, Franz, and Michaela Trippl. 2005. "One Size Fits All?: Towards a Differentiated Regional Innovation Policy Approach.” Research Policy 34 (8): 1203-19, Special Issue: Regionalization of Innovation Policy. https://doi. org/10.1016/j.respol.2005.01.018.

Torre, André. 2008. "On the Role Played by Temporary Geographical Proximity in Knowledge Transmission.” Regional Studies 42 (6): 869-89. https://doi.org/10.1080/00343400801922814.

Townsend, Leanne, Claire Wallace, Alison Smart, and Timothy Norman. 2016. "Building Virtual Bridges: How Rural Micro-Enterprises Develop Social Capital in Online and Face-to-Face Settings." Sociologia Ruralis 56 (1): 29-47. https://doi.org/10.1111/soru.12068. 
van der Panne, Gerben. 2004. "Agglomeration Externalities: Marshall Versus Jacobs." Journal of Evolutionary Economics 14 (5): 593-604. https://doi. org/10.1007/s00191-004-0232-x.

Welz, Gisela. 2003. "The Cultural Swirl: Anthropological Perspectives on Innovation.” Global Networks 3 (3): 255-70. https://doi.org/10.1111/ 1471-0374.00061.

Yin, Robert K. 2014. Case Study Research: Design and Methods, 5th ed. London: Sage.

Open Access This chapter is licensed under the terms of the Creative Commons Attribution 4.0 International License (http://creativecommons. org/licenses/by/4.0/), which permits use, sharing, adaptation, distribution and reproduction in any medium or format, as long as you give appropriate credit to the original author(s) and the source, provide a link to the Creative Commons license and indicate if changes were made.

The images or other third party material in this chapter are included in the chapter's Creative Commons license, unless indicated otherwise in a credit line to the material. If material is not included in the chapter's Creative Commons license and your intended use is not permitted by statutory regulation or exceeds the permitted use, you will need to obtain permission directly from the copyright holder.

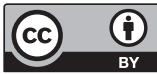




\section{3}

Leading Through Image Making?

On the Limits of Emphasising Agency in Structurally Disadvantaged Rural Places

\section{Bianka Plüschke-Altof and Martiene Grootens}

\section{Introduction}

In recent years, the focus of debates on suitable responses to peripheralisation has increasingly shifted from structural factors of regional polarisation to the practices and room for manoeuvre of the local actors subjected to it (Fischer-Tahir and Naumann 2013; Kay et al. 2012; Nugin and Trell 2015; PoSCoPP 2015; Timár and Velkey 2016). This emphasis on approaches that focus on the agency of local actors has been particularly prominent in the literature on socio-spatial ascriptions (Bürk et al. 2012; Lang 2013; Meyer and Miggelbrink 2013; Paasi 1995; Wacquant et al. 2014) and place leadership practices (Horlings and Marsden 2010; Hidle and Normann 2013; and others) that intensely discuss leading through image making as a potential

B. Plüschke-Altof $(\square)$

Tallinn University, Tallinn, Estonia

M. Grootens

University of Tartu, Tartu, Estonia

(C) The Author(s) 2019

T. Lang and F. Görmar (eds.), Regional and Local Development 
development strategy (for example Paasi 2013; Raagmaa 2002; Semian and Chromý 2014). While the latter certainly plays a crucial role in attempts to overcome territorial stigmatisation-constituting an inherent part of peripheralisation-this chapter questions whether this new focus on agency in the form of active image making also represents a suitable response strategy for rural areas ${ }^{1}$ facing structural disadvantages while simultaneously being encouraged to act as resilient places, proactively fighting those very disadvantages (Bristow 2010; Fischer-Tahir and Naumann 2013; Kay et al. 2012).

This chapter is based on fieldwork conducted in four rural areas of Estonia between 2015 and 2017, as part of the Marie Curie Initial Training Network 'Socio-economic and Political Responses to Regional Polarisation in Central and Eastern Europe' $\left(\mathrm{RegPol}^{2}\right)$. It critically scrutinises the potential agency of place leaders to actively shape structurally disadvantaged areas through image making. Following the ongoing neoliberalisation of regional policy along the lines of competitiveness and economic growth, rural areas are increasingly urged to perform as active 'place-sellers' (Bristow 2010, 160; PoSCoPP 2015; Woods 2013). In the same vein, the local leaders in our four case study areas, which are subject to both material and discursive peripheralisation, also turned to image making and place marketing as ways to overcome these processes and enhance regional development. The case studies included the following municipalities: Järva-Jaani in Central Estonia, the Island of Kihnu in Western Estonia, as well as the newly amalgamated Setomaa ${ }^{2}$ and Tôrva municipalities (northern part of Valga County) in Southern Estonia (for an overview see Map 1). The local decision makers in these areas built on the promises of consumption-oriented place promotion and post-productivist entrepreneurialism that is encouraged by successful best practice examples usually located in structurally advantaged urban areas (Bristow 2005; Shearmur 2012). However, due to the rapid trend of (sub)urbanisation in Central and Eastern Europe in general, and Estonia in particular, rural areas have been increasingly subjected to the processes of material peripheralisation. These have 


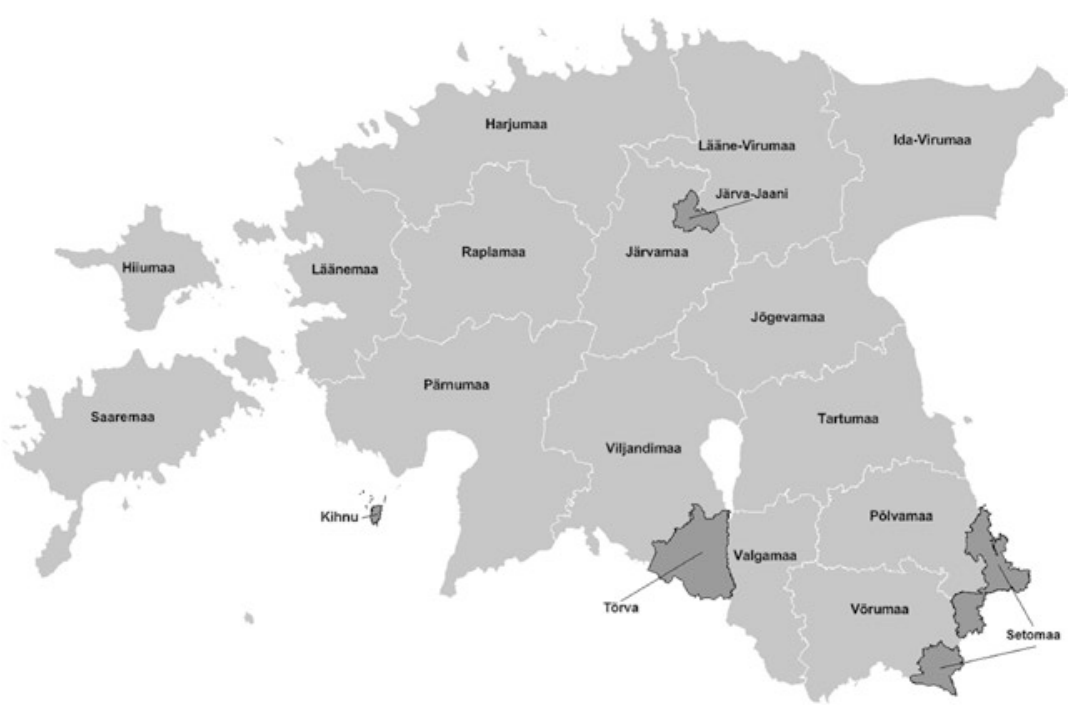

Map 1 Case study areas (Illustration by Grete Kindel)

resulted in tangible structural disadvantages such as socio-economic decline, selective out-migration and institutional thinness (Leetmaa et al. 2013; Nugin and Trell 2015; PoSCoPP 2015). Like other rural areas in post-socialist space (Kay et al. 2012), our case study areas are, moreover, confronted with considerable discursive peripheralisation. Whereas in Setomaa and Kihnu Island this takes the form of a struggle with territorial stigmatisation, Järva-Jaani and Valga County (including Tórva municipality) are dealing with the issue of invisibility. Against this backdrop of great material and discursive peripheralisation, the question arises as to whether this new focus on place leadership and active image making can really fulfil its promises with regards to regional development.

Our case studies convey the limits of such agency-based approaches in structurally disadvantaged rural areas. While leading through image making may function as a possible solution to challenges of regional 
polarisation, these examples show that it may also bring about new problems of idealisation and responsibilisation through urging local leaders to take on ever-growing responsibilities for coping with material and discursive peripheralisation. These challenges faced by rural place leaders do not only result in a shift of responsibilities from the national to the local level due to a heroisation of local agency, but also precipitate neglect of the structurally difficult context in which these response strategies are supposed to take place.

As the chapter will reflect upon, this new focus on agency also has consequences for researchers who wish to make sense of leadership and image making, since they are also agents in those very processes they aim to understand. After introducing the debate on the development potential of leadership through image making, we therefore, move on to discuss the challenges experienced by local leaders who attempt to put these agency-based approaches into practice and the implications they have on the research process. Our analysis builds on 66 interviews conducted with local and regional decision makers and community leaders representing the fields of politics, administration, entrepreneurship, culture, media, tourism and social work (including youth work such as education and sports). These people are well known locally for their engagement with these issues. However, it is beyond the scope of this chapter to analyse all interviews and participant observations (for a detailed analysis, see Grootens 2018; Plüschke-Altof 2018), hence only a selection of these are used in this chapter. They illustrate the challenges facing local actors engaging in leadership through image making, a situation widely found in other rural areas in Estonia, Central and Eastern Europe and beyond. Table 1 gives an overview of the interviewees represented in this chapter. In order to ensure their anonymity, the names have been changed. Moreover, for the same reason, the table only indicates their fields and regions of activity and not the concrete functions they fulfil in the case study areas. Through this analysis, we show the complexity of acting in peripheralised rural places. This also questions the focus on agency-based solutions in contexts of structural disadvantage. 
Table 1 List of interview partners (Illustration by the authors)

\begin{tabular}{llll}
\hline Name & Gender & Field(s) & Region \\
\hline Airi & F & Entrepreneurship, tourism & Kihnu \\
Artur & M & Entrepreneurship, tourism, culture & Järva-Jaani \\
Egert & M & Politics, culture & Valgamaa (Tõrva) \\
Endrik & M & Politics, culture & Kihnu \\
Greeta & F & Journalism, culture & Setomaa \\
Helle & F & Journalism & Valgamaa \\
Jaagup & M & Entrepreneurship, community initiative & Setomaa \\
Imbi & F & Culture & Valgamaa (Tõrva) \\
Katrin & $\mathrm{F}$ & Entrepreneurship, culture, tourism & Kihnu \\
Kulno & $\mathrm{M}$ & Education & Järva-Jaani \\
Liis & $\mathrm{F}$ & Social work & Järva-Jaani \\
Peep & $\mathrm{M}$ & Politics, culture & Valgamaa (Tõrva) \\
Priit & $\mathrm{M}$ & Politics & Kihnu \\
Ragnar & $\mathrm{M}$ & Entrepreneurship, culture & Setomaa \\
Reili & $\mathrm{M}$ & Journalism & Valgamaa \\
Robert & $\mathrm{M}$ & Politics, sports, culture & Järva-Jaani \\
Toomas & $\mathrm{M}$ & Culture, politics & Setomaa \\
\hline
\end{tabular}

\section{The Potential to Act in Times of Peripheralisation: Leading Through Image Making}

Increasing regional polarisation in Central and Eastern Europe and beyond has attracted the attention of researchers trying to make sense of these processes from diverse theoretical standpoints (see Kühn 2015; PoSCoPP 2015 for overview). For some time, this debate has focused on the structural difficulties to which peripheral places are subjected, thereby depicting local actors as passive and receptive (Kay et al. 2012). Recent scholarship has, however, started to analyse these processes with the help of a more relational approach conceptualising peripheralisation as a multi-scalar, multi-level and, above all, contingent process that can only be understood in relation to its counterpart of centralisation (Keim 2006; Kühn 2015; PoSCoPP 2015). By focusing on the (re-)production of uneven spatial developments, this approach urges us to question 
why certain types of spaces, such as the rural areas studied here, are more prone to peripheralisation than others (Keim 2006). While not all rural areas are necessarily peripheral, rurality is often associated with peripherality, mirroring not only existing material difficulties but also the dominant stigmatisation of rural places, especially in Central and Eastern Europe (Fischer-Tahir and Naumann 2013; Kay et al. 2012; Plüschke-Altof 2016). Moreover, as a processual concept, peripheralisation has the potential to include the room for manoeuvre of local actors (Kühn 2015). The re-emphasising of agency in these often structurally defined contexts connects to the ideas of Massey (2004) who, among others, warns against the danger of ignoring agency in places and merely seeing them as victims of distant global processes (re-)produced somewhere else in space. Following the recent popularity of agency-based approaches, these are instead considered as room of negotiation or power struggles, and potential sites of agency by influencing local-global relations (Massey 2004; Woods 2007; Kay et al. 2012).

One way of conceptualising this room for manoeuvre in a regional development context is prevalent in the concept of place leadership. This concept departs from a focus on studying static heroised individuals seen as leaders. Instead, it centres more on leadership as 'a multi-actor process of place-making' (Mabey and Freeman 2010, 509). Leadership, in this reading, is not necessarily seen as an individual activity but as a multi-faceted process of formal and informal actors operating within and beyond place boundaries in an attempt to improve economic_and potentially other-outcomes (Beer and Clower 2013; Sotarauta et al. 2012). Going beyond studying formal leadership only, practised by mayors or governors, place leadership in this sense can also entail the actions of non-elected leaders, such as cultural activists or entrepreneurs, among others. In other words, the concept of leadership widens our understanding of place leaders, which can therefore, include all those actors purposively working towards improving their places. Despite the critique of the concept that it suffers from 'conceptual confusion and endemic vagueness' (Alvesson and Spicer 2012, 369) and its rather functionalistic and normative tendency towards measurable outcomes (Mabey and Freeman 2010), place 
leadership thus has the potential to highlight the role of agency in the development of places. Rodríguez-Pose (2013) even goes so far as to consider leadership the missing factor in explaining why some regions grow and others do not.

It is not only in the literature that leadership is usually seen as positive in itself and openly appreciated, but in our fieldwork this was also visible, as one of our field notes from a visit to Kihnu Island by the Minister for Rural Life illustrates. For him, 'local leadership of regional development is extremely important; it's the only counterweight to the central authority.' He highlights the role of leadership in institutionally thin regions subjected to the consequences of centralisation, which is also echoed in the academic literature (Beer and Clower 2013). In policy discourse, as Estonia's plans for using EU Structural Funds between 2014 and 2020 show, a belief in the importance of human agency can also be witnessed. Framed under the umbrella of enhancing administrative capacity, training events are organised for public sector officials and actors working with NGOs and social partners (Ministry of Finance of the Republic of Estonia 2014). In our interviews, leadership was often understood as positive engagement with communities and connected to activeness in these communities. As Kulno from Järva-Jaani mentioned, 'I really participate in every event, because first of all I am [working at the school]. It is my example for the students [to show] how everything should be done.' This open appreciation of leadership and activeness for the communities in the areas studied makes it clear that these concepts are not only theoretically recognised as essential, but also practically appreciated by actors living in these regions.

Alongside place leadership, also the importance of socio-spatial discourses has been acknowledged in the research on regional polarisation and peripheralisation. Since the cultural turn in human geography, a growing body of literature has focused on the discursive dimension of regional polarisation. On the one hand, it largely concentrates on the meaning that communicative processes have for the evolution and persistence of peripheralisation processes (Bürk et al. 2012; Lang 2013; Meyer and Miggelbrink 2013; Paasi 1995; Wacquant et al. 2014), especially in rural areas (Kay et al. 2012). On the other, it treats regional images as ways of dealing with peripheralisation, or as so-called 
soft development factors. These can be employed as external marketing tools or as an endogenous resource to strengthen social capital in a region (Paasi 2013; Semian and Chromý 2014). Despite acknowledging the power of images that tend to stick to places by influencing individual as well as collective actions (Bürk et al. 2012; Wacquant et al. 2014), the literature also highlights the agency of people and places to negotiate the images they are subjected to (Meyer and Miggelbrink 2013; Valentine 2007).

In the research on place marketing and place making in particular, there is a strong focus on 'proactive localities' (Leetmaa et al. 2013, 17) that has also inspired the debates in our Estonian case studies and consequently trickled down into numerous national and local development plans (Agan and Kask 2009; Raagmaa 2002). The local leadership in these areas became aware of the crucial role that images might play for their place development in two different ways. While Kihnu Island and Setomaa previously struggled with processes of territorial stigmatisation ranging from a feeling of neglect to the tangible loss of potential investors in the region, Järva-Jaani and Valga instead encountered the problem of invisibility or of being 'blank spaces on the map'. The conclusions that they drew from these differing experiences were, however, very similar. The cultural activist Toomas from Setomaa and teacher Kulno from Järva-Jaani noted that they 'seriously reconsidered things and then decided that the orientation had to be changed' (Toomas) and from that point 'do whatever it [takes] to be in the big picture, to be in the big plan' (Kulno). Hence, they opted for the response strategy of active image making, which Bürk et al. $(2012$, 339) describe as 'trying to prove the opposite.' It means that local actors acknowledge the negative images ascribed to their region and turn them on their head to create positive ones. This kind of image reversal is one of the most common response strategies to 'discursive act[s] of peripheralization' (Bürk 2013, 169). It stands in contrast to the other most common responses: that of reproducing negative ascriptions, which might lead to a feeling of hopelessness among the locals, and that of an absolute rejection of the ascribed socio-spatial images (Bürk et al. 2012). 


\section{Unexpected Challenges? Responsibilisation and Idealisation}

Leadership and image making have thus been discussed as agency-based approaches with the potential for a better understanding of peripheralisation processes and dealing with them. However, while offering an alternative to a structurally determined conceptualisation of place development, this new focus on agency also poses unexpected challenges for local actors in structurally disadvantaged rural areas who try to put these response strategies into practice.

A central challenge local actors experience when trying to react to the backdrop of a new regional policy focus on leadership and agency is the accompanying shift of responsibilities from the national to the local level. In our case studies, it became clear how local actors are urged to take over ever more responsibilities from the state under the veil of active citizenship. For example, during one fieldwork visit, the local entrepreneur Jaagup was confronted with this kind of responsibilisation by national politicians paying a visit to the Setomaa region. After he had extensively reported to them on the enormous efforts undertaken by local activists to overcome regional peripheralisation, the politicians replied with an appraisal of local activism while simultaneously suggesting there should be an increase in the number of such active people in order to boost regional development. Jaagup then replied by emphasising that his time is, in fact, limited and that his 'wife might also like to see him once in a while.' Hence, while the politicians drew on a discourse that shifts the responsibility for regional development away from the state to the regions themselves, Jaagup pointed out the consequences this focus on place leadership have for the personal lives of the people who take over these responsibilities. The problem of local activists 'terribly overburdening themselves,' as Setomaa journalist and cultural activist Greeta phrased it, has been an issue in all of our four case studies. In a broader sense, the case studies thus point to the neoliberal promotion of rural leadership as, in fact, propagating a 'broader "selfhelp" ethos' that urges local actors to take on state responsibilities while 
simultaneously downplaying the individual burdens that come with it (Kroehn et al. 2010, 498).

The neoliberal appraisal of leaders taking on responsibilities (and simultaneous denial of the price they pay for it) has a further downside: the blaming of people who are either unable or unwilling to take on these responsibilities. In our case studies, this blaming often took the form of a division between the active and the non-active. For example, Greeta and Toomas, two cultural activists from Setomaa, criticise the non-active as not being willing 'to take on any kind of responsibility.' Liis, a social worker from Järva-Jaani, criticises unemployed people, saying that, 'they are the kind of people that don't want to go and work.' Priit, one of Kihnu's political leaders, went so far as to make the following request from the interviewer: 'if you have any active people who want to live on a small island, then send them here.'

In line with the research on territorial stigmatisation (Bürk et al. 2012; Wacquant et al. 2014), this simultaneous appreciation of activeness and a lack of understanding for the non-active usually goes handin-hand with a depiction of the social pathologies of the latter who are portrayed variously as development-resistant alcoholics, social welfare abusers or Soviet nostalgics with personal initiative levels 'close to zero' (Toomas). Imbi, a cultural activist from Valga region, puts it this way:

Work? Oh yeah, there are so many out there who are searching for employees. This is what they say. There used to be a lack of employment, now there is a lack of employees. Because the state benefits those lazy people who are sitting dust to dawn in the park with their bottles of beer. Gives them money, and they don't go to work. (Interview, Valgamaa, 23 November 2016)

The strong focus on leadership and active coping, therefore, does not only lead to the placing of responsibilities onto local actors, but also to the disqualification of those who are unable or unwilling to meet these normative standards. Thus, there is an interesting ambiguity here that mirrors how local actors are also deeply embedded in neoliberalised (regional) development discourses. On the one hand, they take a critical stance towards local responsibilisation by emphasising the price 
they pay for taking on responsibility for regional development. On the other, they reproduce these discourses by setting themselves as positive role models of leadership and activeness and blaming and responsibilising exactly those among the local population who cannot partake in the new development and cannot live up to these roles.

Apart from the issue of responsibilisation, which highlights the usefulness of some actors and the ascribed uselessness of others, we also encountered practices of idealisation. The attempts to overcome territorial stigmatisation with active image making often result in a purely positive portrayal of the place through which structural disadvantages fade into the background. Ragnar from Setomaa and Airi from Kihnuboth active in the field of entrepreneurship—also acknowledged that, due to image campaigns, 'from outside we look better than we actually are' (Ragnar) and 'if we want them to see how poor we are [...], then it is possible,' but 'no one wants to do that' (Airi). Further, when talking to entrepreneur Artur and politician Robert, from Järva-Jaani, this idealisation became evident. At the start of the interview, they were not keen to discuss the problems in their region at all, as Artur explained: 'there is no point in just whining, it will not take you anywhere.' This tendency among dominant local groups to idealise their place towards the outside and thereby omit persistent material difficulties has also been problematised within the research on rural idylls (Little and Austin 1996; Matthews et al. 2000; Valentine 1997; Watkins and Jacoby 2007). Not stating these difficulties might thus also mean not dealing with them in practice, which is a considerable risk considering ongoing peripheralisation in these areas.

Moreover, those who wish to address persistent problems might be faced with a situation in which they are treated as 'traitors' or 'trouble-makers' who destroy the beautiful image of a place that others have worked so hard for. Journalists in the Valga region experienced this when they decided to openly problematise and illustrate the consequences of its ongoing decline in population. For example, one of the journalists, whom we here call Helle, explained how the difference between what still appeared in her memories of the place where she spent her early childhood and 'what is there now' motivated her to deal with the topic in a set of newspaper articles, including a photo series. 
This initiative was supported by a local leader who gave an open interview about the problems he encountered. While the articles initiated an intense debate on the peripheralisation of the region, they also resulted in the same leader being accused of having 'ruined our image.' Further, there were complaints against Reili, the newspaper editor, as to why they would only depict 'ugly houses when we have nice ones here too.' As a consequence, the editor decided to publish a counterbalancing photo series portraying only sites of beauty within the region.

What is evident from these examples is that the local leadership aims to put into practice what has been suggested to them in recent regional policy debates, namely, to be active leaders and place sellers. However, against the backdrop of rural peripheralisation processes, they also quickly experience the limits that such agency-based response strategies have in structurally disadvantaged places. While certainly offering novel possibilities for local development, leading through image making therefore, also poses new challenges of responsibilisation and idealisation in structurally disadvantaged rural places. How then to address persistent material difficulties and the limits of local agency when openly stating them is seen as development resistance or re-stigmatisation of the region?

\section{$4 \quad$ Researching Leadership and Image Making: Reflections on the Agency of the Researcher}

When trying to make sense of these practices of place leadership and image making, we as researchers also faced the challenges of acting in structurally disadvantaged places. Since our research took place in regions facing material difficulties, we noticed that we were seen as potential solution bringers and allies of our interviewees, as this occurrence during one of our field visits to Kihnu shows:

After saying thanks for the interview and goodbye, the interviewee Katrin (who is active in the fields of entrepreneurship, culture and tourism) once 
again re-emphasised the difficulties that they were facing in the community, dealing with unemployment and lack of future economic prospects. She finished the conversation by expressing her hope that the research she was now participating in could also have a positive influence on finding some new ideas for development. (Field notes, Kihnu, 21 January 2016)

On another field visit, after finishing the 'official' part of the interview, Egert, a local politician from the Valga region continued to discuss the future perspectives of the place: 'But if you [the interviewer] would come here and work on improving the region, then...' He left the sentence unfinished. For the farewell he prompted, 'Why don't you move here? What are you doing in [the city] anyway!' These examples show how hope is vested in the researchers to provide some sort of solution for these places, which also includes the expectation to engage in local image reversal campaigns. This is further demonstrated by the following field note from a meeting of a local development group in Valga County:

At the end of a lengthy meeting, which saw lively discussions on the pros and cons of engaging in place marketing projects with the help of development funds, Peep (a former interviewee and local politician) approached me with a request: 'Listen, how occupied will you be with your work in the near future? I was wondering if you might care to write something for our local newspaper? I mean, your research clearly shows that it is not a question of wanting to deal with image making but that we must, that we must develop the region into a brand.' (Field notes, Valgamaa, 30 November 2016)

This local re-interpretation of our research aims and results initially left us puzzled. Did we really convey this image when introducing ourselves and our research? After repeated occurrences of such incidents, it became clear that these were attempts to make our research part of local development and image making processes; our research itself was seen as instrumental in the processes we were studying. For us, this resulted in real conflicts of loyalty: how could we ever address findings that could be deemed critical or not relevant by Peep, Katrin, Egert and 
others after they had provided us with access to the field and vested so much hope in us? How should we position ourselves towards these local expectations that we get involved?

This not only made us very conscious of the question of how to frame or present our research results (cf. Hörschelmann and Stenning 2008), but also of the fact that as researchers we cannot exempt ourselves from local processes of which we inevitably become part. This also requires carefully reflecting upon our own agency as well as the ways in which we change the places through our mere presence in them (Annist and Kaaristo 2013; Blondel, forthcoming). We are aware that researchers vary in their willingness to engage with the social processes they study. Their roles can differ from that of a 'neutral' bystander where any interference with social groups leads to 'systemic bias' (Hammersley $2006,11)$ and is thus to be discouraged, to a more activist position that views contributing to social change and empowerment of marginalised groups as a duty of social research (Kitchin 1999). While it, therefore, depends on the positionality of the researcher whether these practices are interpreted as legitimate requests by certain actors to play a more active part in the research or as attempts to instrumentalise it for their own purposes, they certainly influence the researcher's position in the field and the knowledge produced.

Next to our embedded roles as researchers in the field, the methodological choices we make also influence knowledge production in its final form. As Miggelbrink and Meyer (2015) have strikingly noted, the only way not to reify spatial images is by refusing to use them at all, rendering research on these topics and writing about them impossible. Therefore, the risk of reproducing hegemonic images of placestigmatising or idealising - in the way we put questions to our interviewees or present our results is real and often remains unreflected upon. Moreover, due to the difficulty in grasping local power structures when entering the field as an outsider, there is also the risk of involuntarily reproducing them in the form of bias in interview partner selection or data collection (Annist 2013; Hörschelmann and Stenning 2008). These biases influence the stories we are told and hence also those we retell afterwards. This holds especially true in a post-socialist 
context, where social networks are often quite fractured and key actors, therefore, difficult to find (Hörschelmann and Stenning 2008). We experienced this quite acutely when talking to Endrik, long involved in the political and cultural development of Kihnu Island:

Listen, Mart only gives you the names of his election union and they say the same to you. [...] They belong to the same wing which is now in power. But if you want to listen a little bit to the opposite side as well, I suggest you speak to Kadri. (Interview, Kihnu, 22 February 2016)

Most such fieldwork experiences occurred after the 'official' parts of the interviews were over. Instead of exempting these ambiguous situations and the ambivalent feeling they cause from the research results, we suggest regarding them as rare opportunities to reflect analytically upon the intentions and hopes of the interviewee, who may provide the researcher with certain images of the region or recommendations for other interviewees for a specific reason. Considering the contextuality of socio-spatial discourses (Valentine 2007), it is thus key to ask ourselves continuously how we have influenced the field through our presence, if we have spoken to all relevant groups, and what kind of stories the interviewees would convey to other people or in a different setting.

\section{$5 \quad$ The Limits of Agency in Structurally Disadvantaged Places: Conclusions}

Agency-based concepts such as leadership or image making have been at the heart of recent debates on responses to regional polarisation and also have an important place in this book: Regional and Local Development in Times of Polarisation: Rethinking Spatial Policies in Europe. While acknowledging the potential in these concepts, in this chapter, we have first of all shed light on the limits experienced by local practitioners in structurally disadvantaged areas who try to employ leading through image making as a potential solution for 
the peripheralisation of their regions. After acknowledging the room for manoeuvre that these agency-based approaches might open up according to the literature and our fieldwork, we pointed out the potential challenges they pose. On the one hand, we have problematised the process of responsibilisation of local actors, in which local leaders are praised for their activeness (while downplaying the risk of being overburdened by taking over these responsibilities) and simultaneously those actors who are neither willing nor able to take up these responsibilities are blamed for their 'inactiveness.' This responsibilisation of local actors goes hand-in-hand with the danger of neglecting the structurally disadvantaged contexts in which they find themselves. On the other hand, whereas leadership and active image making are often discussed as strategies to overcome stigmatisation discourses, and therefore peripheralisation processes, we have demonstrated that they also pose the risk of idealising these places. In this way, image making - as an example of leading peripheral places-very clearly shows how the active showcasing of some positive or clearly defined images inevitably hides other negative or more ambiguous images. It is important to also bring the latter to the fore so as to make the challenges of acting under the circumstances of peripheralisation visible and therefore debatable.

Secondly, this chapter has reflected on the agency of the researcher trying to make sense of these response strategies. As researchers, with our writing, case and interviewee selection or even our mere presence, we are not exempt but in fact deeply embedded in the field we study, and therefore in the local image making and development processes. Our research practices themselves might even contribute to the processes of responsibilisation, idealisation or stigmatisation we have described, since we are also active agents in the processes we study. Failing to acknowledge this agency of researchers misses out on gaining a more reflective understanding of the processes we aim to comprehend.

Thus, in order to gain deeper insight into the ways in which peripheral places are produced, we propose a more processual understanding of place development in general and of the 'hidden diversities' (Kay et al. 2012, 55) within peripheral rural places in particular. 
Places can thereby be conceptualised in a heterogeneous way, which acknowledges the multiple modes of (non-) engagement, images and relations constituting them. This also results in a rather nuanced approach towards agency where rural areas as a whole can be seen as 'inconsistent and becoming' (Kay et al. 2012, 60, emphasis added). Such a structurally contextualised understanding of agency can only come to the fore by going beyond the orthodox methods of standard interview situations. Ethnographic methods, as Hörschelmann and Stenning (2008) propose, are useful in this regard as they are better able to grasp local power relations. Only due to longer term or repeated visits to the field were we able to understand such power structures and see beyond the visible leaders and positive images. We thus believe that such ambivalent fieldwork situations as we have described above should in particular be reflected upon in analyses instead of omitting them as disturbing background noise. We argue that only by using these 'slower' methods is it possible to overcome situations in which only the same spokespersons for development, who convey the ever-same images, are interviewed and listened to. More concretely, this means that when researchers are selecting cases they should also keep an eye open for those not-so-perfect leaders and 'less glossy' images in order to not simply showcase yet another best practice example of actively coping places.

By paraphrasing Halfacree $(2006,49)$, we therefore argue that 'only through a focus on contextual practice,' which re-considers the structural limits of agency, can we as practitioners and researchers try to come closer to understanding the 'truth' of place making in rural space, which also applies to situations in which structural factors are preventing an active response or there are no marketable images to instrumentalise. Only by acknowledging this multiplicity of images, these modes of activeness, and thereby also the complexity of agency in structurally disadvantaged contexts, are we able to gain more realistic insights into the potentials of image- and agency-based responses to regional polarisation. Despite their promise such strategies have to consider both problems of stigmatisation (and invisibility) and problems of idealisation as well as not only the possibilities but also the (structural) limits of acting in peripheral places. 
Acknowledgements We would like to thank Maaja Vadi and the anonymous reviewers for their helpful comments on earlier drafts of this chapter, and Grete Kindel for designing the map.

\section{Notes}

1. Even though we are aware of their conceptual differences, for the purpose of this chapter we use place, region and area interchangeably.

2. For more information on the historical region of Setomaa and its leadership practices, see Annist (2013) and Plüschke-Altof (2018).

3. Interviews were conducted in English or in Estonian and subsequently translated into English.

\section{Literature Recommendations}

Grootens, Martiene. 2018. "Leading Places on the Map: Opening Up Leadership Practices in Two Estonian Peripheral Places." Administrative Culture 18 (2): 203-21.

Hörschelmann, Kathrin, and Alison Stenning. 2008. "Ethnographies of Postsocialist Change." Progress in Human Geography 32 (3): 339-61. https://doi.org/10.1177/0309132508089094.

Mabey, Chris, and Tim Freeman. 2010. "Reflections on Leadership and Place." Policy Studies 31 (4): 505-22. https://doi. org/10.1080/01442871003723465.

Miggelbrink, Judith, and Frank Meyer. 2015. "Lost in Complexity? Researching the Role of Socio-Spatial Ascriptions in the Process of Peripheralization." In Understanding Geographies of Polarization and Peripheralization. Perspectives from Central and Eastern Europe and Beyond, edited by Thilo Lang, Sebastian Henn, Wladimir Sgibnev, and Kornelia Ehrlich, 62-79. New Geographies of Europe. Basingstoke: Palgrave Macmillan.

Plüschke-Altof, Bianka. 2018. "Re-Inventing Setomaa. The Challenges of Fighting Stigmatisation in Peripheral Rural Areas in Estonia." Geographische Zeitschrift 106 (2): 121-45. https://doi.org/10.25162/gz-2018-0010. 


\section{References}

Agan, Andres, and Triin Kask. 2009. "Place Marketing Implementation in Different Administrative Subdivisions: Estonian Case Study." In Eesti Majanduspoliitilised Väitlused XVII, edited by Sulev Mäeltsemees and Janno Reiljan, 19-36. Berlin: Berliner Wissenschafts-Verlag.

Alvesson, Mats, and André Spicer. 2012. "Critical Leadership Studies: The Case for Critical Performativity." Human Relations 65 (3): 367-90. https:// doi.org/10.1177/0018726711430555.

Annist, Aet. 2013. "Heterotopia and Hegemony: Power and Culture in Setomaa." Journal of Baltic Studies 44 (2): 249-69. https://doi.org/10.1080/ 01629778.2013.775853.

Annist, Aet, and Maarja Kaaristo. 2013. "Studying Home Fields: Encounters of Ethnology and Anthropology in Estonia." Journal of Baltic Studies 44 (2): 121-51. https://doi.org/10.1080/01629778.2013.775846.

Beer, Andrew, and Terry Clower. 2013. "Mobilizing Leadership in Cities and Regions." Regional Studies, Regional Science 1 (1): 5-20. https://doi.org/10.1 080/21681376.2013.869428.

Blondel, Cyril. Under Review. "How Can We Approach Peripheralisation Without Peripheralising? Decolonising (Our) Discourses on Socio-Spatial Polarisation in Europe."

Bristow, Gillian. 2005. "Everyone's a 'Winner': Problematising the Discourse of Regional Competitiveness." Journal of Economic Geography 5 (3): 285304. https://doi.org/10.1093/jeg/lbh063.

Bristow, Gillian. 2010. "Resilient Regions: Re-'place'ing Regional Competitiveness." Cambridge Journal of Regions, Economy and Society 3 (1): 153-67. https://doi.org/10.1093/cjres/rsp030.

Bürk, Thomas. 2013. "Voices from the Margin: The Stigmatization Process as an Effect of Socio-Spatial Peripheralization in Small-Town Germany." In Peripheralization: The Making of Spatial Dependencies and Social Injustice, edited by Andrea Fischer-Tahir and Matthias Naumann, 168-86. Wiesbaden: Springer VS.

Bürk, Thomas, Manfred Kühn, and Hanna Sommer. 2012. "Stigmatisation of Cities: The Vulnerability of Local Identities." Raumforschung und Raumordnung 70 (4): 337-47. https://doi.org/10.1007/s13147-012-0160-4. Fischer-Tahir, Andrea, and Matthias Naumann. 2013. "Introduction: Peripheralization as the Social Production of Spatial Dependencies and Injustice." In Peripheralization: The Making of Spatial Dependencies and 
Social Injustice, edited by Andrea Fischer-Tahir and Matthias Naumann, 9-26. Wiesbaden: Springer VS.

Grootens, Martiene. 2018. "Leading Places on the Map: Opening Up Leadership Practices in Two Estonian Peripheral Places." Administrative Culture 18 (2): 203-21.

Halfacree, Keith. 2006. "Rural Space: Constructing a Three-Fold Architecture." In The Handbook of Rural Studies, edited by Paul Cloke, Terry Marsden, and Patrick Mooney, 44-62. London: Sage.

Hammersley, Martyn. 2006. "Ethnography: Problems and Prospects." Ethnography and Education 1 (1): 3-14. https://doi.org/10.1080/17457820500512697.

Hidle, Knut, and Roger Henning Normann. 2013. "Who Can Govern? Comparing Network Governance Leadership in Two Norwegian City Regions." European Planning Studies 21 (2): 115-30. https://doi.org/10.10 80/09654313.2012.722924.

Horlings, Lummina Gertruda, and Terry Keith Marsden. 2010. "Social Capital, Leadership and Policy Arrangements in Generating Sustainable European Rural Regions." BRASS Working Paper Series 58, Cardiff University.

Hörschelmann, Kathrin, and Alison Stenning. 2008. "Ethnographies of Postsocialist Change.” Progress in Human Geography 32 (3): 339-61. https:// doi.org/10.1177/0309132508089094.

Kay, Rebecca, Sergei Shubin, and Tatjana Thelen. 2012. "Rural Realities in the Post-socialist Space." Journal of Rural Studies 28 (2): 55-62. https://doi. org/10.1016/j.jrurstud.2012.03.001.

Keim, Karl-Dieter. 2006. "Peripherisierung ländlicher Räume - Essay." Aus Politik und Zeitgeschichte 37: 3-7. http://www.bpb.de/apuz/29544/ peripherisierung-laendlicher-raeume-essay? $\mathrm{p}=$ all.

Kitchin, Rob. 1999. "Morals and Ethics in Geographical Studies of Disability." In Geography and Ethics: Journeys Through a Moral Terrain, edited by James Proctor and David Smith, 223-36. London: Routledge.

Kroehn, Michael, Alaric Maude, and Andrew Beer. 2010. "Leadership of Place in the Rural Periphery: Lessons from Australia's Agricultural Margins.” Policy Studies 31 (4): 491-504. https://doi.org/10.1080/01442871003723457.

Kühn, Manfred. 2015. "Peripheralization: Theoretical Concepts Explaining Socio-Spatial Inequalities." European Planning Studies 23 (2): 367-78. https://doi.org/10.1080/09654313.2013.862518.

Lang, Thilo. 2013. "Conceptualizing Urban Shrinkage in East Germany: Understanding Regional Peripheralization in the Light of Discursive Forms of Region Building." In Peripheralization: The Making of Spatial 
Dependencies and Social Injustice, edited by Andrea Fischer-Tahir and Matthias Naumann, 224-38. Wiesbaden: Springer VS.

Leetmaa, Kadri, Agnes Kriszan, Mari Nuga, and Joachim Burdack. 2013.

"Strategies to Cope with Shrinkage in the Lower End of the Urban Hierarchy in Estonia and Central Germany." European Planning Studies 23 (1): 147-65. https://doi.org/10.1080/09654313.2013.820100.

Little, Jo, and Patricia Austin. 1996. "Women and the Rural Idyll." Journal of Rural Studies 12 (2): 101-11. https://doi.org/10.1016/0743-0167(96)00004-6. Mabey, Chris, and Tim Freeman. 2010. "Reflections on Leadership and Place." Policy Studies 31 (4): 505-22. https://doi.org/10.1080/01442871003723465. Massey, Doreen. 2004. "Geographies of Responsibility." Geografiska Annaler: Series B, Human Geography 86 (1): 5-18. https://doi.org/10.1111/j.04353684.2004.00150.x.

Matthews, Hugh, Mark Taylor, Kenneth Sherwood, Faith Tucker, and Melanie Limb. 2000. "Growing-Up in the Countryside: Children and the Rural Idyll." Journal of Rural Studies 16 (2): 141-53. https://doi.org/10.1016/ S0743-0167(99)00059-5.

Meyer, Frank, and Judith Miggelbrink. 2013. "The Subject and the Periphery: About Discourses, Loopings and Ascriptions." In Peripheralization: The Making of Spatial Dependencies and Social Injustice, edited by Andrea Fischer-Tahir and Matthias Naumann, 207-23. Wiesbaden: Springer VS.

Miggelbrink, Judith, and Frank Meyer. 2015. "Lost in Complexity? Researching the Role of Socio-Spatial Ascriptions in the Process of Peripheralization." In Understanding Geographies of Polarization and Peripheralization. Perspectives from Central and Eastern Europe and Beyond, edited by Thilo Lang, Sebastian Henn, Wladimir Sgibnev, and Kornelia Ehrlich, 62-79. New Geographies of Europe. Basingstoke: Palgrave Macmillan.

Ministry of Finance of the Republic of Estonia. 2014. "Operational Programme for Cohesion Policy Funds 2014-2020.” 2014EE16M3OP001. Tallinn. http://www.struktuurifondid.ee/sites/default/files/2014-2020.pdf.

Nugin, Raili, and Elen Trell. 2015. "(Re)searching Post-socialist Rural Youth:

Towards a Nuanced Understanding." In 'In Search of... 'New Methodological Approaches to Youth Research, edited by Airi-Alina Allaste and Katrin Tiidenberg, 258-81. Newcastle-upon-Tyne: Cambridge Scholars.

Paasi, Anssi. 1995. "The Social Construction of Peripherality: The Case of Finland and the Finnish-Russian Border Area." In Competitive European Peripheries, edited by Heikki Eskelinen and Folke Snickars, 235-58. Advances in Spatial Science. Berlin: Springer. 
Paasi, Anssi. 2013. "Regional Planning and the Mobilization of 'Regional Identity': From Bounded Spaces to Relational Complexity." Regional Studies 47 (8): 1206-19. https://doi.org/10.1080/00343404.2012.661410.

Plüschke-Altof, Bianka. 2016. "Rural as Periphery Per Se? Unravelling the Discursive Node.” Sociální studia/Social Studies 13 (2): 11-28.

Plüschke-Altof, Bianka. 2018. "Re-Inventing Setomaa. The Challenges of Fighting Stigmatisation in Peripheral Rural Areas in Estonia." Geographische Zeitschrift 106 (2): 121-45. https://doi.org/10.25162/gz-2018-0010.

PoSCoPP Research Group. 2015. "Understanding New Geographies of Central and Eastern Europe." In Understanding Geographies of Polarization and Peripheralization. Perspectives from Central and Eastern Europe and Beyond, edited by Thilo Lang, Sebastian Henn, Wladimir Sgibnev, and Kornelia Ehrlich, 1-21. New Geographies of Europe. Basingstoke: Palgrave Macmillan.

Raagmaa, Garri. 2002. "Regional Identity in Regional Development and Planning." European Planning Studies 10 (1): 55-76. https://doi. org/10.1080/09654310120099263.

Rodríguez-Pose, Andrés. 2013. "Do Institutions Matter for Regional Development?” Regional Studies 47 (7): 1034-47. https://doi.org/10.1080 /00343404.2012.748978.

Semian, Michal, and Pavel Chromý. 2014. "Regional Identity as a Driver or a Barrier in the Process of Regional Development: A Comparison of Selected European Experience." Norsk Geografisk Tidsskrift - Norwegian Journal of Geography 68 (5): 263-70. https://doi.org/10.1080/00291951.2014.961540.

Shearmur, Richard. 2012. "Are Cities the Font of Innovation? A Critical Review of the Literature on Cities and Innovation." Cities 29 (2): 9-18. https://doi.org/10.1016/j.cities.2012.06.008.

Sotarauta, Markku, Lummina Horlings, and Joyce Liddle. 2012. Leadership and Change in Sustainable Regional Development. Abingdon: Routledge.

Timár, Judit, and Gábor Velkey. 2016. "The Relevance of the Political Economic Approach: The Interpretations of the Rural in the Migration Decision of Young Women and Men in an Economically Backward Region." Journal of Rural Studies 43: 311-22. https://doi.org/10.1016/j. jrurstud.2015.11.012.

Valentine, Gill. 1997. "A Safe Place to Grow Up? Parenting, Perceptions of Children's Safety and the Rural Idyll." Journal of Rural Studies 13 (2): 13748. https://doi.org/10.1016/S0743-0167(97)83094-X. 
Valentine, Gill. 2007. "Theorizing and Researching Intersectionality: A Challenge for Feminist Geography." The Professional Geographer 59 (1): 10-21. https://doi.org/10.1111/j.1467-9272.2007.00587.x.

Wacquant, Loïc, Tom Slater, and Virgílio Borges Pereira. 2014. "Territorial Stigmatization in Action." Environment and Planning A: Economy and Space 46 (6): 1270-80. https://doi.org/10.1068/a4606ge.

Watkins, Francine, and Ann Jacoby. 2007. "Is the Rural Idyll Bad for Your Health? Stigma and Exclusion in the English Countryside." Health \& Place 13 (4): 851-64. https://doi.org/10.1016/j.healthplace.2007.02.002.

Woods, Michael. 2007. "Engaging the Global Countryside: Globalization, Hybridity and the Reconstitution of Rural Place." Progress in Human Geography 31 (4): 485-507. https://doi.org/10.1177/0309132507079503.

Woods, Michael. 2013. "Regions Engaging Globalization: A Typology of Regional Responses in Rural Europe." Journal of Rural and Community Development 8 (3): 113-26.

Open Access This chapter is licensed under the terms of the Creative Commons Attribution 4.0 International License (http://creativecommons. org/licenses/by/4.0/), which permits use, sharing, adaptation, distribution and reproduction in any medium or format, as long as you give appropriate credit to the original author(s) and the source, provide a link to the Creative Commons license and indicate if changes were made.

The images or other third party material in this chapter are included in the chapter's Creative Commons license, unless indicated otherwise in a credit line to the material. If material is not included in the chapter's Creative Commons license and your intended use is not permitted by statutory regulation or exceeds the permitted use, you will need to obtain permission directly from the copyright holder.

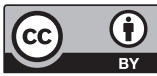




\section{Part IV}

Conclusions: About the Relevance of Scientific Research for Political Practice and Policy Making 


\title{
14
}

\section{Understanding and Going Beyond the Regional Policy Paradox: Conceptual Contributions to Studying Socio-Spatial Polarisation in Europe}

\author{
Garri Raagmaa, Erika Nagy, \\ Franziska Görmar and Thilo Lang
}

The goal of this concluding chapter is to shed light on the conceptual value of the book. We discuss the chapters within the framework of the overall conceptual approach linking territorial cohesion and socio-spatial polarisation with the notion of spatial justice and also connect analytical findings with essential policy recommendations, both of which complement each other. Growing social polarisation and economic inequalities unfolding in new forms across various places brought about academic and policy debates on the meanings of 'development', the ways its dimensions (economic, social, cultural, political) are interrelated, and, moreover, on how macro-structural changes are entangled

\author{
G. Raagmaa $(\bowtie)$ \\ University of Tartu, Tartu, Estonia \\ E. Nagy
}

Centre for Economic and Regional Studies,

Hungarian Academy of Sciences (CERS-HAS),

Békéscsaba, Hungary

(C) The Author(s) 2019

T. Lang and F. Görmar (eds.), Regional and Local Development 
with local and regional processes as well as institutional and social contexts (Pike et al. 2017; Storper 2014). This book contributes to discussing socio-spatial inequalities in relation to macro-structural changes from a critical-spatial perspective of the European 'peripheries'-not only adding a new scalar focus for researching spatial unevenness, but also unveiling how power relations of global/financial capitalism are reproduced through institutional practices across scales (yet played out in many different ways within the periphery) and excavating the reasons for the 'system failures' of actual development policies (see Hudson and Pickles; Hadjimichalis; Pósfai and Jelinek in this volume).

Nowadays, when austerity measures and neoliberal policies are imposed by a few member states and a specific European elite influences development in the whole European Union (see Hudson and Pickles as well as Hadjimichalis in this volume), it is more than timely to ask questions going beyond classical economic development. How can we support regional and local development in a way that helps to decrease socio-spatial polarisation? What kinds of policies are needed to offer equal opportunities for similar living conditions and life chances in all areas and across different categories of space? How do we want to live in future?

As these questions show, we do not understand socio-spatial polarisation as a static and unidirectional concept but as a dynamic one (Kühn and Lang 2017) that can be challenged, rejected or even reversed in the long run (Keim 2006; Lang 2013). The so-called peripheries 'do at times have options, which can become game-changers' (Kühn et al. 2016, 13) and the dynamic, procedural and open character of discourses allows not only central actors but peripheral ones to speak and eventually counteract hegemonic discourses with alternative ones. Some chapters in this book

F. Görmar · T. Lang

Leibniz Institute for Regional Geography, Leipzig, Germany

T. Lang

Global and European Studies Institute, University of Leipzig, Leipzig, Germany 
show that actors can regain control over the development of their regions if they are supported by a political framework that does not restrict bottom-up developments but gives appropriate room for manoeuvre (see Graffenberger; Cebotari and Mihály; Plüschke-Altof and Grootens in this volume). Society as a whole has to think about how we want to live in future, whether we just want to set minimum standards for the availability of public services (Kersten et al. 2017) or give every inhabitant of peripheral locations the same opportunities that people have in metropolitan areas. Such approaches could feature an extension of democratic participation at the regional level, regional coalition building, the development of new action strategies in the sense of community-based regionalism, local economic development (see Graffenberger in this volume), or even de-growth aspirations (e.g. Dax and Fischer 2017; Soja 2010, 9).

Dealing with uneven spatial development and growing sociospatial polarisation is a highly debated field in regional policy and spatial science. From a conceptual theoretical viewpoint, we see the main contributions of the book to this debate in a better understanding of five interrelated topics, which we will present in the following sections: (1) the regional policy paradox in the European Union, (2) the historical legacies leading to administrative centralisation trends in Eastern Europe, (3) globalisation and regional industrial restructuring causing further polarisation, (4) the mechanisms that produce inequalities, and (5) the production of inequalities through social practices and discourses. Based on these key topics, we argue for more agency centred research in peripheral contexts, which focuses on how actors, organisations and institutions on multiple scales shape the development of currently peripheralised places. In the final section of this chapter, we will also discuss the methodological and policy related issues linked to such an approach.

\section{The Regional Policy Paradox in the European Union}

This book-a collection of chapters based mainly on fresh empirical studies-discusses how European cohesion policy and Eastern European Countries' (CEE) regional policies have emerged and were 
institutionalised, and how the combination of various public interventions dealt with polarisation processes that have intensified during the last two decades. Several chapters help to better understand a certain paradox: that despite generous regional policies in the European Union-designed to contribute to a decrease in regional disparities-regional polarisation has intensified, especially in Southern, Central and Eastern Europe (Hadjimichalis in this volume). Interestingly, researchers are increasingly working with spatial policies and development themes including the concepts of 'territorial cohesion' and 'spatial justice'. However, these ideals can be achieved apparently less and less (Jones et al. in this volume).

This has undoubtedly challenged geographers, planners and political scientists, giving them the opportunity not only to combine expertise in demography, sociology, political science, classical, new and evolutionary economic geography but also in media studies, ethnography and other disciplines and their methodological armoury. Economic geographers in their own turn have increasingly turned their attention to applied questions of regional development, innovation, socio-spatial inequalities and spatial justice. The financial crisis inspired a shift towards critical approaches that manifested in a growing number of projects grounded in (neo-)Marxism and also in public involvement targeting sociospatial injustice (stemming from neoliberal practices and emerging centralised systems) in CEE in various ways - as was experienced in Margaret Thatcher's United Kingdom. Additionally, political renewal of authoritarian state power in some Visegrad countries accompanied by not only a seeming rise of neoliberal policies but also by nationalist critics towards global capitalism and Brussels provides a rich source of new material to critical geographers.

Up until recently, dominant economic geography theories (such as new economic geography or evolutionary economic geography) and related policy approaches such as growth pole strategies (see Benedek, Varvari, and Litan in this volume) argued that less-favoured, thus peripheralised regions would benefit from knowledge spillovers from and increased connectivity to growing centres. In contrast, recent studies indicate that the hierarchy-reinforcing effects of these features are considerably stronger than the convergence effects (Iammarino et al. 2017, 2). At the same time, critical political economists 
point to the limitations of growth-based development, which are linked to the limited availability of natural resources, a growing focus on personal satisfaction and well-being and new societal challenges, such as recent migration patterns or demographic change processes (Dax and Fischer 2017).

The last 20 years witnessed a shift in the rationale of regional policies from distributive policies to a globally oriented innovation policy putting regional competitiveness at the centre. Transnational corporations (TNC) and global organisations such as the World Bank have greatly impacted public governance to meet the needs of global capital. The prevailing rhetoric suggests that countries, regions and cities compete globally to offer companies the best environments. In parallel with globalisation, and also as its enabling and spurring factor, the 1980s already saw extensive deregulation: areas that used to be under state control (finance, telecom, media) were taken over by TNCs (Dicken 2015), even though they were still supported by their mother countries. In this discursive environment, Central and Eastern European innovation policies were hibernated during the transition period and, later after the accession, formulated following normative EU policies that remained very short-term in their outlook (Loewen and Schulz in this volume).

Cohesion Policy is above all trying to keep the EU economically competitive at the global scale, it is moving away from its traditional goal of promoting spatial cohesion by supporting development at the regional and local levels. (ibid.)

After EU accession, which brought large-scale cohesion and regional policy instruments to Eastern Europe, it would have been logical to see a decrease in regional differences; instead the discrepancies have grown (Finka 2007; Lang 2015). This somewhat paradoxical result can be explained by 'the blend of EU-driven regional policies in national political conventions. This appears to favour an ongoing territorial polarisation towards the large cities, which consequently leads to the peripheralisation of communities disengaged from development competition' (Brad 2018, 142). 
The general change in thinking has inevitably led to territorial restructuring of governance in response to global processes. An important trend in this regard is the emergence of so-called 'soft spaces', which alongside the tactical use of 'fuzzy boundaries' is related to a policy impetus to break away from the shackles of pre-existing working patterns. EU policies have contributed intensively to a breakaway from current administrative structures and to the creation of these soft spaces; they are leading in 'soft planning' (Purkarthofer 2016; Purkarthofer and Mattila 2018; Telle, Špaček, and Crăciun in this volume).

Another trend is the rising impact of EU sectoral regulations. The EU uses numerous directives and policy tools that have impact on territorial governance and spatial development. EU environmental legislation has been the most influential, but many other areas are becoming increasingly operative (Cotella 2017). The norms and regulations dictated from Brussels are frequently 'spatially blind' and may amplify economic problems in peripheries. As Paasi and Metzger $(2017,27)$ formulate it,

The world is much more complex than what can be grasped with the conceptual tools available at any given time.

Concepts that ignore spatial variety and the need for institutional capacity building and fail to involve local actors fall particularly short in CEE (Brad 2018; Loewen 2018; Cebotari and Mihály in this volume). Instead, development policies should be 'solidly grounded in theory and evidence, combining people-based with place-based approaches, and empowering local stakeholders to take greater control of their future' offering the most realistic and viable options for peripheralised regions (Rodríguez-Pose 2018, 206; see also Iammarino et al. 2017). More flexibility seems to be needed to better translate general EU policies to specific national, regional and local conditions. This would also help to introduce locally rooted and distributed policies (Iammarino et al. 2017; Jones et al. in this volume; Küpper et al. 2017) that address all dimensions of regional development alike and do not only focus on the economic realm. 


\section{EU Policies Meeting Historical Legacies: Discrepancies in Administrative Capacities}

Administrative decentralisation and the restoration of pre-war structures occurred in most CEE countries in the 1990s. Small local municipalities struggled to follow global economic processes and, as a result, discrepancies between national cores and peripheral regions increased. This, in turn, forced ministries to centralise services. The concept of new public management spread and CEE national public authorities themselves began to compete: regional and local operations were gradually taken under the direct control of ministries and central agencies, which starkly contrasts with devolution in Western European countries.

By the end of the 1990s, governing practices in CEE countries were affected by Europeanisation processes, and the pressure increased in the 2000s as a result of EU accession and harmonisation with the acquis communautaire. These changes had a far greater impact as CEE countries were not used to such rules and lacked, unlike their Western counterparts, established democracies. The negotiations regarding national and EU policies were mostly done in the interest of getting bureaucracy to function well on both sides. Since the period of negotiations was limited, capacity differences at lower levels in the administrative hierarchy were not taken into account. The commission mainly focused on increasing national level performance (Bachtler et al. 2014), which further increased the discrepancies between national and local/regional capabilities and, in fact, excluded the application of partnership and subsidiary principles.

The European Union tended to choose central governments to distribute pre-joining aid and to implement Structural Funds since it was sceptical of local/regional administrative capacities (Kungla 2007). For the implementation of EU regional development policies, new parallel administrative structures were established. This led to increased fragmentation and weakened the possibility of harmonising policies in CEE. It is evident that re-centralisation and the subordination of spatial planning to sectoral regulations came about under European Commission pressure. Since CEE politicians and officials wanted to optimise the funds 
they could get from the Structural Funds, they agreed to the expectations of Brussels without much objection (ESPON 2017).

Cohesion Policy has shifted in its overall aim from reflecting ideals of regionalisation and integration associated with the Europe of the Regions strategy to competitiveness and growth [...]. In CEE countries, these shifts coincided, firstly, with transition and EU accession, democratic and institutional capacity-building, and extreme underdevelopment of peripheral regions, and secondly with 'catching up', crisis-induced polarisation, political centralisation and regional competition. (Loewen and Schulz in this volume)

Furthermore, parallel spatial strategy processes have been started, so local development officers have been involved in designing a number of different, greatly overlapping local/regional strategy processes: LEADER, coastal fisheries, ERDF measures and county development strategies (see EMoF 2018). The latter received less attention since there have been no definite sources for their implementation. In addition, technical work (strategy and project writing) is usually outsourced to professional firms and these strategies are usually evaluated by city-based ministerial officials and consultants. Thus, capacity building focused mainly on the national level and the dissonance between CEE national and regional/local governance increased. The administrative systems in CEE dealing with EU measures became effective as soon as procedural regulatory and financial obligations were put in place, but had difficulties with programming, project selection as well as the implementation and integration of evaluation feedback (Bachtler et al. 2014). In addition, regions that have long faced serious decline and a loss of human resources are most probably less able to apply for and manage complex projects. As European policies seem to focus more on verifying expenses than on results, this does not yield the expected rise in knowledge and competitiveness, but has created, especially in the still weak CEE civil societies, a rise of quid pro quo (clientelist) relationships and an expansion of a professional 'project class' (Kovách and Kučerová 2006). Increased competition and specific criteria limit the number of potential applicants and strengthen the chances of organisations that are narrowly specialised to consult on certain measures. The consultancy firms that have built Europe-wide networks, including offices in Brussels, 
expand. Moreover, empirical studies suggest that individual Euroregion offices act more as gate-keepers to Structural Funds than as knowledge pools: despite the many cross-border projects that have been set up, information sharing and joint objectives have proven to be very limited and the capacity of public authorities differs greatly (Telle, Špaček and Crăciun in this volume) potentially leading to dysfunctional joint actions (Telle 2017; Špaček 2018).

Thus, it is unsurprising that EU post-accession investments have contributed to great regional differences in CEE countries, while turning convergence, partnership and subsidiarity principles into a farce. For the sake of accountability, the EU designed parallel administrative structures, which have weakened local and regional development capacities in CEE. To avoid or resolve sectoral conflicts, networking between national administrations is enforced, but this widens the gap with lower-level administrations. Generally, this calls for more administrative decentralisation in CEE countries. The cases of Czechia, Estonia, Hungary, Latvia, Slovakia and Romania show that the centralised EU regional policy cannot fulfil its objectives when there is a lack of capacity in localities and regions. Even national regional policy programmes are now too centralised and ultimately favour the development of urban cores (Raagmaa et al. 2014; Brad 2018; ESPON 2017; Loewen 2018; Špaček 2018; Loewen and Schulz in this volume).

Nevertheless, the example given by Nordic countries shows that strengthening local governments and compensating thin organisational density by bolstering and creating cooperative institutions can countervail peripheralisation processes (Isaksen 2001; Trippl et al. 2015).

\section{Globalisation and Regional Industrial Restructuring: Causes for Further Polarisation?}

During the last two decades, we have witnessed a triumph of neoliberal thinking. New narratives about globalisation and metropolisation spread not only among business leaders, but were also actively distributed by scientists (such as new economic geography by 
Krugmann and Venables 1995 and spiky world by Florida 2005) and influential policymakers (such as the new economic geography approach by the World Bank 2009). Sometimes, size has become the only criterion for the competiveness of enterprises, cities and even universities leading to various amalgamation processes in Europe and furthering the increase of regional disparities and spatial injustice.

Hudson and Pickles in their chapter draw parallels with the situation at the turn of the 1970s. There are several common features when comparing this early globalisation phase with CEE restructuring in the 1990s: privatisation, inflow of foreign capital and greenfield investments, takeovers and closedowns, the changing role of trade unions, let alone unemployment, environmental degradation and depopulation of old industries that dominated urban agglomerations. Still, there are also remarkable differences. While Northeast England can be considered a periphery of the UK, whose capital London became the global financial centre, industrial agglomerations in CEE are considered to be peripheries of peripheries and are hardly accessible from the European core. In the 1990s, globalisation and the neoliberal values associated with it were rapidly accepted by the political elites in several CEE countries (but not everywhere)- they wanted to rid themselves of their socialist legacy. During the transition period, so called 'cowboy capitalism' (a hyper-liberal variation of capitalism-see Gersemann 2005) caused massive unemployment, simultaneous collapse of existing social security systems and high crime rates.

Enterprises in CEE were privatised and often taken over by Western companies. Their management concentrated in the capitals; decisionmaking and R\&D operations were moved abroad, whereas the branches in Eastern Europe focused mainly on materials and labour (Woods 2011). At the same time, CEE governments lacked (and still do) the means as well as the rights (due to EU limitations on state aid) to boost local companies. Rising wages led to the closing of 
labour-intensive firms, which has been counterbalanced by asymmetric restructuring and concentration of service jobs into national centres.

In consequence, there is a huge difference between the volume of private $R \& D$ investments in Western and CEE countries. Future cohesion policy reforms need to take this 'innovation gap' into account and acknowledge the different national policy frameworks. So far, regional capacities for innovation-driven growth, such as institutions of higher education or high-tech enterprises, are more developed and more equally territorially distributed in old member states (Telle, Špaček, and Crăciun in this volume).

These observations show that, despite the high human development level in CEE (UNDP 2016), differences in the international division of work have remained. CEE developed from an elite industrial region in the socialist block to a semi-periphery, specialising in labour intensive subcontracting for Western companies. Factories located in peripheries were closed down and nearby settlements lost a major share of their population and housing. This has also directly affected migration patterns within the EU: millions of Eastern Europeans have resettled to (Western-)European metropolises in search for better wages and living conditions leaving their countries' peripheries without skilled workers and entrepreneurs. Moldova for instance lost over $40 \%$ of its total population during its never ending transition. A vicious circle of peripheralisation emerged: youth emigration from secluded rural areas, mining settlements or the former mono-structural industrial regions (Moldovan in this volume) has led to an imbalanced age structure, downsizing of services and less progressive local policy making. Migration processes raised problems not only in peripheral regions but also in central areas of immigration, where neoliberal dualised housing policies-i.e. public support to households and regions with higher wealth and income-left the problem of housing shortage unresolved producing polarisation and marginalisation at various scales simultaneously (Pósfai and Jelinek in this volume). 


\section{$4 \quad$ Understanding the Mechanisms that Produce Inequalities: $(\mathrm{Re})$ Conceptualising Macro-Processes}

Revealing the highly complicated mechanisms that produce sociospatial inequalities has given rise to a need to re-think the political economic approach in current debates, particularly in relation to the recent crisis (Hudson 2015). In consequence, the critical stream of political economy that considers unevenness inherent to capitalism has grown during the last years providing a deeper, more nuanced understanding of socio-spatial processes. In line with this thinking, several authors in this volume (Hudson and Pickles; Hadjimichalis; Pósfai and Jelinek) argue for re-politicising the economic-understanding polarities as the outcome of historically emerged, imbalanced yet dynamically changing power relations, that manifest in centralities/peripheralities in flows of capital, labour, knowledge etc.; moreover, they stress the complexity and interrelatedness of socio-spatial processes that produce unevenness. As Hudson and Pickles put it,

...the analysis and diagnosis of the regional problem of inequality and peripheralisation requires a complex articulation of forms of overdetermination, relationality and context that is both economic, cultural and political. (Hudson and Pickles in this volume)

The critical political economic conceptualisations of socio-spatial unevenness were inspired by the crises of capitalism-i.e. the structural problems of industrial regions in the 1970s and 1980s, the collapse of state socialism, and the 2008/2011 financial crash and economic downturn-which led to clear manifestations of socio-spatial inequalities (Christophers 2015; Hudson and Pickles; Hadjimichalis; Pósfai and Jelinek in this volume). Moreover, the crises also highlighted how macro-processes shape the everyday life and well-being of people making academic explanations available to the layperson and opening up macro-concepts to everyday life, local communities and individual agency 
(see Hadjimichalis; Pósfai and Jelinek; Moldovan in this volume) that should be considered as sources for social and economic recovery as well as for new academic concepts such as spatial justice.

What then are the powerful macro-processes that produced new socio-spatial inequalities and reproduced old ones under the recent crisis and the following recovery in Europe-as put forward by the authors of the book? The institutional context of global capitalism and its operating mechanisms (i.e. financialisation, the rentier economy and the reproduction of dependencies through debts), which unfolded unevenly and spread the risks and effects brought about by the crisis in a highly unequal way among households, places, regions and states, eventually recovered and produced an increasingly polarised system in the last few years (see Hadjimichalis; Pósfai and Jelinek in this volume). Understanding how financialisation got along with centralised control of capital flows, the reinforcement of inequalities and dependencies through uneven (unjust) access to loans and distribution of wealth, and how processes penetrated everyday life (e.g. through housing mortgage loans) elucidated the need for re-defining state policies in terms of goals, scope and spatiality.

Another process fuelling socio-spatial polarisation across Europe is migration (Lang 2011). Yet while it is considered a factor of growth in neoliberal development policies, for critical academic research it is a source of understanding of how everyday life, individual agency and structural processes are entangled and inequalities (re)produced. Thus, commuting 'out' or moving elsewhere is a structural process supporting peripheralisation-shrinking and ageing of the population, resulting in economic decline - and also an individual strategy to cope with such processes (see Moldovan in this issue). Recent migration trends are embedded in global, European and also sub-national divisions of labour but the consequences emerge locally. Thus, rural shrinkage can be understood relationally, linking macro-processes, regional economies, local (community) strategies and individual agencies. Discussing such issues in a CEE/Romanian/rural context, we take hints how national and EU policies are homogenising such spaces, and how limited community power is in such 'multiply peripheralised' places (see also Cebotari and Mihály in this volume). 


\section{$5 \quad$ The Production of Inequalities Through Social Practices and Discourses: The Value Added of Agency Centred Research in a Peripheral Context}

The socio-spatial polarisation and reproduction of peripheralities in Europe inspired research along various theoretical approaches and the reconceptualisation of peripheralisation as a multidimensional, multiscalar process relating to various places and agents simultaneously (PoScoPP 2015). This dynamic and relational understanding of uneven sociospatial processes raised more concern among scholars not only about the spatiality of structural shifts, power and social justice, but also about their varied 'landscape' produced by locally embedded social practices and agencies. Researching socio-spatial inequalities through this lens is a source of knowledge on the struggles, strategies and practices of institutions, firms, individuals and communities that produce different peripheralities, and thus for critiquing the blindness of dominant concepts of regional development when it comes to diversity and local/regional agency (Massey 2004; Hadjimichalis and Hudson 2014; Pike et al. 2017). Moreover, research focused on a peripheral context (Graffenberger; Plüschke-Altof and Grootens; Mihály and Cebotari in this volume) helps not only to understand and re-conceptualise the making of inequalities, but also to re-consider individual and institutional strategies as well as community actions as relevant responses to decline and crisis, which are worth embracing in new, more just policy measures.

Social practices are shaped directly or indirectly by discourses and underlying power relations (see Brad 2018; Hadjimichalis; PlüschkeAltof and Grootens in this volume). Thus, understanding the ways in which terms, notions, definitions are produced discursively and reacted to by various agents in peripheries (and beyond) reveal how the hegemonic values and norms of neoliberal capitalism are produced, translated into policies and practices (while pretending to be politically 'neutral'), and how they penetrate everyday life (re)producing unevenness. 
Institutional practices/agencies and the discursive processes shaping them are drivers reproducing inequalities; yet such processes involve many dimensions and scales/places. While researching the power relations of agents acting at various scales, we also should see how inequalities unfold and are reproduced at particular scales and within particular institutional contexts, as is discussed by Kuus, Loewen and Schulz, as well as Telle, Špaček, and Crăciun in this volume. Analysing the uneven production and flow of expertise related to EU regional policies in transnational discourses, Kuus highlights the methodological problem of giving '.. an analytically rigorous and empirically nuanced account of these processes' (Kuus in this volume), due to the strong national bias of our analytical toolkit. To overcome this, Kuus suggests a flexible, transnational approach to understand economic, political and symbolic peripherality.

Researching inequalities from the periphery through social practices and agency has further empirical, methodological and epistemological lessons. Revealing the institutional (and thereby socio-cultural) aspects of division of labour and changing power relations under global capitalism to get more sophisticated knowledge on uneven development has become mainstream in social geography (Massey 1984; Hudson 2015). (i) The spatial embedding of firms was a lens through which the social relations/practices producing inequalities have been studied since the early 2000s (Coe and Yeung 2015). Yet we still have little knowledge on firms in peripheries, even though firms in peripheries do innovate by overcoming local and regional deficits through networking beyond their local context. Analysing this process, Graffenberger in this volume links the problem of peripheralisation to innovation debates, and discourses on culture, institutions and structural change in economic geography; moreover, he refutes the narrative of periphery as a place of no innovation and highlights the multiple agencies behind it. By doing so, he provides inputs for articulating the specific needs of such firms and places, and argues for more varied state policies from developing ICT infrastructure to support networks of knowledge transfer, and also for considering local firms as agents of change. (ii) Communities are also considered the makers of local processes/spaces, and have become 
a popular subject for academic research in the West; yet the conceptualisation of community agency rested largely on Western experiences, something that should be looked at in light of differences in the potentials and limits of communities in European peripheries (Loewen 2018; Cebotari and Mihály in this book). Analysing CEE community projects, Cebotari and Mihaly stress the centrality of state (municipal) agency, represented by local leaders (mayors), which is not only the result but also a driver of peripheralisation; while it enhances local state capacities, the lack of local social involvement questions the social sustainability of local initiatives, and their potential for further, cumulative change, thereby easing peripherality. Thus, the methodological problem of (not) differentiating between communities and municipalities/local state in EU policy measures hides a deeper problem of power relations: state dominance and lack of empowerment in peripheral localities in CEE. (iii) The individual agency of local people has also been widely discussed challenging structuralist arguments on understanding the mechanisms of uneven development (Massey 1984, 2004), and recently as a source of knowledge on the diversity of local/regional trajectories and a resource for putting places that are lagging behind on a new track (Rodríguez-Pose 2013). Although the potential of local agency such as leadership and image making has gained more attention and positive connotations, studies from CEE peripheries highlight the limits of such connotations. Plüschke-Altof and Grootens argue in their chapter that local leaders struggle with enhanced responsibilities and related risks in rural Estonia-e.g. by 'idealising' their localities while changing their image-but their scope is limited heavily by the structural context of multiple dependencies and the lack of resources. Such conclusions should make scholars wary of articulating ideas, arguments, concepts on structures and agencies that might play out very differently in core/ peripheral/semi-peripheral contexts; e.g. thinking about 'successful' local leadership as a resource for counteracting peripherality, and also as a neoliberal argument that places the socio-spatial consequences of neoliberal policies in the responsibility of local actors. 


\section{Methodology, Positionality and Policy Issues}

In our view, the book contributes to a better understanding of socio-spatial polarisation as a relational, multi-dimensional and multi-scalar concept. This understanding includes processes of peripheralisation and (de-)centralisation, highlighting not only economic but also infrastructural, political as well as social and discursive aspects. The book also provides alternative viewpoints working out (1) the political geographies of spatial injustice, (2) current forms of policy and governance in relation to socio-spatial polarisation, and (3) different approaches to regional and local development. Many chapters in the book are based on interactions (interviews) with local, regional and national politicians and policy makers, companies, NGO leaders and also the general public. This approach explains the functionality and underlying power structures related to dominant normative assumptions, conceptualises what territorial cohesion and spatially just policies actually mean to different stakeholders and, last but not least, understands which role academics and academic concepts can play for the development of local initiatives.

At the moment, it seems that in most cases priority is still given to the economic dimension of regional development and complex problems are simplified to technical questions. In contrast, the normative concept of 'spatial justice' with its holistic approach can add to a more nuanced understanding of regional development and territorial cohesion as it seeks to ensure 'access to and use of resources' for future generations and encourages locally and regionally rooted solutions without neglecting distinctive structural problems (Pike et al. 2007, 1264; see also Jones et al. in this volume).

This book offers a specific epistemic lens for understanding growing socio-spatial inequalities and the diverse and interrelated processes behind it: the authors lived and worked in contexts in which peripheralisation and peripherality are experienced in everyday life. Seeing the 
world from inside places hit by economic decline, powerlessness, social and environmental crisis and seeing how neoliberal capitalism is 'lived' there can be used as sources for motifs to make new claims, arguments and challenge concepts and theories attached to powerful centres of knowledge production. This entanglement of the mundane and the academic in a researcher's work is inspiring, and being constantly aware of it is a source of being reflective, of placing ourselves/our work within academic life and being attached to and arguing for/against existing concepts and theories, as well as to see our work in a 'wider world' in which our projects are seen, critiqued or praised for (not) being beneficial to those who have been researched. Moreover, our reports might have far-reaching effects on socio-spatial processes by supporting various policies. Here we should always keep in mind the developmentroutes/detours, milestones, relations - of our own academic career to relate our work to the 'world out there' (discussed explicitly by Hudson and Pickles in this volume).

Being part of the world in which we work also raised methodological concerns. One key issue pointed out by some authors in this book is the agency of the researcher deeply embedded in the studied field (regions, places, institutions) that might shape the interpretations of local processes and the related actions. Moreover, while doing fieldwork and relying on information from local actors brings about knowledge that is contingent and fluid, reflecting various viewpoints and realities, there is no fast and easy way to grasp the complexity of strategies, practices, relations linked to a place. We need to see the whole picture (always in motion) while understanding individual agencies and their structural contexts (including our own role) (see e.g. Kuus; Plüschke-Altof and Grootens). Revealing the complex relations that produce peripheralities might support moving beyond case studies (that either provide best practices or places of experimentation to achieve them) and getting closer to diverse realities and policies to address community and individual needs that are outside core areas. 


\section{References}

Bachtler, John, Carlos Mendez, and Hildegard Oraže. 2014. "From Conditionality to Europeanization in Central and Eastern Europe: Administrative Performance and Capacity incl. Cohesion Policy." European Planning Studies 22 (4): 735-57. https://doi.org/10.1080/09654313.2013. 772744 .

Brad, Alexandru. 2018. "When Romania Met the Cohesion Policy: Regional Governance Between National Conventions and European Ideals." Administrative Culture 18 (2): 127-48.

Christophers, Brett. 2015. "Geographies of Finance II: Crisis, Space and Political-Economic Transformation.” Progress in Human Geography 39 (2): 205-13. https://doi.org/10.1177/0309132513514343.

Coe, Neil M., and Henry Wai-Chung Yeung. 2015. Global Production Networks: Theorizing Economic Development in an Interconnected World. Oxford: Oxford University Press.

Cotella, Giancarlo. 2017. "How Europe Hits Home? Comparing the Impact of the EU Legislation, Policy and Discourse on Its Member States' Territorial Governance and Spatial Planning Systems.” Warsaw Regional Forum (conference contribution).

Dax, Thomas, and Michael Fischer. 2017. "An Alternative Policy Approach to Rural Development in Regions Facing Population Decline." European Planning Studies 26 (2): 297-315. https://doi.org/10.1080/09654313.201 7.1361596.

Dicken, Peter. 2015. Global Shift: Mapping the Changing Contours of the World Economy. 7th ed. New York: The Guilford Press.

ESPON. 2017. "COMPASS—Comparative Analysis of Territorial Governance and Spatial Planning Systems in Europe." Draft Materials of Estonian, Latvian, Lithuanian, Finnish, Dutch and Slovenian Case Studies. https:// www.espon.eu/planning-systems.

EMoF-Estonian Ministry of Finance. 2018. "Arengu ruumiline ja strateegiline kavandamine, sh regionaaltasandi funktsioonid ruumilise arengu suunamisel.” [Spatial and Strategic Planning of Development, Including Regional Level Functions in the Direction of Spatial Development]. Final Report. Tallinn. https://planeerimine.ee/static/sites/2/arengu-ruumiline-ja-strateegiline-kavandamine.pdf. 
Finka, Maroš. 2007. "Territorial Cohesion-Between Expectations, Disparities and Contradictions." In Territorial Cohesion. German Annual of Spatial Research and Policy 2007, edited by Dietmar Scholich, 23-39. Berlin: Springer.

Florida, Richard. 2005. "The World is Spiky." Atlantic Monthly 10: 48-51.

Gersemann, Olaf. 2005. Cowboy Capitalism: European Myths, American Reality. Washington: Cato Institute.

Hadjimichalis, Costis, and Ray Hudson. 2014. "Contemporary Crisis Across Europe and the Crisis of Regional Development Theories." Regional Studies 48 (1): 208-18. https://doi.org/10.1080/00343404.2013.834044.

Hudson, Ray. 2015. "Uneven Development, Socio-Spatial Polarisation, Political Responses." In Understanding Geographies of Polarization and Peripheralization: Perspectives from Central and Eastern Europe and Beyond, edited by Thilo Lang, Sebastian Henn, Wladimir Sgibnev, and Kornelia Ehrlich, 25-39. New Geographies of Europe. Basingstoke: Palgrave Macmillan.

Iammarino, Simona, Andrés Rodríguez-Pose, and Michael Storper. 2017. "Why Regional Development Matters for Europe's Economic Future." Working Paper 07/2017, Publications Office of the European Union, Luxembourg.

Isaksen, Arne. 2001. "Building Regional Innovation Systems: Is Endogenous Industrial Development Possible in the Global Economy?" Canadian Journal of Regional Science 24 (1): 101-20.

Keim, Karl-Dieter. 2006. "Peripherisierung ländlicher Räume.” Aus Politik und Zeitgeschichte 37: 3-7.

Kersten, Jens, Claudia Neu, and Berthold Vogel. 2017. "Gleichwertige Lebensverhältnisse. Mindeststandards allein genügen nicht." Special Issue Stadtland, Der neue Rurbanismus. Arch + 228: 188-91.

Kovách, Imre, and Eva Kučerová. 2006. "The Project Class in Central Europe: The Czech and Hungarian Cases." Sociologia Ruralis 46 (1): 3-21. https:// doi.org/10.1111/j.1467-9523.2006.00403.x.

Krugman, Paul, and Anthony Venables. 1995. "Globalization and the Inequality of Nations.” The Quarterly Journal of Economics 110 (4): 857-80. Kühn, Manfred, and Thilo Lang. 2017. "Metropolisierung und Peripherisierung in Europa-eine Einführung." Europa Regional 4/2015 (2017): 2-14.

Kühn, Manfred, Matthias Bernt and Laura Colini. 2016. "Power, Politics and Peripheralisation: Two Eastern German Cities." European Urban and Regional Studies 24 (3): 1-16. 
Kungla, Tarvo. 2007. Patterns of Multi-Level Governance in Europe: The Challenge of the EU's Enlargement. Tallinn: Tallinn University of Technology. Küpper, Patrick, Stefan Kundolf, Tobias Mettenberger, and Gesine Tuitjer. 2017. "Rural Regeneration Strategies for Declining Regions: Trade-Off Between Novelty and Practicability." European Planning Studies 26 (2): 229-55. https://doi.org/10.1080/09654313.2017.1361583.

Lang, Thilo. 2011. "Regional Development Issues in Central and Eastern Europe: Shifting Research Agendas from a Focus on Peripheries to Peripheralisation?" In Geography in Visegrad and Neighbour Countries, edited by Agnes Eröss and David Karcsonyi, 57-64. Budapest: Geographical Research Institute HAS.

Lang, Thilo. 2013. "Conceptualizing Urban Shrinkage in East Germany: Understanding Regional Peripheralisation in the Light of Discursive Forms of Region Building." In Peripheralization: The Making of Spatial Dependencies and Social Injustice, edited by Andrea Fischer-Tahir and Matthias Naumann, 224-38. Wiesbaden: Springer.

Lang, Thilo. 2015. "Socio-Economic and Political Responses to Regional Polarisation and Socio-Spatial Peripheralisation in Central and Eastern Europe: A Research Agenda." Hungarian Geographical Bulletin 64 (3): 17185. https://doi.org/10.15201/hungeobull.64.3.2.

Loewen, Bradley. 2018. "From Decentralization to Re-Centralization: Tendencies of Regional Policy and Inequalities in Central and Eastern Europe." Administrative Culture 18 (2): 103-26.

Massey, Doreen. 1984. Spatial Divisions of Labour. London: Macmillan.

Massey, Doreen. 2004. "Uneven Development: Social Change and Spatial Divisions of Labor." In Reading Economic Geography, edited by Trevor J. Barnes, Jamie Peck, Eric Sheppard, and Adam Tickell, 111-25. Oxford: Blackwell.

Paasi, Anssi, and Jonathan Metzger. 2017. "Foregrounding the Region." Regional Studies 51 (1): 19-30. https://doi.org/10.1080/00343404.2016.1 239818.

Pike, Andy, Andrés Rodríguez-Pose, and John Tomaney. 2007. "What Kind of Local and Regional Development and for Whom?" Regional Studies 41 (9): 1253-69. https://doi.org/10.1080/00343400701543355.

Pike, Andy, Andrés Rodríguez-Pose, and John Tomaney. 2017. "Shifting Horizons in Local and Regional Development." Regional Studies 51 (1): 46-57. https://doi.org/10.1080/00343404.2016.1158802. 
Purkarthofer, Eva. 2016. "When Soft Planning and Hard Planning Meet: Conceptualising the Encounter of European, National and Sub-National Planning." European Journal of Spatial Development 61. https://research. aalto.fi/files/4298206/Refereed61.pdf.

Purkarthofer, Eva, and Hanna Mattila. 2018. "Integrating Regional Development and Planning Into 'Spatial Planning' in Finland: The Untapped Potential of the Kainuu Experiment." Administrative Culture 18 (2): 149-74.

PoSCoPP-Research Group Production of Space in the Context of Polarization and Peripheralization. 2015. "Understanding New Geographies of Central and Eastern Europe." In Understanding Geographies of Polarization and Peripheralization. Perspectives from Central and Eastern Europe and Beyond, edited by Thilo Lang, Sebastian Henn, Wladimir Sgibnev, and Kornelia Ehrlich, 1-21. New Geographies of Europe. Basingstoke: Palgrave Macmillan.

Raagmaa, Garri, Tarmo Kalvet, and Ragne Kasesalu. 2014. "Europeanization and De-Europeanization of Estonian Regional Policy." European Planning Studies 22 (4): 775-95. https://doi.org/10.1080/09654313.2013.772754. Rodríguez-Pose, Andrés. 2013. "Do Institutions Matter for Regional Development?” Regional Studies 47 (7): 1034-47. https://doi.org/10.1080 /00343404.2012.748978.

Rodríguez-Pose, Andres. 2018. "The Revenge of the Places That Don't Matter

(And What to Do About It)." Cambridge Journal of Regions, Economy and Society 11 (1): 189-209. https://doi.org/10.1093/cjres/rsx024.

Soja, Edward. 2010. Seeking Spatial Justice. Minneapolis: University of Minnesota Press.

Špaček, Martin. 2018. "Multilevel Cross-Border Governance in the CzechSaxon Borderland: Working Together or in Parallel?” Administrative Culture 18 (2): 175-202.

Storper, Michael. 2014. "Keys to the City: How Economics, Institutions, Social Interaction, and Politics Shape Development." Berkeley Planning Journal 27: 122-24.

Telle, Stefan. 2017. "An Institutionalist View on Experimentalist Governance: Local-Level Obstacles to Policy-Learning in European Union Cohesion Policy." European Journal of Spatial Development 66. http://urn.kb.se/ resolve?urn=urn:nbn:se:norden:org:diva-5045.

The World Bank. 2009. "Reshaping Economic Geography." World Development Report. http://documents.worldbank.org/curated/en/730971468139804495/ pdf/437380REVISED01BLIC1097808213760720.pdf. 
Trippl, Michaela, Björn Asheim, and Johan Miorner. 2015. "Identification of Regions with Less Developed Research and Innovation Systems." Papers in Innovation Studies No. 2015/1. Lund University: CIRCLE-Center for Innovation, Research and Competences in the Learning Economy. http:// wp.circle.lu.se/upload/CIRCLE/workingpapers/201536_Asheim_et_al.pdf. UNDP. 2016. "Human Development Report 2016." United Nations Development Programme. http://hdr.undp.org/sites/default/files/2016_ human_development_report.pdf.

Woods, Michael. 2011. "Regions Engaging Globalization: A Typology of Regional Responses in Rural Europe." Paper Presented to the AngloAmerican-Canadian Rural Geographers Quadrennial Conference, Manitoba, July 2011. http://www.derreg.eu/system/files/Regions\%20 Engaging\%20Globalization.pdf.

Open Access This chapter is licensed under the terms of the Creative Commons Attribution 4.0 International License (http://creativecommons. org/licenses/by/4.0/), which permits use, sharing, adaptation, distribution and reproduction in any medium or format, as long as you give appropriate credit to the original author(s) and the source, provide a link to the Creative Commons license and indicate if changes were made.

The images or other third party material in this chapter are included in the chapter's Creative Commons license, unless indicated otherwise in a credit line to the material. If material is not included in the chapter's Creative Commons license and your intended use is not permitted by statutory regulation or exceeds the permitted use, you will need to obtain permission directly from the copyright holder.

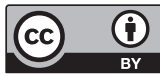




\title{
15
}

\section{Translating Scientific Results: Encouraging Reflective Policies as a Chance for Change}

\author{
Sorin Cebotari, Tomas Hanell and Thilo Lang
}

\section{Introduction}

Writing a policy recommendation chapter is both challenging and rewarding at the same time. On one hand, it requires us to translate complex academic research into practical policy suggestions. On the other hand, it offers an understanding of purpose for the researcher since a policy chapter is one of the few gates through which social scientists can contribute to shaping a policy discourse. Given this context, our main aim is to formulate clear and comprehensible policy recommendations drawing from the existing academic debate and research presented in the previous chapters.

While the results of processes of polarisation and peripheralisation are mostly visible in remote, isolated or excluded spaces, the dynamics fuelling these processes connect to all levels of policy-making.

\section{S. Cebotari ( $\square)$}

Research Center for Sustainable Development, Faculty of Geography, Babeș-Bolyai University, Cluj-Napoca, Romania 
It is important, therefore, to consider policy-making, in this context, as a collection of processes which transcend sectoral and administrative boundaries in a multi-actor setting. Given that understanding, we would like to highlight three distinct administrative levels on which the problem of uneven spatial development is tackled. Firstly, the EU level strikes as the one where the polarisation problem is highly debated and triggers policy action across different EU level actors and institutions. Through the mechanisms of Cohesion Policy, and lately also including some mechanisms of innovation policy (see Loewen and Schulz as well as Telle, Špaček and Crăciun), EU level policy-makers aim to address existing regional discrepancies. While this discussion at the EU policy level is clearly getting more and more attention (see Jones et al.), national states retain the sovereignty to decide upon how to redistribute EU and national funding to tackle peripheralisation. Member states' interest in keeping financial management tools at their disposal is down to a number of reasons. However, it is clear that by doing so, member states also ensure a possibility to shift EU policy goals to their own, national political aims. In this respect, especially in the case of CEE countries, a series of different policies emerged with the main (or at least declared) goal of reducing spatial and income inequalities and promoting even development (see Benedek, Varvari and Litan as well as Posfai and Jelinek). While not with the same amount of political and economic power, regional and local levels offer us the possibility to see the way in which policies (EU or national) interact with local communities and decision makers. In this way, we can see these policies in action (or inaction) (see Moldovan, Cebotari and Mihály, Graffenberger as well as PlüschkeAltof and Grootens). To a certain degree, all these administrative levels

\section{T. Hanell}

University of Helsinki, Helsinki, Finland

T. Lang

Leibniz Institute for Regional Geography, Leipzig, Germany

T. Lang

Global and European Studies Institute, University of Leipzig,

Leipzig, Germany 
are connected through the policy framework. It is important, therefore, to observe how each level of policy making and policy implementation evolves, but at the same time to consider all of them inter-linked and dependent upon each other.

The first three sections of this chapter discuss the main shortcomings and possible improvements of existing public policies at the EU, national and combined, regional and local level. Based on this discussion, the final section outlines five policy recommendations to address rising polarisation and peripheralisation at both the EU and the member state level.

\section{Polarisation Viewed by EU Policy-Makers}

There is growing interest among researchers in EU-level policies that aim to improve territorial cohesion, thus reducing socio-economic disparities within the EU. This book, while looking at specific contexts mostly from Central and Eastern Europe, has several chapters that discuss the EU policy framework, identifying a series of challenges related to Cohesion Policy and subsequent successful implementation of territorial cohesion goals.

One of the serious issues with Cohesion Policy, as discussed by Jones et al., is the fact that, while it is a well-intended policy, territorial cohesion remains an elusive and complex concept. This elusive character of the concept leaves it open to different interpretations, thus it is often misused or manipulated in order to promote specific (or even different) priorities in different national/regional contexts. Even at the level of the European Union, it seems that Cohesion Policy lacks consistency and, therefore, a clear understanding of the pursued goals. It is true that continuous changes in the policy are required given the varying national contexts, thus we end up having different programme goals in different states to suit local needs. At the same time, there must be an over-arching understanding of what Cohesion Policy aims at. Probably the top-rating priorities are to design a consistent policy and to avoid having a series of place-based cohesion policies with different local understandings of programme goals (Telle, Špaček and Crăciun). Another shortcoming of Cohesion Policy is its convergence with innovation policies as presented 
by Loewen and Schulz. The authors stress that convergence between the two policies can lead to the over-centralisation of management authorities at the national level. This in turn would offer national authorities control over the selection and implementation of projects. Given the availability of material and knowledge resources in metropolitan and urban centres, this type of management would benefit the core regions within CEE countries. Although well intentioned and timely thought, this convergence can in this way decrease the positive effects of Cohesion Policy by re-orienting it towards strict economic development, thus neglecting its moderating force across the EU. Based on these observations, we can see that Cohesion Policy remains an elusive and complex concept which can lead to different interpretations by different national authorities. Its convergence with innovation policies makes it more prone to local misinterpretations that in the end might steer Cohesion Policy away from the territorial convergence goal altogether.

Given these major challenges, we believe that EU level policy-makers have to consider a series of changes within Cohesion Policy in order to ensure its efficiency and keep it focused on the reduction of socioeconomic disparities across the EU. One important measure in this direction would be a better conceptualisation of Cohesion Policy goals. A clear outline of what Cohesion Policy means and what it is expected to deliver would help national policy-makers produce better mechanisms of fund management and resource allocation. Further clarification of the policy's goals should look at how it was meant to interact with other policies (for our discussion considering innovation policy). There must be a clear separation between Cohesion Policy and any other policy working in a similar direction. For example, although innovation policy could and should serve as possible mechanism to promote economic development, it should not overshadow the social and environmental goals underlined in Cohesion Policy. In this way, Cohesion Policy needs to be updated such that it adds more clarity regarding its goals and objectives. When reconsidering Cohesion Policy at both the conceptual and the mechanism level, we have to be sure that it gives enough insight and clarity that national policy makers are able to follow the policy guidelines without transforming the opportunities offered by it into tools of political struggle at the national level. 


\section{Polarisation Viewed by Member State Policy-Makers}

It would be mistaken to believe that national policy makers do not consider reducing spatial inequalities a priority for their government. Regardless of the country specific context, national level policy-makers within the CEE region do devise instruments to reduce intra and inter-regional disparities. The question remains, however, how effective are those policies and what can be done to improve them?

It is often the case that policies devised by national authorities are based on strict economic analysis and neglect the complexity of uneven development. In Romania for example, national policies aimed at reducing disparities within the regions in fact have widened the gap. National policy-makers chose to focus on developing core cities, hoping for positive spillovers to foster development throughout the region. Discussed in detail by Benedek, Varvari and Litan, it seems that sustaining large urban agglomerations does not reduce peripheralisation within counties with large urban centres. On the contrary, this approach seems to have contributed to the widening of regional inequalities. Hungarian housing policy offers another example of a national-level policy that reproduces socio-economic discrepancies regardless of the assumed goal of reducing them. As presented by Posfai and Jelinek, Hungarian housing-related benefits are socially but not spatially distributed; however, the management of these benefits is delegated to local municipalities, which, due to a lack of national scale engagement, reproduces spatial discrepancies. Overall, the authors argue that housing policies in Hungary, as they work currently, promote home ownership in the peripheries of the core for the upper middle class. In this way, the policy simply perpetuates existing spatial inequalities that exclude from the scheme those people who need housing benefit the most.

These two examples point to a structural problem when analysing national-level policies. Often these are designed with shortterm political gains in mind. Given the ambiguity of EU-level policy mechanisms, it is left for national-policy makers to formulate policies that promote territorial and social convergence. 
National political actors are also tied to specific electoral cycles, so the immediate results may surpass long-term effects once a policy is designed. A couple of improvements could be made here to ensure more impactful policies to reduce regional and social disparities. Firstly, in the case of EU funds, national policy makers must ensure that Cohesion Policy goals are also clearly formulated within every national policy. In this way, the guiding principle of national-level policies should also coincide with the outlined goals of Cohesion Policy. Secondly, moving beyond the policy design stage, national authorities have to get more actively involved in regional development. This could be ensured by bringing together national and local authorities, representatives of the non-governmental sector and civic organisations in order to analyse and change implemented policies. National-level policy making is crucial in bridging the gap between EU-level policy goals and local implementation and acceptance of these goals. National-level policy makers are here probably the most important link in promoting (or even compromising) the idea of even development.

\section{$4 \quad$ Local-level Policy Effects and Pushbacks}

Regional and local actors are rarely considered active policy-makers, least so in CEE countries. Given the lack of serious policy mechanisms, their role is often a practical one, accessing funding from the national level and complying with policy requirements. It is important, however, to consider this administrative level as true reflection of a policy's efficiency and success. It is often down to regional or local actors to implement the policy and observe the changes it produces.

In some cases, local actors assume an active role in changing the situation of their locality. This is often viewed as healthy and beneficial; local leadership is, therefore, praised by national authorities and considered to be a driver for locally based development. While certainly valuable, local leadership also gives national authorities an excuse to shift the responsibility for structural problems to local actors. This issue is well described by Plüschke-Altof and Grootens discussing the Estonian 
context where, in some areas, local leadership assumes an important role in shaping the image of the locality, trying to move beyond the periphery label. This active involvement offers at the same time an ideal opportunity for national policy makers to shift the responsibility to the local level thereby minimising the importance of their involvement and overlooking structural problems that cannot be solved at the local level.

The role played by national authorities is of utmost importance since no real progress can be made without structural changes and substantial support for less developed regions. As pointed out by Graffenberger, inclusive access to high-performance information and telecommunication technology (ICT) must be considered a major component of (national) infrastructural as well as regional development policy. In this respect, national authorities have to assume an active role in ensuring a dense network of connections within and especially outside the region for local actors since it could foster local development, exchange of ideas and experiences and further the innovation capacities of these actors.

While in some cases local leadership is effective and welcomed, more often than not local communities are deprived of real political or economic instruments to influence local development processes. This is a very serious challenge for local development throughout the CEE region. If policies follow a strict top-down logic, with only national authorities deciding what type of projects better fit regional and local development, we risk ending up in situations where local authorities implement projects only for the sake of accessing funding, but lacking any serious impact on local development. As pointed out by Moldovan as well as by Cebotari and Mihaly, in the cases of Hungary and Romania, the policy direction designed by national authorities does not take into account local needs or the way those needs might be shaped. This is the reason some of the projects implemented through EU funding still fall short of reducing disparities between centres and peripheries.

While local actors rarely play an active part in the policy-making process, it is still important to consider them important to the policy process. A series of policy proposals could be formulated here to increase the involvement of local actors. The first thing to do is to support local leadership by taking a structural approach involving central, regional 
and local institutions. Simply considering local leaders as a good example does not suffice. State actors and policies have to provide a supportive environment for local action by investing in local infrastructure and providing a foundation for local actors and extra-regional actors to interact. By doing so, policies aiming to support local development have to consider a closer relationship with local authorities and the non-governmental sector. The design, implementation and evaluation of every policy should also involve local actors so that it ensures fitness to the local context.

\section{$5 \quad$ Policy Recommendations: Five Guiding Points}

Presenting the main challenges and possible alternatives to current administrative lines, we would like to suggest a series of five policy proposals that could contribute to improving the existing policy framework.

\section{Re-connecting Cohesion Policy to cohesion}

Cohesion Policy is one of the most powerful policy instruments available at the EU level that explicitly aims to reduce territorial disparities and promote even development. While it has strong financial backing and institutional support, Cohesion Policy encountered a series of challenges that had to be addressed in order to ensure its efficiency during the following programming periods. In that respect, we would like to advocate three major improvements that would strengthen the important role played by Cohesion Policy within the EU construct.

- Re-centre Cohesion Policy on the idea of spatial justice. As a pan-EU policy, Cohesion Policy must maintain a high degree of flexibility, ensuring adaptation to local contexts. This flexibility should rely on a clear understanding of the policy's main goal, which, in our opinion should draw from the idea of socio-economic justice and support. 
Clarifying this aim within the policy text should ensure consistency between the practical goal of the policy and the mechanisms it uses to achieve it.

- Open Cohesion Policy up for wider participation during the policy design stage. While member states are represented through the European Council, it is important that regions and intra-regional actors also get engaged throughout the policy design and evaluation stages. As there are different regional understandings of Cohesion Policy, it might be useful to integrate a wider range of views from regional leaders and local actors. Such an initiative would offer an alternative and complementary view on Cohesion Policy to the one formulated within the European Commission, EU Parliament or the Council of the EU. This would give wider legitimacy to the policy and lead to more coherence with the policy goals of regional leaders.

- Sustaining good governance and institutional capacity building beyond its commitment to support less developed regions, Cohesion Policy instruments must also encourage a specific type of development. Simple financial aid can encourage economic development. In order to maintain this development and diversify its effects into the social and political spheres as well, financial mechanisms must be combined with institutional support and sustainability goals. In this way, Cohesion Policy would also target lasting change within the less developed regions.

2. Increasing the participation of local and regional actors within national policy-making processes: let "place" also steer the design of policy

While local and regional actors are the main beneficiaries of regional development policies, they are also often excluded from decisionmaking processes. In addition to the standard public consultations, we suggest a series of three policy measures that could improve the participation of local actors, thereby granting the policies consistency, legitimacy and local input. 
- Establish a co-decision instrument to ensure shared input during the policy design stage. To do this, central authorities would have to establish a regional platform for discussion and consultation that would include, in addition to local authorities, non-governmental organisations, business representatives, civil society organisations, etc. Recommendations from this body could later serve as input for different regional based policy approaches.

- Reduce the required documentation and bureaucratic procedures related to funding applications for local actors. As a result of the complex requirements and limited capacities of local actors, they often avoid applying for EU funding. Simplifying the procedures and focusing on qualitative evaluation of projects would allow for more flexibility and understanding of local needs. To avoid the mismanagement of funds, the administrative burden should be given to national, regional and local authorities, leaving applicants to focus on the qualitative part of their project application. Another improvement would be ensuring a resilient online system for project pre-application. That would allow easier access to data for national authorities, an easier application process for local actors and a quicker evaluation process of the project proposals.

- Give local authorities more tools to steer and manage the EU and national funding. Given their connection and contextual understanding of the existing challenges, local authorities are probably best placed to consider the distribution of funds to support local development. Currently, local authorities have little to no tools to influence the way in which funds are managed and allocated. There have been many instances when local actors have accessed just for the sake of attracting more money to the locality. However, as we saw in the chapters of this book, in most cases these types of projects cannot produce locally based, long-lasting development.

3. National level engagement in building a supportive infrastructure at the regional and local level 
In order to create a supportive environment for locally based development, national authorities should be encouraged to go beyond policy frameworks and consider direct involvement to support expensive programs or to manage national programmes for which local authorities lack human and financial capital.

In some cases, such a presence could be translated into state-owned social housing in less well off areas, thus offering affordable housing to lower income inhabitants. It is also important to consider increased support for educational and healthcare services in these areas since it is often beyond the capacities of local authorities to provide appropriate incentives for qualified personnel to move to less developed areas. Hence, there is a need for the central government to step in and ensure support for them.

Another effective way to encourage local participation and to develop remote localities is to provide the required infrastructure and networking possibilities at the local level. We highlight here the clear need for investments in ITC and networking infrastructures at the regional level to promote inter-regional exchange and cooperation. Access to an effective ITC infrastructure would allow local agents to connect with agents from across the region as well as national legislators at the EU level. This would enable local actors to increase their visibility, to acquire outside knowledge and experience, to connect to possible suppliers or customers and in the end to ensure locally based development.

\section{Increasing human capital at the local level}

The basis for sustainable development is local capital, financial and human capital being equally important for local communities in order to change the dynamics of peripheralisation. While financial capital can be 'outsourced,' local human capital is crucial to realising lasting local development. It can serve as a foundation for increasing participation, community level decision making, proper management of financial resources or strategic investments for longer periods of time. In order to boost local human capital, a few public policies could be considered: 
- Allow for training and educational activities within every project financed by the European Union. As we saw in some cases, while the financial part of the project is financed from national or EU funds, there are no financing opportunities for training of local actors to manage the project, write applications or offer technical support for project implementation.

- Encourage engagement within the community. Every project implemented should first of all prioritise local engagement. Outsourcing project-related activities also means outsourcing knowledge acquisition, innovation capacity and further project development. Hence, regardless of the project's goal, local-level engagement within every project activity should always be an underlying aim.

- Capitalise all existing local resources. As discussed previously, projects are rarely fit for specific local needs. This shortcoming should be addressed by looking at local resources in the first place. National and local authorities should first be encouraged to evaluate available local resources (natural, financial or human) and promote those initiatives or projects that rely more on local resources.

Local human capital must be a central priority for policy makers. By encouraging local knowledge and local engagement, we can promote increasing innovative capacity, wider public engagement and subsequent better usage of financial resources.

\section{Promote policy-making and programming at the local level}

The policy-making paradigm, as it is at the current moment, is hierarchic, with EU and national-level authorities designing the policies and the mechanisms to implement them. Regional or local actors are passive recipients of EU or governmental programmes with little to no say about them. As discussed in this chapter, while well intended a lot of these policies do not deliver the expected results; in some cases they even make existing discrepancies worse. This is hardly surprising since it is rather challenging to design policies in the central, metropolitan regions that would be effective and context-sensitive to remote, peripheralised localities. To address this issue, we believe that the current policy structure requires a series of changes. 
- Offer local communities the possibility to design and propose projects or programmes for implementation within the main policy framework that better fit their local needs and capacities. This could be accomplished by establishing a co-decision mechanism at the regional level and aggregating all proposals for a more targeted policy approach at the regional level or local level. In this way, local actors could become important within the national or even EU level policy-making framework.

- Allow for larger flexibility in fund usage at the local level through participative budgeting. Allowing local communities to get engaged at the financial management stage of the project, while also encouraging wide participation at the local level, could ensure higher levels of social capital and at the same time ensure a more effective way of spending the project money.

- Accept for consideration projects and proposals that go beyond the established framework. Given their peripheral location, small communities often need to reinvent themselves in order to attract and keep people. This assumes a different strategy than the one by the book,' so in this context, rural communities have to become innovative and creative in their own way. This can be ensured by investing in local educational activities and offering more tools for policy making and financial management to local actors.

It is important within the entire policy discourse that we change our way of communication. Remote, isolated and peripheralised local communities should not be viewed as 'subsidy requiring and dying places.' This understanding can be changed once we give local communities the possibility to become central in a different, alternative way. Only by starting with the movement of peripheries from the periphery at a conceptual level we can bring about de-peripheralisation processes.

Any successful policy approach to the problems of peripheralisation must consider the diversity of actors and institutions involved. Relying on this diversity and building on existing resources, the above five points could be used as a roadmap to ensure a structural approach is taken to address peripheralisation problems. 
Open Access This chapter is licensed under the terms of the Creative Commons Attribution 4.0 International License (http://creativecommons. org/licenses/by/4.0/), which permits use, sharing, adaptation, distribution and reproduction in any medium or format, as long as you give appropriate credit to the original author(s) and the source, provide a link to the Creative Commons license and indicate if changes were made.

The images or other third party material in this chapter are included in the chapter's Creative Commons license, unless indicated otherwise in a credit line to the material. If material is not included in the chapter's Creative Commons license and your intended use is not permitted by statutory regulation or exceeds the permitted use, you will need to obtain permission directly from the copyright holder. 